Evelyn Shea

Why work? 
Schriftenreihe des Max-Planck-Instituts für ausländisches und internationales Strafrecht

\section{Kriminologische Forschungsberichte}

Herausgegeben von Hans-Jörg Albrecht und Günther Kaiser

Band K 137 


\title{
Why work?
}

A Study of Prison Labour in England, France and Germany

\author{
Evelyn Shea
}

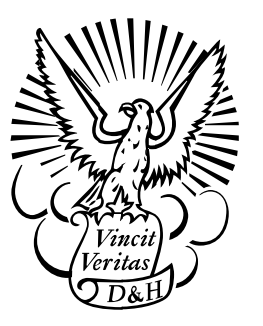

Duncker \& Humblot • Berlin 
Bibliografische Information der Deutschen Nationalbibliothek

Die Deutsche Nationalbibliothek verzeichnet diese Publikation in der Deutschen Nationalbibliografie; detaillierte bibliografische Daten sind im Internet über http://dnb.d-nb.de abrufbar.

DOI https://doi.org/10.30709/978-3-86113-086-4

\author{
Alle Rechte vorbehalten \\ (C) 2007 Max-Planck-Gesellschaft zur Förderung der Wissenschaften e.V. \\ c/o Max-Planck-Institut für ausländisches und internationales Strafrecht \\ Günterstalstraße 73, 79100 Freiburg i.Br. \\ http://www.mpicc.de \\ Vertrieb in Gemeinschaft mit Duncker \& Humblot GmbH, Berlin \\ http://www.duncker-humblot.de \\ Umschlagbild: Evelyn Shea
}

Druck: Stückle Druck und Verlag, Stückle-Straße 1, 77955 Ettenheim Printed in Germany

ISSN 1861-5937

ISBN 978-3-86113-086-4 (Max-Planck-Institut) ISBN 978-3-428-12689-7 (Duncker \& Humblot)

Gedruckt auf alterungsbeständigem (säurefreiem) Papier entsprechend ISO 9706 @ 
For my husband 



\section{Acknowledgments}

I wish to express my gratitude to the Max-Planck-Institute for Foreign and International Law (Freiburg, Germany) and its director, Prof. Hans-Jörg Albrecht, for their invaluable help in establishing contacts in Germany and for enabling me to use their outstanding library facilities. I am particularly grateful to Dr. Joachim Obergfell-Fuchs and Laura Pielmaier for their assistance with the statistical analysis of the questionnaires, to Michael Knecht for his meticulous editorial work and to Chris Murphy for his helpful suggestions. I am also indebted to the Centre de recherches sociologiques sur le droit et les institutions pénales (CESDIP, Paris) for facilitating the French part of my research, and to Dr. Pierre Victor Tournier for his advice and for putting me in touch with the English Prison Service and the Council of Europe.

Research of this nature cannot be done single-handed and I am grateful to more people than I can mention. I thank most warmly the French, German and English Prison Service headquarters and their Heads of work: without their help it would not have been possible to carry out the field work. My special thanks go to the governors of Ensisheim, Poissy, Montmédy, Schwalmstadt, Straubing, Kaisheim, Frankland, Featherstone and Swaleside, their workshop managers and industrial managers who gave generously of their time. Last but not least I wish to thank warmly all prisoners who answered the questionnaire and accepted to be interviewed. 



\section{Contents}

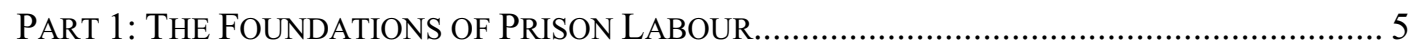

Chapter 1: The Aims of Work in Prison ................................................................................. 5

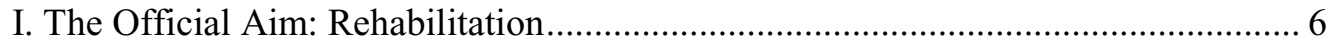

A. Increasing the employment skills of offenders: a means of

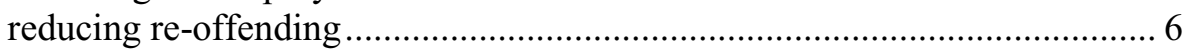

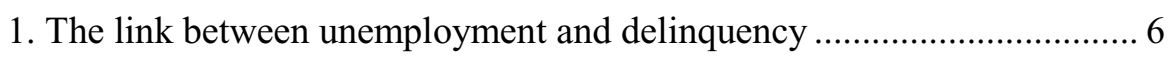

2. Professional handicaps of the inmate population ................................... 8

3. The role of work and training in prison to correct employment

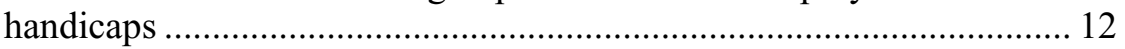

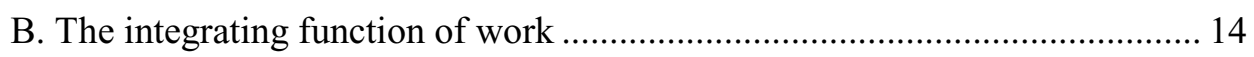

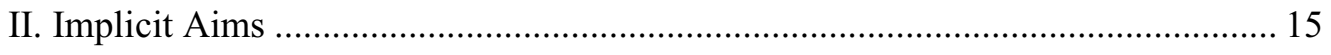

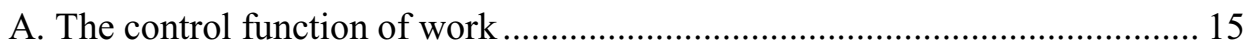

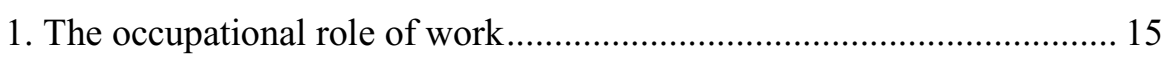

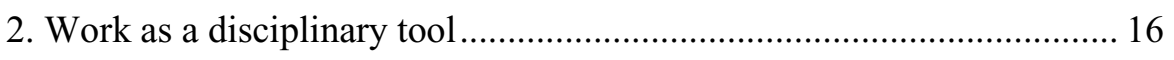

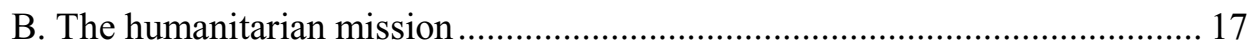

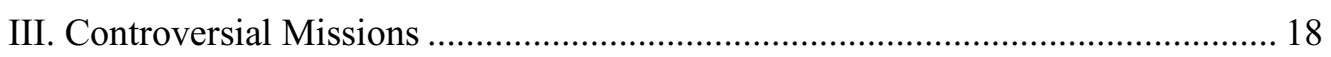

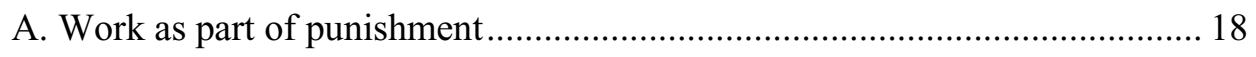

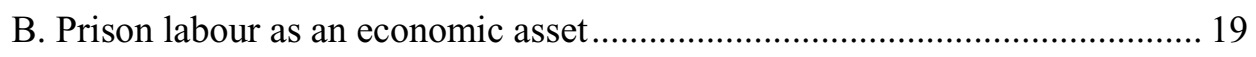

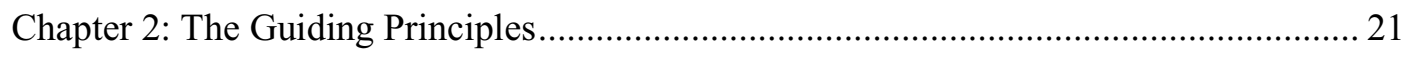

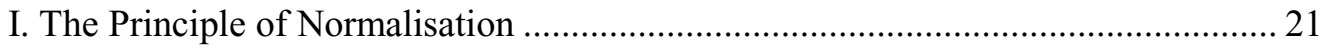

A. Normalisation of workers vs. normalisation of work ................................... 22

B. Different motivations, different results ......................................................... 23

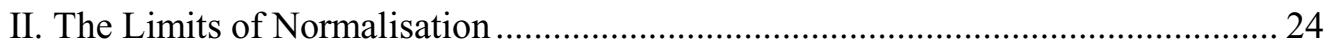

A. Limits imposed by the penitentiary system ............................................... 24

B. The principle of compensation as a limiting factor..................................... 25

C. The limits imposed by "less eligibility" ..................................................... 25

PART II: THE FRAMEWORK OF PRISON LABOUR …......................................................... 27

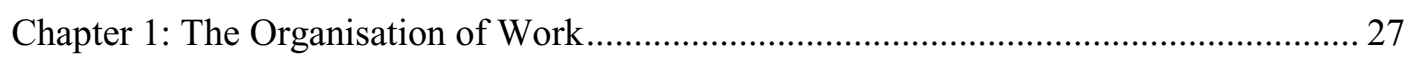

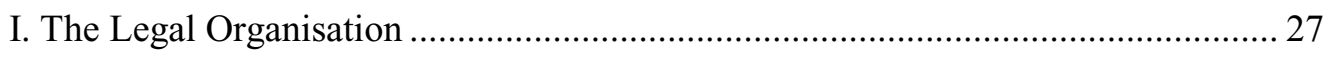

A. Work managed exclusively by the prison service.......................................... 27

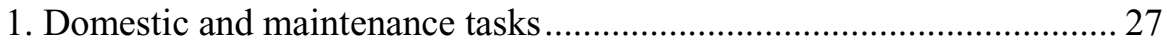

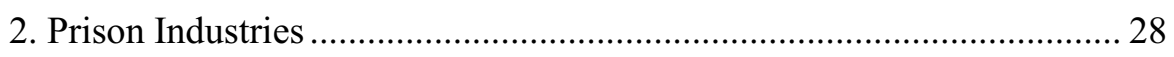

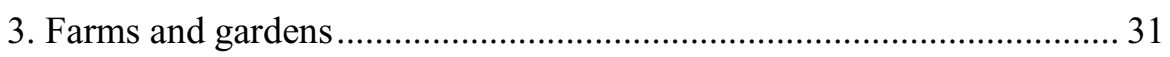


B. Work provided by external contractors, associations or trusts........................ 31

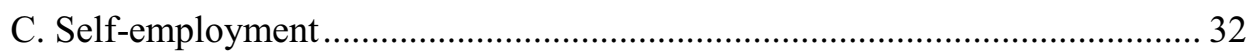

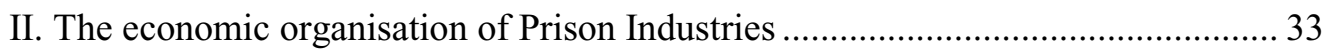

A. Workshop organisation and economic management ..................................... 33

1. The organisation of productive units ..................................................... 33

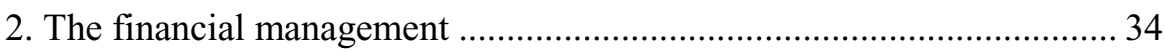

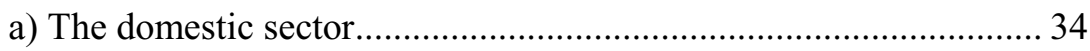

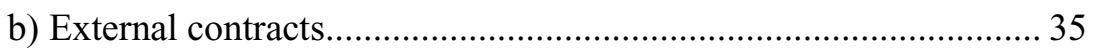

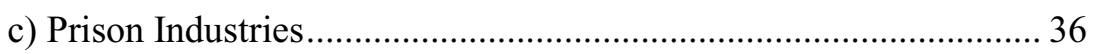

d) The overall economic performance of prison labour ...................... 37

B. Two key factors responsible for the lack of economic success...................... 39

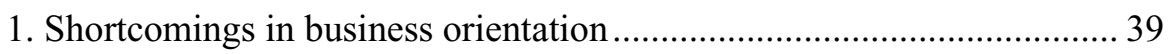

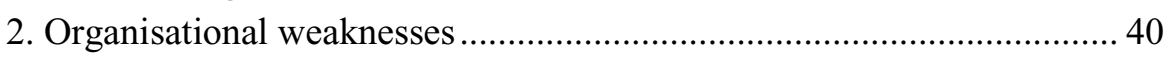

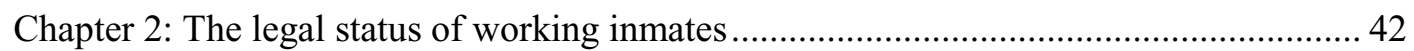

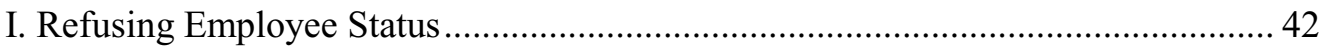

A. Arguments for and against excluding inmates from employee status........... 43

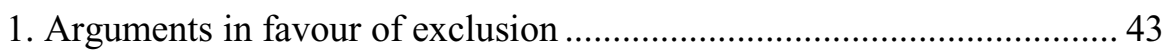

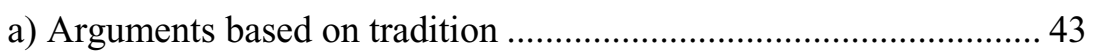

b) Arguments based on economic and security considerations.......... 43

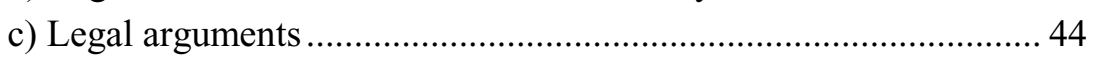

2. Arguments against exclusion.......................................................... 45

a) Employee status promotes rehabilitation ....................................... 45

b) Economic benefits......................................................................... 45

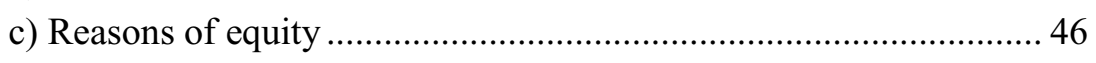

B. The consequences of the refusal of employee status ...................................... 46

1. Curtailment of rights and benefits ............................................................ 46

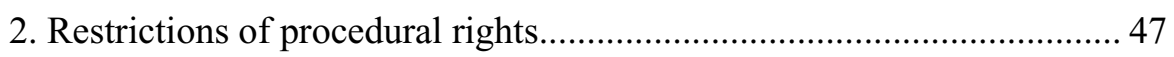

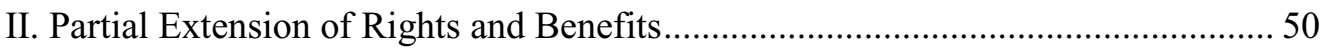

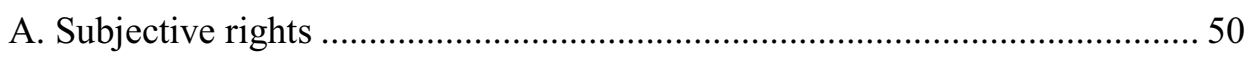

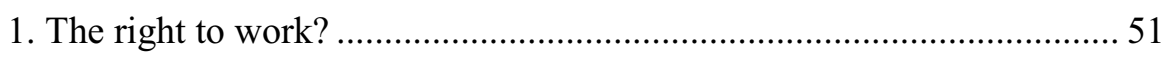

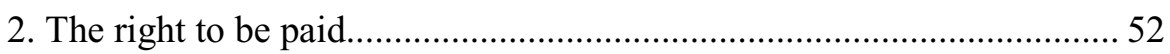

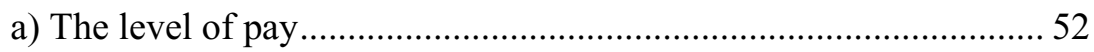

b) The basis of calculation ............................................................... 53

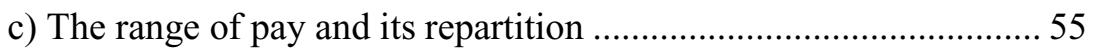

d) The notion of "appropriate wages" .................................................. 57

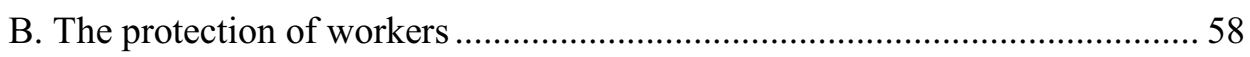

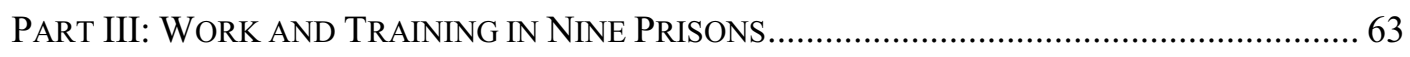

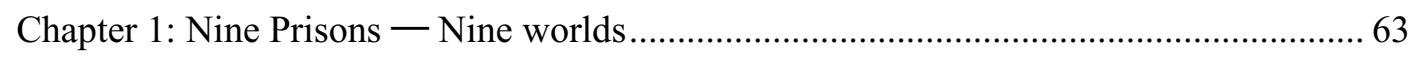

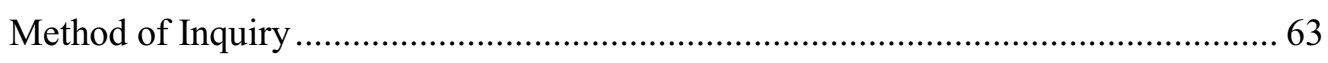

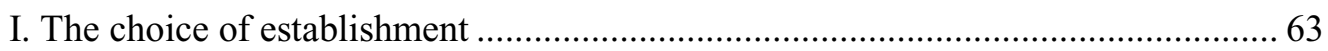




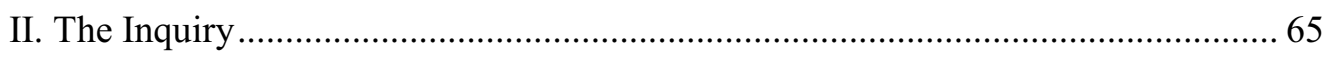

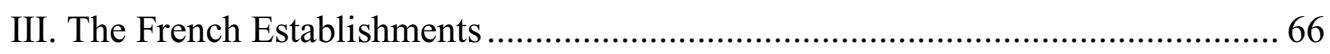

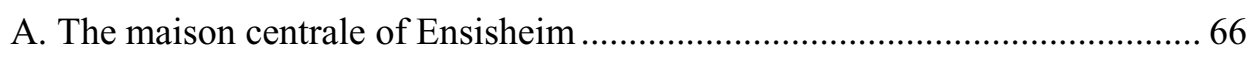

1. General information about the establishment .......................................... 66

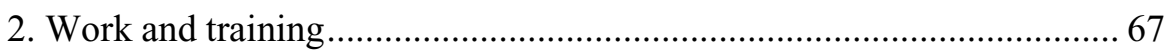

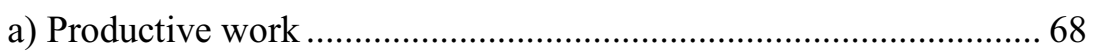

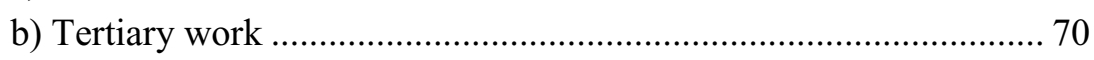

c) Housekeeping and maintenance duties ....................................... 70

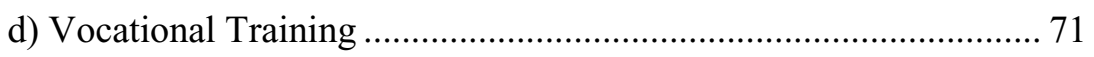

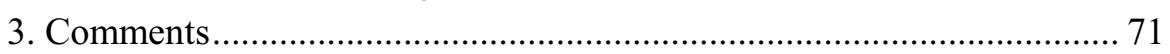

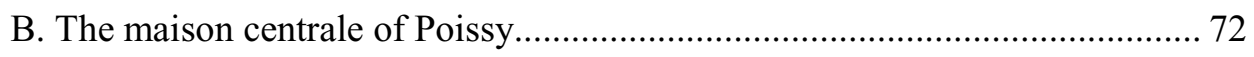

1. General information about the establishment ........................................ 72

2. Work and training......................................................................... 73

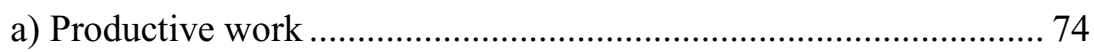

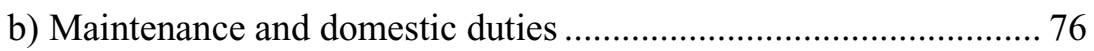

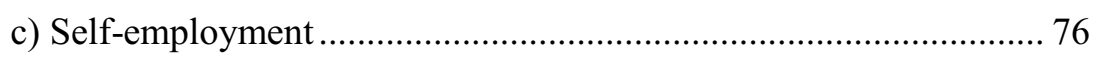

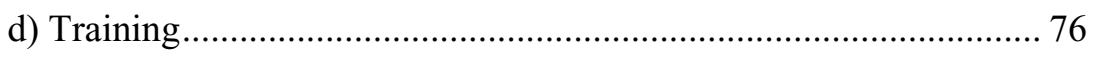

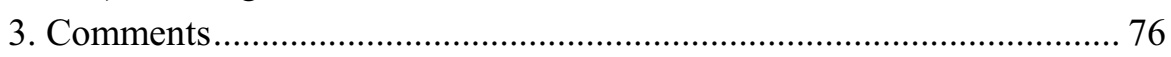

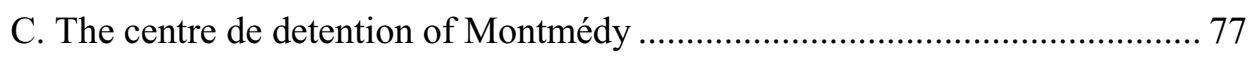

1. General information about the establishment ......................................... 77

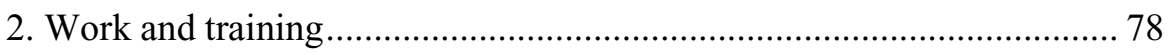

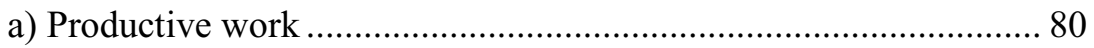

b) Domestic duties and maintenance................................................. 81

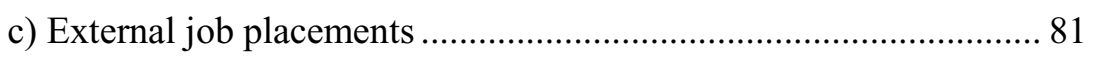

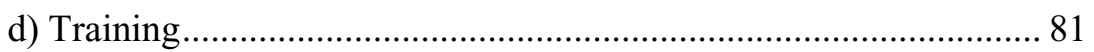

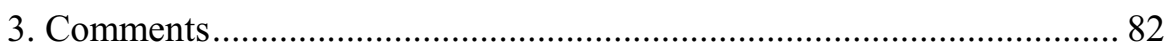

II. The German Prisons .................................................................................... 83

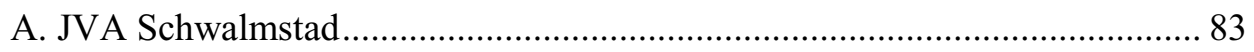

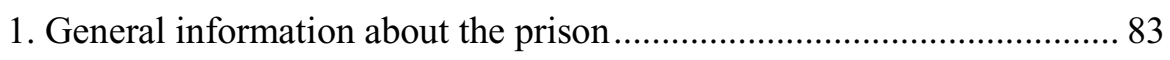

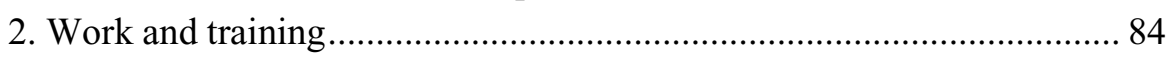

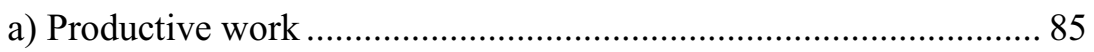

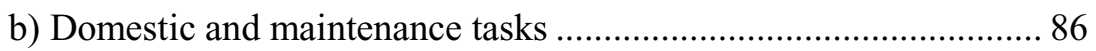

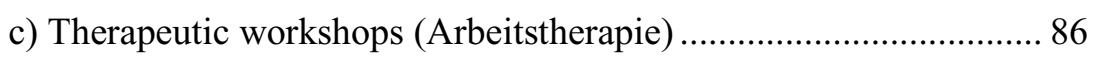

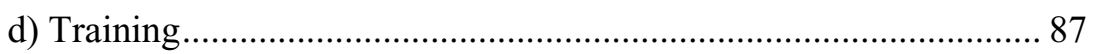

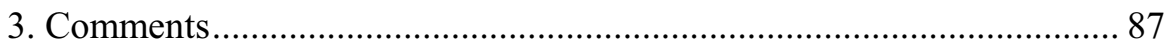

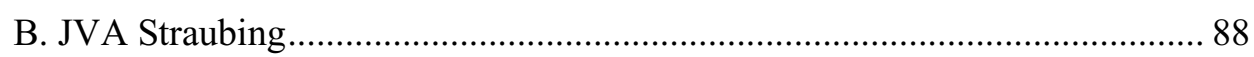

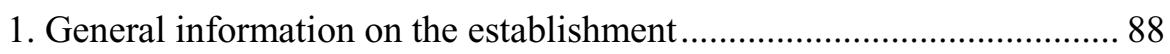

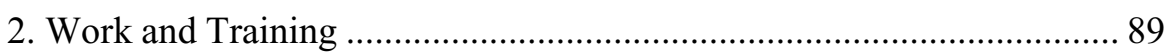

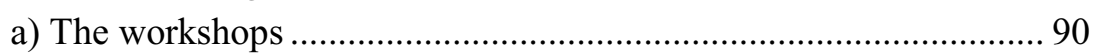

b) Domestic tasks, maintenance, laundry and kitchen ....................... 93

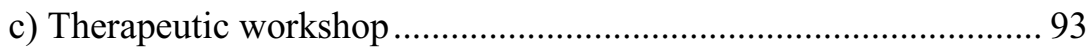

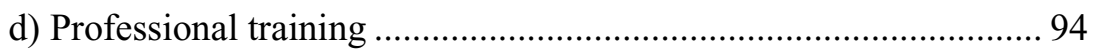




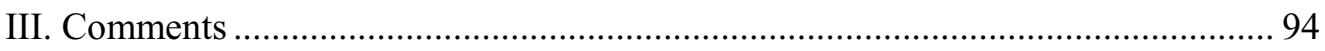

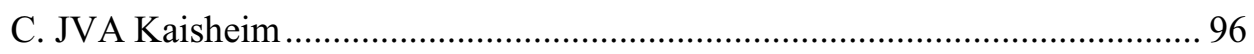

1. General information about the prison ................................................... 96

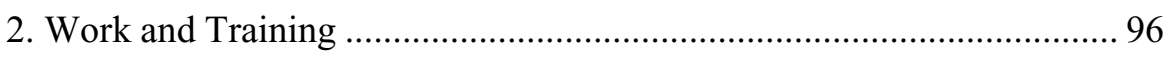

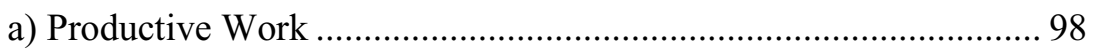

b) Domestic and maintenance work ……………............................... 100

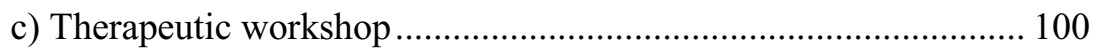

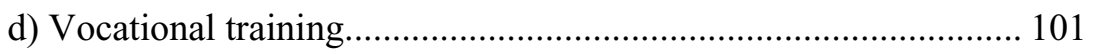

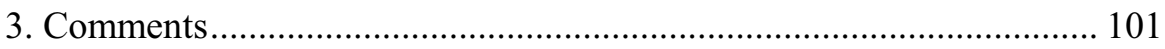

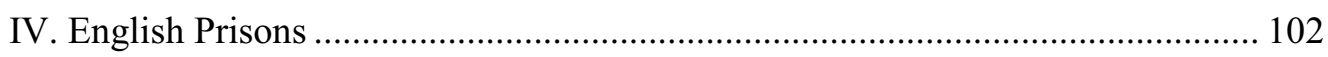

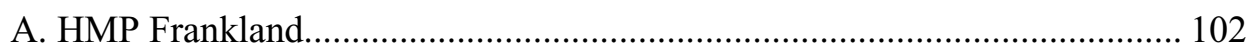

1. General information about the prison.................................................. 102

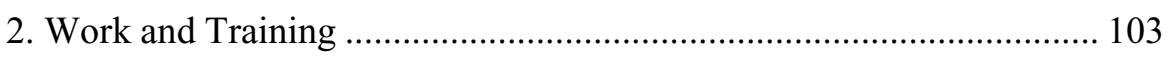

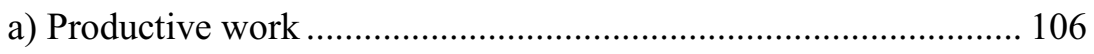

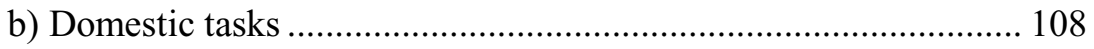

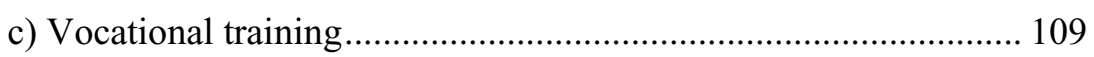

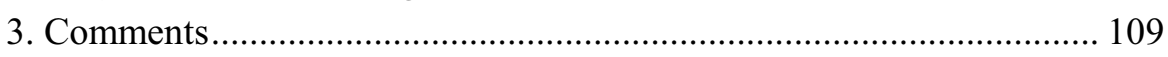

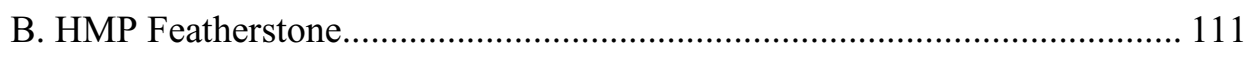

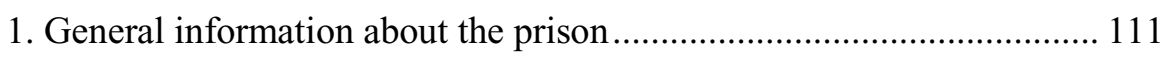

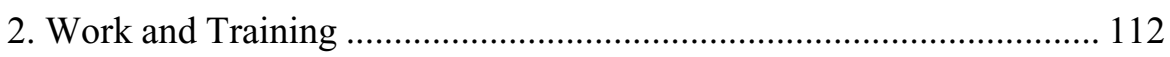

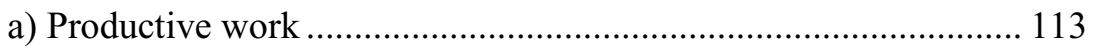

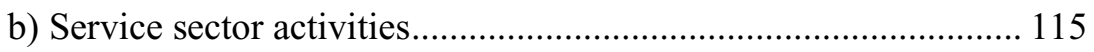

c) Domestic and maintenance tasks .................................................. 116

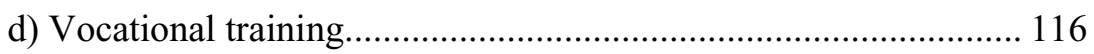

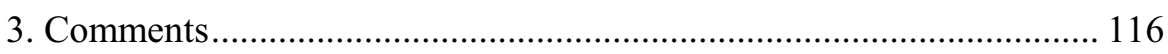

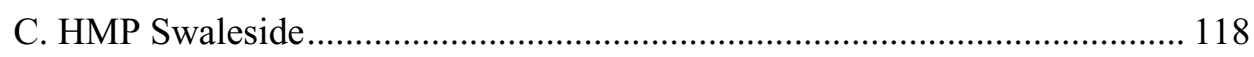

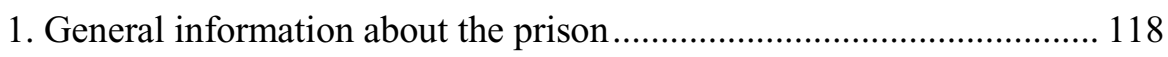

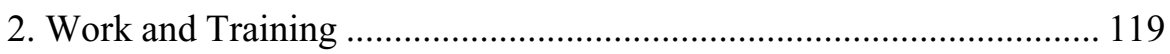

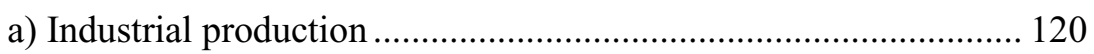

b) Domestic and maintenance jobs................................................. 122

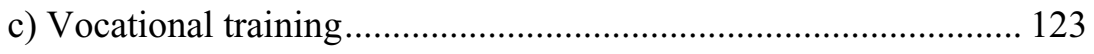

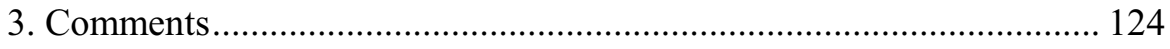

Chapter 2: Prison Labour Seen From the Inmates' Point of View .................................. 126

I. Previous Work Record and Actual Motivation .................................................... 126

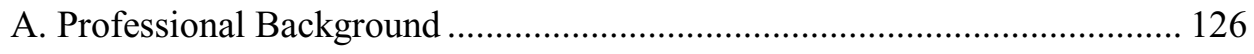

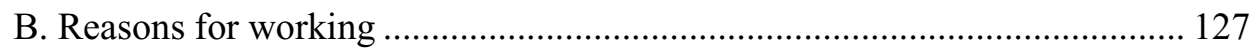

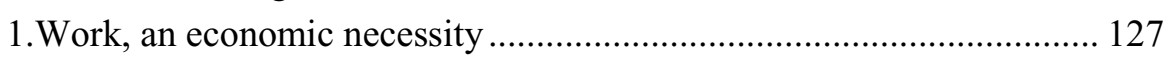

2. An activity that structures the day and gets inmates out of their cells . 128

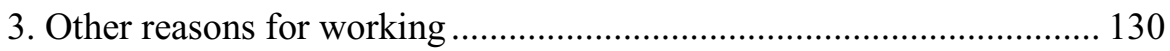

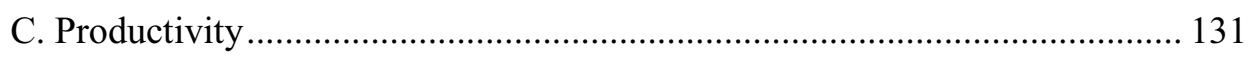

II. The Link between Work in Prison and Professional Reintegration .................... 132

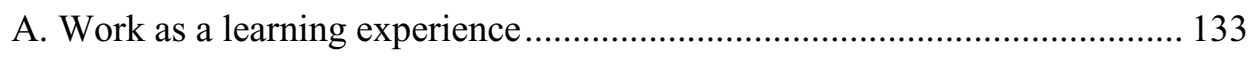


B. Expectations about a professional future ………......................................... 134

C. Prison labour as seen through the eyes of the unemployed........................... 137

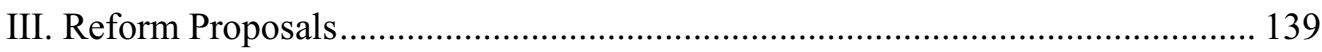

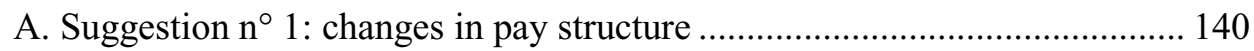

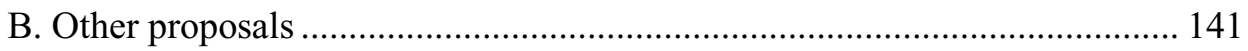

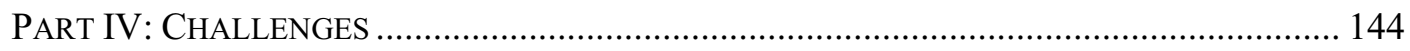

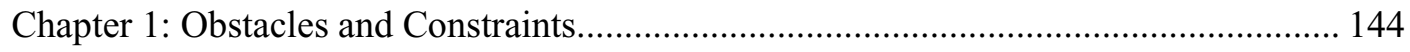

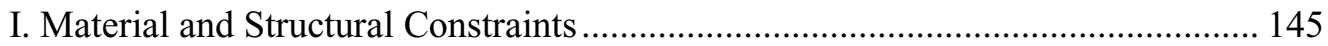

A. Unsuitable sites, premises and equipment …............................................... 145

1. Ill-adapted locations and premises ..................................................... 145

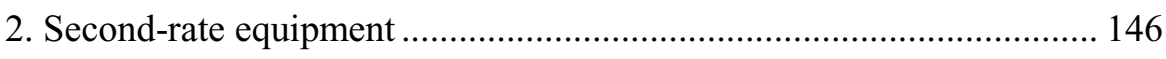

B. Constraints linked to the prison structure..................................................... 146

1. Rising prison population — rising security .......................................... 146

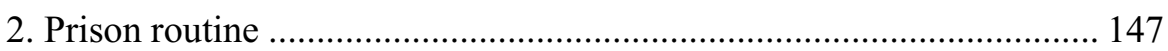

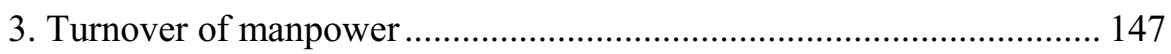

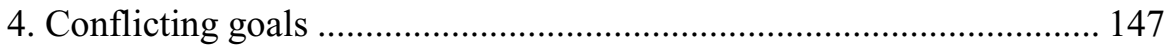

II. Constraints Linked to External Economic Transformations ................................ 148

A. Economic transformations have left Prison Industries behind...................... 148

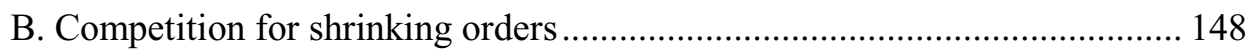

C. Work is suffering from a loss of status ..................................................... 149

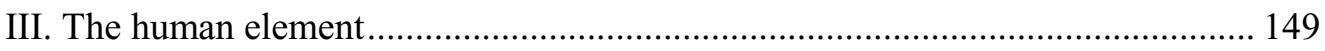

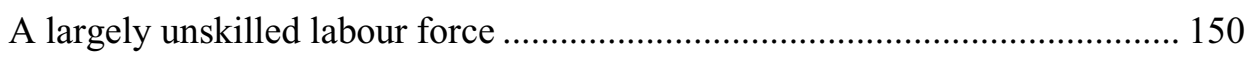

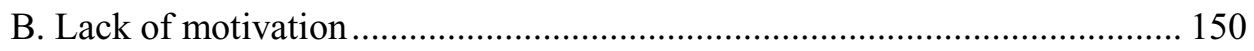

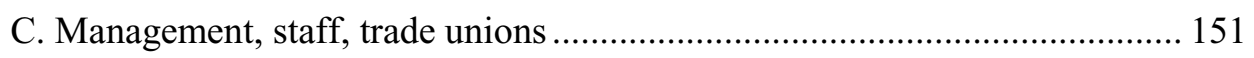

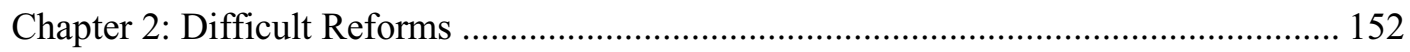

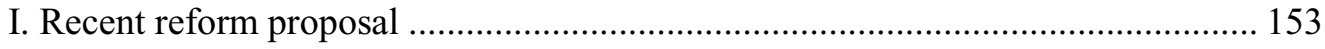

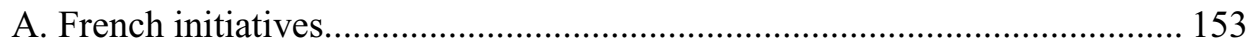

1. The projet de loi relatif au service public pénitentiaire (Bill pertaining to the public penitentiary service), adopted on $11^{\text {th }}$ June 1987 .

2. The report by the Social and Economic Council "Travail et prison", submitted by Jean Talandier in December 1987 ..................................... 153

3. Two three-year plans for the improvement of working conditions and the increase of the number of jobs .............................................. 154

4. Reforms proposed by the two parliamentary commissions of $2000 \ldots . . .155$

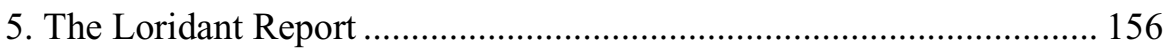

B. Reform programmes in Germany and England ............................................ 157

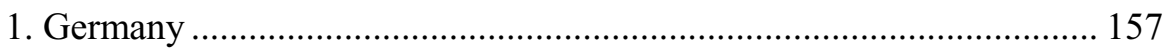

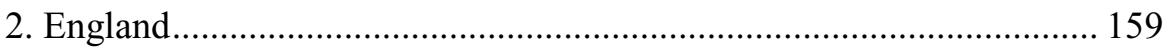

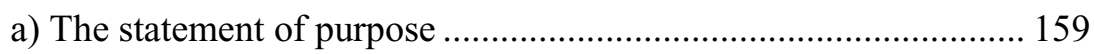


b) A clear division of competences ................................................. 161

c) Increasing the efficiency of Prison Industries ............................... 161

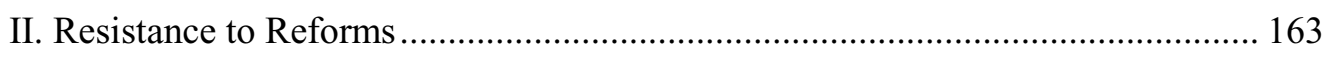

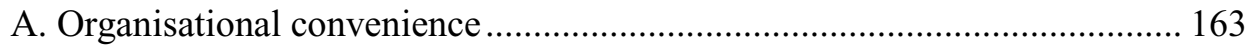

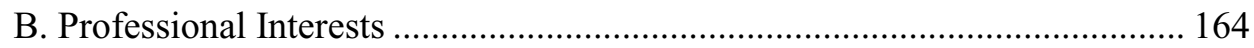

C. Political motivations and economic conditions............................................. 165

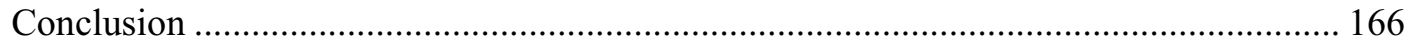

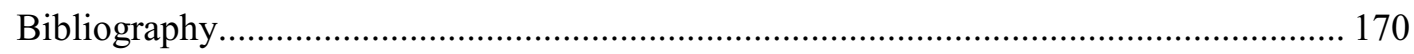

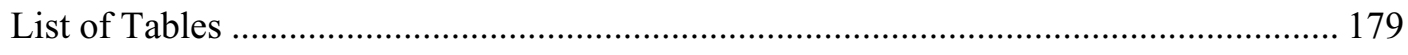

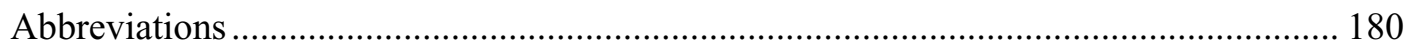




\section{Introduction}

Prison Labour: Salvation or Slavery? This title of a timely publication ${ }^{1}$ captures the problematic status of work in modern prison regimes. On the positive side, work seems a precious commodity for inmates and administrations alike. For prisoners, it provides a much needed source of income, training and work experience. It also creates a sense of community and gives meaning to a period of detention often experienced as time wasted. For the administration, prison labour holds the promise of reducing rising costs and keeping inmates busy and out of trouble. On the negative side, prison labour is linked to a long history of exploitation. For centuries, punishment took the form of hard labour: rowing galleys for the French kings, hauling heavy loads in shipyards, and being rented out as temporary slaves in far-away colonies. Working conditions in nineteenth-century prisons were no better to judge by the high death toll of working inmates, and were surpassed only by the abuse suffered by prisoners in the gulags and work camps of World War II.

But this is all past history. Today in the Western world, no inmate dies of malnutrition or exhaustion. Working conditions are generally adequate and bear comparison with outside standards. Work is no longer seen as a means of punishment but a window of opportunity toward rehabilitation. Nonetheless, the gap separating the prison workforce from free labour remains considerable: prisoners continue to work for a fraction of outside wages without the protections provided by an employment contract, and without job security. The tasks assigned to them, especially by outside firms, are no longer back-breaking but they are low-skilled, and of the kind salaried workers no longer perform. Slavery may be too strong a term, but the legal status of the inmate workforce is closer to that of illegal immigrant workers than we may care to admit.

Between 2001 and 2004, I carried out an inquiry in the light of several French parliamentary reports that were unanimous in their verdict that the "salvation" aspect of prison labour is in crisis. ${ }^{2}$ In its present form, work can, at best, alleviate the hardships of imprisonment and facilitate the control of the inmate population, but it no longer fulfils its main goal: to increase the employability of inmates and thus reduce recidivism. Four factors are held responsible:

1) A shortage of work and training places;

\footnotetext{
${ }^{1}$ Van Zyl Smit/Dünkel (1999).

2 Assemblée nationale (2000); Sénat (2000), Prisons: une humiliation; Sénat (2002), Rapport Loridant.
} 
2) A disproportionate number of low-skilled and mind-numbing jobs;

3) Unacceptably low pay levels; and

4) The absence of a sizable number of rights and protections that normally come with an employment contract.

The French parliamentary reports were also worried about the decreasing economic viability of Prison Industries which they blamed on inefficient organisation and management, globalisation, and the many restrictions imposed on workshops by security requirements.

What are the reasons for such an unsatisfactory state of affairs and what can be done about it? Is it only a French problem or is it common to other European countries? In order to answer these questions, I visited prisons in France, Germany and England because the size of their population, both in and out of prison, lent itself particularly well to a comparison. So too did the fact that all three countries want to reform prison labour but have quite different views concerning how to go about it.

The present book ${ }^{3}$ is divided into four parts. Part one deals with the legal framework of prison labour, its goals and guiding principles, the organisation and management of labour, and the legal status given to inmate workers. It provides some answers as to whether the legislation of the three countries is satisfactory for work to fulfil its missions. In parts two and three I consider the gulf that can separate law and practice. In the light of fieldwork in nine prisons, I compare the way legislation is implemented (part two) and how work is perceived by inmates (part three). Part four focuses on the constraints and difficulties with which prison labour has to contend, and discusses the reforms proposed by the three countries.

A thorough empirical study would have covered all regions of the countries concerned and would have included all types of prison establishments, but this was beyond my scope. I concentrated on three long-term prisons in each country, all of which receive male inmates sentenced to three years or more. ${ }^{4}$ If work is important for any inmate, regardless of the length of their stay, then it is crucial for those who face a long prison term. As a French inmate put it, "Without work you go crazy!" In the absence of regular employment and professional training, it is almost impossible for long-term inmates to make a successful professional comeback. Furthermore, from an economical point of view, it is only in long-term establishments that Prison Industries can develop their full potential.

3 An earlier version appeared in French as: Le travail pénitentiaire, un défi européen (2006).

4 The definition of what constitutes a long-term sentence varies from one country to another. The Council of Europe defines it as a sentence of five years or more. Strict adherence to this criterion of five years would have limited too severely the choice of establishments. 
To get as accurate a picture of prison labour as possible, I prepared a questionnaire that was handed out in English, French or German to roughly 20\% of the workforce. I also held semi-structured interviews with 90 inmates, and informal discussions with staff. I was able to observe the various workshops and other work places. The questionnaires and interviews helped me understand the expectations of the inmates, and conversations with members of staff, together with my observations, enabled me to assess the difficulties with which prison labour is confronted. As five years have passed between the English publication and the time I carried out my fieldwork, I have updated the information wherever possible.

The challenge of making work an effective instrument of rehabilitation is daunting. It calls for fundamental reforms and a reshuffling of priorities. Whether this challenge will be met depends to a large extent on the importance attached to work, both inside and after release. I hope that my research will convince the reader that work is crucial to rehabilitation. 



\section{Part 1: The Foundations of Prison Labour}

Before we can properly assess the performance of prison labour we have to answer two basic questions: What do we expect from work in prison? And what are the guiding principles that decide on its implementation?

\section{Chapter 1: The Aims of Work in Prison}

A business without clear goals is likely to head for disaster. The same holds true for prison labour. To spell out its purpose is all the more important since the laws regulating work in prison lack precision in this respect. The French Code of Criminal Procedure (Code de procédure pénale, CPP) simply states that "work performance is taken into account in the appreciation of progress made toward rehabilitation and good conduct" (Art. 717-3, al. 1). The English Prison Rules don't even touch on the subject, leaving it to briefings and internal reports. ${ }^{5}$ Only the German Prison Law ( $\$ 37$, Abs.1 Strafvollzugsgesetz. StVollzG) is more explicit and states that "work, therapeutic activities, vocational training and continued education serve in the first place to transmit, maintain and develop the necessary skills [for obtaining] a paid job upon leaving prison." But even this touches only on one aim, when there are several to be taken into consideration. Early on, inmate labour was also appreciated for its economic contribution to the prison; it proved an excellent tool for maintaining order and discipline; it could be used to increase the punitive aspect of the sentence, and it could also exercise a "humanitarian" role by giving the inmates an income and an occupation. These five functions have been present since the second half of the $18^{\text {th }}$ century, but the relative weight attributed to each of them has changed over time. The rehabilitative function of work, the last one to be recognized, is now the main official goal in all three countries. ${ }^{6}$ The importance of work for maintaining control as well as its humanitarian role is uncontested, but opinions are divided as to whether work should have a punitive component and

5 For instance: HM Prison Service, Briefings no. 51, July 1992, or Industries Review Team (2003), p. 4.

${ }^{6}$ The English position is not as clear-cut as in the other two countries. Whereas rule 3 of the Prison Rules points out rehabilitation as being the main goal of the prison regime as a whole, the latest recommendations of the Industries Review Team (2003, p. 16) seem to indicate that the control function and the occupational aspect of prison labour are just as important. 
whether it should aim to provide an economic contribution toward the cost of imprisonment. Functions we normally associate with our own work, such as subsistence, status, sociability or personal satisfaction, are vaguely included under rehabilitation or the humanitarian aspect of prison labour, but they are never more than a pale reflection of outside reality. Before trying to explain the reasons for this, I will examine the aims in turn, beginning with the most prominent: rehabilitation.

\section{The Official Aim: Rehabilitation}

There are two schools of thought on how work can contribute to the rehabilitation of inmates. The prevalent school considers regular work the best means of preparing inmates for future employment which, in turn, is seen as a key factor in reducing the risk of re-offending. The second school pursues the loftier goal of personal growth and social integration. From this viewpoint, workshops provide one of the few spaces within prison where inmates have a chance to change, because their individual effort and responsibility are valued, and traditional hierarchical structures do not necessarily apply.

\section{A. Increasing the employment skills of offenders: a means of reducing re-offending}

The prevention of re-offending is the key goal of Prison Services, and among the means at their disposal, work and training have traditionally been considered one of the most effective. The reasons offered are threefold:

1. There is a significant correlation between unemployment and delinquency;

2. Many offenders arrive in prison with multiple handicaps that hamper their future chances on the job market; and

3. The work and training offered in prison substantially contributes to reducing theses handicaps.

\section{The link between unemployment and delinquency}

Linking unemployment and delinquency is not new. Already at the end of the Middle Ages vagrants and beggars were put to hard work in the hope of turning them into useful citizens. But the connection has never been properly validated. Crow, Richardson, Riddington and Simon ${ }^{7}$ cite over thirty English and American studies that range from complete approval to complete denial. Albrecht, in his survey of German studies, points out the same contradictory results of studies in his

\footnotetext{
${ }^{7}$ Crow/Richardson/Riddington/Simon (1989), p. 4.
} 
part of the world. ${ }^{8}$ All we know for sure is that the number of unemployed among the new arrivals in prison is very high. In 2000, two-thirds of French and English prisoners were out of work the month before entering prison. ${ }^{9}$ The German statistics, quoted by Dünkel and van Zyl Smit ${ }^{10}$ show a similar range of 62 per cent to 73 per cent. Albrecht ${ }^{11}$ accounts for these statistics when he notes that unemployment, without being the only or direct cause, compounds existing social and personal deficits and thus increases the risk of delinquency. A criminal conviction will in turn multiply previous problems, among them difficulties related to obtaining work. Unemployment and delinquency thus have a reinforcing effect.

Thanks to two recent studies, one in Austria, the other in England, we now have precise figures on the employment status of two cohorts of inmates for the period before and after their imprisonment. In 1994, the Austrian researchers Hammerschick, Pilgram and Reisenfelder ${ }^{12}$ analyzed the work record of a cohort of 505 inmates during a six-year period: four years before their arrest and two years after release. During the first period, they noticed a steady decline in employment and an increasing distance from the labour market. The proportion of persons completely outside the network of social protections increased from 38 per cent in the first year to 50 per cent in the fourth year whereas the percentage of those having a relatively stable job decreased from 31 per cent to 20 per cent. The third group, which oscillated between periods of work and unemployment, was faced with growing stretches of inactivity: from 48 per cent in the beginning to 56 per cent in the twelve-month period before their arrest. It is true that during the same period (the early 1990s) Austria was going through difficult economic times and unemployment was generally on the rise. The authors conjecture that part of their sample was not able to cope with this more difficult context and that the delinquent act was in some way linked to the precariousness of their situation.

The English study of Frances Simon ${ }^{13}$ confirms the difficult employment situation of offenders during the period prior to their arrest. Of her sample of 178 inmates, 63 per cent were mainly or completely out of work during the 12 months prior to their offence, despite an educational level that should have given them better chances: 35 per cent were fully skilled (tradesperson, management or professional), 43 per cent semi-skilled, and only 21 per cent without qualifications. ${ }^{14}$

\footnotetext{
8 Albrecht (1988), BewHi 2, p. 133-147.

${ }^{9}$ Administration pénitentiaire (2002), p. 82; Social Exclusion Unit (July 2002), p. 20.

10 Dünkel/van Zyl Smit (1998), in: Albrecht/Dünkel/Kerner et al. (eds.), p. 1167-1172.

11 Albrecht (1988), BewHi 2, p. 146.

12 Hammerschick/Pilgram/Riesenfelder (1997), in: Hammerschick/Pilgram (eds.), p. 155-187.

13 Simon (1999), Prisoners' Work and Vocational Training.

14 Ibid., p. 231.
} 
The same link between unstable employment and offending can be observed after release: half the population studied by Hammerschink, Pilgram and Riesenfelder was reconvicted within two years, but only one third of those who had found steady employment were among these re-offenders. Simon's study provides similar evidence: five months after release, only 15 per cent of those who were working were reconvicted compared to 28 per cent, who were still looking for a job, and 75 per cent of those who did not apply for regular work. The two studies differ in one important point: in Simon's sample the people furthest removed from the network of social protections had the highest recidivism rate, but in the Hammerschick, Pilgram and Riesenfelder cohort, the group that wants to work but cannot find employment is the one that fares worse. This link between frustrated hopes and recidivism is also evident in a slightly older German study concerning young offenders: 85 per cent of those who left prison and whose job search remained unsuccessful returned to prison, even if they had received some training during their previous sentence, compared to 33 per cent of those who left with a diploma and found a job corresponding to their new qualifications. ${ }^{15}$ Their new status may have made desisting from crime easier.

What can we conclude from these findings? The statistical evidence leaves no room for doubt that the inmate population as a whole has a less stable employment pattern than the general population, given the six to ten times higher unemployment figures during the twelve months prior to incarceration. Recidivism statistics also show that those who manage to obtain regular work after release are less likely to return to prison. Why this should be so is less certain. Sampson and Laub's theory of informal social control ${ }^{16}$ suggests that social bonds, in particular family ties and employment, increase the level of desistance. It can also mean, as stressed by Albrecht, ${ }^{17}$ that unemployment reinforces existing social and personal deficits or perhaps simply that a person who manages to hold down a regular job already represents a positive selection. All we can affirm with certainty is the presence of a link between unemployment and delinquency but the fact of being without regular work is neither the only nor necessarily the direct cause of crime.

\section{Professional handicaps of the inmate population}

There is little doubt that a large number of inmates have handicaps that make it difficult for them to hold down a regular job. Many arrive in prison without professional qualifications and with little job experience, and a number also suffer from psychological or psychiatric problems or are in poor health. Work supervisors in all three countries agree that the situation has worsened over the last decade to the

\footnotetext{
15 Wirth, (1998), Prävention durch Wiedereingliederung, in: Kawamura/Helms (eds.). p. 66.

16 Sampson/Laub (1993).

17 Albrecht (1988), BewHi 2, p. 133-147.
} 
point that workshops are forced to turn down valuable contracts for want of qualified workers. The statistical evidence provided by the English Social Exclusion Unit in its report "Reducing re-offending by ex-prisoners"18 confirms the seriousness of the situation, as shown by the tables below:

Table 1: Level of education

\begin{tabular}{|l|l|l|}
\hline Characteristic & General population & Prisoners \\
\hline Left school at 16 or younger & $32 \%$ & $\begin{array}{l}89 \% \text { of men, } 84 \% \text { of } \\
\text { women }\end{array}$ \\
\hline Attended a special school & $1 \%$ & $\begin{array}{l}23 \% \text { of male, 11\% of fe- } \\
\text { male sentenced prisoners }\end{array}$ \\
\hline Have no qualifications & $15 \%$ & $\begin{array}{l}52 \% \text { of men, } 71 \% \text { of } \\
\text { women }\end{array}$ \\
\hline Numeracy at or below Level 1 (the & $23 \%$ & $65 \%$ \\
\hline level expected of an 11-year-old) & & $48 \%$ \\
\hline Writing ability at or below Level 1 & No direct comparison & $82 \%$ \\
\hline
\end{tabular}

Source: Report by the Social Exclusion Unit, p.19.

Table 2: Mental health

\begin{tabular}{|l|l|l|}
\hline Characteristic & General population & Prisoners \\
\hline Suffer from two or more mental disorders & $5 \%$ men & $72 \%$ men \\
& $2 \%$ women & $70 \%$ women \\
\hline $\begin{array}{l}\text { Suffer from three or more mental disor- } \\
\text { ders }\end{array}$ & $\begin{array}{l}1 \% \text { men } \\
0 \% \text { women }\end{array}$ & $\begin{array}{l}64 \% \text { men } \\
\text { Neurotic disorder }\end{array}$ \\
& $12 \%$ men & $40 \%$ men \\
\hline Psychotic disorder & $18 \%$ women & $63 \%$ women \\
& $5.4 \%$ men & $7 \%$ men \\
& $3.4 \%$ women & $14 \%$ women \\
\hline
\end{tabular}

18 Social Exclusion Unit (2002), Reducing re-offending by ex-prisoners. 


\begin{tabular}{|l|l|l|}
\hline Personality disorders & $\begin{array}{l}5.4 \% \text { men } \\
3.4 \% \text { women }\end{array}$ & $\begin{array}{l}64 \% \text { men } \\
50 \% \text { women }\end{array}$ \\
\hline Drug use in previous year & $13 \%$ men & $66 \%$ men \\
& $8 \%$ women & $55 \%$ women \\
\hline Hazardous drinking & $38 \%$ men & $63 \%$ men \\
& $15 \%$ women & $39 \%$ women \\
\hline
\end{tabular}

Source: Report by the Social Exclusion Unit, p.20.

Table 3: Physical health

\begin{tabular}{|l|l|l|}
\hline Characteristic & General population & Prisoners \\
\hline Long-standing illness or disability & $\begin{array}{l}29 \% \text { men aged } 18 \text { to } \\
49\end{array}$ & $\begin{array}{l}46 \% \text { of sentenced male } \\
\text { prisoners aged } 18 \text { to } 49\end{array}$ \\
\hline HIV & $\begin{array}{l}0.02 \% \text { of heterosexual } \\
0.25 \% \text { within London }\end{array}$ & $\begin{array}{l}0.3 \% \text { males } \\
1.2 \% \text { females }\end{array}$ \\
\hline Hepatitis & $0.3 \%$ Hepatitis B & $\begin{array}{l}8 \% \text { men, } 12 \% \text { women } \\
9 \% \text { men, } 11 \% \text { women } \\
\text { (Rates even higher } \\
\text { among intravenous drug } \\
\text { users: } 30 \% \text { men and } \\
34 \% \text { women })\end{array}$ \\
\hline
\end{tabular}

Source: Report by the Social Exclusion Unit, p.21

Inmates are not only disadvantaged as far as education and health is concerned, they also face a greater level of social exclusion.

Table 4: Factors contributing to social exclusion

\begin{tabular}{|l|c|l|}
\hline Characteristic & General population & Prisoners \\
\hline Regularly truant from school & $3 \%$ & $30 \%$ \\
\hline Excluded from school & $2 \%$ & $\begin{array}{l}49 \% \text { of male and } 33 \% \\
\text { of female sentenced } \\
\text { prisoners }\end{array}$ \\
\hline Ran away from home as a child & $11 \%$ & $\begin{array}{l}47 \% \text { of male and } 50 \% \\
\text { of female sentenced } \\
\text { prisoners }\end{array}$ \\
\hline
\end{tabular}




\begin{tabular}{|l|c|l|}
\hline Taken into care as a child & $2 \%$ & $27 \%$ \\
\hline $\begin{array}{l}\text { Has a family member convicted } \\
\text { of a criminal offence }\end{array}$ & $16 \%$ & $\begin{array}{l}43 \% \text { (35\% had actually } \\
\text { been in prison.) }\end{array}$ \\
\hline Debt & $\begin{array}{l}10 \% \text { of households with } \\
\text { difficult or multiple debts }\end{array}$ & $\begin{array}{l}48 \% \text { with a history of } \\
\text { debt }\end{array}$ \\
\hline
\end{tabular}

Source: Report by the Social Exclusion Unit, p.18-19.

French figures paint a similar picture. Two recent studies on the mental health of inmates show that 35 per cent were in psychiatric care before their arrest and that eight out of 10 suffered from at least one psychiatric problem: 39 per cent from depression, 31 per cent from general anxiety, 21 per cent from trauma related neurosis and 24 per cent from psychotic troubles. In category A and B prisons the percentage of inmates showing psychotic symptoms can be as high as 55 per cent. This is particularly disturbing as the percentage is almost 20 times higher than for the general population ( 2.8 per cent). As far as the level of education is concerned, 40 per cent of French inmates have a good level of education, the equivalent of an O-level leaving certificate or higher, but 50 per cent have not finished high school and 10 per cent are illiterate. ${ }^{19}$ In her study on poverty in prison, Anne-Marie Marchetti stresses the growing number of poverty related illnesses that interfere with regular employment, such as Aids or hepatitis B. ${ }^{20}$

The data available on German inmates is hardly more encouraging: 40 per cent of inmates have no school leaving certificate and maintain a negative attitude toward learning. 59 per cent have no recognized professional qualifications. Many lack key skills like punctuality, reliability, initiative or discipline needed to hold down a job or successfully complete training. 40 per cent of prisoners have a drug problem. ${ }^{21}$ In the late 1980 s the average inmate left prison with $€ 236$ and faced a debt of $€ 5000$. A few years later, the average debt rose to between $€ 12,500$ and $€ 22,500.22$

In short, our prisons receive many men and women who have experienced difficulties at school, at work and in their family life. A substantial number suffer from psychological and health problems. If nothing is done to correct these handicaps, their reintegration into the job market will be difficult if not impossible.

19 INSEE (2002), L'histoire familiale des hommes détenus.

${ }^{20}$ Marchetti (1997), p. 27.

21 Dünkel/van Zyl Smit (1998), Arbeit im Strafvollzug, internationaler Vergleich, p. 1167-1172; Hagemann (1995), MSchrKrim, p. 341f.; Matt (2003), , p. 82; Neu (1995), ZfStrVo, p. 149 f.; Radke (2001), ZfStrVo, p.10 f.

22 Bundesarbeitsgemeinschaft für Straffälligenhilfe (1993), p.174. 


\section{The role of work and training in prison to correct employment handicaps}

Is work and training in prison able to overcome or at least alleviate some of these obstacles to employment? The available employment statistics for ex-inmates provide no cause for optimism. The Austrian study of Hammerschick, Pilgram and Riesenfelder $^{23}$ shows that the twelve-month period after release is, from an employment point of view, even more disastrous than the twelve-month period prior to imprisonment. Only 16 per cent of inmates were able to find and keep a steady job for more than 6 months during the first year compared to 20 per cent before their arrest; 8 per cent got a subsidized contract or were in training; 15 per cent received unemployment benefits, and 61 per cent found themselves completely outside the social security network.

Table 5: Employment status of inmates before and after their prison term

\begin{tabular}{|l|r|r|r|r|r|c|}
\hline & $\begin{array}{l}4 \text { years } \\
\text { before }\end{array}$ & $\begin{array}{l}3 \text { years } \\
\text { before }\end{array}$ & $\begin{array}{l}2 \text { years } \\
\text { before }\end{array}$ & $\begin{array}{l}1 \text { year } \\
\text { before }\end{array}$ & $\begin{array}{l}1 \text { year } \\
\text { after }\end{array}$ & 2 years after \\
\hline $\begin{array}{l}\text { Working } \\
=>50 \% \text { per } \\
\text { year }\end{array}$ & $31 \%$ & $27 \%$ & $25 \%$ & $20 \%$ & $16 \%$ & $20 \%$ \\
\hline $\begin{array}{l}\text { Subsidized } \\
\text { contracts }\end{array}$ & $3 \%$ & $5 \%$ & $6 \%$ & $7 \%$ & $8 \%$ & $7 \%$ \\
\hline unemployed & $6 \%$ & $6 \%$ & $8 \%$ & $12 \%$ & $15 \%$ & $11 \%$ \\
\hline $\begin{array}{l}\text { No discer- } \\
\text { nible status }\end{array}$ & $8 \%$ & $8 \%$ & $8 \%$ & $8 \%$ & $9 \%$ & $4 \%$ \\
\hline OLF 24 & $53 \%$ & $54 \%$ & $53 \%$ & $53 \%$ & $52 \%$ & $58 \%$ \\
\hline Total & $100 \%$ & $100 \%$ & $100 \%$ & $100 \%$ & $100 \%$ & $100 \%$ \\
\hline
\end{tabular}

Source : Hammerschick/Pilgram/Riesenfelder (1997), p. 166.

During the second year, a small number managed to reach the former level of employment or improve on it, but the prospects for the majority were even more dismal than during the period immediately following release.

Simon's results are equally negative. Five months after release just 25 per cent of her sample had found relatively stable employment, 61 per cent were still search-

23 Hammerschick/Pilgram/Riesenfelder (1997), in: Hammerschick/Pilgram (eds.), p. $166 \mathrm{f}$.

24 Out of labour force: without indemnities and social benefits. 
ing, and 11 per cent had given up all together. The outlook was better for those who had already held a steady job before their prison term: half of them once again found permanent employment, and this was quite irrespective of whether or not they had worked in prison or had improved their qualifications. For the others, all measures taken inside to increase their employability seemed to have had no visible effect: only 13 per cent found a stable job. ${ }^{25}$

The employment figures of two other British studies are, if anything, worse: Mair and May found that only 21 per cent of offenders released on probation were able to find work, despite the help they were given by the probation service. ${ }^{26}$ This percentage decreased to 10 per cent for those who left prison at the end of their sentence. ${ }^{27}$ In short, there is little evidence to suggest that work and training in prison are an effective means to overcome the employment deficits of inmates.

How can we deal with this unwelcome conclusion? Would it not be best to openly admit that "nothing works" 28 and redirect the scarce resources of the Prison Service into more promising areas? Some administrations are moving in this direction. In 2006, the French Prison Service began cutting the small remuneration it used to pay inmates for participating in training programmes. At about the same time, the Dutch Prison Service decided to eliminate work and vocational training from its list of purposeful activities for inmates with short sentences ${ }^{29}$ and to replace them with educational or cognitive skills programmes. This may be the correct strategy for short-term prisoners, but hardly for the prison population as a whole, and this for two reasons. The first is that we don't know exactly why work and training fail to produce the desired results. If some authors are convinced that the undesirable side effects of imprisonment (loss of self-esteem, of initiative, of a sense of realistic expectations) and the difficulties encountered outside (debts, family problems, employer prejudice) are such that they inevitably undermine the positive effects of treatment, ${ }^{30}$ others are equally convinced that a better organisation

25 The percentages were calculated on the basis of the information provided by Simon (1999), p. 230.

26 Mair and May (1997), quoted in: Heddermann/Turnbull/Webster, Prison Service Journal p. 134.

27 Fletcher, Woodhill, Herrington et al. (1998), quoted in: Heddermann/ Turnbull/Webster, Prison Service Journal p. 134.

28 "Nothing works" was a popular slogan during the 1970s after the publication, in 1974, of a research paper by the American criminologist, Robert Martinson: What works? Questions and Answers about Prison Reform. The article seemed to indicate that the different forms of treatment available in prison and other rehabilitative measures had little effect on recidivism rates.

29 Four months or less.

30 Preusker (1988), ZfStrVo., p. 92-95, went as far as saying that it would be more charitable to prepare inmates for unemployment rather than for work after release. Garland (1998), Actes de la recherche en sciences sociales, p. 49-67; Liebling and Maruna (2005), p.4. 
and selection of activities would lead to a different outcome. ${ }^{31}$ The second reason is that the American experiment to replace treatment by so-called humane containment in reaction to "nothing works" has not been a success. ${ }^{32}$ Most inmates who answered our questionnaire failed to see the "humane" aspect of imprisonment if it meant spending long hours locked up without anything to do. Many are simply not interested in education or therapeutic programmes but want to work: 92 per cent said that they would rather have a dull job than none at all.

\section{B. The integrating function of work}

To reduce the rehabilitative mission of work to its strictly professional aspect may be aiming too low. Social inclusion means integrating inmates not only into a paid activity but allowing them to feel part of society and to open their way back to the community after release.

How can work contribute to the social integration of a person? It would go beyond the scope of this book to attempt a detailed account of the sociology of social integration. ${ }^{33}$ Let us just say that the concept implies an attempt to widen the circle of social inclusion by bringing in people who, for one reason or another, find themselves outside the protective network of an integrated social system. The function of integration is thus to assure them a recognized place in society that will allow them to "stand up straight" 34 and contribute to the common good. In traditional societies, this integration is automatic or "mechanical", to use Durkheim's term, whereas in modern societies, characterized by a greater diversity of values and functions, other means of integration must be found. One of these is work. Some authors even elevate work to the rank of chief integrator, 35 arguing that it has for the past four centuries become the guarantor of social cohesion, as work gives access to social status, plays an important part in shaping a person's identity, allows for social contact outside the family circle, and exercises a continuous socializing function. This concept of work may no longer be universally accepted, but it summarizes the expectations associated with it, even in prison. The problem is that employment, in order to fulfil its integrating mission, must meet certain conditions that are not often present inside the walls. Work assigned without the protections and guarantees of employment law, repetitive, mind-numbing tasks paid well below the rates fixed by collective agreements, and training and assistance that stop short the moment inmates leave prison are not likely to foster a sense of social inclusion. It is true that many jobs on the outside do not live up to expectations either, but free society offers compensating mechanisms, such as family, ethnic

31 All reports and most studies on prison labour.

32 For more details see: Kury (1999), in: Feuerhelm W.(ed.), p. 251-274.

33 See for instance: Loriol (ed.) (1999).

34 German Constitutional Court, BverfGE 98, 169.

35 Barel (1990), Connexions, p. 85-100. 
group or religious affiliation. In prison, such alternative integrators are greatly reduced, and it becomes in consequence even more important that work should be able to fulfil this function.

The rehabilitative mission of work in prison is thus clearly in jeopardy on two fronts: it is unable to remedy the professional handicaps of inmates and it contributes little to their social integration.

\section{Implicit Aims}

Even though most European prison laws name rehabilitation as the primary mission of prison labour, other functions may take on equal or even greater importance. Work has always played an essential part in controlling the inmate population, but it is also a key factor in making prison life more bearable.

\section{A. The control function of work}

\section{The occupational role of work}

"Thoroughly convinced that the hope of reforming criminals, that is turning them into honest men, is illusory, I cannot admit that work has an essentially reforming effect on them, but I believe that in every big prison work is the best warranty to ensure order and peace." This assessment of prison labour made by a governor of Clairvaux prison almost two hundred years ago ${ }^{36}$ may no longer be politically correct, but it may not be too far from the truth. Several of the workshop managers and prison officers interviewed held exactly the same views. There can be little doubt that work is a useful instrument to help maintain control for several reasons:

1. Of all activities available in prison, work reaches the greatest number of inmates. If there is any truth in the saying that idleness is the mother of vice, keeping prisoners busy at work prevents them from creating mischief.

2. During working hours, cell blocks become more easily manageable, as there are fewer inmates.

3. After several hours at work, inmates return to their cells tired, sometimes satisfied, and are less likely to cause problems.

4. Workshops have a pacifying influence on inmates. A French study by Guillonneau and Kensey concerning acts of aggression against staff shows that only 1.7

\footnotetext{
36 Statement by the director of Clairveau prison during an inquiry in 1834, quoted in O'Brien (1988), p. 196.
} 
per cent of incidents happen in workshops, compared with 45.8 per cent inside cells and 36.7 per cent in common rooms. ${ }^{37}$

5. The wages earned give access to consumer goods thus reducing some of the frustrations associated with prison life.

\section{Work as a disciplinary tool}

Granting or withholding employment is an effective means of ensuring good behaviour. The German Prison Law contains, for instance, a provision (§103, al.1, no.7) that allows for the suspension from work for up to four weeks for disciplinary incidents that are not work-related. We could hardly find a more convincing proof that work is no longer a punishment but a privilege! One of the prime worries of German inmates facing a disciplinary hearing is precisely the fear of losing their jobs. ${ }^{38}$ In England and France, suspension or dismissal is strictly linked to behaviour at work and cannot be used as a general disciplinary tool.

If the threat of losing ones job is the "stick" that ensures good behaviour, the promise of employment plays the role of the "carrot". A senior French prison officer put it plainly: "If I give an inmate a job as cleaner or orderly, he understands that I am doing him a favour and that he owes me something in return." This "something" may take the - very legitimate - form of expecting appropriate conduct, but it can also mean "providing information needed for the better management of the prison," in other words, information on other inmates. Such conditions are not only morally questionable; they also cast a shadow on the whole selection procedure and create resentment in those that remain without a job. To avoid this problem, the French Prison Service is putting in place in each prison an multidisciplinary selection committee composed of the head of work, a senior prison officer, a psychologist, a social worker, a teacher and, if needed, a medical doctor. We find the same kind of committee (Hauskonferenz) in Germany, but only for the assignation of domestic jobs. The selection of workshop candidates remains firmly in the hands of the head of work, as is the case in England. English prisons reserve a number of the most coveted jobs for inmates that have acquired enhanced status, i.e., who have given proof of consistent good behaviour. This status also gives them access to bigger cells, longer visiting hours and larger amounts of private cash. The notion that each privilege, even work, must be earned is thus much stronger than in the other two countries.

One might expect a good work record to play an important part in decisions on sentence adjustments, such as working-out permits or parole but, unfortunately, this

37 Guillonneau/Kensey (1998), p. 40.

38 See for instance: Schriever (2002), ZfStrVo, p. 87. 
is rarely the case. Hood and Shute, in their study on parole ${ }^{39}$ comment that work performance is only taken into account as a negative factor, such as when the parole candidate has been suspended or fired from his job. Other factors, especially the risk of recidivism, weigh more and push other considerations into the background.

\section{B. The humanitarian mission}

The "humanitarian" function of work - to use the term coined by French criminologist Bernard Bouloc - came to the forefront only after World War II but we find it already in the prison project of revolutionary France some 200 years earlier, when far-sighted members of the Constitutional Assembly proposed that prison labour should not be afflictive but instead allow inmates to better their condition and prepare for the time after release. ${ }^{40}$ Unfortunately, their motion did not carry the day. If work in nineteenth-century prisons allowed inmates "to better their condition," there was not much that was humanitarian about it. Without the extra food bought with their wages, prisoners simply would not have been able to get through a fourteen-hour workday.

Much of what the French philanthropists dreamt of has now been achieved: work is no longer part of punishment, it provides inmates with an income, and tries to prepare them for a professional future. Some would even argue that the "humanitarian" aspect of work is one of its most successful features. Many inmates, especially if their sentences are long, can no longer count on outside sources to provide them with private cash. Without work, they would not starve, but they would have to do without cigarettes, coffee, cookies and phone cards, not to mention "luxuries" like winter clothing or a PC. Having a job also means getting out of one's cell and having an activity that occupies and structures the day. It provides a place to be in company, without necessarily having to interact with the co-workers. For solitary or less adapted inmates this is an important aspect of work. During the interviews, the most frequent reason given for abandoning vocational training or classes was not lack of interest but relational problems with other inmates or staff. In a workshop, this is less of a problem.

Despite these positive features, there remains a certain malaise. It is true that work does give inmates access to consumer goods, gets them out of the isolation of their cells and structures their days. Under the best circumstances it can even be a source of satisfaction. But if we compare these benefits with the ones associated with outside jobs, they are but a poor shadow; some would even say a caricature. The average pay places inmates below the poverty line. It enables them to improve

39 Hood and Shute (1995), Paroling with New Criteria, Phase Two.

40 Bouloc (1991), p. 188-189. 
their daily lot, but is not enough to provide for their families, put away a release fund, or start reducing their debts. Work does occupy their time, but more often than not with dull jobs. As for giving meaning to time spent inside, only about ten per cent of jobs in England and France, and maybe twenty per cent in Germany offer intrinsic job satisfaction. Inmates are also not necessarily given the posts they are most suited for, as security considerations or organisational conveniences take priority. To embark on a career or, more modestly, to progress from a less skilled to a more demanding job or put into practice what one has learnt during vocational training is closely linked to professional satisfaction outside. In prison, such a progression is virtually non-existent. An inmate worker remains first of all an inmate, not a person with professional skills and aspirations. ${ }^{41}$

\section{Controversial Missions}

Two functions of work that were once at the forefront have been demoted to a more questionable status: the punitive aspect of work and its economic contribution to the cost of imprisonment.

\section{A. Work as part of punishment}

Should work be such as to increases the afflictive nature of imprisonment? The question may seem absurd. How can work be equated with punishment when more inmates want to work than there are jobs available and when work is part of treatment, and thus strictly separated from the punitive aspect of imprisonment? Yet, the practice of making offenders pay through hard and unpleasant tasks is difficult to abolish. Of course, no Prison Service today would openly advocate "work of the hardest and most servile kind, in which drudgery is chiefly required." 42 Still, because of "economic constraints" or "lack of alternatives" Prison Services are prepared to accept contracts for tasks that workers outside no longer perform, maintain wages at the lowest possible level, and keep the protection of employment law out of prison.

Prisoners are well aware of this aspect. Lord Justice Woolf and Judge Tumim, during their inquiry into the prison disturbances of April 1990, received a substantial number of letters from prisoners who characterized their work as "slave labour": monotonous, degrading and soul destroying. ${ }^{43}$ Several prisoners interviewed

\footnotetext{
41 See in particular: Legge (1978), British Journal of Criminology, p. 6-22.

421779 Penitentiary Act, quoted in: Simon (1999) p. 2.

43 Woolf /Tumim (1991), p. 389. (Hereafter referred to as the Woolf Report).
} 
in the present study couched their view in exactly the same terms, adding the low pay as an additional insult.

To give a few examples: In the 1990s, the English Prison Service was buzzing with projects to improve working conditions and to ease the transition to outside employment. ${ }^{44}$ The Prisoners Earnings Bill, which was to prepare the way for enhanced earnings in productive sectors, easily passed through Parliament and received Royal Assent in 1996. But in order for this act to become effective, certain changes to the Prison Law, accompanied by corresponding administrative instructions, were required. Ten years later, these changes still have not been made. In Germany, the Länder resisted for 24 years the implementation of a wage increase agreed upon in 1976. It was only under pressure from the Constitutional Court that an increase from 5 per cent to 9 per cent of a comparable outside salary was finally granted. The original project had aimed at 40 per cent. ${ }^{45}$ In France, the impetus created by two parliamentary reports on the (deplorable) state of French prisons at the turn of the $21^{\text {st }}$ century has petered out within three years, and the recommendations concerning prison labour have gone largely unheeded.

We could put it this way: in earlier times, drudgery was deliberate. Today, it is the result of indifference and insufficient funding. The result is not much more satisfactory.

\section{B. Prison labour as an economic asset}

Until the Second World War, the contribution made by prison labour toward the cost of imprisonment was generally accepted as one of its main purposes. This changed after the experience of the war, especially in Germany and France, where governments were anxious to dissociate compulsory labour from any suggestion of exploitation. The pendulum has recently swung back in favour of profitable Prison Industries. Confronted with rising costs and dwindling budgets, prison administrations increasingly look to prison labour as an additional source of income. Some German Länder like Baden-Württemberg or Lower Saxony have reorganised their Prison Industries into centralised, relatively autonomous units, the so-called Landesbetriebe vollzugliches Arbeitswesen, in order to boost their economic efficiency. The Loridant Report (2002) and the Report by the Industries Review Team (2003) both stress the need for greater business orientation in French and English Prison Industries.

44 For example, the Workshop Extension scheme and the Pathfinder project. Vagg/ Smartt (1999), in: van Zyl Smit/Dünkel (eds.), p. 63 f.

${ }^{45}$ For more detailed information see infra, part II, chap.2, II A 2a. 
There is no easy answer to the question of whether the renewed emphasis on the business aspect of Prison Industries is a positive development. Art. 72, al.2 of the European Prison Rules summarizes the advantages and the risks of a commercial approach:

Although the pursuit of financial profit from industries in the institutions can be valuable in raising standards and improving the quality and the relevance of training, the interest of the prisoners and of their treatment must not be subordinate to that purpose.

On the one hand, Prison Industries need to be run along commercial lines in order to maintain standards and working conditions close to outside norms. If they don't, they no longer provide appropriate training for inmate workers and risk losing contracts and hence jobs. It also seems fair that inmates, like other citizens, make a contribution to society through the income they generate. On the other hand, if the profit aspect becomes dominant, conflict with the rehabilitative mission of work is inevitable, particularly for an increasing number of inmates unable to adapt to the pace of commercially run workshops. These would have to be excluded from industrial work, relegated to domestic duties or left without activity. As this is the group that is most in need of having its employment skills upgraded, this is hardly a desirable strategy. The pressure to generate income may also induce prison administrations to accept contracts from outside firms irrespective of the quality of the work proposed. This temptation is especially strong in England, where governors are allowed to add part of the benefits from external contracts to the prison budget. Some European prison administrations, in Scotland and Ireland for example, have thus come to the conclusion that rehabilitation and commercially viable Prison Industries do not go together and have shifted the emphasis to training and general education. This may be too drastic a step considering that working in efficiently run workshops is, for a majority of inmates, still the preferred option.

However, recent attempts to bring Prison Industries in line with modern business practices may have less to do with income generation than with stemming the tide of unprofitable workshops. Despite the low wages paid to inmate workers, work shops, as a whole, have ceased to be profitable, and several operate at a loss. In 2002, the accounts of the French Prison Industries showed a small benefit of $€ 175,000$, but this was only possible thanks to a hidden subsidy of four million euros to cover the salaries of the workshop staff. ${ }^{46}$ In Germany, the situation varies from Land to Land. Whereas Bavaria and Lower Saxony claim that prison labour is still profitable, Hesse admits a net loss of $€ 3,658,327$ for 2001.47 According to the

\footnotetext{
46 Rapport Loridant (2002), p. 20.

${ }^{47}$ Hessisches Ministerium der Justiz (2002), Final report of the working group "Neuorganisation des Arbeitswesens".
} 
Report of the Industries Review Team for England, the net loss of Prison Industries for 2002 was estimated at $€ 13,212,727(£ 8,808,485){ }^{48}$

These are hardly encouraging facts, and the French Loridant Report is not far off the mark when it states that prison labour is in crisis, failing on two main fronts: rehabilitation and economic viability. Prison Services on the whole tend to downplay the urgency of the situation. Concerning professional integration, they argue that even the most menial job teaches inmates useful habits such as punctuality, constancy and industry. As for the disappointing economic figures, some administrators claim that "work is still a cheaper option than education, training or therapeutic programmes." It would be more profitable to face the facts and take an honest look at what prison labour does and does not achieve. We suggest doing so in the light of the guiding principles that we shall discuss in the next chapter.

\section{Chapter 2: The Guiding Principles}

Prison labour is subject to the same principles that structure prison regimes as a whole. The German Prison Law, which is more explicit than the others, lists four: 1. the principle of normalisation; 2. the principle of compensation (Gegensteuerungsprinzip); 3. the principle of rehabilitation; and 4. the principle of consent and cooperation on the inmates' part. ${ }^{49}$ For our purpose it is sufficient to consider the first two, as they encompass to a large extent the two others. ${ }^{50}$ All four principles aim at reducing the harmful effects of imprisonment and easing the return to society. However, there is an additional principle that should not be neglected: the principle of "less eligibility". We do not find it in any official text, but it is operative and blocks many promising reform projects.

\section{The Principle of Normalisation}

Normalisation, i.e., the attempt to render prison conditions as similar as possible to those outside, is now one of the basic tenets of incarceration. Prison labour is possibly the earliest example thereof and is often considered to be one of its most successful. I would disagree with this assessment as the only aspect of work in prison that come close to outside conditions are the production methods and, to a lesser extent, the human relations between supervisors and workers. The individual

\footnotetext{
48 Industries Review Team (2003), Annex E.

49 StVollzG, $\S 3$ et $\S 4$ (1).

50 The principle of rehabilitation implies that steps toward rehabilitation should be taken from the very beginning of the sentence, and this for all categories of inmates, even for true lifers. The principle of consent makes sure that these measures are not imposed by force and against the will of the prisoners.
} 
and collective rights that have been acquired by the workers over the last century have been carefully kept outside the walls.

\section{A. Normalisation of workers vs. normalisation of work}

Normalisation does not mean the same thing when applied to prisoners or prison conditions. In the first sense, normalisation is the leveling action that attempts to bring the behaviour of inmates in line with societal expectations. This has been strongly criticized by the French philosopher Foucault ${ }^{51}$ as a means of dressage, unworthy of a civilized society. Foucault may have exaggerated the leveling passion of the Prison Services and overestimated the disciplinary means at their disposal, yet the hope of inculcating "good habits" through work is profoundly enshrined in the mind of prison staff.

When normalisation is applied to living conditions, the aim remains to reduce reoffending, but the strategy is entirely different. Instead of imposing a standardised behaviour, Prison Services try to create "conditions that will allow inmates to return to society without further conflict with the law and the criminal justice system." 52 When the prison moves away from the totalitarian structure described by Goffman $^{53}$ and reflects the standards of civil life, chances for rehabilitation are deemed to improve. It is in this sense that normalisation is defined by the German Prison Law: "Life in prison should resemble as closely as possible the general living conditions outside." 54 English and French texts contain similar provisions, but they apply them exclusively to prison labour. Art. D. 102, al. 2 of the Code de procedure pénale stipulates that "the organisation, the methods and the pay scale should resemble as closely as possible those of professional activities outside, in order to prepare inmates for normal working conditions [after release]." A Prison Service HQ policy statement issued to governors in 1992 assesses prison work according to the degree of normalisation achieved.

${ }^{51}$ Foucault (1975), Surveiller et punir. In particular chapters III and IV.

52 Snacken (2002). In De Schutter/Kaminski (eds.), p.134.

53 Erving Goffman, in his pioneering study "Asylums" (1961) defines as total institutions organisation such as monasteries, asylums or prisons where: All aspects of daily life are restricted to the same place and are strictly regulated. The members lose their prior identity to take on a new one, that of the delinquent, the insane or the monk. This transformation of identity is accompanied and achieved by a system of humiliation and reinforced by an infantilizing regime that precludes taking responsibility either for oneself or for one's family. Everything is forbidden that is not explicitly allowed. The law is replaced by a system of privileges and punishments.

54 "Das Leben im Vollzug soll den allgemeinen Lebensverhältnissen soweit als möglich angeglichen werden." (StVollzG § 3 (1). 
Is the work experience realistic compared with that likely to be found outside, in terms of acceptance of responsibility; hours of attendance; production process/technology, interaction with others (supervisors, workmates); incentives for good work/penalties for poor performance; chances of the inmate getting that kind of job outside; pace of work ${ }^{55}$

In short: although of the two meanings of normalisation only the second has found a place in official texts, the hope of turning inmates into reliable, industrious workers is nonetheless present in prison.

\section{B. Different motivations, different results}

The drive to bring prison conditions more in line with outside standards is relatively recent. It is only since 1975 that French inmates have been allowed to wear their own clothes. In 1983 they were allowed to watch TV in their cells, and in 2005 the so-called "family parlours" were introduced on an experimental basis. These measures were intended to render prison more humane and to limit its punitive aspects to the deprivation of liberty.

The origins of the normalisation of prison labour date back much further. Already in the early $19^{\text {th }}$ century, French prisoners in the shipyards worked side by side with skilled free workers at the same tasks and at the same pace, and prison manufactures did their best to copy the production style of proper factories. The motivation behind this had little to do with prisoners' welfare, quite the contrary; the sole aim was to increase productivity. Working conditions were thus "overnormalised", i.e., inmates were made to work longer hours and at a faster pace than free labour, with normalisation being limited to production methods and workshop organisation. This is to a large extent still the case today, but with a strange inversion: since there is no longer enough work to keep a growing inmate population busy, we now have "under-normalisation", in the sense that the demands made on inmate workers have become less stringent than those outside.

The wish to turn prisons into more humane places has nevertheless led many European countries, such as France and Germany, to extend the concept to other aspects of work, in particular to the area of social benefits, but the majority of measures provided by modern employment law to protect the interests of workers are excluded, leaving inmates vulnerable and limiting the rehabilitative effect of work. ${ }^{56}$

In order to be an efficient tool of professional and social rehabilitation, work has to fulfil certain minimal standards of normalisation, namely it should:

\footnotetext{
55 Quoted in Simon (1999), p. 16.

56 For more details see the excellent German monograph by W. Lesting (1988), Normalisierung im Strafvollzug, p. $6 \mathrm{f}$.
} 
1) Reproduce the management and organisation of outside workshops as far as hours, pace and quality of work and equipment is concerned;

2) Offer a variety of jobs that correspond to available jobs outside and leave room for the different skills and interests of a heterogeneous workforce.

3) Base the salaries on corresponding collective agreements, with adjustments for the lower productivity levels in prison.

4) Apply the provisions of employment law and the corresponding social legislation, as long as these do not pose an unacceptable risk to the order and safety of the prison or to the viability of workshops.

We are still far from this ideal. If working conditions pass the test as far as pace and quality of production are concerned, the situation is less satisfactory concerning the hours worked or the quality of equipment. As for the variety of jobs and the application of employment law, "normalisation" can hardly be spoken of. Even the business organisation of workshops is often not up to standard. "If businesses were run on the same lines as ours, they would have gone bust a long time ago." This comment, heard from both staff and inmates, sums up the state of affairs in many workshops.

\section{The Limits of Normalisation}

Why is it then that normalisation proceeds more slowly for work than for other aspects of prison life? Three reasons can be offered: 1) limits imposed by the penitentiary system; 2) problems linked to the workforce; and 3) the old maxim that inmates should not have it better than "honest folks".

\section{A. Limits imposed by the penitentiary system}

Prison routine and security concerns have had a dampening effect on attempts to expand the field of normalisation. They are responsible for restricted working hours, the constraints faced by external contractors, and the impossibility of granting collective rights to workers. Budgetary limitations and the rigidities of the prison officers' union are other stumbling blocks. So is the refusal of judges to ensure its implementation.

Lesting, in his study of normalisation, examined all court decisions explicitly dealing with normalisation in 24 German criminal jurisdictions. He found 57 in all. Compared to the total number of cases, this is a very small number, at the most 2 per cent. ${ }^{57}$ Judges did not extend the principle to cases where it was clearly appli-

57 Ibid. p. 81. 
cable and tended to defend the absence of normalised practices with vague justifications such as "administrative necessities" or "the particular context of imprisonment." 58 Instead of correcting outdated practices, the judges thus anchored them even more solidly. Lesting's research was carried out almost 20 years ago and the German judicial practice may have evolved since, but we are not overly optimistic, as Richardson and Herzog-Evans note the same problem in England and France. ${ }^{59}$

\section{B. The principle of compensation as a limiting factor}

As a rule, when living and working conditions in prison resemble those of society at large, the harmful effects of imprisonment are reduced. But in certain cases, the egalitarian application of outside standards does not meet the needs of already disadvantaged groups. If competitive and efficiently managed workshops are good for those inmates that can keep up the pace, they are less suited for the growing number of prisoners who, already on the outside, could not be integrated into a normal work pattern. The German Prison Law ( $\$ 37$, al.5) thus proposes the institution of therapeutic workshops and, in France, there are talks about implementing preparatory workshops for those who cannot be directly employed in production. Neither attempt has so far produced the expected results: the number of places offered in therapeutic workshops remains symbolic, and plans for preparatory workshops have not gone beyond the project stage.

\section{The limits imposed by "less eligibility"}

The restrictions imposed by the principle of compensation are motivated by a desire to improve the professional outlook of inmates. The same cannot be said of another principle, less openly evoked but none the less effective: the principle of "less eligibility", based on the conviction that a prison sentence will lose its deterrent effect, if life inside is not made more unpleasant than that of the poorest segment of society outside.

We find the first official formulation of the principle in the English Poor Law Amendment Act of 1834 meant to limit the growing number of welfare claimants. 60 The concept of "less eligibility" is much older, however, and has been part of

58 Ibid. p. 84.

59 Richardson (1994), in: Player/Jenkins (eds.), p. 205. Herzog-Evans (2002), in: de Schutter/Kaminski (eds.), p. $22 \mathrm{f}$.

${ }^{60}$ An Act for the Amendment and better Administration of the Laws relating to the Poor in England and Wales (4\&5 Will IV c.76). 
penal and social policies since antiquity. ${ }^{61}$ It has often been criticized as inhumane and counterproductive, even from such an unlikely source as the French king Louis XVI who tried to soften the lot of convicts working in the arsenals. The best-known English exponents are the founders of the Fabian Society, Sidney and Beatrice Webb and their friend George Bernard Shaw. The Webbs, in their study on English prisons, were the first to apply the principle explicitly to the penitentiary. ${ }^{62} \mathrm{~A}$ few years later, the German sociologist, Georg Rusche, took up the topic in his essay Arbeitsmarkt und Strafvollzug, ${ }^{63}$ and provided a concrete definition of the "lowest socially relevant proletarian strata." In the Germany, these were no longer the poor in general, the great mass of the unemployed, but those that fell through the meshes of the protective network of social insurance. Today they are represented by illegal immigrants, the homeless and other marginal persons who do not figure in the statistics of people in need. Among them is a sizable proportion of inmates. 50\% of the sample of Hammerschick, Pilgram and Riesenfelder were not covered by any form of government assistance or insurance the year before their arrest. ${ }^{64}$

The negative impact of "less eligibility" is seen in the low pay, the unskilled and repetitive nature of most jobs, and the deliberate exclusion of employment law. What is less obvious is the motivation behind it. Why do reports of work inspectors disappear in some drawer, and why do governors sign external contracts that have no professional value? This can hardly be to dissuade inmates from returning to prison by making their life more unpleasant, but because other priorities are more pressing and the prisoners pay the price. The same applies to the lack of protections and rights provided by employment law. When half the inmate population has never worked with a proper contract of employment, the fact that they are not given one inside prison is unlikely to help them mend their ways. Most inmates do not wish to return to prison whatever the conditions. Motivation may thus have shifted away from deterrence, but "less eligibility" is as strong as ever, and remains one of the most powerful obstacles to reform.

Having outlined the aims of prison labour and the principles that guide its implementation, we now turn, in part II, to its legal framework.

61 For more detailed information on "less eligibility" see: Feest (1999), Punishment and Society, vol. 1; Melossi (1978), Crime and Social Justice; Introduction of Lévy/Zander (1994), in: Rusche/Kirchheimer; Sparks (1996), in: Matthews/Francis (eds.).

62 Webb/Webb (1922), English Prisons und Local Government.

63 Published in: Zeitschrift für Sozialforschung, Jahrgang II/1933, Frankfurt. Rusche was at the time a member of the Institut für Sozialforschung of the Frankfurt School. 166.

64 Hammerschick/Pilgram/Riesenfelder (1997), in: Hammerschick/Pilgram (eds.), p. 


\section{Part II: The Framework of Prison Labour}

\section{Chapter 1: The Organisation of Work \\ I. The Legal Organisation}

In England, France and Germany prison labour is organised along one of three lines: direct management by the prison; management through external contractors or associations; self-employment.

\section{A. Work managed exclusively by the prison service}

Direct management of work by prison staff takes two forms: organising and supervising domestic activities, and managing production workshops, farms and gardens.

\section{Domestic and maintenance tasks}

Prisons can function without workshops, but no prison can do without the services provided by its domestic and maintenance staff: cooks, laundry workers, cleaners, electricians, painters, gardeners, barbers, servers, librarians, even scribes. There is little difference between these jobs in the three countries, and their organisation is virtually identical. The differences in the legal texts are also of little practical importance. The French Prison Law stipulates that "in each prison, inmates are assigned to housekeeping duties. [...] The inmates are preferably chosen among those who do not have to serve a long sentence." (Art. D. 105, al 1 and 2, CPP). The German text ( $\$ 41$, al. 1 StVollzG) adds a time limit: "[The inmate] can be held to perform domestic services for a period of 3 months per year. With his consent, this period can be extended." The English Prison Rules do not refer to this topic, but the Woolf Report contains the similar recommendation that domestic duties be restricted to short periods. ${ }^{65}$ In reality, the shortage of work places in industry leaves inmates little choice but to hang on to their service jobs until a better option becomes available.

65 Woolf/Tumim (1991), p. 388-389. 
France has recently made a considerable effort to modernise the domestic sector and to link it with training options. ${ }^{66}$ Clear job descriptions and performance indicators have been introduced for three categories of tasks, the average pay has been increased by 25 per cent, and officers are trained to take on the role of tutors to prepare inmates for more qualified work.

Germany has a five-tiered classification system for all jobs, domestic and industrial. ${ }^{67}$ Most domestic occupations fall in the lowest category. In common with England, housekeeping also comprises commercial units, such as laundry, butchery, bakery and catering. In both countries, candidates for these latter units are usually chosen by the industrial manager and his team, whereas the cleaning and orderly jobs are assigned by the wing staff or, in Germany, the wing conference (Hauskonferenz).

Despite these minor differences, common elements prevail. The majority of tasks require little skill and correspond to the needs of inmates who are unable to follow the pace of industrial work. Such jobs are necessary and sought after. Yet the fact that over $80 \%$ have no training potential impinges on the rehabilitative mission of work. A three month rotation system, as advocated by the German Prison Law, would seem the right solution for all those who do not strictly need a "therapeutic" occupation. The English example of combining part-time domestic employment with education is also worth emulating. It is a pity that in the one sector that would offer excellent training opportunities, namely maintenance or "works", little is done to improve the skills of the workers. Simon's observation confirms our own that the officer-foremen (electricians, plumbers, painters, etc.) tend to do all the skilled work themselves and have neither the time nor the inclination to train their charges. ${ }^{68}$

\section{Prison Industries}

In most countries the Prison Service, through one of its agencies, takes on the role of entrepreneur and produces in its workshops goods needed for the internal market and, increasingly, for outside customers. This form of direct management is still prevalent in traditional English prisons where workshops run by the ESS (Enterprise and Supply Service) provide about 60 per cent of the jobs in production (close to 11,000 jobs). ${ }^{69}$ The percentage is somewhat lower in Germany, with an average of 40 per cent (38 per cent in Bavaria: 1,264 jobs; 37 per cent in Hesse:

\footnotetext{
66 Ministère de la Justice, Direction de l'administration pénitentiaire (2002), La modernisation du service général.

67 See below, part II, chap. 2, II 2 b.

68 Simon (1999), p.85-86.

${ }^{69}$ Industries Review Team (2003), p.12.
} 
341 jobs). In France, Prison Industries play only a minor role, supplying about 15 per cent of workshop places (1,236 jobs). ${ }^{70}$

To understand the reasons behind the low rates in France, we have to go back in history. Contrary to the practice in England and Germany, French prison labour in the $19^{\text {th }}$ century was not managed by the prison administration but handed over to an external contractor, responsible not only for work but for all other aspects of prison life, from accommodation to burial. For this service, the contractor was paid a set fee, supplemented by the income generated through prison labour. Even though the central prison administration slowly took control of most of the other functions, work remained solidly in the hands of the contractors until 1927. Only in some long-term prisons, where there was an acute shortage of work, the Prison Service managed to introduce the occasional workshop from the $1890 \mathrm{~s}$ on. Even after 1927, the organisation of work was still left mainly to external contractors, and the legal framework given to Prison Industries remained vague. It was not until 1950 that a proper budget was set aside to create workshops for the "industrial management of prison labour" (Régie Industrielle de l'Emploi Pénitentiaire, RIEP), but the RIEP remained an integral part of the Prison Service and had no organisational identity. ${ }^{71}$ If there was a profit, it could not be reinvested but was absorbed into the general budget. Only forty years later, in 1993, was the RIEP given some organisational and economic autonomy. This would have been the moment to expand its mission, but the new service (Service National pour le Travail en Milieu Pénitentiaire, SNTMP) did not live up to expectations and was replaced, five years later, by the SEP (Service de l'Emploi Pénitentiaire). Despite being more professional and business oriented, the SEP is still hampered by a budget that does not allow it to expand, and it is unlikely that the number of jobs will increase in any significant manner.

In Germany, the Prison Service, and hence Prison Industries (Eigenbetriebe), belong to the field of competence of the individual Bundesländer, and have been able to evolve more freely than in France. In most of the Länder, the central office only assumes the responsibility of marketing, coordination and support, and leaves the establishments free to organize their workshops as they see fit. Some Länder, for instance Baden-Württemberg and Lower Saxony, have opted for a more centralised structure, the so-called Landesbetriebe für vollzugliches Arbeitswesen (VAW), responsible for the coordinated management of all its workshops. The VAW forms an independent unit inside the Prison Service with its own budget and relative freedom of action. If there is a net profit, it is credited to the prison that has created it, not to the budget of the VAW or to the general treasury.

70 This is without counting the number of jobs in the semi- private prisons. If we add these 2600 jobs, the rate is even lower: 11.3 per cent.

${ }^{71}$ Loi no. 50-1615 of 31 décembre 1950. 
In the two Länder of our study, Bavaria and Hesse, we notice a trend toward greater centralisation, driven mainly by the need to make workshops more profitable. Both Länder stop short, however, of creating VAWs. The Bavarian central bureau for work attends to the commercial side: establishing the needs of the internal market, finding external customers, and selling the products. It also keeps a close eye on the prisons: if the workshops perform well, they are given a good deal of freedom; if they slacken in their efforts, it is not long before they are faced with an audit.

Until recently, Hesse was much less centralised than Bavaria. Decisions concerning the budget and the types of production were largely left to the governors and their staff. Each establishment bought their own raw materials on the local market, and only mayor investments had to be approved by the Ministry of Finance. This individualised approach was based on the philosophy that Prison Industries were not, in the first place, mandated to make money but to help inmates improve their employment skills. But in today's more strenuous economic context, the central bureau is obliged to rethink its strategy. If it wants to maintain or even increase the number of workshops, and thus the percentage of more highly skilled jobs, it has no choice but to centralize the planning of production. This could be done through a central bureau (Competenzcentrum) that would coordinate the production, be in charge of major investments and bulk acquisition of raw materials, and would also take care of the commercialisation of products on the external market.

As far as the English service is concerned, it went through a number of reforms since the 1970s, often accompanied by a change of name of the central bureau: DIS (Directorate of Industries and Supplies); DIF-Prindus (Directorate of Prison Industries and Farms); PSIF (Prison Service Industries and Farms); PES (Prison Enterprise Service) and, finally, ESS (Enterprise and Supply Service). The latest proposals by the Industries Review Team (as part of the Prison Service Head Quarters Review Programme) date from 2003. They try to render Prison Industries more efficient, closer to outside business, and with better communication lines to the establishments. ${ }^{72}$ Presently, the ESS controls the budget for primary materials and manages the central distribution depot. The staff of about 60 is in charge of planning, product coordination and logistics, but the organisation and management of workshops falls within to the competence of the governor, who can also conclude contracts with outside firms.

Despite their differences in size and organisation, the four Prison Industries have many elements in common. They face similar problems of attracting customers and balancing their books. They seek similar solutions, such as improving the quality of their products and the reliability of delivery dates, reorienting their production toward subcontracting, and increasing their visibility by using modern technology, 2.

72 Industries Review Team (2003). For a more detailed account see part IV, chap.2, I B 
e.g., via Internet. Their main product lines are still much the same: engineering, carpentry, textiles, printing, bookbinding, and desktop publishing, thus providing a mainstay of skilled and semi-skilled jobs rarely found in contract workshops. As a general rule, they offer better working conditions and adhere more closely to health and safety standards.

\section{Farms and gardens}

In England and Germany, farms and gardens form, together with Prison Industries and some domestic units, the commercial sector of work run by the Prison Service. Both countries are currently obliged to reduce the number of farms because of economic pressure, but are as yet reluctant to give them up altogether. France has already concentrated its farming sector in two specialized establishments, where it represents the main activity. Gardening has been downgraded in all three countries, again for economic reasons. In most prisons, it is no longer a commercial activity but a part of maintenance, i.e., of the domestic sector.

\section{B. Work provided by external contractors, associations or trusts}

Since Prison Industries are no longer able to provide the number of jobs needed for a growing prison population, administrations are forced to find other employers, in the first place outside firms but, especially in England, also an increasing number of non-profit organisations and trusts.

Contract work exists in two forms, the "true" and the "mixed". In both cases, the prison provides the manpower and the floor space, whereas the contractor is responsible for equipment, raw material and financial compensation, which must at least cover workers' salaries and the applicable employer's contributions. In the case of the true concession scheme, the contractor also provides the instructors and pays for the running expenses, such as light, water and heating. The prison is only responsible for the security staff. In the mixed scheme, it is the prison that provides the technical supervision and may even absorb the running expenses. It does not come therefore as a surprise that the French Prison Service, depending to 85 per cent on outside contracts, insists increasingly on the greater advantages of the "true" version, except in the case of very small contracts that do not warrant external personnel. ${ }^{73}$ In Germany, the "mixed" form still predominates. This has partly to do with the ambiguous formulation of its Prison Law ( $\$ 41$, al. 3 StVollzG), which seems to require the explicit consent of inmates for all work placements in contract shops. Even though this requirement has been invalidated by the Constitu-

73 Auvergnon/Guillemain (2006), p. 12. 
tional Court ${ }^{74}$ some eight years ago, German prisons still prefer providing their own instructors, in order to avoid any ambiguity as to who is in charge. In the three German research prisons, I encountered only one production unit that was staffed by instructors from the company, and this was because of its size ( 86 inmates) and the technicality of the tasks.

The question of external contracts is more delicate in England. Theoretically, the contracts are written and signed at ESS headquarters, but the system does not work well. In 2003, only one person was in charge of external contracts, despite the fact that these contracts represented 40 per cent of Prison Industries' activities. ${ }^{75} \mathrm{Gov}$ ernors, frustrated by the delays and missed opportunities, have reacted by signing contracts themselves and without necessarily informing the ESS. ${ }^{76}$ The type of contract used depends largely on the skill level required. For simple tasks, such as light assembly or packing, the prison will usually provide the instructors but, for bigger or more technical contracts, the firms tend to rely on their own foremen. There is no clear-cut rule.

The English Prison Service has also established a close collaboration with charitable foundations and trusts. These finance, for example, repair shops that refurbish sewing machines, typewriters or wheelchairs for third-world countries. Such workshops are very popular with inmates, not only because of good working conditions ${ }^{77}$ but also because of their social usefulness.

\section{Self-employment}

Both the French and the German Prison Laws make provisions for selfemployment (art. 718 nouveau CPP; art. D. 101, al. 3 CPP; § 39, al. 2 StVollzG). This kind of work is usually reserved for professional activities such as literary publications, graphic design or, rarely, the continued management of one's business. In France, where the use of personal computers is permitted and over 50 per cent of long-term inmates own a laptop, several have found a niche as independent computer operators. Without Internet access, this is still an uphill struggle. On the whole, self-employment remains the exception. This can be partly explained by the limited number of activities that lend themselves to the purpose. The fact that the modalities have not been spelt out clearly (working hours, repartition of earnings)

\footnotetext{
74 BverfGE 98, $169 \mathrm{~s}$. The Constitutional Court has stated that the consent of workers is only required in the case of external placements and only when authority over the worker passes clearly from the prison to the employer.

75 Industries Review Team (2003), p. 12.

76 Unfortunately, I was unable to get precise information on the number of these "wild" contracts or the conditions negotiated with the enterprises.

77 The pay scale tends to be higher than in Prison Industries' workshops, and work is often linked with education. For details, see below, part III, chap.1, III A 2.
} 
has not helped either. Last, but not least, "less eligibility" is also to blame for the exceedingly small number of inmates working as independents as most staff find it difficult to accept that "some inmates can get out of ordinary work and make more money in the bargain."

In Germany, the granting of self-employment was further hampered by a series of conditions imposed by application instruction for $\S 39$, al. 2 StVollzG. Permission could only be given if warranted by "exceptional circumstances", if the prisoner could provide all the material and equipment needed, if the activity did not cause any organisational inconvenience, and if it was demonstrably useful for resettlement. This restrictive interpretation was declared invalid by the Constitutional Court in 1998, ${ }^{78}$ but the number of self-employed inmates remains negligible. ${ }^{79}$

The English Prison Rules do not touch on the subject, and to the best of my knowledge there are no Prison Service instructions that either encourage or prohibit self-employment. It may well be possible that individual governors have authorized inmates to work on their own.

\section{The economic organisation of Prison Industries}

For the last thirty years, the ability of Prison Industries to generate income has steadily declined. A closer look at how workshops are managed in the three countries may help us better understand the reasons for these disappointing results.

\section{A. Workshop organisation and economic management}

\section{The organisation of productive units}

There are two aspects that strike an observer visiting prison workshops in the three countries. These are the difference in size, and the different concepts of efficient production.

The workshops I visited in France rarely employed more than 40 workers and often less. This is in part due to the smaller size of French long-term prisons - 190 to 300 inmates compared to 600 to 860 in England and Bavaria ${ }^{80}-$ but this is not the whole reason. Even the big Bavarian prisons have mostly small to middle-sized workshops, whereas in England 40 to 80 workers per production unit are the norm, and 120 people working in one hall is not exceptional. The difference in size has

\footnotetext{
78 BVerfGE 1998, $169 \mathrm{f}$.

79 In the three research prisons I did not come across a single case.

80 The prison of Schwalmstadt in Hesse is smaller, with a population of 301 inmates, and is closer to French norms.
} 
probably more to do with a different management philosophy. The ESS, as its predecessors, starts from the premise that the bigger the workshop and the more repetitive the tasks, ${ }^{81}$ the higher the productivity. This may not be the best approach in prison, not only because inmates would be more motivated and learn more if they were taught to manufacture the whole item, but also because the splitting down of tasks creates a greater level of operator inter-dependence. ${ }^{82}$ Given the high turnover rate and the frequent absences of inmates, output is slowed down rather than increased.

Prison Industries' workshops in France and Germany are still more craft-oriented and tend to train an all-round workforce. At the sound studio in Poissy, for instance, each operator has to be able to replace any of his colleagues before he is given a permanent position and, at Kaisheim, each inmate employed in shoe manufacturing is taught to produce the whole shoe. This does not mean, of course, that there is no division of labour, just that it is less pronounced than in England.

What is true for Prison Industries' workshops does not necessarily hold for contract work. Prisoners paid piece rates prefer repeating the same process over and over because it allows them to increase their pace and thus their income. This works out to the satisfaction of the contractor, who wants to get the job done as quickly as possible.

\section{The financial management}

a) The domestic sector

The budget for the domestic sector (wages, materials, social insurance contributions) is part of the overall budget of each prison, thereby giving the governor some leeway to increase it if necessary. For example, if the employment rate in the workshops sinks under a certain level, the number of jobs in the domestic sector can be increased, but only as a last resort. The new French guidelines explicitly recommend reducing the number of inmates employed in housekeeping in order to give them full-time and adequately paid jobs. It is hoped that this will improve both the quality of work and the satisfaction of workers.

In Bavaria and Hesse, Prison Service orders recommend employing 10 per cent of the total population in a domestic capacity, i.e., 20 to 24 per cent of the working population. The research prisons tended to stay relatively close to this recommendation (14.3, 14.5 and 10.6 per cent of the total population). It is surprising that Kaisheim, which has the lowest number of domestic jobs (10.6 per cent), is the prison with the highest unemployment rate (26.2 per cent).

81 Legge (1978, British Journal of Criminology, p. 10) uses the term "sectionalized flow" production, which means that the product is split down into its constituent manufacturing processes, each operator working on one process only.

82 Ibid., p. 11. 
English practice is characterized by pragmatism. "Rich" prisons that have managed to improve their budget through external contracts can increase domestic tasks. Those who depend entirely on Prison Industries for their productive sector do not have the margin to compensate for the lack of workshop places. As everywhere, category A prisons are in a class by their own, as their larger budget reflects the need to keep a more difficult population busy, if necessary with added cleaning jobs.

\section{b) External contracts}

On the continent, external contracts are usually signed by the governor and the head of the outside firm. In England, most contracts are still the responsibility of the ESS, but an increasing number are directly established by the governors. In all three countries, the fees charged will vary considerably depending on the wages negotiated, the level of the employers' contributions, the running expenses and whether there is a rental fee for the workshop space.

Despite the high number of outside contracts in France (85 per cent of all productive work), the terms negotiated do not make for a significant contribution to the overall prison budget. Overworked governors and their young assistants have neither the time nor the training to go in for hard bargaining, and are satisfied as long as the costs are covered.

In order to avoid all suspicion of unfair competition, contractors in Germany have to pay the same rates they would pay their own workers, with a discount of 25 to 30 per cent for lower productivity rates. They also have to pay social security contributions, ${ }^{83}$ a fee for the use of the premises and, sometimes, the cost of the instructors provided by the prison. Given that inmates only receive a fraction of the negotiated wages, contract work should be a money making proposition. But even here there exists a big span between "good" and "bad" contracts, and prisons that are hard pressed for jobs accept conditions that just allow them to break even.

In England, the financial agreement reached depends much on the nature of the contract. In the case of "mixed" concession, the prison has to provide (and pay for) the instructors and this virtually wipes out any gains, despite the low salary paid to inmates. The situation is different in the case of Private Finance Industries (PFI), i.e., workshops run and financed by big companies. My own experience being limited to one prison that worked with four of these big companies, I cannot state apodictically that all contracts of this nature are as advantageous as those of HMP Swaleside. There the net profit amounted in 2002 to $€ 760,000$, an amount superior to the total income created by all other prisons in Kent and Sussex, despite the fact

83 These contributions are, however, much reduced and do not include contributions to the pension fund nor to unemployment insurance. 
that PFI workers receive enhanced wages three to four times higher than those paid by Prison Industries.

\section{c) Prison Industries}

The business side of Prison Industries is fraught with more obstacles than that of contract work, as all head offices (ESS, RIEP or the German offices) are responsible for business management without being given the legal status that would allow them to do their job well.

In France, the RIEP still is officially a simple commercial account without the status of an independent legal entity. Its 2002 budget was based on an expected income of $€ 23,115,000$, expenses of $€ 22,939,500$, and a profit of $€ 175,500$. This result, if not quite brilliant, would have been respectable, had it not been for the fact that two-thirds of the salaries of the prison staff working for the RIEP did not figure in the budget. In other words, the RIEP benefited from hidden subsidies to the amount of $€ 4,000,000.84$ Even if its rehabilitative mission does not put the RIEP under the same economic pressure as ordinary business enterprises, it has to balance its books. The law allows a maximum overdraft of $€ 609,800$, which would be largely exceeded if the RIEP had to factor in the full cost of its personnel.

The situation is quite different in Germany, at least in Länder like Hesse and Bavaria that have not opted for a fully centralized organisation of Prison Industries. Each establishment has its individual workshop budget, which includes funds for buying raw materials. The head office compiles the balance sheets but, in its report to the Finance Ministry, does not distinguish between the income engendered by the so-called Eigenbetriebe (Prison Industries) and the contract workshops. It is therefore difficult to evaluate the profit made by each. Bavaria, in 2001, showed a net profit of $€ 12,600,000$ with JVA Straubing alone contributing $€ 2,000,000$. As in France, these figures are slightly inflated since they do not include expenditures for part of the instructors' salaries paid out of the general prison budget. The figures in Hesse are less favourable despite the efforts of a dynamic and innovative team at the Ministry of Justice, and the balance sheet has been negative for several years in a row. 85

In England, the unhappy division of competences between the ESS and the prison governors has hampered the efficient management of Prison Industries. As it now stands, the governors and their industrial managers are responsible for the wages of inmates and instructors, and they decide on the equipment, but the ESS

84 Rapport Loridant, p.71. A finance bill passed in 2001 (loi organique du 19 juin 2001 relative aux lois des finances) will eventually put a stop to this practice and make a change to the status of RIEP unavoidable for survival.

85 Income 2001: $€ 10,778,604$; expenditure workshops: $€ 4,567,660$; expenditure wages/social insurance: $€ 9,870,271$; total expenditure: $€ 14,437,931$; deficit: $€ 3,659,327$. Source: Justizministerium Wiesbaden, 2002. 
controls the number of jobs and handles the budget for raw materials. This arrangement does not always work out to the satisfaction of all parties involved, as seen in the following example: In December 2001, the big textile sector at HMP Featherstone (120 positions) almost had to close down until January because the budget for raw material assigned by the ESS had been used up. The ESS refused a request for a bridging credit, in spite of the damage caused not only to the workshop and its customers, but to several other prisons whose production depended on the pre-cut pieces provided by Featherstone. In January, a request to temporarily increase the number of workers to clear up the backlog was also turned down.

In England as in Germany, it is difficult to obtain precise figures on the economic performance of Prison Industries, as the official statistics give the income but not the expenditures of the workshops. The following forecast was provided by the Industries Review Team (2003, Annex E).

Table 6: English Prison Industries: budget forecast for 2003/2004

\begin{tabular}{|l|c|}
\hline Sales & \\
\hline Internal & $£ 40,170,367$ \\
\hline External & $£ 7,511,225$ \\
\hline Total & $£ 47,681,592$ \\
\hline Expenditures & $£ 30,678,037$ \\
\hline Cost of internal transfers & $£ 25,812,040$ \\
\hline $\begin{array}{l}\text { Administrative costs (in- } \\
\text { structors, administration } \\
\text { and support) }\end{array}$ & \\
\hline Total & $£ 56,490,077$ \\
\hline
\end{tabular}

This sizable deficit is surprising since the wages paid to inmates are very low and the Prison Service does not have to defray the social security contributions.

d) The overall economic performance of prison labour

Should additional proof of the economic decline of prison labour be required, a look at some Germany prisons (the only ones to provide precise statistics on productive work as a whole) will suffice: 
Table 7: Contribution of prison labour to the cost of imprisonment in Germany: 1989-1998

\begin{tabular}{|l|l|l|l|}
\hline $\begin{array}{l}\text { Former Federal Re- } \\
\text { public }\end{array}$ & $\begin{array}{l}1989-91 \\
\text { Mean value }\end{array}$ & $\begin{array}{l}\text { Change in per } \\
\text { cent }\end{array}$ \\
\hline $\begin{array}{l}\text { Total expenditure of } \\
\text { the Prison Service }\end{array}$ & DM 2,195,900,000 & DM 3,007,800,000 & +40 per cent \\
$(€ 1,097,950,000)$ & $(€ 1,503,900,000)$ & \\
\hline $\begin{array}{l}\text { Income from prison } \\
\text { labour }\end{array}$ & DM 281,167,000 & DM 283,452,000 & +0.8 per cent \\
\hline $\begin{array}{l}\text { Expenditure due to } \\
\text { prison labour }\end{array}$ & DM 202,984,000 & DM 251,972,000 & +24.1 per cent \\
\hline $\begin{array}{l}\text { Net profit from prison } \\
\text { labour }\end{array}$ & DM 78,183,000 & DM 31,480,000 & -59.7 per cent \\
\hline $\begin{array}{l}\text { Percentage in relation } \\
\text { to the whole expendi- } \\
\text { ture of the Prison } \\
\text { Service }\end{array}$ & 3.56 per cent & 1.05 per cent & \\
\hline
\end{tabular}

Source: A. Neu (2001), Den verfassungsrechtlichen Vorgaben knapp entsprochen. NK, 2, p. 23.

These figures speak for themselves: in the ten years from 1989 to 1998 the net profit created by prison labour has shrunk by 59.7 per cent. But the decline began earlier. In 1970, the gain generated by the workshops covered 26.3 per cent of the total cost of imprisonment in the former Federal Republic. By 1984, this percentage had been reduced to 13.5 per cent. ${ }^{86}$ The downtrend continues, as the 80 per cent wage increase for workers in 2001 and higher unemployment contributions have further eroded the profit margin.

We have used the example of Germany but there is no indication that the two other countries have fared better. Let us examine two factors that are relevant for this decline: 1) the importance attached to the economic performance of workshops and 2) organisational inefficiencies. Other factors will be dealt with in part IV. ${ }^{87}$

\footnotetext{
86 Dünkel/van Zyl Smit (1998), Arbeit im Strafvollzug, in: Festschrift Kaiser, p. 1172.

${ }^{87}$ Part IV, chap. 1.
} 


\section{B. Two key factors responsible for the lack of economic success}

\section{Shortcomings in business orientation}

It seems reasonable to assume that the stronger the business orientation, the better the economic performance. Of the three countries studied, France is the one that attaches the least importance to the economic performance of its workshops. Prison Industries only need to break even, and as long as the limit on overdrafts is respected, no sanction is attached to poor performance, and no reward is made for good management. Not surprising, the RIEP has a difficult time shedding its image as an inefficient organisation. Most governors do not show particular commercial acumen and are happy as long as the external contracts cover the cost.

The English attitude is quite different. All workshops are expected to make money, even if these expectations are not always fulfilled. In establishments where Prison Industries provide the bulk of employment, the Head of Industries does not work alone as in France. He or she is given a team of two or three collaborators to assist him in the task of finding new customers, planning production and taking care of accounts. As far as outside contracts are concerned, governors have every interest to negotiate the best possible deal since part of the profit is credited to the establishment, which is not the case for gains made by ESS workshops.

In Germany, the importance given to the economic aspect of work varies from Land to Land. Bavaria has a very strong business orientation, whereas Hesse gives priority to rehabilitation. But even in Hesse, economic considerations are stronger than in France. Each of the prisons I visited had two heads of work: a financial administrator (Leiter der Arbeitsverwaltung) and a workshop manager (Werkdienstleiter). The first works full-time to negotiate contracts, manage finances and find new customers - activities that are dealt with in France by an assistant governor on a very part-time basis. The second runs the workshops and the productive units of the domestic sector, allocates the workers, controls the raw material, and engages actively in the search of clients or contractors. In a big prison like Straubing, each of the two heads has a staff of three or four. Each contract that brings in money and creates jobs is welcome, be it big or small, private or public, for subcontracting or as a concession. Very small orders are even accepted without going through the formality of a signed convention. Although workshops do not benefit directly from gains made, both staff and workers are more motivated because they know that their work is taken seriously and is valued in the eyes of both the director and the ministry.

The link between business orientation and economic success is nevertheless not as strong as it might appear at first glance. The Bavarian workshops perform better than the others, but the English Prison Service, with similar business aspirations, does not do as well. The losses incurred by the ESS are even proportionally greater 
than those sustained by the French régie, which is ranked lowest for its commercial drive.

\section{Organisational weaknesses}

The French Loridant Report puts much of the blame for the poor economic results of prison labour on organisational problems, both legal and structural.

1) The legal organisation of Prison Industries (RIEP, ESS, Eigenbetriebe) hampers economic performance and the creation of a sufficient volume of work. The number of jobs is stagnating everywhere, particularly in France, but also in Hesse and in England. ${ }^{88}$ The structures of both RIEP and ESS are too inflexible to adapt to changing production requirements. Up until twenty years ago production created demand, today it is demand that spurs production. The new level of reactivity called for poses an almost insurmountable obstacle for prison workshops. The smaller and less centralized work organisation in the German Länder is, in this respect, more advantageous. The French RIEP is further handicapped by legal restrictions that prevent it from bidding in calls for tenders if it cannot respond to the whole contract but only to part of it. If there is, for instance, a call for cell furniture, and the RIEP can only fabricate beds and tables but not sanitary equipment, its tender will not be considered, whereas an outside firm in the same situation is allowed to subcontract the elements it cannot produce itself. 89

2) Production standards, especially for products for the internal market, have never been consistently high, and prisons tend to turn to outside suppliers that give them a better quality-price ratio. This is good for their budget but has a negative effect on the business volume of their workshops. Both ESS and RIEP claim that the quality of their products has greatly improved and compares favourably with those of outside competitors. Yet the Industries Review Team still sees the need to include in its reform package a clause that would compel prisons to purchase the goods produced by its workshops and to bar outside competitors. ${ }^{90}$

3) No business can operate without taking risks, but in prison bureaucracy and an inflexible budget make experimentation difficult, if not impossible. A Head of industry in England explained the problem in the following terms: "We don't dare any longer lance a new product because the ministry does

88 Rapport Loridant, (2002), p. 53; Justizministerium Hessen, 2002, Arbeitsgruppe "Erhöhung der Beschäftigungsquote"; information obtained during two interviews at the ESS head office.

${ }^{89}$ Rapport Loridant (2002), p. 69-70.

90 Industries Review Team, (2003), p. 62. 
not give us the necessary time to develop it. If we do not make a profit during the first year, next year's budget will suffer."

4) Prison Industries are part of the Prison Service and are bound by the same government rules on hiring and firing. This means that, unlike outside firms, they cannot choose their staff freely and replace people who are not suitable. To alleviate this problem, England has introduced a strict selection process and relies to a large extent on outside personnel and instructors. Germany, which also operates a rigorous selection process, imposes, in addition, a lengthy training period for its head instructors. ${ }^{91}$ The RIEP has to make do with the available personnel. When the headquarters were moved in the late 1990s from a Parisian suburb to Tulle, a small town in central rural France, support to staff in the various prisons was further weakened.

5) As far as contract work is concerned, prison administrations have been quite oblivious to the radical changes that have taken place outside, in particular the rapid transfer of production to countries with lower labour costs. Instead of training inmates for more specialized work with higher added value, administrations still aim for low-skilled jobs in light assembly or packaging that can be done faster and at a lower cost in Rumania or Vietnam.

6) Unsatisfactory external contracts that barely cover the cost are indicative of the weak negotiating position prison administrations find themselves in. They need contract work to create jobs for the growing number of inmates, but outside firms do not need prisons. They can shift their labour intensive production units outside the country or, if this is not practicable, turn to local protected workshops that offer better tax breaks, a more stable workforce and none of the security hassles they have to put up with in the prisons.

To sum up: current weaknesses in legal and material organisation make it difficult for prison labour to achieve its rehabilitative and economic goals. Prison Industries are hampered by rigid structures and an emphasis on production for the internal market. The domestic sector cumulates the double handicap of unskilled jobs and low wages. Outside firms, with a few rare exceptions, try to get the best value out of their prison investment and feel under no obligation to provide training. Given the actual shortage of jobs, administrators are no longer in a position to impose conditions that correspond to the goal of rehabilitation.

We must now see, in the next chapter, whether the legal status of inmate workers is such as to allow them to leave prison better prepared than when they came in.

91 A fully qualified master craftsman has to spend one full year at the staff college before taking up his functions. 


\section{Chapter 2: The legal status of working inmates}

Serving a prison term necessarily implies the loss of certain rights. The question is: what rights? This can be answered in the light of one of two assumptions. The first takes for granted that inmates, once condemned, lose all prior rights except those that are explicitly granted. The second takes the opposite view, and removes only those rights that are strictly incompatible with the prison regime. In the case of prison labour, the first assumption prevails in all three countries, i.e., only those employment rights that have been clearly stated either by law or by regulation come into play. This chapter examines the reasons and the consequences of this choice and looks at the limited rights, protections and benefits that have nevertheless been extended to inmate workers.

\section{Refusing Employee Status}

All European prison regulations have in common that inmates at work are denied employee status because they cannot sign a contract of employment. The French Code of Criminal Procedure is formal on this point: "Work relationships of inmates do not constitute a contract of employment" (CPP, art. 717-3, al. 3). ${ }^{92}$ The two other prison laws, though less explicit, are based on the same principle. Until 1972, the German Prison Service had unchallenged authority over its inmates (spezielles Gewaltenverhältnis), and this rendered contractual relationships between the two parties impossible. Even now, the fact that prison labour remains compulsory precludes the possibility of a contract. In England, case law (Pullen v. The Prison Commissioners, 1957) excludes prisoners from the rights and protections granted to workers by the Factories Act of 1937. This precedent has been reinforced by a second ruling, Davis v. The Prison Commissioners (1963), which states that the work performed by inmates does not constitute a master-servant relationship, in other words, that the necessary relationship of subordination that characterizes an employment contract does not exist. ${ }^{93}$ These decisions may seem arbitrary and out of date, yet they cannot be dismissed off-hand for there are several good arguments in favour of restricting the application of employment law, although there are equally strong arguments for granting inmate workers, if not employee status, at least all employment rights and protections that are not strictly incompatible with the prison regime. We shall examine both sides of the question.

\footnotetext{
92 "Les relations de travail des personnes incarcérées ne font pas l'objet d'un contrat de travail."

93 Vagg/Smartt (1999), in: van Zyl Smit/Dünkel (eds.), p.51.
} 


\section{A. Arguments for and against excluding inmates from employee status}

\section{Arguments in favour of exclusion}

a) Arguments based on tradition

In the initial phase of forced labour - in the time of galleys and transportation punishment consisted essentially in the exploitation of the physical force of the convicts. It was, in a manner of speaking, a utilitarian version of corporal punishment. In this context, talking about a work contract would have seemed absurd. With the rise of imprisonment in the late $18^{\text {th }}$ century, the core of punishment shifted to the loss of liberty, but work remained an essential part of the sentence and retained its afflictive component. Given that workers' rights were only minimally protected at the time, their extension to inmates was not under discussion. ${ }^{94}$ The link between work and punishment has now been weakened and, in conformity with the Minimal Rules for the Treatment of Offenders, work has become part of treatment and rehabilitation. ${ }^{95}$ France has forged ahead and removed the compulsory aspect of labour, thus theoretically opening the way for a contractual relationship. ${ }^{96}$ Nonetheless, the traditional notion that prison labour is governed by prison rule and intrinsically different form outside work has not been dislodged.

A second factor responsible for the reluctance to grant inmate workers employee status has to do with the relatively late introduction of employment legislation. Codification in France dates from 1910, but social protections were only progressively introduced after 1945. The situation is no different in Germany or England. We have quoted the Factories Act of 1937, but the majority of employment laws are much more recent: for instance the Employment Rights Act or the National Minimal Wage Act were only passed in 1998. Since prisons are notoriously slow in following developments on the outside, it is hardly surprising that they should be slow in adopting changes made in employment rights.

b) Arguments based on economic and security considerations

The disparity between an inmate's obligations and his rights at work are often justified by the risk of losing external contractors, the impossibility of assuming additional costs for extended social protections, but also by the risk to security if inmates were granted collective rights. These arguments cannot be easily dis-

94 At the 5th International Prison Congress in Paris the question arose as to whether or not working inmates should be given a stipend. The answer was negative: as inmates are already provided with accommodation and food, there is no need to pay them for their work.

95 Council of Europe, 1973.

96 Loi du 22 juin 1987 relative au service public pénitentiaire. Only two other European countries have taken the same step: Spain in 1979 and Denmark in 2001. However both have maintained the obligation of an alternative activity. 
missed. External firms choose prisons primarily because they allow them to get around some aspects of employment law. They pay reduced employers contributions and are exempt from several additional payments, such as statutory holidays, mandatory time off, redundancy payments, $13^{\text {th }}$ month, and so on. Furthermore, there are no statutory notice periods, no trial periods, and no sanctions when contracts are abruptly terminated, no guaranteed income, no union representation, no binding collective agreements, no worker participation, and no right to strike. ${ }^{97}$ If workers were included in a comprehensive social security package like outside workers, the cost involved would be considerable. In France, for instance, employer contributions in prison are $16 \%$ compared to $46 \%$ outside. In Germany, where Prison Industries play a more important role, each extension of social benefits and each pay increase would put a considerable strain on an already tight budget. The same holds true for England, which has so far resisted all benefit payments.

Order and security are also valid arguments against the wholesale introduction of employment rights. Prison Services fear that such a radical step would disrupt the hierarchical staff-inmate relationship and render the prison ungovernable. This fear may be exaggerated, but it is obvious that some rights, such as the right to strike, cannot be granted. It is less obvious that restrictions should extend to rights that do not impinge on the control function of the prison, such as workers' representation.

\section{c) Legal arguments}

A contract of employment is characterized by three elements: a relationship of subordination (the employer giving direction, the employee following them), wages paid in exchange for work, and the free consent of the parties that enter into such an agreement. The first two elements are present in a prison setting, but the last element poses a problem. Both in England and Germany the compulsory nature of work precludes the presumption of free will on the part of the inmates. Even in France, some authors argue that the position of prisoners is too vulnerable to guarantee the degree of independence required by the ILO convention. ${ }^{98}$ If, for instance, the granting of parole or of good time depends on the inmate accepting any kind of job, free consent can no longer be presumed.

There are other legal difficulties as well: regular forms of employment contracts (permanent, temporary, etc.) do not fit the prison context. An adaptation seems possible when the Prison Service acts as "employer", but becomes problematic as soon as a third party is involved, as in the case of contract work or work provided by a trust or an association.

\footnotetext{
${ }^{97}$ Lorvellec (1994), in: Supiot (ed.), p. 256.

98 Danti-Juan (1997), Revue pénitentiaire et de droit pénal, p. 127-135.
} 
Despite theses difficulties, a growing number of commissions and organisations are lobbying for the introduction of an adapted contract of employment and an extension of workers' rights and benefits. ${ }^{99}$ Let us examine the reasons that are put forward.

\section{Arguments against exclusion}

a) Employee status promotes rehabilitation

As we have seen in part one, many inmates do not have stable jobs before they are put in prison and their prospects on release are even worse. ${ }^{100}$ Extending employment rights and benefits to inmate workers would not magically change this situation, but it would be a step in the right direction. If inmate workers were treated like ordinary employees, workshops would become the one place in prison where prisoners could rely on being treated fairly or on finding redress for legitimate grievances. It would thus alleviate their feeling of being powerless and at the mercy of an arbitrary authority, often said by inmates to kill all desire to change. Being an employee does not only confer rights, it also imposes duties. Prison has been criticised for treating inmates like children that are unable to handle responsibilities and cannot be expected to live up to outside standards, with the result that many lose the stamina to assert themselves in a competitive labour market. Signing a contract with binding obligations would make them face up to the consequences should their performance not be up to par.

\section{b) Economic benefits}

Both opponents and advocates of employment rights use economic arguments to carry their point. The first group stresses the additional expenses, the second the increased benefits. The (few) experiments made in the three countries with employment contracts all show an increase in productivity in the workshops. ${ }^{101} \mathrm{By}$ introducing a statutory trial period, workshop managers can select motivated and capable candidates. The higher cost involved (employer contributions, statutory holidays, indemnities, etc.) also forces governors to place workshop efficiency higher on their priority list by opting, for instance, for a continuous workday and reducing exaggerated security measures.

99 For example, FARAPEJ, GENEPI and the Observatoire International des Prisons. The (aborted) French Bill for a comprehensive prison law (2001) contained a proposition for a modified employment contract; the new Belgian prison law has adopted such a contract.

100 Part I, chap. 1, A, 1.

101 In France the sound studios at the two category A prisons, St. Maur and Poissy; in Germany the "Hamburger Modell", and in England the in-house workshops of HMP Latchmere House have opted for "real" work contracts. 


\section{c) Reasons of equity}

Considerations of equity represent a strong counterargument to the legal difficulties invoked in favour of preserving the status quo. The denial of employee status deprives inmates of a whole set of rights and benefits that they enjoyed outside and that are not incompatible with the safe management of prisons. This constitutes an unnecessary, and hence unjustified, aggravation of their sentence.

\section{B. The consequences of the refusal of employee status}

\section{Curtailment of rights and benefits}

Without a contract of employment, inmate workers are deprived of a substantial number of individual and collective rights. There is no agreement on hiring conditions, no trial period, no protections against unfair dismissal or redundancy, no compensatory payments for days lost because of a work accident or work related illness. Statutory holidays are out of the question, except for Germany, where they have been included among the privileges granted. Inmates also have no guarantee as to the stability of their work: they may be switched from one job to another, their hours can be shortened or their job disappears from one day to the next. There is nothing the inmates can do about it, and no redundancy payments can be claimed. ${ }^{102}$ All rights that would give them a certain control over their work: the right to express their opinion, to have a workshop representative, join a union or even to strike, are as inconceivable in France as they are in England or Germany. ${ }^{103}$

Even if one can understand the concerns of the prison administration if inmates were given full union rights, a radical curtailment of all manifestations of collective participation is unwarranted. The French Economic and Social Council and the Parliamentary Commission of 2000 both recommend that inmates be allowed to participate in the running of workshops as long as this does not create a sizable risk to maintaining control. ${ }^{104}$ The Talandier Report proposes for instance a box for complaints and suggestions in each workshop, the right to elect a workshop representative, and participation in regular meetings with contractors and heads of work. These modest proposals have already been put to the test in Canada. Art. 73 and 74 of the Corrections and Conditional Release Act (1992, c. 20) explicitly recognises

102 In France, the contract between the Prison Service and an outside firm can, in theory, contain a clause obliging the contractor to pay inmates compensation if the contract is terminated prematurely but in my experience this has never happened. In England and Germany the Prison Service continues to pay the wages, as long as the work stoppage is of a limited duration.

103 Lorvellec (1998), in: Supiot (ed.), p. 258 ; Auvergnon/Guillemain (2006) p. 157.

104 Rapport Talandier (1987) p.16; Rapport de l'Assemblée nationale (2000) p.144 ; 169 f. 
the right to collective expression and, as far as I know, without negative repercussions.

\section{Restrictions of procedural rights}

Subjective rights are characterized by the fact that they can be enforced, if necessary, by a court decision. Given the very small number of rights granted to inmate workers, private law remedies are limited. Without employee status, access to employment tribunals is ruled out. At best inmates can hope for judicial review of an administrative act or decision that has been damaging to their interests.

In England, prison authorities owe a duty of care to inmates in their charge and compensation payments, in case a neglect of this duty should result in injury. ${ }^{105}$ In such cases, inmates can appeal to a civil court to obtain redress. However, in the case of a work accident inside prison there is no presumption of a breach of duty of care. Unlike workers with employee status, inmate workers have to prove negligence on the part of the prison authorities. Given the unequal standing of the two parties and the difficulties inmates face to get hold of such evidence, lawsuits of this kind are hardly ever attempted. It is true that the Home Office tries to remedy this situation by paying injured inmates an ex gratia indemnity, but this decision is discretionary, and does not compensate for the lack of procedural guarantees. Inmates must thus rely on administrative courts, claiming that their interests have been damaged by an ultra vires decision on the part of the prison administration. This is the case if the decision is contrary to an expressed provision of the law (illegality), if it involves the unreasonable exercise of discretion (irrationality), or if it is taken in breach of certain procedural safeguards, such as natural justice or the duty to act fairly (procedural impropriety). ${ }^{106}$ Again, the chances of success are minimal. Inmates may argue that a hiring or firing decision was unfair or unreasonable, but except in the case of flagrant racial discrimination no administrative court will overrule an internal decision of that nature. ${ }^{107}$ Judicial review is further hampered because the principle of retention of previous rights has been restricted by jurisprudence. In Raymond v. Honey, 1983, Lord Wilberford allowed for their derogation "by necessary implication." Richardson notes that judges are reluctant to interfere in what they consider internal administrative decisions and tend to favour the authorities through a generous interpretation of "necessary implication". ${ }^{108}$

105 Ellis v. The Home Office (1953) and Christofi v. The Home Office, quoted in Richardson (1994), in: Player and Jenkins (eds.), p. 81.

106 Ibid., p. 83-84.

107 In Alexander v. The Home Office (1988), Alexander, who was of Caribbean origin, successfully sued for damages for being refused a job in the kitchen on the basis of two assessment reports containing racial slurs. Quoted in: Livingstone/Owen/Macdonald (2005), p.193.

108 Richardson (1994), in: Player/Jenkins (eds.) p. 90. 
English inmates are better advised to seek redress for their grievances through extrajudicial channels, such as the Independent Monitoring Board or the Prison Ombudsman, even if these two instances only have advisory power.

The rights of German inmates at work are, at least in principle, better protected. Even if they cannot bring their grievance before an employment tribunal, the Prison Law ( $\$ 109-121$ StVollzG) provides a whole series of judiciary controls, in particular judicial review by a division of the regional courts created to deal with the execution of prison terms (Strafvollstreckungskammer, $\S 109$ ). It is a particularity of this court that, although part of the criminal division, it deals with administrative matters without being bound either by the rules of an administrative tribunal or by the jurisprudence of this field. ${ }^{109}$ Despite these guarantees, the position of the workers remains weak because, in the absence of true subjective rights, the courts can only determine whether the administration had the right to act or whether the decision was taken within the bounds of reasonable discretion. A study by Hartmut-Michael Weber shows that only \% of the decisions are in favour of the inmate. ${ }^{110} 111$ Contrary to English or French inmates, German prisoners can however appeal to the Federal Constitutional Court (Bundesverfassungsgericht) if they consider that one of their fundamental constitutional rights has been violated. The most important recent decisions concerning prison labour, such as the minimal level of remuneration and protections against unfair dismissal, have all been rendered by the Constitutional Court. 112

The position of French inmates was, until recently, so weak that one of the leading French criminal lawyers, Pradel, could sum it up as follows: "In France, the situation as far as judicial review is concerned, is very simple: the inmate has access neither to the administrative nor to any other tribunal." 113 On the rare occasion when an inmate tried to bring an action before an employment tribunal, the tribunal declared itself incompetent, as the inmate lacked employee status. This decision was upheld by both the Court of Appeal and the High Court (Cour de cassation). ${ }^{114}$ In this particular instance, the inmate had worked for three weeks for an external contractor before being dismissed when the contractor withdrew before term. For the three weeks worked, the inmate was only paid $€ 30$, whereas the average weekly

$109 \mathrm{Lu}(1998)$, p.45.

110 Weber (1992), in: Cremer-Schäfer (ed.), p. 40.

111 Dünkel (2002, in: Céré, ed., p. 233) is slightly more optimistic. But even in the studies quoted by him, the success rate never exceeds $5 \%$ in the lower court and $8 \%$ in the court of appeal. He also quotes the possibility of an administrative review (§ 164 StVollzG), which is however rarely used (ibid. p. 220).

112 BverfGE 98, 169; NStZ 1994, p. 104.

113 Pradel (1993) in Pradel (ed.), p. 240.

114 Giudicelli-Delage and Massé (1997), Droit social, n 4, p. 344. 
pay in French workshops is around $€ 115$. Outside, the employer would have had to adjust the salary and pay an indemnity for breach of contract, but not in prison. This occurred in 1996. Since then, two new laws voted in 2000 give inmates slightly better chances to seek redress against unfair decisions. ${ }^{115}$

The first law, pertaining to the Rights of Citizens when Dealing with Public Administration (12 April 2000), considers the Prison Service as an administrative service among others. Thus, it takes away its previous special status and imposes the same obligation toward inmates as other services have toward their users. The Prison Service has, in particular, to provide grounds forits decisions and to open up the possibility of judicial review for all actions and decisions that negatively affect the prisoner. In addition, inmates have the right to counsel during administrative hearings in cases that do not concern purely internal matters. ${ }^{116}$

The second law, pertaining to the Protection of the Presumption of Innocence and the Rights of Victims (15 June 2000), introduces new procedural safeguards for decisions affecting sentence adjustments. The cumulative effect of the two laws has greatly reduced the area of administrative decisions that were considered purely "internal", i.e., decisions concerning the everyday running of the prison that have no impact on the legal situation of the inmate and are discretionary. All aspects of prison labour traditionally fell into this category: removed from the sphere of employment law, they were deemed an internal matter, with the administration deciding as it saw fit on matters not considered important enough to affect the legal position of inmates. This interpretation has become untenable. First, because decisions concerning hiring and firing undoubtedly do have an effect on the legal position of inmates, as performance at work is one of the criteria used to measure the progress made toward rehabilitation (Art. 717-3, al. 1 CPP). Second, because the discretionary nature of the decision has been reduced through the creation of multidisciplinary allocation boards. These boards are bound by narrowly defined criteria and have to motivate their decisions. Yet French courts remain as cautious as English or German tribunals. Since the introduction of the new legislation, very few decisions have been rendered concerning work: none on hiring, and only one on unfair dismissal for a disciplinary incident. Another application, this time in the case of dismissal for incompetence, was rejected, as the administrative court considered dismissal for incompetence to be a purely administrative matter over which the court had no jurisdiction. It is true that there is an objective difference between the two cases. In the case of dismissal on disciplinary grounds, the criteria are clearly circumscribed and the conflict is limited to two parties: the administration and the inmate. In the second case, the decision is often taken under pressure from an external contractor who wants to get rid of a slow or incompetent worker. Here, the

115 For more information see: Péchillon et Herzog-Evans (2003), p. 6.

116 Herzog-Evans(2002), in: de Schutter/Kaminski (eds.), p. 26-27. 
distinction between tolerable levels of incompetence and those that actually harm the production are less clear-cut and the evidential proof of an arbitrary decision more difficult to provide.

As far as hiring is concerned, even if a refusal does affect the legal position of the inmate and is thus not merely an internal administrative matter, it is difficult to prove that the hiring committee acted arbitrarily or in a discriminatory way. Given that the demand for jobs almost always exceeds the available openings, any committee can come up with a plausible reason why it chose one candidate over another.

The protection of inmate workers by the courts remains thus weak in all three countries. The inmates who have answered the questionnaire agree with this assessment. When asked about their options when encountering problems at work, they gave the following answers:

Table 8: Inmates' preferred option in case of a disagreement at work

\begin{tabular}{|l|c|c|c|l|l|}
\hline & $\begin{array}{l}\text { Speak to } \\
\text { the work- } \\
\text { shop su- } \\
\text { pervisors }\end{array}$ & $\begin{array}{l}\text { Seek an } \\
\text { interview } \\
\text { with the } \\
\text { governor }\end{array}$ & $\begin{array}{l}\text { Contact a } \\
\text { non-judicial } \\
\text { control or- } \\
\text { ganisation }\end{array}$ & $\begin{array}{l}\text { Try to get a } \\
\text { judicial } \\
\text { review }\end{array}$ & $\begin{array}{l}\text { Remain } \\
\text { silent }\end{array}$ \\
\hline France & $82.4 \%$ & $44.4 \%$ & $17.9 \%$ & $\mathbf{8 . 8 \%}$ & $55.4 \%$ \\
\hline Germany & $84.9 \%$ & $25.2 \%$ & $17.2 \%$ & $\mathbf{2 8 . 8 \%}$ & $50.4 \%$ \\
\hline England & $83.5 \%$ & $37 \%$ & $31 \%$ & $\mathbf{1 3 . 3 \%}$ & $63.4 \%$ \\
\hline
\end{tabular}

Inmates have a positive image of their workshop supervisors: over $80 \%$ would turn to them first. Governors are perceived as more accessible in France and England than in Germany. However, the hope put in judicial review is higher in Germany than in the other two countries. In all three countries, more than half prefer to shut up.

\section{Partial Extension of Rights and Benefits}

In order to alleviate the disadvantages inmate workers face by being excluded from a contract of employment, legislation has extended to them some provisions of employment law, especially in the three areas of pay, general working conditions, and social benefits.

\section{A. Subjective rights}

The number of enforceable rights is extremely limited. In Germany, a case could be made for the right to work. Elsewhere, the only other right that has been generally recognized is the right to be paid. 


\section{The right to work?}

The Prison Services in the three countries are required to provide work for the inmates in their care, ${ }^{117}$ but this obligation does not necessarily imply a corresponding right to be given a job. A right to work has been rejected by the courts and by doctrine in England and France. In Germany, the situation is less clear-cut: while prison administrations deny it, some legal experts claim that it exists. I shall examine this more closely after summarizing the French and the English position.

The preamble of the French Constitution recognizes the right to work for every citizen, but this right was never considered to be more than a programmatic declaration, implying at the most an obligation to provide assistance for the unemployed who cannot make ends meet. In the case of prisoners, the formulation of the law (art. 99, al. 1 Code de procedure pénale) might give the impression that they have a stronger claim than ordinary citizens: "Inmates, whatever their category, can ask to be given a job." Unfortunately, the list of derogations (work is provided according to the prison regime [...], the needs of the establishment and the local job opportunities $)^{118}$ releases the administration from any obligation to show results.

Neither the English Prison Law not the Prison Rules make it an obligation for the Prison Service to provide work for all inmates applying for a job. Several Prison Service Orders and Reports like the Woolf Report do advocate full employment, but always within the limits of local possibilities. Unlike France, the Prison Service recognizes a certain obligation toward inmates who are on the waiting list for a job placement by paying them an "unemployment indemnity" of roughly $€ 5$ per week.

The German situation differs from the other countries in the way the obligation of the Prison Service is formulated. The difference is so pronounced that some legal experts like Hans Reichardt do not hesitate to speak of an enforceable, subjective right to work. ${ }^{119}$ Paragraph 37, al.4 StVollzG puts the Prison Service under the obligation to provide an appropriate activity for each inmate who has not been given an occupation either in a workshop, the domestic sector, therapeutic programmes, education or professional training. According to the official application instruction (Verwaltungsvorschrift zum Strafvollzugsgesetz), an activity is appropriate when it creates value, and if the result is proportional to the effort required, in short, if it is a work activity in the current sense of the term. It differs however from "profitable prison labour" ( $\$ 37$, al. 2 StVollzG) in two ways: first, the expectations as to income generation are lower. The only requirement is an increase in the value of the product, not profit. Second, the inmate cannot insist that the activity correspond to his qualifications or wishes. On the part of the administration, its

117 Art. 717-3, al. 2 CPP; $\S 37$, al. 2 and 4 StVollzG. In England, the obligation can be in part implied from the requirement to provide inmates 24 hours per week with a purposeful activity (key performance indicator concerning purposeful activities).

118 Art. D. 101 CPP.

119 Reichardt (1999), Recht auf Arbeit. 
obligation to provide a work-related activity for each inmate is unconditional: there is no clause "if possible" or "economic conditions permitting".

This right to an appropriate activity goes back a long way. The Imperial Penal Code of 1871 already contained the following instructions: "Convicted inmates may be occupied in prison in a manner corresponding to their ability and situation. At their request they have to be occupied in this way." 120 This last clause was admittedly never put to the test, as the number of inmates without employment was negligible. The commission of experts convened to prepare a new prison law in 1976 recommended to maintain the right to an appropriate activity. Parliament followed their lead and included the obligation to provide such an activity in the new Strafvollzugsgesetz as a safety valve for inmates who otherwise risked staying locked up in their cells. The literal, historical and contextual interpretation of the text points thus clearly to an enforceable right to work but, so far, the courts have remained silent on the question and, without their backing, the right to work remains as virtual as in the other two countries.

\section{The right to be paid}

Unlike the right to work, the right to a stipend has been recognized by all three legislations, ${ }^{121}$ but with certain variants. There are considerable national differences in the pay level, its calculation, mandatory deductions, and the right of inmates to dispose of their income.

\section{a) The level of pay}

Inmates are better paid in France than in England or Germany. In our sample, the average weekly pay for 30 hours of work in industry in France is $€ 115$. The rate for domestic jobs is lower, $€ 40$ to 50 per week, but it is exempt from deductions for workers' contribution (12.5 per cent). German inmates work longer (38.5 hours) for a smaller pay: about $€ 60$ in workshops, and $€ 30$ to 40 in the domestic sector, but their mandatory contributions are much lower: 3.2 per cent. In England, the weekly wage for our sample varied from $€ 16$ in Prison Industries' workshops to $€ 96$ for Private Finance Industries' contracts, averaging at about $€ 25$ for a slightly shorter work week (20-30 hours). The minimum rate for Prison Industries that is set by the Prison Service is still lower, barely $€ 12$ (£7.50). Domestic workers are paid be-

120 Strafgesetzbuch für das Deutsche Reich, § 16, al.2, in effect from 1871 to 1969. Quoted in Reichardt (1999), p. 30.

121 Art. 717-3, al. 4 CPP in conjunction with Art. D. 102 and D. 105, al. 3 CPP; $\S 43$, in conjunction with 200 (1) StVollG; Prison Rule 31 (6). 
tween $€ 7$ and 14 per week, depending on the skills required and the hours worked. Given the low level of pay, there are no mandatory contributions.

Until January 2003, French inmates working in production had to contribute to their upkeep at the weekly rate of $€ 11.50$. Following a recommendation of the Loridant Report, ${ }^{122}$ this provision applies now only to inmates working outside prison under a contract of employment. English and German services do not practice such deductions, albeit their prison laws contain provisions to that effect. In Germany, the relatively low levels of pay make such deductions impracticable as other claims have priority, such as family obligations, contributions to the mandatory release fund or money set aside for free use in prison ( $\$ 50 \mathrm{StVollzG})$. The provisions do however apply to inmates working outside under a contract and to self-employed prisoners. In England, the Prisoners' Earnings Act voted in 1996 includes mandatory contributions toward the cost of upkeep for all inmates receiving enhanced wages, ${ }^{123}$ but as the necessary amendment to the Prison Rules and the Prison Service Orders are still in the making, these contributions are not yet deductible. ${ }^{124}$

\section{b) The basis of calculation}

The way the pay scale is calculated reveals profoundly different attitudes between the three countries. In England, the sum is still close to the old system of paying inmates some form of pocket money, and the difference between the weekly $£ 3$ granted to unemployed inmates and the standard $£ 7.50$ paid in Prison Industries' workshops is not enormous. Why did the Prison Service decide on a basic industrial wage of $£ 7.50$ and not of $£ 6$ or $£ 10$ ? There seems to be no obvious scale such as, for instance, a percentage of minimal wages. In all likelihood, the sum simply evolved from the symbolic pay of earlier days to the present level. ${ }^{125}$ This basic rate fixes however only the lower limit of the pay scale. Governors may increase the amount, productivity or the contracts negotiated with external contractors permitting.

In France, the pay scale is tied to the current minimal wage for unskilled labour and, exceptionally, to a comparable outside salary for skilled work. For the French version of private prisons ${ }^{126}$ a minimum pay rate (SMR, Seuil minimum de remuneration) has been imposed. On 1 January 2005 it was $€ 3.27$ per hour for local prisons and $€ 3.44$ in long-term establishments, which corresponds to 41 to 44 per

\footnotetext{
122 Rapport Loridant (2002), p. 99.

123 I.e., inmates working in one of the few Private Finance Industries' workshops.

124 Vagg /Smartt (1999), in: Van Zyl Smit/Dünkel (eds.) p. 68; Leech (2006), p. 490.

125 Even as late as 1990, the recommended pay for Prison Industries was £2.65 (approximately $€ 4$ ) per week.

126 In these so-called établissements à gestion déléguée several functions, among those of work and training, have been contracted out to private enterprise.
} 
cent of the minimum wage. Since 1998, the same rate applies to traditional prisons. Inmates working in the domestic sector are not paid by the hour but by the day, and the rate varies between $€ 6.60$ for cleaning jobs and $€ 11.85$ for the headcook or specialized maintenance tasks. Even if prisoners' rights associations decry wages that are not even half of minimum wage, the French Prison Service is considerably more generous than the other two.

Germany has chosen a different approach. Instead of basing the pay scale on statutory minimum wage, ${ }^{127}$ it uses a percentage of the average salary of all persons contributing to the national pension scheme. During the planning stage for a new prison law in the early 1970s, it was generally agreed upon that the old system of "tipping" inmate workers should be abandoned in favour of a proper wage structure. Taking the income of the contributors to the pension scheme as their basic value, the government commission proposed that wages be gradually increased to 40 per cent of this amount. ${ }^{128}$ The Finance Ministers of the Länder promptly vetoed the project as unsustainable and proposed instead an initial rate of 5 per cent that would gradually rise by $1980 .{ }^{129}$ But this date passed without increase, the Finance Ministers pleading that the economic context did not allow for extra expenses, at least not for prisoners' wages. Without the intervention of the Federal Constitutional Court 18 years later, the wages would probably still be at the initial low levels. In its decision (1 July 1998), the Court made it clear that the rate of 5 per cent did not conform to the principle of rehabilitation anchored in the Constitution, in particular in the notion of Sozialstaat, i.e., a State having a particular duty toward its weaker members. The Court based its decision on the following argument: "The work that a prisoner is compelled to do in prison is an effective method of resocialisation only if the work performed is given proper recognition. This recognition does not necessarily have to be financial. It must, however, be capable of demonstrating to the prisoner, by the tangible advantage it offers, the value of regular work for a responsible and crime-free life in the future."130 The court gave the Länder until 31 December 2000 to translate this "appropriate appreciation" into concrete terms. If by that time no agreement was reached, the courts (Strafvollstreckungskammern) would provide their own evaluation for each case brought before them. The Federal Ministry of Justice proposed an increase from 5 per cent to 15 per cent or, alternatively, an increase to 10 per cent with an added bonus of 1 day of sentence reduction per week of work, that is of almost 2 months per year. ${ }^{131}$

127 There is as yet no statutory minimum wage in Germany. Its introduction is however under discussion.

128 Special commission for the government proposals (Sonderausschuss zum Regierungsentgwurf). For more details see: Lohmann (2002), p. 46 f.

$129 \S 200$ (2) StVollzG.

130 BverfGE 98, 169, p. 242, cited in Dünkel (1999) in: van Zyl Smit/Dünkel (eds.), p. 82.

131 Pörsken (2001), NK, p.5-6; Ullenbruch (2000), ZRP Heft 5, p. 179. 
The first proposal was immediately rejected by the finance ministers as too costly. According to calculations made by the Bavarian Ministry of Justice, each percentage would have meant an additional 1.67 million euro per year for Bavaria alone, or 16.7 million for an increase from 5 per cent to 15 per cent. The second proposal was more interesting from a purely economic point of view. The Federal Ministry of Justice calculated that the expected "good time" would reduce the inmate population by 4084 inmates per year, which would largely cover the extra expenses of the pay increase. ${ }^{132}$ This proposal was also turned down because a sentence reduction of such proportions was deemed problematic for two reasons: 1) It went against the principle of equality, as the reduction was not applicable to inmates with indeterminate sentences, and 2) it was incompatible with provisions of the criminal code that link all forms of early release to the behaviour of the inmate and to the risk factor involved.

Under the imminent threat of having an "appropriate appreciation" imposed case by case by the courts, the Länder reached a last minute compromise ten days before the deadline imposed by the Constitutional Court. Sentenced inmates ${ }^{133}$ were to receive an increase of 80 per cent, from 5 percent to 9 per cent of the basic reference value ${ }^{134}$, and a non-monetary bonus of one day off for every two months of work ( $§ 43$ new StVollzG). Inmates can use these days as paid "vacation" inside prison or, if they qualify, convert them into day release, or accumulate them to advance their release date. It remains to be seen if an increase to 9 per cent and "good time" of 6 days per year is sufficient to create an appropriate appreciation of the value of honest work.

c) The range of pay and its repartition

Opinions vary as to whether it is right that some prisoners should earn considerably more than others. France accepts substantial pay differences for workshops run by outside contractors. The most extreme case I came across was a difference of $€ 1400$ between the lowest and the highest monthly salary. ${ }^{135}$ The Loridant Report estimates "that for inmates paid piece rates the pay difference varies between $€ 100$ and $€ 1000$ per month." 136 These disparities are well accepted by the workers as long as they are warranted by different levels of effort and skills. More problematic are inequalities between workshops that are based solely on the more or less advantageous contract negotiated with the outside firm. This difficulty does not

\footnotetext{
132 Lückemann (2002), ZfStrVo, nº 2, p. 121-122.

133 Prisoners on remand and minors are excluded from the increase and still receive only 5 per cent of the reference value.

134 In 2006,9 per cent of the reference value corresponded to a daily rate of $€ 10.58$.

135 See below, part III, chap.1, I C 2.

136 Rapport Loridant (2002), p.28.
} 
arise in prison run workshops or for domestic work where inmates are paid an hourly or daily rate, differentiated only on the basis of the skills required.

German sensitivities do not tolerate a big range in inmate salaries. The pay scale, divided into five fixed categories, is based strictly on the skill level and the degree of responsibility required, from sweeping floors to designing turbines. ${ }^{137}$ The only element of flexibility is provided by a system of bonuses. This German method has the great quality of basing differences in income on objective criteria, but it has the disadvantage of not giving sufficient weight to individual effort. An inmate, who works fast and conscientiously and could easily double the assigned quota, is penalized because the bonuses are blocked at $140 \%$ of the agreed quantity. ${ }^{138}$

In England, the question of differences in pay levels did not arise as long as the wages were uniformly low. The introduction of enhanced pay in some prisons has changed this situation. In one of the prisons I visited, inmates who lived up to certain behavioural and professional standards, could apply for allocation to a Private Finance Industries' workshop, where they could earn up to eight times more than in prison-run workshops. Inmates working in lower paid jobs are understandably upset with this dual system, the more so as their work may require higher skill levels, in engineering for instance, and access to better paid jobs is virtually closed to them.

Inmates are not always free to dispose of the money earned as they please. Countries differ in the way mandatory repartitions are regulated. English inmates are the only ones not subject to mandatory deductions or savings, as the low pay level does not allow for any leeway. This will change, at least for the prisoners earning enhanced wages, as soon as the Prisoners' Earnings Act is implemented. ${ }^{139}$

137 The federal regulation pertaining to prisoners' pay established the following categories for 2007:

I. €7.92/day: low-skilled tasks, can be learnt by simple demonstration. The pay corresponds to $75 \%$ of the average pay. Example: sweeper.

II. €9.29/day: slightly more demanding work, training period on the job from 1 to 3 weeks. The pay corresponds to $88 \%$ of the average pay. Example: sewing a straight seem.

III. $€ 10.56 /$ day: medium skilled work, training period of at least 3 weeks. The average pay is based on this category $(100 \%)$. Example: cook without vocational qualifications.

IV. $€ 11.83$ /day: skilled work requiring vocational qualifications. The pay corresponds to $112 \%$ of the average pay. Example: skilled carpenter.

V. $€ 13.09 /$ day: work requiring specialized qualification and a higher degree of responsibility. The pay corresponds to $124 \%$ of the average pay. Example: restorer of ancient books.

The pay scale for therapeutic workshops corresponds to $75 \%$ of category I.

138 This limit of $140 \%$ is based on the application instructions (Verwaltungsvorschriften) for $\S 37$.

139 Vagg/Smartt (1999), in: van Zyl Smit/Dünkel (eds.), p. 60. 
In France, mandatory deductions affect all salaries, even the relatively low ones in the domestic sector, as long as the monthly gross income exceeds $€ 200$. Ten per cent is deposited into a savings account to be used as a starting fund after release, and another 20 to 30 percent, depending on the income, is taken off to compensate victims, pay court fees and cover alimony payments. These sums cannot be seized by other creditors. ${ }^{140}$ Inmates can dispose freely only over the remaining amount.

The new German legislation is even more radical: only 3/7 of the earnings are left at the disposal of the prisoner (Hausgeld) to buy items at the prison shop or "other things" ( $\$ 47 \mathrm{StVollzG}$ ). The remaining $4 / 7$ serve to accumulate a release fund, ${ }^{141}$ and to cover alimony payments, court costs and compensation payments to victims. Should there be a surplus, it will be deposited, together with outside cash, on a special account (Eigengeld), open to seizure by creditors ( $\$ 52 \mathrm{StVollzG).}$

\section{d) The notion of "appropriate wages"}

We are still left with the problem of how to define the concept of appropriate or just wages. We know what they are not. Lord Woolf quotes in his report numerous associations, including the association of governors, that deem unacceptable pay rates which will not even cover the most immediate needs of "the poorest prisoners of Europe." 142 The German Constitutional Court has declared 5 per cent of average outside wages ( $€ 100$ to 120 per month) to be unconstitutional. The French Loridant Report considers $€ 160$ to 200 barely enough to pay for the personal monthly needs of inmates. But this does not help us to establish in positive terms the level of a fair wage. Let us go back instead to the criteria established by the German Constitutional Court: "[Work] must be capable of demonstrating to the prisoner, by the tangible advantage it offers, the value of regular work for a responsible and crime-free life in the future." If the highest German court had not established this causal connection between the level of pay and a positive attitude toward work, the idea might seem naïve. The majority of inmates need no convincing of the value of a job on the outside. ${ }^{143}$ As for the other inmates, even 40 per cent of an outside salary would hardly affect their outlook. The factors that block successful resettlement have less to do with a lack of appreciation for the importance of work than with problems encountered when leaving prison: insufficient funds, difficulties in finding work and shelter, and trouble with creditors. It is in this context that a more generous pay scheme could play a vital role. German authors ${ }^{144}$ estimate that the

140 Art. D. 320-1, al.3 (nouveau) CPP; Rapport Loridant (2002), p. 33.

141 The release fund has to be sufficiently large to cover the expenses for the inmate and his family during the first month, until payments by the social services can be activated.

142 Woolf Report (1991), p. 391.

143 Hammerschick/Pilgram/Riesenfelder (1997), in: Hammerschick/ Pilgram (eds.), p. 176 ; Simon (1999), p. 157.

144 Ullenbruch (2000), ZRP. Heft 5, p. 181; Dünkel (1998), NK, p. 14; Wrage (1997), ZRP, p. 435-436; others like Kamann (1999), in: de Boor/Frisch/Rhode (eds.), p. 349-349, 
minimum monthly prison wage that would enable inmates to reduce their debts, ${ }^{145}$ take care of their own needs and those of their families, and to get through the first months after release would be in the range of 20 to 25 per cent of an outside salary, that is between $€ 440$ to 550 per month. The same authors argue that non-monetary compensation in the form of good time would have to be one day per week, as proposed by the Federal Ministry of Justice. This might work in France, which has a virtually automatic system of sentence reduction for good behaviour, but it is not compatible with either English or German provisions for early release, and has very little chance of being seriously considered.

During the deliberations of the Constitutional Court, Judge Kruis disagreed with his colleagues on a link between appropriate wages and the appreciation of the value of work. For him, "the existential essence of man is put in question if he is exposed to a system where a fair relationship between work and reward is in principle excluded."146 In other words, human dignity requires that the pay rate of inmates should be appropriate, quite independently of any considerations of rehabilitation. In the Judge's opinion, inmates' wages should correspond as closely as possible to those outside by taking into account "the reduced productivity levels of prison labour, the lack of rationalisation practiced in prisons, its distance from external markets, and the competition of cheaper foreign labour." 147

Austria has based its reform of inmates' wages (1993) on similar criteria, taking as reference value a comparable outside salary, reduced by 10 to 40 per cent on account of lower productivity. Of the remainder, 75 per cent is taken as contribution towards upkeep. The net "take home pay" comes thus to roughly 20 per cent of external salaries - the minimum required by German authors. But this amount is still far removed from a normalised pay structure and also probably from the expectations of Judge Kruis.

\section{B. The protection of workers}

Prison laws have been more generous in insuring the protection of the prisoners at work than in granting them rights. This protection concerns both working conditions and inclusion in social benefit schemes.

As far as working conditions are concerned, all three legislative acts have adopted most of the norms applied outside, such as working hours, Sunday rest,

put the bar higher at $40 \%$. Neu (1998), NK $\mathrm{n}^{\circ} 4$, p. 16 , is the only one to consider $10 \%$ already sufficient.

145 The Bundesarbeitsgemeinschaft für Straffälligenhilfe e.V. estimates that the average debt of inmates amounts to between $€ 12,500$ and $€ 22,500$ (1993, p. 174). Even Neu, who is generally prudent, puts the average at $€ 5000$ to $€ 15,000$ (1995, ZfStrVo, p. 149).

146 BverfGE 98, 163, p. 217.

147 Ibid. 
and health and safety regulations. The latter are not always rigorously respected but substantial progress has been made over the last decade. This is particularly noticeable in Germany where in each prison one member of staff is exclusively in charge of supervising strict adherence to safety norms. Germany is also the only country to grant its inmate workers three weeks of paid "vacation".

In some respects, working conditions in prison are better than on the outside: effective work time of 32 hours or less, moderate pace, and minimal sanctions for shoddy work or unprofessional behaviour. If the Prison Service can be criticised, it is not for driving its inmate workers too hard, but rather for not asking enough and not preparing them for the demands of a competitive labour market.

National differences are more pronounced when we examine benefits. From 1946 on, France began to extend social benefits to inmate workers, from accident insurance to maternity benefits. ${ }^{148}$ Still, the protective network remains incomplete, as some indemnities inmates may have received before incarceration are suspended or reduced while in prison. ${ }^{149}$ Other benefits are only partly granted or are altogether missing: there is no compensation for days lost because of a work related accident or illness, and there are no unemployment rights, either during imprisonment or after release.

The German provisions are similar to the French ones, with the difference that German inmates are covered by unemployment insurance, but Parliament has deferred indefinitely their inclusion into the general health care plan and the pension scheme. ${ }^{150}$ This last aspect creates considerable hardship for long-term inmates who may find themselves after many years of work in prison without a pension fund and without much hope of finding a job. The chances that pension rights will eventually be extended are slim, since the Constitutional Court, in the same 1998 decision dealing with prisoners' pay, stated that there is no provision in the German Constitution that would oblige Parliament to extend all or even part of social benefits to inmates. Art. 20 I of the Constitution confers the obligation on the legislating bodies to implement a social system and institute social benefits, but the nature and the extent of these benefits as well as the range of beneficiaries are left to the discretion of the two houses, as long as the elementary needs of citizens are met. As for the pension scheme, the Court was of the opinion that there was no violation of the principle of equality (Art. 31), because the different pay structure set prison labour sufficiently apart from outside work to warrant a separate treatment. The low pay rate would not give access to a decent pension except if calculations were based on a fictitious income. German inmates are covered, however, by unem-

148 For more specific information see: Danti-Juan (1993), in: Pradel (ed.), in particular p. 106-111; Zakine (1982), Revue pénitentiaire et de droit pénal, p. 267-282.

149 For example, indemnities for older workers, for single mothers or for invalidity. Auvergnon/Guillemain (2006), p. $98 \mathrm{f}$.

150 Dünkel (2002), in: Céré (ed.), p. 216. 
ployment insurance ( $\S 26$, no.4 SGB III). The inmates' contribution is paid by the Prison Service on a fictitious basis of 90 per cent of the average income of all persons contributing to the federal pension scheme. In 2006, the average income was $€ 30,207 .{ }^{151}$ Unemployment payments can only be claimed after leaving prison and only under certain conditions: the ex-prisoner must be actively looking for work, i.e., he must be signed up with the employment bureau (Arbeitsamt) and have worked in prison for at least 12 months. Benefit payment is calculated on the average salary paid for a job corresponding to the qualifications and professional experience of the claimant. A former inmate, who has worked in maintenance and is looking for a construction job, would thus receive 60 per cent of the salary of an unskilled worker. ${ }^{152}$

English inmates are decidedly worse off than French or German prisoners as far as social security is concerned. Although they have access to medical treatment in prison, are given a small allowance of about $€ 5$ while waiting for a job placement, and some release money if they are indigent, they are excluded from all benefits linked to a contract of employment. It is not clear whether this is because work, in the perception of Parliament, is still closely linked to punishment or whether it is considered, like education and training, a privilege that need not be enhanced by further benefits. Whatever the reason, England falls below the standards of other European countries.

Table 9 : Social Benefits

\begin{tabular}{|l|l|l|l|}
\hline $\begin{array}{l}\text { Benefits apply- } \\
\text { ing to all in- } \\
\text { mates }\end{array}$ & FRANCE & GERMANY & ENGLAND \\
\hline $\begin{array}{l}\text { Health plan and } \\
\text { maternity bene- } \\
\text { fits }\end{array}$ & $\begin{array}{l}\text { Health care inside } \\
\text { prison is provided } \\
\text { by a local hospital } \\
\text { that sends its } \\
\text { medical staff to } \\
\text { prison }\end{array}$ & $\begin{array}{l}\text { Medical staff are part of } \\
\text { prison staff }\end{array}$ & $\begin{array}{l}\text { Medical staff are part of } \\
\text { prison staff }\end{array}$ \\
\hline $\begin{array}{l}\text { Minimal pay for } \\
\text { indigent } \\
\text { mates }\end{array}$ & None & $\begin{array}{l}\text { Pocket money for in- } \\
\text { mates on the waiting list } \\
\text { for job allocation }\end{array}$ & $\begin{array}{l}\text { Pocket money for inmates } \\
\text { on the waiting list for job } \\
\text { allocation }\end{array}$ \\
\hline
\end{tabular}

151 Federal Statistical Office of Germany.

152 For more information on the topic see: Hardes (2001), ZfStVo, p. 139-141. 


\begin{tabular}{|l|l|l|l|}
\hline $\begin{array}{l}\text { Work-specific } \\
\text { benefits }\end{array}$ & \multicolumn{1}{|c|}{ FRANCE } & GERMANY & ENGLAND \\
\hline $\begin{array}{l}\text { Work related } \\
\text { accident and } \\
\text { illness }\end{array}$ & $\begin{array}{l}\text { Yes, but without } \\
\text { compensation } \\
\text { payments for days } \\
\text { lost }\end{array}$ & $\begin{array}{l}\text { Yes, with compensation } \\
\text { payments }(80 \% \text { of the } \\
\text { average wage })\end{array}$ & $\begin{array}{l}\text { None, except if inmate can } \\
\text { prove negligence on the } \\
\text { part of the administration. } \\
\text { Voluntary indemnity pay- } \\
\text { ments by Prison Service }\end{array}$ \\
\hline $\begin{array}{l}\text { Pension plan } \\
\text { nefits }\end{array}$ & Yes & No & No \\
\hline $\begin{array}{l}\text { Unemployment } \\
\text { insurance }\end{array}$ & $\begin{array}{l}\text { No, and also no } \\
\text { indemnities for } \\
\text { lay-offs inside } \\
\text { prison }\end{array}$ & $\begin{array}{l}\text { Yes, if laid off in prison } \\
\text { for technical or eco- } \\
\text { nomic reasons, inmates } \\
\text { receive temporarily 33\% } \\
\text { of their former pay }\end{array}$ & $\begin{array}{l}\text { No, but indemnity pay- } \\
\text { ments for short periods of } \\
\text { lay-offs }\end{array}$ \\
\hline
\end{tabular}

To sum up: The legal status of inmates at work remains ambiguous, but in all three countries, health and safety regulations as well as working conditions are reasonably close to outside standards. The French and German social security network offers a fair coverage, but the application of individual and collective rights is deficient. The introduction of a modified contract of employment seems more likely in France as Parliamentary commissions and even the Prison Service have declared themselves in favour of extending employment rights in prison. Should such legislation be passed, it will in all probability be a "light" form of employment law, but it will nevertheless confer real rights. ${ }^{153}$ At a French high security prison a private contractor has already introduced on his own initiative a range of benefits for inmates working in his sound studios: vacation pay, job security, and training. In another high security prison, this time in Germany, the biggest outside firm involved uses a form of employment contract that gives inmates access to training, promotion and fringe benefits. A work contract for inmates is already part of the revised Belgian Prison Law. In short, there are clear signs of a greater openness to normalising not only working conditions but also the legal rights and protections of inmate workers.

153 Auvergnon/Guillemain (2006), p.175. 



\section{Part III: Work and Training in Nine Prisons}

In part II of our study, I compared the legal frameworks of prison labour. Two opposing trends emerged: on the one hand, policy makers and prison administrators want to harmonise working conditions with the conditions of the outside world in order for work to become an efficient tool for reintegration; on the other hand, increased concerns over security and budgetary problems make this harmonisation difficult.

In the third part, the practical impact of these two competing trends will be examined in three long-term prisons in each country. Chapter one will offer a summary of the different work and training options offered in each prison, and chapter two will present the inmates' view of work. At the outset, I shall say a few words about the method.

\section{Chapter 1: Nine Prisons - Nine worlds}

\section{Method of Inquiry}

In order to provide a realistic picture of work in the nine prisons, it seemed best to use all the sources and resources available: direct observation of work places, semi-structured interviews with inmates, less formal conversations with staff and, finally, a questionnaire handed out to roughly $25 \%$ of working prisoners.

\section{The choice of establishment}

As far as the choice of the prisons was concerned, only establishments corresponding to the following four criteria were considered:

1) Long-term establishments receiving convicted offenders sentenced to a minimum of three years. Work in local prisons (maisons d'arrêt; Untersuchungsgefängnisse oder Kurzstrafenvollzugsanstalten) and work in long-term establishments face different challenges that call for different solutions. As I could not cover both types, I chose the second one. The same constraint of feasibility led to the exclusion of prisons for women and young persons under 18 years of age. ${ }^{154}$

154 The reasons for choosing long-term establishments over short-term ones are explained in the introduction, p. 3. 
Within long-term prisons, I wished to represent:

2) Different levels of security, ${ }^{155}$ based on the assumption that the more an establishment concentrates on security, the heavier are the constraints on work.

3) Geographical location, a key factor for the success of any firm, inside or outside prison. I chose, in each country, a prison in or near an urban centre, a second one in an industrial area with a good infrastructure, and a third in a more remote region.

4) Workshop organisation. The two principal types, prison-run industries and contract work, are both represented.

I did not attempt a comparison of traditional establishments with private or semiprivate prisons, because the vast majority of German Länder remain opposed to the transfer of state functions to the private sector in this area. The first private prisons were opened in Hesse and in Baden-Württemberg less than two years ago.

The Prison Services suggested several establishments in the light of these four criteria. The following were selected:

In France, the maison centrale (MC) d'Ensisheim, located in the prosperous and industrialised area of Alsace (predominance of contract firms); the MC de Poissy, situated in the heart of the town of Poissy on the outskirts of Paris (mixed organisation: Prison Industries and contract firms); the centre de détention (CD) de Montmédy, of recent construction in one of the poorer regions of France (outside contracts, managed by central Prison Industries).

In Germany, the Justizvollzugsanstalt (JVA) Straubing, a top security establishment in a prosperous small town in lower Bavaria (mixed organisation); the JVA Kaisheim, a detention centre for recidivists (cat. C) in a rural area of Bavaria with little industrial activity (mixed organisation with a predominance of Prison Industries); the JVA Schwalmstadt in Hesse, a cat. B training centre in the historical heart of a small town in proximity to the industrial basin of Frankfurt (mixed organisation).

In England, Her Majesty's Prison (HMP) Frankland, a dispersal (category A) prison in a rural area in the North of England (mixed organisation: Prison Industries, outside contracts and work for associations); HMP Swaleside, a category B training prison on the Isle of Sheppey near to docks and the industrial area of Kent (predominance of private finance enterprise); HMP Featherstone, a category $\mathrm{C}$ prison designed in the 1970 s as an industrial prison, on the outskirts of Wolver-

155 Category A, B and C prisons according to the English model, or maisons centrales and centres de detention according to the French structure. 
hampton, an industrial town in the West Midlands (predominance of Prison Industries).

\section{The Inquiry}

The inquiry followed roughly the same pattern in all the prisons. An initial meeting with the director of the establishment and/or his deputy in charge of work was followed by meetings with the workshop manager and, in England and Germany, with the industrial manager. Two days were generally spent in visiting workshop and other work or training sites during which I was able to talk freely to the members of staff and the inmates. These visits allowed me to distribute a questionnaire that addressed the following topics: description of the work (nature, hours, remuneration); previous professional experience; motivation; satisfaction; productivity; assessment of the link between the present activity and professional reintegration after release; suggestions for improving work in prison. I was aiming for a random sample covering all proposed activities (domestic duties, Prison Industries, concession workshops, cell work), and a ratio of questionnaires filled by $20 \%$ of the working population, i.e., 50 to 60 questionnaires for the bigger establishments of 400 inmates or more. The analysis of the questionnaires revealed that the sample was not as balanced as one could have wished for, because the random selection was compromised by the fact that it automatically excluded the illiterate and many foreigners who did not master the written language. Furthermore, the number of participants in two establishments, Montmédy and Swaleside, fell below the required threshold. ${ }^{156}$ In both cases there was no feedback from inmates assigned to domestic work.

Semi-directive interviews ${ }^{157}$ with five working inmates and five without a job placement took the better part of the other two days. Lasting for about an hour each, the interviews gave me a better understanding of the concerns of working inmates and the effects of unemployment in an environment where unemployment and poverty often go hand in hand. The industrial or workshop manager and a senior prison officer normally selected the inmates for the interview. They chose "interesting guys who had something to say," but it was nonetheless a varied and balanced selection.

I also attended meetings related to work, such as job allocation commissions, budget meetings, Hauskonferenzen (meetings of a section or block) in Germany, and sentence plan meetings. I had less formal interviews with persons directly or indirectly involved with work: workshop and industrial managers, governors, ac-

156 Montmédy: 14 questionnaires $=10$ per cent of the working population; Swaleside: 20 questionnaires $=5$ per cent of the working population.

157 I.e., interviews that are structured by precise questions but that leave ample scope for the interviewee to express his opinion. 
countants, instructors in charge of education and the sports centre, psychologists, social workers and, occasionally, with the clergy looking after the unemployed.

A week was barely enough. It sufficed to get a good idea of the range of work and training options available in each prison, and of the degree of satisfaction expressed by inmates and staff. It also allowed for some insight into the challenges and difficulties faced by management and workers. But it was not long enough to make an in-depth assessment of internal problems not readily revealed to someone coming from the outside.

I had not anticipated the degree of interest, even of eagerness displayed by inmates and staff to discuss various aspects of work. Obviously I was dependent to a great extent on the goodwill of the director and on the co-operation of the work managers. The latter had to spend a lot of time showing me around, setting up appointments, and explaining the economic and material organisation of work. Without their help, my research could not have been carried out, and I would like to take this opportunity to express my deep gratitude to all of them.

We will begin our survey with the French prisons, followed by the German and English establishments.

\section{The French Establishments}

\section{A. The maison centrale of Ensisheim}

\section{General information about the establishment}

The maison centrale (MC) is located in the industrial basin of Alsace in the heart of the ancient Hapsburg town of Ensisheim. It is one of the six high security prisons in France, and accommodates 200 to 220 inmates condemned to long sentences. ${ }^{158}$

The building was originally a Jesuit College that was transformed into an arms and powder depot during the French Revolution, and then converted into an asylum for mental patients. During the first French Empire, in 1811, it became one of the first maisons centrales de force et de correction, i.e., a prison under central government control. It has since undergone substantial renovations: buildings were added for workshops, offices, an infirmary, an education block and a gym.

The first priority of a category A prison is security, and Ensisheim is no exception to the rule. This is not without influence on prison labour: work is seen as an important way of keeping a potentially explosive population under control, but its major aim, professional reintegration, is of no immediate concern.

$15891.6 \%$ serve a sentence for more than 10 years, 64 serve a life sentence, which in France usually means 18 to 30 years. 


\section{Work and training}

In 2002, 101 out of 196 inmates were working in workshops or in their cells, and 47 were employed in domestic and maintenance tasks. Exceptionally, no vocational training course was offered. The employment rate was thus 75.8 per cent, the highest of the nine prisons. In our sample, the average weekly pay amounted to €94, a figure that might be slightly misleading as earnings vary widely. Inmates working full time in the domestic sector earned from $€ 43$ to $€ 47$ net per week, whereas those allocated to better paying workshops could make up to $€ 300$ gross.

Working hours were close to the hours worked in an outside factory: $7 \frac{1 / 2}{2}$ hours per day, from 7.00 a.m. to 11.30 a.m., and from 12.45 p.m. to 4.15 p.m., but actual working time was nearer to 6 hours, if we take into account two thirty-minute breaks and the time spent on security checks.

Table 10: Paid activities at the MC Ensisheim in 2002

\begin{tabular}{|c|c|c|c|c|c|c|}
\hline Activities & $\begin{array}{l}\text { Prison In- } \\
\text { dustries }\end{array}$ & Contract shops & $\begin{array}{l}\text { Domestic } \\
\text { tasks }\end{array}$ & Vocational training & Education & Total \\
\hline $\begin{array}{l}\text { Number of } \\
\text { posts }\end{array}$ & 1.5 & 100 & 47 & $\begin{array}{l}0 \\
\text { normally } 10-20\end{array}$ & $\begin{array}{l}\text { about sixty } \\
\text { over the year }\end{array}$ & $\begin{array}{l}149 \text {, With voca- } \\
\text { tional training at } \\
\text { its usual level: } \\
164\end{array}$ \\
\hline $\begin{array}{l}\text { Percentage of } \\
\text { paid activities }\end{array}$ & $1 \%$ & $67.1 \%$ & $31.6 \%$ & $\begin{array}{l}0 \% \\
(9.1 \%)\end{array}$ & & $99.7 \%$ \\
\hline $\begin{array}{l}\text { Percentage of } \\
\text { the total popu- } \\
\text { lation (196) }\end{array}$ & $0.76 \%$ & $51 \%$ & $24 \%$ & $(7.6 \%)$ & & $\begin{array}{l}75.8 \% \\
(83.4 \%)\end{array}$ \\
\hline
\end{tabular}

Percentages between brackets take into account the vocational training in normal times.

Until 2002, job allocation was the responsibility of the deputy governor in charge of employment, who would usually delegate decision making either to the workshop manager or the senior wing officer (chef de detention) depending on the type of employment. Following PACTE 2 (second improvement plan for work and employment conditions: deuxième Plan d'Amélioration des Conditions de Travail et d'Emploi) a multi-disciplinary job allocation commission was created. It is composed of the deputy governor, the senior wing officer, the workshops manager, the head of professional training, the head of education, a psychologist, and a member of the probation and social service. It is thus hoped to better address the needs of the inmates, as each job applicant can count on finding among the members at least 
one "advocate" willing to put in a good word for him. The regular meetings enable different departments to exchange information about inmates and see them as a whole person rather than just as a worker, a student or a problem case. It also gives the workshop manager a chance to explain the needs and constraints of his workshops.

There are a few draw drawbacks as well: since the working week for staff is limited in France to 35 hours, spending two extra hours in a meeting sometimes appears a waste of precious time. Fixed weekly meetings cause a certain loss of flexibility: if a post becomes vacant in the middle of the week or if the workload increases, the job allocation will have to wait until the next meeting. Work also loses some of its control function as job allocation becomes less tied to behaviour. Personal arrangements such as: "you will get your posting on the condition that you change this or that behaviour" are no longer possible. Workshop managers complain that the needs of the workshops are no longer given priority when selecting applicants. ${ }^{159}$ Generally speaking though, the advantages outweigh the drawbacks, and inmates feel reassured and better protected against arbitrary decisions, real or imagined.

The job allocation commission also decides whether to remove workers from their jobs either for disciplinary reasons, gross incompetence, a shortage of orders or upon the request of the inmate. In the case of serious disciplinary problems, an immediate decision to remove the inmate from the workshop can be taken by the senior officer or by the workshop manager. It must then be endorsed by the job allocation commission and, if necessary, by the disciplinary commission.

All rules concerning health and safety at work are to be implemented inside the prison with the same rigour as outside. A specially appointed health and safety manager makes sure that the rules are complied with.

\section{a) Productive work}

Productive work is exclusively managed through outside contracts which, contrary to most other prisons, provide an exceptionally high number of semi-skilled and skilled tasks. The RIEP (the French equivalent of Prison Industries or Eigenbetriebe) only supplies one and a half jobs. ${ }^{160}$ The geographical location of the prison is in its favour. It is 3 kilometres from the motorway, in a prosperous industrial area, and close to the German border with opportunities for cross-border contracts. The workforce is stable with motivated inmates who want to work in order to earn

159 The criteria, in order of importance, are the following: 1. Economic situation of the applicant; 2. Date of application: how long has he been waiting for a placement? 3. Professional skills; 4 . Training and post-release project; 5 . Personality of the applicant (ability to fit into a team, for example).

160 One job as a forklift truck driver and one part-time job as a framer. 
money and would much rather be busy than stay locked up in their cells. The prison has therefore much to offer to industries wanting to outsource part of their production, but the almost full employment could not have been achieved without a constant effort by administration and workshop managers, because the prison also present drawbacks. There is lack of floor space and insufficient storage area. Access to the establishment is difficult: the gates are too narrow for bigger lorries; loading and unloading periods are limited to the opening hours of the workshops, and the security measures, i.e., roll call and searches, take up a disproportionate amount of time.

Eight firms in total have relocated part of their production to Ensisheim. Two employ between 25 and 45 inmates, another has about fifteen employees. The other contracts are smaller (between 2 and 5 inmates). I shall describe the work carried out by two firms in greater detail.

A ladder and scaffolding manufacturing firm occupies the most important area. The workshop is responsible for the complete manufacture, from cutting metal tubes to packaging and shipping the welded, painted and labelled products. The firm built the workshop out of its own funds and, therefore, considers itself entitled to take all the decisions as to its use. This is becoming an issue as the firm has reduced the number of workers from 80 to 30, and the freed up space could be used for other contracts. The inmates, who have been working there for some time, are the first to admit that things are not what they used to be. Up to 2001, they were paid by the hour and given a yearly increase. They are now paid piece rates, without a bonus for seniority, and earn considerably less than they did before: on average between $€ 133$ and $€ 171.50$ per week. The same firm used to offer paid training sessions for the more qualified tasks, welding or spray painting for instance, but this is no longer the case. In short, the work climate is deteriorating, the workforce is less motivated, and there are more and more requests for transfers to other jobs. This is a pity because the workshop reproduces the working environment of an outside firm and appeals to inmates because of its "macho" image: a job for real men who, at the end of a solid working day, come out tired and dirty and better able to cope with the long hours in their cells. ${ }^{161}$

A second firm that manufactures electrical equipment (cables, plugs, reels, etc.) has been working out of Ensisheim for several years. The owner has contracts with a few other prisons in France and Germany and displays a positive attitude towards his crew. The remuneration, even if based on piece rates, is fair: $€ 160$ to $€ 293$ gross per week, averaging at about $€ 190$. In 2002, the workshop employed 45 inmates under the supervision of a prison officer, assisted by one or two other officers. This so-called "mixed" concession system is now being phased out in France, and firms are increasingly obliged to send in their own civilian foremen. From a financial

161 The owner recently pulled out completely from his prison contract. The building stands empty until funding for renovations is approved. 
point of view, the new policy is more advantageous for the prisons, which can redeploy members of staff from workshops to proper prison-related tasks. But work supervision in prison requires more than technical know-how; a foreman also has to know how to deal with a sometimes explosive workforce. Not all civilian foremen have the relational skills or the motivation for this kind of job. I somehow got the impression that some firms intentionally relegated their less capable staff to prison workshops. A more flexible solution might allow the use of prison officers as instructors while charging their wages to the firms. ${ }^{162}$

Workers give the second workshop a high rating. They like their jobs, which are varied, demand speed, co-ordination, and a good sense of teamwork. With thirty years experience, the instructor considers that working in a workshop is like a breath of fresh air in the closed prison universe, one of the rare places where initiative and problem solving capacities are truly appreciated. Seen in this light, work plays an important role by preserving and developing attitudes that are sought after in the outside world but often neglected or even discouraged inside. The officerinstructor is less optimistic about the chances of professional re-integration because few firms are willing to give a chance to someone who has spent time behind bars, whatever his qualifications. The manager of the contracting firm made it clear from the outset that he does not consider hiring his prison employees after they have been released.

\section{b) Tertiary work}

Until recently, three inmates were keying in computer entries for an outside firm. This contract has not been renewed, mainly because the three computer specialists had no Internet access, and communication took too long. Only one of the three is still employed part-time by a historical society.

c) Housekeeping and maintenance duties

Forty-seven inmates, i.e., 31 per cent of the working population and 24 per cent of the total population, are allocated to general domestic duties, a generic label that covers a wide range of activities: cleaning, kitchen, laundry, food distribution, maintenance, but also tasks of barber, librarian and even letter writer. The new policy demands that most of these jobs be full-time, with a minimum wage of $€ 40$ per week, but Ensisheim has maintained a few part-time jobs in order to enable those who wish to study to retain financial independence, as taking courses in prison is not remunerated in France. Newcomers are usually allocated to this sector during their first year.

162 Prison officers cannot be paid directly by private firms, but some solution could be worked out by increasing the concession fee. 
d) Vocational Training

Vocational training inside a high security prison is not an easy matter, and even less so in France where the teaching is still based on the conventional school model that leads up to a high school certificate (CAP/BEP vocational certificates). Candidates, in order to be eligible, need a decent educational background and sufficient social skills to fit in with classmates over a period of one to two years. Ideally, training should take place at an appropriate moment, preferably near the end of the sentence or close to parole (a date that is notoriously uncertain). Then there is the issue of training options: the qualifications offered should be useful when looking for a job after release, but they have to be of a kind that can be practiced inside prison. Finally there is, as always, the problem of funding. Normally, one or two training courses are offered each year but none were available at the time of our inquiry. During the past few years, Ensisheim had offered a CAP certificate in institutional cooking and a university course in computer application (DU Crami). Computers are important in this prison: 120 inmates out of 200 have a personal computer in their cells. While there is a strong interest in this diploma, the number of candidates fulfilling the prerequisites is too small to offer it regularly. Unfortunately, funds have been refused for the more basic certificate in computer science (BTS informatique). Another popular diploma course is a warehousing certificate (CAP magasinage) that combines computer skills (stock management) with practical qualifications, such as driving forklift trucks. A new project would recognize the professional experiences of each inmate by establishing a "passport" that would list all the tasks he is able to perform, thus conferring a certain value and a reward for efforts made inside the prison.

\section{Comments}

At Ensisheim, work is virtually the only means inmates have of preparing their return to society. The small number of therapeutic programmes is insufficient to cover the needs of the population. Full-time education has a limited appeal, as there is no financial bonus attached to it. Even if most classes take place after work, many workers are by then too tired to make the effort to attend. The planned introduction of a continuous working day ending at 3 p.m. would no doubt enable inmates to make better use of the excellent educational facilities. Vocational training plays a secondary role, as in other high security prisons, especially in those with a high employment rate. If the local staff had a free hand, training schemes would be more numerous and diversified, e.g., in the field of construction. The main problem is funding: within the restricted training budget of the Prison Service, dispersal prisons rarely make it to the top of the priority list.

As far as workshops are concerned, Ensisheim offers a variety of semi-skilled jobs. Its paid activity rate of 75.5 per cent is more than respectable, but the rate of 
unmet job applications remains high at 20.5 per cent. This creates a problem, given that there are few alternative activities. The administration tries to compensate for the shortage of places in productive work by increasing the number of jobs in the service sector (31.6 per cent of total jobs). Such a solution is preferable to unemployment but is not ideal. Both administration and staff have made proposals to increase the number of productive jobs. These include changing the funding scheme so that part of the profits earned could be used by the establishment to cover the necessary investments, hiring a part-time computer specialist as an Internet intermediary to boost the contracts in the computer sector, and rebuilding the prison on a bigger plot of land with spacious and functional work areas. It seems unlikely that this last proposal will be received in the near future, but the others are well within reach.

The latest statistics (May 2007) show some changes for the better, some for the worse. The prison population has dropped from 196 to 163.43 inmates are allocated to domestic duties (down from 47), and 58 work in contractor workshops (down from 100, mainly due to the closing of the ladder manufacture). Full time professional training is up to 19, and another 22 workers are acquiring skills certifications (bilan des compétences) while working. The paid activity rate has remained virtually the same: 74.2 per cent compared to 75.8 per cent in 2002 .

\section{B. The maison centrale of Poissy}

\section{General information about the establishment}

Poissy prison is located in an ancient Abbey in the historical centre of the town of Poissy, just a few kilometres from Paris. It is linked to the capital by commuter trains and combines all the advantages of a good infrastructure and a privileged location in the densely industrialized area of the Ile de France.

Its population varies between 220 and 230 inmates. In 2002, the number had exceptionally fallen to 188 , due to a riot a few weeks earlier and the ensuing transfer of the prisoners held responsible. Poissy is less centred on security than Ensisheim as many inmates are sent there at the end of their sentence. ${ }^{163}$ This policy has an impact on the age of the population: in $2001,56 \%$ of all inmates were over 40 years and only $44 \%$ in the 21 to 40 years age bracket.

Workshop space is just as restricted as at Ensisheim, and a rational organisation of the floor space is even more difficult. The riot in early 2002 did not help matters: the classrooms, the library and the kitchens were completely destroyed, and part of the living quarters was damaged.

163 Le Caisne (2000), p.345. 


\section{Work and training}

During my visit, 100 out of 188 inmates were working: 55 were employed in workshops and 45 in domestic tasks. The only on-going professional training course, in catering, had been suspended following the riot. Thus, the very low paid activities rate (53.1 per cent) was not representative of the normal situation.

Table 11: Paid activities at the maison centrale of Poissy

\begin{tabular}{|l|l|l|l|l|l|l|}
\hline Activities & $\begin{array}{l}\text { Prison } \\
\text { Industries }\end{array}$ & $\begin{array}{l}\text { Contract } \\
\text { workshops }\end{array}$ & $\begin{array}{l}\text { Domestic } \\
\text { tasks }\end{array}$ & Vocational training & Education & Total \\
\hline $\begin{array}{l}\text { Number of } \\
\text { inmates }\end{array}$ & 15 & 40 & 45 & $\begin{array}{l}\text { None, but normally } \\
\text { around 20 }\end{array}$ & 114 in 2001 & 120 \\
\hline $\begin{array}{l}\text { Percentage of } \\
\text { paid activi- } \\
\text { ties }\end{array}$ & $12.5 \%$ & $33.3 \%$ & $37.5 \%$ & & & $100 \%$ \\
\hline $\begin{array}{l}\text { Percentage of } \\
\text { the total } \\
\text { population } \\
(188 \text { inmates }\end{array}$ & $7.9 \%$ & $21.3 \%$ & $23.9 \%$ & & & $\mathbf{5 3 . 1 \%}$ \\
\hline
\end{tabular}

The annual prison report covering this period (April 2001 to April 2002) indicated that the employment rate (53.1 per cent) had begun to already slide before the riot. ${ }^{164}$ Two factors may be held responsible: first, a new set of directives aiming at fewer domestic tasks, and better paid jobs; second, a desire to ensure regular and full time employment for those retained in workshops. Surprisingly, there was no waiting list for the workshops, and the GEPSA ${ }^{165}$ group complained about an acute shortage of workers. The few job applications were all for domestic duties. The average weekly pay for our sample was $€ 81.60$.

In the productive sector, working hours were from 8.00 a.m. to $11.15 \mathrm{a} . \mathrm{m}$. and 1.00 p.m. to 4.00 p.m., roughly six hours per day. Domestic workers often worked fewer hours but were still paid a lump sum for a hypothetical workday of six hours.

Since 2003, job allocation is the responsibility of a classification commission that has the same composition as in Ensisheim.

164 Source: Annual Report 2002 of MC Poissy.

165 GEPSA is a private company specialising in contract work for inmates. It is in charge of the work sector in $40 \%$ of mixed management establishments, but its services are increasingly requested by traditional prisons. 


\section{a) Productive work}

Poissy's workshops offer a wide range of jobs. Two are managed by the RIEP (Prison Industries), and another two by GEPSA, a company specializing in contract work for prisons. The other contracts are minor, involving only a few inmates. The establishment tries to diversify the types of work in order to cater for all categories of applicants. Four inmates are self-employed and work for associations or authorised companies.

Two workshops for digitising sound and photographic archives are now run by the RIEP for the contractor who started them. Both are excellent and warrant being presented in detail.

The Sound Studios have been developed in prison through the initiative of the contractor, Nicolas Frize. Convinced of the necessity of giving inmates meaningful work, Frize started two projects combining work, training and creative activities. In his philosophy, work should target the whole person: it should enable growth through creative expressions, responsible behaviour and forethought. But interesting work by itself is not enough: in order to really rehabilitate, it has to go hand in hand with recognized employment rights. In addition to the normal contract agreed upon with the establishment, a second contract is signed between the entrepreneur and each worker who thereby becomes entitled to most rights provided for by a regular employment contract: paid leave, health insurance, wage and job security during periods of sickness, and minimum wage. The only rights that are excluded are collective rights such as that to strike. ${ }^{166}$ These commitments on the part of the contractor are not legally binding, as art. 717-3, al 3 CPP expressly excludes binding contracts between employers and inmate workers, but Frize honours them as if they were. They thus acquire a great symbolic value.

The work consists of digitising national archives, and is subcontracted through the National Audio Visual Institute (Institut National Audiovisuel - INA) in collaboration with the French Ministry of Culture. The aim is to preserve historical documents, such as political speeches, war programmes, musical recordings, photographs, historical texts, and so on. Selection for training is strict but all school levels are considered. The initial training on sound recording is given at another high security prison, Saint-Maur. This lasts two to three months, and is followed by an in-service training programme of three further months at Poissy, where the trainees learn to transcribe sound files onto CDs. This work demands a high degree of concentration that cannot be sustained indefinitely; each member of the team is therefore given a "sabbatical month" per year, during which he is free to devote himself to his own creative work. ${ }^{167}$ Each worker must be able to perform every operation, as there is no outside foreman, a role that is taken over by inmates who

166 Interview with Nicolas Frize, Dedans-Dehors, Nov.1997, p. 12.

167 During that month, remuneration is equal to the pay during the training period. 
act as team leaders, each for a period of two months. In 2002, seven inmates were employed in three sound studios, a number that has since doubled. The monthly pay is around $€ 473$.

The photo and text studio (8 computer specialists) deals with the digitising of photos and texts, but also processes documents for the prison administration and accepts contracts from private companies, to do mailing catalogues, for example. The training is given on the premises. The monthly remuneration varies between $€ 580$ and 670 per month.

In the course of my research, I had the opportunity to attend the weekly meeting between Nicolas Frize and the sound workshop team, an encounter that was very different from what one might expect to find in a prison setting. There was no question of a boss imposing his orders and controlling the work but of a leader discussing the week's work with a motivated team. This collegial approach had an obvious impact not only on the quality of the work but also on the well being of the workers. The most telling testimony came from a member of the team who said that working in the sound studio had not only changed but also saved his life. He had reached a point in his sentence when suicide seemed the only option remaining. Just then, at the moment of his deepest crisis, he was offered a training place for sound digitising. There was no miracle cure - self esteem is not rebuilt overnight but he slowly began to discover that he was able to handle a demanding job, that he did have unexpected creative talents and that even in prison it was possible to master one's own life. He also realized that he was not alone, that there were people ready to take a risk with him and to support him in difficult moments. As he put it in the interview: "This changed everything for me and I started to hope that even for me there might be still a future." It is no surprise therefore that the Loridant Report ${ }^{168}$ singles out these two studios as models to emulate.

If the studios under Prison Industries management portray work at its best, the same cannot be said of the workshops relying on outside contracts, apart from one exception, a chandelier manufacture that offers three inmates on the job training, interesting work and a decent monthly salary (€540). ${ }^{169}$ The other contracts concern unskilled tasks (assembling electrical cables, gluing joints, or sorting out onions according to size) paid at piece rate. Some contractors pay reasonable wages. Others, among them GEPSA, do not do so, and inmates have to make do with an average wage of $€ 190$ per month, just slightly more than a cleaner who earns $€ 166.20$. This low pay rate is odd considering that the establishment aims at an av-

\footnotetext{
168 Rapport Loridant (2002), p. 68-69.

169 This remuneration is higher than the one paid in the 'sound' workshop (€473) but considerably below that earned in the 'photo' workshop (€553).
} 
erage hourly rate of $€ 4.27 .{ }^{170}$ Most likely inmates do not work full-time, but are only called when there is work available.

b) Maintenance and domestic duties

45 inmates are allocated to domestic duties. In accordance with the new directives of the Prison Service, the average weekly pay has been increased to a minimum of $€ 40$ and the number of part-time jobs reduced. The percentage of inmates working in housekeeping still remains exceptionally large (37.5 per cent of all jobs).

\section{c) Self-employment}

The one area that is slow in getting off the ground is self-employment. Only 4 inmates in Poissy have managed to get the necessary authorisation, all of them for computer work.

\section{d) Training}

In 2001, before the riot, 102 inmates had been registered for professional training in the broadest sense of the word, including courses for the illiterate or preparatory courses to bring students up to the required entry level for professional training. The pay, based on an hourly rate of $€ 1.99$, was considered hardly competitive as compared to wages proposed in the workshops. ${ }^{171}$ New directives in 2006 have lowered this rate even further and in certain cases suppressed the remuneration altogether.

There are several training options. Particularly popular is an apprenticeship in $\mathrm{ca}$ tering offered over a one-year period for candidates with a good academic background or over two years for those who do not have the required prerequisites. This second possibility gives a chance to inmates who would otherwise be excluded from acquiring professional qualifications. Also in demand are computer studies at various levels, training for sound and photo digitalising, and on the job training in chandelier assembly.

\section{Comments}

The Poissy prison has many positive assets. Its location on the outskirts of Paris allows easy access for contractors and outside personnel. The inmate population is relatively mature and stable. The administration does its best to set up training programmes that appeal to a variety of inmates, and aims at supplying work of good quality. Yet such jobs (in the two studios and in the chandelier manufacture) only

170 Annual Report of the establishment for 2001.

171 Ibid. 
involve 18 out of 184 inmates. Attempts to increase this kind of employment are hampered by the factors already noted in Ensisheim, in particular the lack of spacious, modern workshops. It is almost impossible to increase the floor space at Poissy, which is cramped into historical premises in the centre of the town. We cannot even speak of a workshop area as such. The workshops are scattered in different locations, and this complicates the movement of inmates, and renders their supervision more difficult.

Unlike Ensisheim, Poissy does not have solidly established production workshops. It must therefore make do with contractors who use the prison workforce when it is convenient and leave as soon as the economic situation worsens. This is why the administration resorts to groups such as GEPSA that provide jobs that are low paying, monotonous, and with no openings on the outside market.

The latest statistics (May 2007) ${ }^{172}$ show an improvement in the overall employment rate from 63.7 per cent to 67.3 per cent, despite an increase in the population to 230 . The two studios have increased their work places to twenty, and there are ten more jobs in the contract sector. However, the number of job seekers has not increased.

\section{The centre de detention of Montmédy}

\section{General information about the establishment}

Montmédy is a category $\mathrm{C}$ prison for inmates serving long sentences (between 12 and 20 years). Of recent construction (1988-90), it can accommodate up to 310 inmates. At the time of our inquiry the actual number was 292, with slightly over half of the inmates convicted for sex offences. This explains to some extent the unusually high average age of the population (42 years).

Building a new prison in one of the poorest rural areas of France only makes sense when seen as a political decision to create jobs in a disadvantaged region. From a resettlement point of view the site offers very few advantages. Its weak infrastructure and its distance from urban centres prevent frequent family visits and reduce the availability of outside specialists such as psychologists and teachers. It also makes it difficult to obtain contracts for the workshops. Even recruiting staff has turned out to be a problem; two key positions in the work and training areas could not be filled. Otherwise, the prison regime is exemplary and tries to alleviate the drawbacks related to the location. It is the most liberal of all prisons that I have seen, whether in France, Germany or England. Cell doors are open from 7.30 a.m. to 7.30 p.m., and the inmates can move freely in all non-restricted areas. Those

172 Statistics of the Regional Directorate for Prison Services, May 2007: population: 230; Vocational training: 25; Domestic duties: 45; RIEP: 25; Concession: 55; Work for an association: 5. Total: 155 . Ratio of paid activities: $67 \%$. 
with a job go to work on their own. They are allowed a five-minute margin for arriving late, after which they are locked out. This less constraining approach pays off. The atmosphere is more relaxed and the staff-inmate relationship is friendlier. In 2001, there was one suicide recorded but no incident of violence.

\section{Work and training}

In spite of its location, Montmédy has something to offer to firms that want to relocate part of their production. It has a separate, spacious and modern workshop area of approximately 2000 square meters, and a mature and motivated workforce. ${ }^{173}$ Furthermore, all workshops obtained their ISO 9002 certification in 1998. At that time, the detention centre was often quoted as a prime example of a prison having managed to overcome the obstacles linked to its location. It had attracted ten companies, eight of which had the same ISO 9002 certification and were looking for a partner that could offer the same standards. Unfortunately, an economic downturn and organisational problems have changed the situation. In the summer 2001, the establishment was forced to call upon the RIEP (Prison Industries) to take over the management of the workshops. The RIEP normally only runs its own workshops in prisons where there is a shortage of employment. Managing outside contracts in an establishment with which it had no previous contacts was a novelty, but the best solution in this case. The RIEP is specialised in prison work, has commercial contacts and experience in commercial practices. ${ }^{174}$ This frees the governor from economic and organisational responsibility for work, and lets him concentrate on his main functions. The only problem is that this new system creates two hierarchies, as is already the case in the French semi-private prisons. The RIEP is not accountable to the governor and the latter has no authority over the workshops. This is already an issue in the private establishments where mutual competencies were clearly defined from the outset. It is even more problematic at Montmédy where the new structure was put in place almost overnight. The director feels that his hands are tied in his own prison, but the RIEP too lacks the freedom of action of work managers in semi-private prisons, who can organise their workshops as they see fit and are free to hire (and to fire) their personnel. The RIEP does not have this privilege: it is fettered with existing contracts and the personnel on site. Tulle, the administrative headquarters, is $500 \mathrm{~km}$ away - too far to give efficient support to the local team.

173 The majority of inmates condemned for sex offences have held a regular job before their court case.

174 To quote but one example: before the RIEP took over the control of Montmédy, outside firms only paid the inmate's remuneration and the reduced employers social contributions. They now have to contribute to the general overhead costs for electricity, heating, etc., and to the wages of the supervisory staff. 
Table 12: Paid activities at the centre de detention of Montmédy

\begin{tabular}{|l|c|l|l|l|l|l|}
\hline Activities & Contracts, RIEP & $\begin{array}{l}\text { Domestic } \\
\text { tasks }\end{array}$ & Vocation training & $\begin{array}{l}\text { Working out } \\
\text { permits }\end{array}$ & Education & Total \\
\hline Number of jos & 55 & 38 & 29 & 2 & 97 over the & 124 \\
\hline $\begin{array}{l}\text { Percentage of } \\
\text { paid activities }\end{array}$ & $44.3 \%$ & $30.6 \%$ & $23.4 \%$ & $1.6 \%$ & & $99.9 \%$ \\
\hline $\begin{array}{l}\text { Percentage of } \\
\text { the total popu- } \\
\text { lation (292 } \\
\text { inmates) }\end{array}$ & $18.8 \%$ & $13 \%$ & $9.9 \%$ & $0.6 \%$ & $\mathbf{4 2 . 5 \%}$ \\
\hline
\end{tabular}

In 2002, 55 inmates were employed in workshops, 38 in housekeeping and maintenance, 29 were in training, and 2 had jobs outside. This corresponds to a rate of remunerated activities of $42.5 \%$ (124 out of 292). The rate of unsatisfied requests for jobs or training courses was high. At that time, 55 inmates were recorded as unemployed (inmates that had been given a job allocation but were not working), 24 inmates were on the waiting list, and 7 inmates had been dismissed but asked for another chance. This corresponds to a ratio of unmet job requests of 40.9 per cent (86 out of 210). According to the senior officer, the unfavourable impression created by those figures is not entirely justified because some of the applicants are incapable of holding down a steady job. One year later, in 2003, 175 the situation had already improved: the number of active workers had increased to 188, pushing up the paid activities rate to 64.3 per cent, with on average 68 unmet job applications or an unmet requests rate of 26.8 per cent.

The average weekly pay by the end of 2001 was $€ 77.25$, but the average calculated for the inmates who had filled in our questionnaire was slightly higher: $€ 85$. The salary bracket was particularly large, ranging from $€ 30$ per month for part-time workers to salaries in excess of $€ 1000$, the highest remuneration exceeding $€ 2065$.

Inmates in production jobs work a continuous 6 hours shift, from 7.30 a.m. to 1.30 p.m. Such a work pattern is best suited to the needs of prisoners because it enables them to share in other activities after work. It is also better for productivity as less time is wasted on security checks, and extra hours can be added in the afternoon if necessary.

175 Statistics produced by the regional Directorate. 
The job allocation commission had not been set up in 2002. Decisions for job allocations, both for domestic duties and for workshops, were made by the senior officer on the basis of the choice expressed by the applicant; his financial situation (priority being given to the poor), and his abilities.

\section{a) Productive work}

Under the management of the RIEP, productive work still depends entirely on concession contracts. Eight to ten companies supply various assembly and mounting jobs. Most tasks can be learnt in a matter of days; only the manufacture of plaster of Paris moulds for the Museums of France requires a slightly longer training period. At the end of 2001, the post of employment manager was vacant and the whole organisation and supervision of the work was given to two prison officers employed by the RIEP. This was a heavy load for two men without particular business or management training, and more so as they also had to deal with the paperwork of the ISO 9002 certification. The establishment had an ISO 9002 specialist on its staff but his day was taken up by compiling files and he did not consider supervision of the practical implementation of quality standards as part of his job. To make matters worse, the two instructors could not rely on the support from the administrative staff of the RIEP, because the deputy director in charge of quality and the local representative had left and had not been replaced. Even before the introduction of the 35 hours workweek, the tasks linked to quality certification could not be managed without resorting to overtime. With the new law, that converts overtime automatically into days off, it became impossible for the two officers to keep up. The administrative tasks required for the ISO 9002 certification were more and more neglected and, as a consequence, the certification was not renewed in 2002. ${ }^{176}$ This was a hard blow, as most companies had chosen Montmédy mainly because it offered the required quality standards, and had no intention of renewing their contract without those guarantees. The loss was also painful for the workers, many of them older and highly motivated.

Most of the jobs are dull: packaging of hardware, welding, assembly and mounting of tin pieces, assembly and mounting of wooden boxes, plaster moulding, repackaging of car accessories, etc. The equipment, like the skill level, is minimal: old-fashioned hydraulic presses and welding material, a furnace to dry the plaster mouldings, a forklift truck and some manual palettes.

Operators are responsible for the quality of their work. Packaged products bear their prison number and the production date. An error can therefore be traced and corrected (without extra pay). The best workers can be promoted to foremen, and be in charge of training newcomers, co-ordinating teamwork and supervising the

176 It was re-established in 2004, once the RIEP was well established and the vacant posts filled. 
work process. The foreman I interviewed felt strongly that this was an unrewarding job. He had to deal with the envy of his teammates, and received no compensation in the form of privileges and moral authority enjoyed by civilian foremen.

b) Domestic duties and maintenance

The service jobs are divided into two categories. First class workers, such as the technical team and the head cooks, receive a daily remuneration of $€ 9.15$, whereas the second category must be content with $€ 6.40 .{ }^{177}$ The number of jobs varies between 38 and 48, according to needs. In summer, the maintenance of the grounds requires more manpower (5-10 workers); in winter, interior maintenance (painting, electricity) is more important.

c) External job placements

Inmates nearing the end of their sentence and in possession of an outside work permit can be allocated jobs outside the walls. There are two forms of such placements: either they can work under the supervision of prison staff for a public body or association, for instance in park maintenance or, alternatively, the judge can grant a proper job placement. In this latter case, inmates work under the supervision of the employer with whom they have signed a regular contract of employment. Nevertheless, they are still part of the prison population and remain under the authority of the governor who can end the contract at any time should the courtimposed conditions be violated. In 2002, only two inmates were placed in outside jobs.

\section{d) Training}

Inmates have the choice between three kinds of courses: 1) Training in horticulture leading to vocational qualifications. This is open to 18 inmates eligible for release in the near future, and is primarily aimed at young inmates without a diploma but a few older candidates are also admitted to help stabilise the younger, less disciplined group. The training lasts one to two years according to the initial schooling level. Thanks to the trainees, the green spaces within the detention centre are impeccably kept with flower borders that would be the envy of any public park. 2) Learning through sports (4 months renewable), targeted at young people with an insufficient educational level. Their day is divided between sports (judo, football, first-level arbitration training) and the learning of basic skills. This is particularly suited to trainees, who would never set foot into a classroom were it not for the incentive of sport. 3) Training in maintenance and sanitation, a course aimed at those working in the domestic sector. In 2002, this was temporarily on hold.

177 Cooks are paid $€ 7.62$ because of the extra hours involved. 
There is general agreement that the number of training programmes is insufficient for the needs of young people with low-level key skills and little professional experience. Funding, as always, is the major obstacle.

\section{Comments}

Work in Montmédy mirrors many of the weaknesses criticised by the French Parliamentary commissions and by the more recent Loridant Report. A paid activities rate of 42.5 per cent and a rate of unmet job applications of 40.9 per cent are unacceptable in a prison centred on re-integration, all the more as Montmédy enjoyed in the past the reputation of being a prison with near full employment, in spite of its geographical location. Its positive reputation outlasted the downturn, and all the unemployed inmates that I interviewed said that they had put in a request for transfer to Montmédy especially because of the promising work prospects. It came as a great shock to them when they realized that they had been mistaken. Three quarters of the older inmates had held a steady job in the outside world and did not know how to organize themselves without work. Many also badly needed the income, since sex offenders are often rejected by their families and cannot count on outside financial support.

It is also the case that 80 per cent of the jobs in workshops and in the domestic sector do not require training, and 10 per cent only a brief apprenticeship period. A mere handful of posts need proper qualifications: 2 computer posts, that of first cook and the technical service. The machines and the tools are old models that do not prepare the inmates for professional activity outside. The loss of the ISO 9002 standard certification, that guaranteed quality and correct procedures, was the last straw. The shortage of qualified employment is not compensated by a sufficiently wide range of professional training. Even the two high security prisons of Ensisheim and Poissy do offer in normal times more options than the detention centre, in spite of the fact that their populations supposedly have a lower potential for rehabilitation.

This unsatisfactory state of affairs can be blamed on economic factors over which the prison has no control such as economic stagnation and competition from Eastern European countries. Furthermore, the transition period after the RIEP took over the workshops led to a temporary decline in the volume of work. ${ }^{178}$ There was also a shortage of key personnel, ${ }^{179}$ which meant that the energetic steps required

\footnotetext{
178 One or two concession companies had withdrawn when there was talk of them paying for supervision and general overhead costs.

179 At the beginning of 2002, the jobs of workshops manager, training manager and local RIEP representative were vacant.
} 
where not taken. Nevertheless, it is hard to understand why the RIEP did not set up one of its own production workshops in order to bring in more qualified jobs.

Since 2001, the situation has considerably improved. According to the latest statistics (May 2007), the paid activity rate is up to 65.8 per cent from the previous 42.5 per cent, in spite of a rise in the population ( +30 inmates). This positive development is mainly due to a spectacular increase in industrial jobs (+66 posts) and, to a lesser extent, in vocational training (+12 places).

\section{The German Prisons}

We begin our overview with the Justizvollzugsanstalt (JVA) Schwalmstadt in Hesse, and will then go on to the two Bavarian prisons, JVA Straubing and JVA Kaisheim.

\section{A. JVA Schwalmstad}

\section{General information about the prison}

JVA Schwalmstadt, in the Bundesland of Hesse, is located in the heart of the village of Ziegenhain-Schwalmstadt, approximately one hour away from Wiesbaden, Frankfurt and Mainz. The area is semi-rural and benefits from good infrastructure, linking it to the industrial area of Frankfurt. The prison is set in the Ziegenhain Fortress, built by the Hessian Landgraves in the $16^{\text {th }}$ century. The façade and some ancient buildings are still part of the detention centre but the extensive grounds have allowed for the construction of new living units and modern workshops.

The prison has three separate units: 1) A category B training section with 268 places in the "castle" wing (population in 2002: 301 inmates). This wing is mainly reserved for inmates serving sentences of five years or more. It is subdivided into four residential units that accommodate the various categories of inmates. 2) A detention centre for older inmates who do not pose any particular security risk, at the present some 50 prisoners. This centre does not have any production workshops, and inmates are either allocated to domestic duties or attend a therapeutic workshop. Many are already retired. 3) An open prison for 28 inmates (population: 18). Twenty years ago, this centre still accommodated close to one hundred men, sixty of whom went to work outside under regular employment contracts. The good rapport between the prison management and the neighbouring small and medium sized enterprises meant that such work allocations led to very few problems and were advantageous for all parties concerned. A new "zero risk" policy has virtually put a stop to these outside placements. This is why most of the building has been converted into the centre for older prisoners, the so-called "grandfather" prison. 


\section{Work and training}

In 2002, 83 out of 301 inmates in the main prison were working in the production workshops, 43 in domestic duties and maintenance, 43 were in training, 5 were allocated to the therapeutic workshop, and 26 were full-time students. This meant a professional activity rate of 57.8 per cent (174 out of 301 ), or of 66.4 per cent if we include the number of students who, unlike French prisoners, are paid for attending classes. Out of the 100 inmates without work, 40 per cent were exempted for health or other reasons, 40 per cent were on the waiting list. The remaining 20 per cent more or less openly refused to work. The rate of true unemployment, i.e., prisoners applying for employment without obtaining a job placement, was therefore about 16.7 per cent, i.e., 40 out of 240 . Although work is compulsory, refusal to work rarely leads to disciplinary measures because workshop managers have no interest in employing unmotivated inmates when they have at their disposal forty eager people waiting for a job. This does not mean, however, that refusal has no consequences: prisoners who refuse to work are not entitled to pocket money and are often sent to less privileged living quarters. They also have virtually no chance of benefiting from a sentence adjustment.

Table 13: Paid activities at the JVA Schwalmstadt

\begin{tabular}{|c|c|c|c|c|c|c|c|}
\hline Activities & $\begin{array}{l}\text { Prison } \\
\text { Industries }\end{array}$ & $\begin{array}{l}\text { Contract } \\
\text { workshops }\end{array}$ & Domestic tasks & $\begin{array}{l}\text { Vocational } \\
\text { training }\end{array}$ & Education & $\begin{array}{l}\text { Therapeutic } \\
\text { workshops }\end{array}$ & Total \\
\hline $\begin{array}{l}\text { Number of } \\
\text { jobs }\end{array}$ & 30 & 53 & 43 & 43 & (26) & 5 & $\begin{array}{l}174 \\
(200)\end{array}$ \\
\hline $\begin{array}{l}\text { Percentage of } \\
\text { remunerated } \\
\text { activities }\end{array}$ & $\begin{array}{l}17.2 \% \\
(15 \%)\end{array}$ & $\begin{array}{l}30.5 \% \\
\quad(26.5 \% \\
\end{array}$ & $\begin{array}{l}24.7 \% \\
(21.5 \%)\end{array}$ & $\begin{array}{l}24.7 \% \\
(21.5 \%)\end{array}$ & $(13 \%)$ & $\begin{array}{l}2.8 \% \\
(2.5 \%)\end{array}$ & $\begin{array}{l}99.9 \% \\
(100 \%)\end{array}$ \\
\hline $\begin{array}{l}\text { Percentage of } \\
\text { the total popu- } \\
\text { lation } \\
\text { (301) }\end{array}$ & $10 \%$ & $17.6 \%$ & $14.3 \%$ & $14.3 \%$ & $(8.6 \%)$ & $1.6 \%$ & $\begin{array}{l}57.8 \% \\
(66.4 \%)\end{array}$ \\
\hline
\end{tabular}

Figures in brackets include the remunerated educational activities.

The pay structure is determined by federal decree (Strafvollzugsvergütungsordnung) and is divided into five scales corresponding to different levels of training or responsibility. ${ }^{180}$ This basic pay can be increased through a bonus scheme that

180 See above, Part II, chap. 2, II, A, 2 b. 
ranges from 5 to 15 per cent. Inmates in apprenticeship programmes are comparatively well paid (category III during the first stage of their apprenticeship, category IV in the second stage, if their exam marks warrant it). The average weekly remuneration for our sample was $€ 51$.

As in the other countries, jobs are assigned upon written request from the candidates. The "house board" (Hauskonferenz) ${ }^{181}$ selects the applicants for domestic and maintenance duties. Job placements for productive jobs are decided by the workshop manager on the basis of the preferences expressed by the inmates, their skills, the period they have already been waiting, and the needs of the production units.

Inmates work continuous days from 6.45 a.m. to 3.15 p.m. This period includes breaks for breakfast in the workshop, two coffee breaks and lunch in the refectory. The hours add up to 38.5 hours - the official workweek of civil servants - but the time actually spent working is closer to the French norm of 30 to 32 hours. In the hope of reducing the cost of prison labour, a new regulation will oblige workshops to adapt the salary to the number of hours of actual work. Effective working hours are already used as the basis for the calculation of deductions in case of absence. 182

\section{a) Productive work}

Productive work gives employment to 83 inmates, i.e., to 41.5 per cent of inmates either at work or in training. Prison Industries (Eigenbetriebe) run three production workshops (engineering, carpentry and a raffia network production), and a market garden unit that occupies 25 to 30 inmates, with a theoretical work capacity of 48 places. ${ }^{183}$ Contrary to England, the production targets mainly external customers (chassis for trailers and fairground carriages; restoration of ancient cupboards, manufacture of period furniture).

The budget for the Eigenbetriebe is included in the establishment's general budget. This allows for a certain degree of flexibility, which the French RIEP lacks. Shortfalls can, exceptionally, be covered through savings in other domains, and eventual surpluses are shared between the Treasury and the establishment as a whole.

\footnotetext{
181 German establishments are subdivided into "houses". Each house is placed under the supervision of a deputy director assisted by a senior officer. House conferences take place once a week. Ex-officio members are the deputy director, the senior officer, the workshop manager, a psychologist, a social worker, sometimes the head of education and the chaplain.

182 Before the pay increase in 2001, the weekly remuneration of an inmate absent from work for two hours was reduced by $2 / 38$ th. This reduction is now of $2 / 30$ th.

183 Theoretical jobs are calculated on the basis of the work area and the available machines and tools.
} 
Most of the production jobs come from external contracts (62.6 per cent, or 52 jobs out of 83), which the prison can draw up according to needs without being tied by a standard form. In 2002, Schwalmstadt operated 8 such workshops (trophy assembly, office furniture assembly, sewing of money bags and of military accessories, manufacture of hinges, doors, fences and fence posts), the biggest employing 19 inmates, and the smallest two. Most tasks are simple and repetitive, and a single demonstration is sufficient to enable a new operator to start working (pay level I or II). Only two workshops, trophy assembly and engineering, require higher skills.

Inmates are paid piece rates (Leistungslohn), whereas workers in workshops run by the prison or in housekeeping are remunerated on an hourly basis (Zeitlohn). This system, "pay according to productivity", does not exactly match the French system of piecework rates, for the work pace is calculated on a daily basis, in other words, each inmate has to produce a certain agreed number of pieces in order to be paid a daily sum fixed according to the official hourly rates. Pieces above the agreed target are remunerated through a bonus. ${ }^{184}$

\section{b) Domestic and maintenance tasks}

At the time of our inquiry, 43 inmates (14 per cent of the total population) were working in this sector at the usual tasks: maintenance, kitchen, laundry, library, clothes exchange, distribution of meals, cleaning, and so on.

\section{c) Therapeutic workshops (Arbeitstherapie)}

The German Prison Law ( $\S 37$, al. 5) provides for the creation of therapeutic workshops for inmates who are unable to keep up with a normal work pace. JVA Schwalmstadt has two such workshops. The first is situated in the regular detention centre, the second in the unit accommodating older inmates. The focus in both is on arts and crafts such as pottery and woodwork. Ideally, participants should be gradually brought to the point where they can hold down a regular job, but the instructors of both workshops doubted that this was a realistic goal. They believed they were already achieving a great deal if they countered the negative effects of imprisonment through creative work, thereby giving the participants a sense of doing something worthwhile and useful.

In the main detention centre, the pottery workshop was not well attended in spite of its pleasant atmosphere and competent staff. It only hosted three inmates in a space conceived for eight. I was told that this was because inmates feared to be considered "nut" cases if they accepted a place in a therapeutic workshop. The level of remuneration did not help either: 75 per cent of category I, i.e., $€ 5.44$ per day.

184 For piecework rates, the following bonuses apply: 5 per cent if the pace of work is exceeded by 5-20 per cent; 10 per cent if it is exceeded by $20-30$ per cent, and 15 per cent for up to 40 per cent. 
d) Training

Training plays an important role in Schwalmstadt. 43 inmates are in full-time training programmes, as many as there are workers in the domestic and housekeeping sector. Three main apprenticeships are offered: 1. Training in the building trade: bricklaying and carpentry. This lasts between 18 and 24 months and is validated by an external examination commission. The certificate (Gesellenprüfung) corresponds to the English national vocational qualification and is recognised in the whole of Germany. In addition, inmates can opt for shorter specialization modules lasting three to four months. On average there are 16 apprentices. 2. Training in the hotel and restaurant trades (cook's certificate: 24 months; shorter modules: 3 to 4 months). 9 inmates were in full training, 3 in short modules. 3. Training in engineering for roughly 13 apprentices. The specialized diploma course in carriage and chassis manufacturing lasts 26 months. On offer is also preliminary training for inmates that have to catch up on academic skills and a complementary course in welding. All training is funded by the Federal Ministry for Employment and by two semi-private foundations. ${ }^{185}$

\section{Comments}

JVA Schwalmstadt is in many ways a model prison: it offers professional training in trades that are in demand on the outside, the workshops are well managed, and the head of work and his team are attentive to the needs of the workers. "Every man is transformed when treated as a human being."186 This motto, displayed in large script on the office wall, gives a good idea of the team's philosophy. Every morning at $6.40 \mathrm{a} . \mathrm{m}$. the workshop manager greets each inmate by name as he enters the great porch leading to the workshops. This is the time when workers with a particular concern can make them known. Before 7 a.m., the manager is already making the rounds of the workshops to check the attendance lists and to make sure that the workshops have the labour force and the material for the day's production. As his office is situated right in the production area, his presence is much more effective than in other prisons where all offices are located in the administration building.

Schwalmstadt takes first place in Hesse as for pay and bonuses. In 2002, 63 per cent of workers were classified in category III $-\mathrm{V},{ }^{187}$ and among them over 60 per cent received maximum bonuses. This has since changed following new directives

185 The Berufsfortbildungswerk Gemeinnützige Bildungseinrichtung des Deutschen Gewerksschaftsbundes GmbH and the Gefangenenbildungswerk Dr. Fritz Bauer.

186 "Der Mensch ist wie verwandelt, wenn man menschlich ihn behandelt".

187 Hessisches Ministerium der Justiz, Final report of the working group "Neuorganisation des Arbeitswesens" (2002), p. 10. 
from the Ministry of Justice: half of the workers no longer receive a bonus as "they are only doing their job." The remaining bonuses have been reduced. Jobs were reclassified to lower levels and the rules tightened. Most housekeeping jobs as well as low-skilled contract work were demoted to pay level I, i.e., 75\% of the basic salary. Non-productive periods, such as coffee breaks or leaves taken for other activities, have been cut down to a minimum, and the time to get to the workshops is no longer counted as working time. These measures were presented as in the best interest of the inmates, in order to prepare them "for the tough world of work outside." From the inmates' point of view, they were a mere ploy to take back some of their pay increase imposed on the Länder by the Constitutional Court. These cuts thus fostered a sense of injustice and did little to increase productivity. They achieved, however, considerable savings for the treasury.

Other proposals are more positive. A study commission on job creation ${ }^{188}$ suggested the creation of a "Competence Centre", a central planning bureau that would take care of advertising prison products and coordinating their production among several establishments. This would help alleviate Schwalmstadt's most urgent problem: the creation of more jobs. Unfortunately, the closed prison perimeter precludes the expansion of workshops, even if more contracts could be found.

The latest statistics (June 2007) indicate a noticeable decrease in the number of Prison Industries jobs (down to 16 from 30). Outside contracts are also less plentiful and provide now 46 jobs compared to 53 in 2002. Inmates working in the domestic sector, including laundry, kitchen, works and gardens are, however, up from 43 to 70, those in full time professional training have increased to 47, and the number of prisoners attending the therapeutic workshop has more than doubled (from 5 to 11). One may regret the loss of industrial jobs, but thanks to increased employment in the other sectors the work and training rate has risen from 57.8 per cent to 62.1 per cent (190 places for 306 inmates). The open prison has been closed, and working out from JVA Schwalmstadt during the last part of the sentence has become a thing of the past.

\section{B. JVA Straubing}

\section{General information on the establishment}

JVA Straubing, Bavaria's most secure long-term prison, was built roughly one hundred years ago, in 1902. ${ }^{189}$ New buildings were later added (a hospital, a psychiatric wing, workshops, sports facilities, etc.), the old buildings have been com-

\footnotetext{
188 Hessisches Ministerium der Justiz, Final report of the working group "Erhöhung der Beschäftigungsquote" (2002).

189 Built on the Pentonville model (radial construction), it was at the time considered one of the most up to date prisons in the Reich.
} 
pletely refurbished, and the outer perimeter reinforced. ${ }^{190}$ JVA Straubing is a functional, modern and, above all, very secure prison establishment. It is situated on a twelve-hectare terrain on the outskirts of the Bavarian town of Straubing on the shores of the river Danube. Although the area cannot properly be described as industrial, it boasts a good infrastructure (road, train and river) and is generally prosperous.

In 2002, the prison counted 864 inmates of whom 200 were lifers and 51 were serving a so-called security measure added at the end of their initial sentence. ${ }^{191}$ The vast majority of inmates serve five years or more. The staff-inmate ratio is high, almost one to two, partly because of high security requirements, partly because of the specialized services offered. Inmates are allocated to different wings according to their status (new admissions, first offenders, repeat offenders, young prisoners and prisoners in training, prisoners awaiting trial with special security requirements, prisoners to be released within two years, prisoners with psychiatric problems and, finally, prisoners needing hospital care). Most are given individual cells, but there are also 30 community cells housing 8 to 10 inmates.

\section{Work and Training}

JVA Straubing can provide jobs for about 586 of its 864 inmates. This corresponds to an employment rate of 67.82 per cent. Of the 220 inmates who are without work, 36 are in full-time education, about 50 are excused from working because of illness or old age, and between 140 to 150 are waiting for a job opening. Inmates on the waiting list are given pocket money and have the right to two exercise periods a day. Except for activity time in the evenings and on weekends, very few alternatives are open to them and they remain locked up for the greater part of the day. The conditions of the small group of prisoners openly refusing to work are even more unpleasant: they are given no pocket money, and their exercise period is reduced to one a day. In other words, they are locked up twenty hours from twentyfour.

190 The prison is surrounded by a 6 meter high double wall, guarded by six watchtowers.

191 The so-called Sicherungsverwahrung is a preventive measure which, in some way, can be compared to the Californian three strikes model with the difference that it is imposed at the end of a determinate sentence and is, in theory, not a punishment but a measure to protect the public from potentially dangerous offenders. 
Table 14: Paid activities at JVA Straubing

\begin{tabular}{|l|l|l|l|l|l|l|l|}
\hline Activities & $\begin{array}{l}\text { Prison } \\
\text { Industries }\end{array}$ & $\begin{array}{l}\text { Contract } \\
\text { workshops }\end{array}$ & $\begin{array}{l}\text { Domestic } \\
\text { tasks }\end{array}$ & $\begin{array}{l}\text { Vocational } \\
\text { training }\end{array}$ & Education & $\begin{array}{l}\text { Therapeutic } \\
\text { workshops }\end{array}$ & Total \\
\hline $\begin{array}{l}\text { Number of } \\
\text { jobs }\end{array}$ & 171 & 241 & 125 & 35 & $(36)$ & 14 & 586 \\
\hline $\begin{array}{l}\text { Percentage of } \\
\text { total paid ac- } \\
\text { tivities }\end{array}$ & $29.1 \%$ & $41.1 \%$ & $21.3 \%$ & $6 \%$ & $622)$ \\
\hline $\begin{array}{l}(27.5 \%) \\
\text { the population }\end{array}$ & $(38.7 \%)$ & $(20.1 \%)$ & $(5.6 \%)$ & $(5.8 \%)$ & $(2.2 \%)$ & $99.9 \%$ \\
$(864)$ & $19.8 \%$ & $27.9 \%$ & $14.5 \%$ & $4 \%$ & $(4.2 \%)$ & $1.6 \%$ & $\mathbf{6 7 . 8 \%}$ \\
\hline
\end{tabular}

Figures in brackets include the remunerated educational activities.

The pay scale, as we have seen for Schwalmstadt, is the same for the whole of Germany, the only leverage given to the Länder being the bonuses. As in Hesse, bonuses were cut after January 2001 in order to absorb some of the extra cost caused by the increase in prisoners' salaries. The average pay of our sample was $€ 66.10$, compared to $€ 51$ in Schwalmstadt and $€ 62.20$ in Kaisheim.

Allocation procedures are similar to those in Schwalmstadt. Inmates make a written request, indicating their preferences. If possible, the head of industries tries to accommodate them but the needs of the workshops and the perceived abilities of the inmate come first. A change of workshop can be requested after a few months, but inmates, especially if they work well, are strongly encouraged to stay in the same job. Domestic and maintenance work is allocated by the Hauskonferenz or wing board. ${ }^{192}$

Health and safety standards are meticulously observed. A staff position was created to deal exclusively with health and safety aspects and to ensure that all workplaces conform to the norms.

\section{a) The workshops}

In 2002, 206 inmates (46 per cent) worked for Prison Industries in 21 different workshops, and 241 (54 per cent) for 7 private companies. The normal workweek is 38.5 hours, from $6.50 \mathrm{a} . \mathrm{m}$. to $11.45 \mathrm{a} . \mathrm{m}$. and 1.00 p.m. to 3.40 p.m. Monday to Thursday, and from 6.50 a.m. to 12.35 on Friday.

192 Its composition is the same as in Hesse: an assistant governor, usually a lawyer, a senior prison officer, a psychologist, the workshop manager and a social worker. Other staff (doctors, teachers) will be consulted, if necessary. 
The 21 Prison Industry workshops produce the customary prison goods, from furniture to clothing. What distinguishes them from French or English Prison Industries is the strong emphasis on outside contracts, public or private. It goes without saying that these contracts are essential for financial reasons, but they are equally important because they provide a variety of tasks required for training apprentices and more stimulating work in general. I will describe two of these workshops in some detail to convey a better idea of the variety and quality of the work.

The computer furniture workshop (18 inmates, two to three instructors) is a new venture and one of the showcases of Bavarian Prison Industries. It was created mainly through local staff initiative and offers a custom tailored service from design to installation of every type of computer furniture. The customers at present are mainly institutional (police, ministries, local governments) but it is hoped to attract a private clientele. The equipment can match that of any outside firm and so do the quality requirements. Inmates are well aware of theses advantages to judge by the waiting list for a job allocation. The only difficulty is to find two or three experienced workers who are sufficiently close to the end of their sentence to be granted a working out permit in order that they may help with the assembly at the final destination. Training is on the job only, as the workshop has been conceived as a pure production unit.

The bookbinding workshop employs 19 workers including 5 apprentices supervised by one master binder. The work ranges from binding printed materials (professional journals, volumes for archives, agendas, etc.) to the restoration of ancient books for libraries. The shop also has a framing department that makes museum quality picture frames and luxury photo albums, and a repair section for old leather goods such as doctor's bags or briefcases. The pride of the workshop is the restoration of ancient books, a field in which it works in direct competition with the State Library (Staatsbibliothek) in Munich. The quality of work is said to be the same but the delays are much shorter (two years for the Staatsbibliothek, one year at Straubing). Not many inmates have the inclination or the talent to work in this specialized field, but the ones who do have excellent chances on the job market when they come out.

The impressive variety of semi-skilled and skilled jobs available in Prison Industries is also found in some of the contract workshops. Work in four out of the seven is as low skilled and repetitive as in most other prisons (packaging of spare parts for a car manufacturer or the assembly of plastic toys), but three companies have outsourced more specialised production lines to prison. A small workshop (5 to 6 workers) produces wrestling and judo mats made to Olympic standards, which are shipped directly from Straubing to as far as Japan and Australia. All inmates receive top wage (category $\mathrm{V}$ ), and the productivity is correspondingly high for 
prison standards: about $60 \%$ of what would be expected of outside workers, compared to $15-20 \% 193$ in regular workshops. Inmates are trained on the job. They have the possibility of a proper apprenticeship in upholstery but this would mean a pay cut (category III) and is not seen as an attractive alternative. A second workshop, employing 31 workers, produces riding saddles. It requires skilled leatherwork but this can be learned on the job. The two workshops have several elements in common: both produce quality goods with a high added value and both require sewing skills but, contrary to tailor shops, they avoid the stigma of being perceived as women's work. Both pay top wages. On the downside, there are very few related job openings outside, and German inmates are not usually attracted by this kind of work. The saddle shop is almost entirely staffed with foreigners, who, in the words of the instructor, "are more gifted to work with leather."

The third workshop fulfils all the criteria of an ideal prison job: skilled work with a future, good training, adequate pay and agreeable working conditions. A large German engineering firm maintains a modern production plant, which produces component parts for airplane engines, and operates a tool polishing shop, a welding and lathe turning shop and a CAD design office. Altogether it employs 86 inmates, supervised by 10 external employees. The prison only provides two prison officers for security. The company offers a two-year apprenticeship in metal engineering, and shorter training courses in welding, construction programming and design. Workers who have obtained the welding pass may weld actual turbine parts. This is worth mentioning, as the second Bavarian prison in our sample, JVA Kaisheim, tried in vain to convince a neighbouring helicopter plant to outsource some of its production. This firm considered the risk of shoddy prison work in a highly sensitive field too high. The attitude of the engineering company working out of JVA Straubing is therefore all the more remarkable: inmates who have been carefully selected, are well trained, motivated by good working conditions and supervised by competent staff are thought to work every bit as well and as productively as outside workers. The company uses several strategies to increase motivation: the workers are better paid than in any other workshop: on top of their category $\mathrm{V}$ remuneration they receive an extra $€ 1.50$ per day, paid into their release account. There are other perks like free coffee vouchers or lunch taken in common. Just as important is the prestige that goes with the job, and the possibility to be hired by the company after release. In exchange, inmates have to sign a contract with the company pledging to stay in the job for a minimum of two years to warrant the investment in training time.

193 This percentage was calculated by Axel Neu in his various studies on the economic aspects of prison labour. See, for instance, in Kawamura/Reindl (eds.) (1998), p. 114. The rate, which may appear excessively low, was confirmed by the Bavarian Ministry of Justice. 
The workshop manager admits that his company did not choose Straubing out of a social conscience but because it seemed a good investment. The more qualified the job, the more attractive are prison wages compared to what the company would have to pay outside workers. But making a profit and providing decent jobs are not mutually exclusive, and the company is a definite asset to the prison. If this were not the case, the governor would not have made several concessions to prison routine. The inmates work, for instance, in two shifts, from 5.15 a.m. to 7.00 p.m., and they work every second Saturday. This means extra shifts for the prison officers who have to get them out early and bring them back late, and different schedules for breakfast and dinner. As no interruption of work for visits or appointments are allowed, these have to be scheduled after hours. Lunch is brought to the shop to save half an hour of unnecessary going back and forth to the cellblock with its associated security checks. Such arrangements were rendered possible because the company started working inside Straubing 35 years ago, at a time when the prison population was smaller and the routine less inflexible.

b) Domestic tasks, maintenance, laundry and kitchen

125 inmates, i.e., 22 per cent of all employed prisoners, take care of domestic tasks (68), ground maintenance (12) and the two big service departments: laundry (16) and kitchen (29). This percentage is relatively low. On the positive side it means that the vast majority of working inmates are given productive jobs, but it also signals a certain unwillingness on the part of the administration to reduce unemployment by increasing the number of domestic jobs. The official policy is to employ no more than 10 per cent of the total prison population or roughly 24 per cent of the working population in this sector.

Domestic workers stay on in their jobs well beyond the statutory three months, presumably because turnover in the industrial workshops is discouraged and openings therefore scarce.

\section{c) Therapeutic workshop}

The therapeutic workshop provides creative activities for 14 patients of the psychiatric hospital. Straubing is the only prison in Bavaria to offer psychiatric facilities in a secure setting, and if a prison cannot cope with a troubled inmate, he is sent to Straubing for a few months. Part of the therapy consists in getting the inmates used to a structured activity that will give them a sense of achievement. Patients paint, for instance, wooden toys or other objects. The work is creative and pleasant, and what they produce is in great demand at the annual fair of Straubing, where inmates can exhibit and sell their handiwork. ${ }^{194}$ In working with troubled inmates, the hu-

194 This event, which coincides with the annual fair of the town of Straubing, is exceptional as the prison holds an "open house" during two whole days. The gym is converted into an exhibition hall where visitors are invited to buy whatever the prisoners have crafted 
man qualities of instructors are particularly important. At Straubing, as in the other therapeutic workshops I visited in Germany, the dedication of the staff (usually prison officers) was truly impressive. If they had a say they would extend access to the workshop to the growing number of regular inmates who need some form of therapeutic work to help them make the transition to a regular job.

\section{d) Professional training}

Straubing offers 55 places for full-time, two-year vocational training in a variety of fields. ${ }^{195}$ Despite these interesting and varied options, only 35 places are filled on average. Before beginning the training, some inmates have to catch up on basic academic skills (mathematics, German, and technical drawing), and they can replace one day of work per week with a full school day without loss of pay. If they so choose, they can also opt for a grade nine leaving certificate (Hauptschulabschluss), following an intensive six months course.

\section{Comments}

Straubing is often quoted as an outstanding example in the field of prison labour. Her Majesty's Chief Inspector of Prisons, Judge Stephen Tumim, was so impressed by the workshops when he visited Bavaria in 1995 that he strongly recommended the adoption of the Straubing model in England. ${ }^{196}$ What most impressed the then Chief Inspector was the substantial profit made by the various prison enterprises: close to two million euros in 1995. The figures for 2000 are similar: $€ 2,113,698$. The figures for $2001(€ 1,573,981)$ are still impressive but somewhat lower as higher labour costs and a downturn in the economy have taken their toll.

These figures have been contested by two British researchers, Fulton and Smartt, ${ }^{197}$ who claim that the net profit would be greatly reduced were proper accounting methods applied. The criticised method (kameralistischeBuchführung) has now been replaced by a system that takes into account such factors as the depreciation of equipment, light, heating, and staff salaries, with the exceptions of the salaries of the head of work and the officer-instructors that appear at only 20 per cent of the real cost. ${ }^{198}$ But even if the profit were less impressive than indicated,

in their spare time: pictures, birdhouses, handmade chess games, toys. Gifted and productive inmates can earn more in two days than in several months in the prison workshops.

195 Baker, butcher, cook, bookbinder, printer, carpenter, electrician, gas fitter and plumber, gardener, tailor, media designer, car mechanic, painter, bricklayer, radio and television engineer, central heating and ventilation technician, technical draughtsman.

196 Smartt (1996), Prison Service Journal, № 106, p. 7.

197 Fulton/Smartt (1996), Prison Service Journal, No 103, p. 2-5.

198 Art. 22.1.3.4, Arbeitsverwaltungsordnung für die Justizvollzugsanstalten in Bayern (AVO). 
Straubing still offers the largest proportion of skilled jobs in any of the nine research prisons, and it boasts the greatest number of workshops run on properly commercial lines. This pronounced commercial orientation is already noticeable during labour allocation: new arrivals with professional skills are immediately set to work, whereas the less gifted may have to wait a long time. The management style of most workshops differs too from that normally encountered in Prison Industries: instructors are not only allowed but expected and encouraged to find outside customers, and they are given the means and the time to do so. This link with the outside is crucial. It obliges the workshops to offer the same standards of quality, service and delivery, as would an outside firm. By the same token it gives the inmates a chance to work under conditions similar to those they will meet outside. It adds variety to the work and makes instructors more inclined to delegate responsibilities to their workers. The model of a private engineering plant with high standards inside prison helps to create a different work culture. Of course, not all workshops in Straubing are run along theses lines. This would neither be practicable nor desirable given some of the limitations of the available manpower. Many inmates, as in other prisons, have not held steady jobs prior to their arrest and are unable to take the pressures of a competitive production job. Straubing is therefore obliged to find less demanding work, with the usual drawback that most of it - domestic tasks or assembly work - is hardly likely to instil lasting work habits or teach useful skills. It is admittedly difficult to find viable alternatives since there are no budgetary provisions for protected industrial workshops that offer professional and social training.

One aspect that poses problems is the lack of options offered to the 230 inmates who are not working. One or two exercise periods per day and two additional hours out of the cell in the evenings are far from any rehabilitative ideal. Therapeutic facilities are limited, ${ }^{199}$ and daytime courses in education concentrate on basic skills that have little appeal for the majority of inmates. The productivity-oriented approach to work in Straubing, despite its undeniable advantages for inmates who already have some marketable skills, leaves too many of the more marginal prisoners out in the cold.

JVA Straubing is the only one of the nine research prisons that has been able to better its employment and training rate from an already respectable 67.8 per cent in 2002 to 69.5 per cent per cent in 2007 . This increase is mainly due to more workplaces in Prison Industries ( +44 jobs) that more than compensate the loss of 21 jobs in contract workshops and 16 in housekeeping. The population has stayed virtually constant at 874 inmates $(+0.01$ per cent). We will see in the next section that JVA Kaisheim has also been able to increase the number of jobs in its prison-run work-

199 AA groups, drug counselling, group sessions in social skills and anger management. Mandatory counselling for sex offenders was introduced in 2002. All sessions are usually scheduled after working hours. 
shops to compensate in some measure for the steep increase in its prison population. This is indicative of the economic viability of Bavarian Prison Industries and the determination of the Prison Service to maintain workshop employment despite the tougher market for outside contracts.

\section{JVA Kaisheim}

\section{General information about the prison}

JVA Kaisheim is housed in a former Cistercian monastery that dates back to the $12^{\text {th }}$ century, but was destroyed and almost entirely rebuilt in the early $18^{\text {th }}$ century. The monastery was secularised in 1803 and, a few years later, converted into a prison. A large part of the actual prison is still located in the old buildings. The walled in perimeter encloses an area of 5 ha. Outside the walls, the prison owns extensive farmland and woods, vegetable gardens, and a car repair shop. The small village of Kaisheim depends entirely on the prison. The next largest agglomeration is Donauwörth, a charming provincial town on the shores of the Danube that is better known for its tourist attractions than for its industrial vitality.

JVA Kaisheim is a prison for repeat offenders who have already served a previous prison term but do not pose an exceptional security risk. Sentences vary between one and six years. The prison was conceived for 476 inmates and provides 275 single accommodations and 201 places in dormitories that hold up to ten inmates. In 2002, the actual number of inmates was just over 600 . The staff numbers around 230, of which 30 are instructors in the different workshops. Compared to Straubing, the staff-inmate ratio is less favourable: roughly 1 to 3 instead of 1 to 2 . The shortage of staff is aggravated by the physical structure of the buildings, a patchwork of old and new - even if the old is very beautiful - that would require more staff than a custom built prison like Straubing. As a consequence, inmates are locked up early, ${ }^{200}$ and the time for common activities like sports or hobbies is severely restricted.

An open prison for 40 to 50 inmates in Ingolstadt, about $60 \mathrm{~km}$ downstream, is affiliated with Kaisheim. The same governor is responsible for both establishments, an arrangement that facilitates transfer from one establishment to the other.

\section{Work and Training}

In 2002, 310 to 330 inmates were working or in training. This corresponds to a paid activity rate of 51 to 55 per cent. Three years earlier, in January 1999, the employment picture was quite different. At that time, the total population did not ex-

${ }^{200}$ Lock-up time in most wings is 5 p.m. from Monday to Thursday and 3 p.m. on Friday, Saturday and Sunday. The 3 p.m. curfew also applies to holidays, even Christmas. 
ceed 476 inmates for whom 380 jobs were available. 80 per cent were thus either working or in training. The recent increase in the number of inmates could not be matched by a corresponding increase in work places, on the contrary: the introduction of labour saving machinery, a downturn in the economy and increased competition from Eastern Europe contributed to a net loss of almost seventy jobs.

Table 15: Paid activities at JVA Kaisheim

\begin{tabular}{|c|c|c|c|c|c|c|c|c|}
\hline Activities & $\begin{array}{l}\text { Prison } \\
\text { Industries }\end{array}$ & $\begin{array}{l}\text { Contract } \\
\text { workshops }\end{array}$ & $\begin{array}{l}\text { Farm/ } \\
\text { gardens }\end{array}$ & Domestic tasks & $\begin{array}{l}\text { Vocational } \\
\text { training }\end{array}$ & Education & $\begin{array}{l}\text { Therapeutic } \\
\text { workshop }\end{array}$ & Total \\
\hline $\begin{array}{l}\text { Number of } \\
\text { jobs }\end{array}$ & $140-160$ & $50-60$ & $15-20$ & 65 & 32 & (12) & 6 & $\begin{array}{l}326 \\
(338)\end{array}$ \\
\hline $\begin{array}{l}\text { Percentage } \\
\text { of paid } \\
\text { activities }\end{array}$ & $\begin{array}{l}46 \% \\
(44.4 \%)\end{array}$ & $\begin{array}{l}16.8 \% \\
(16.3 \%)\end{array}$ & $\begin{array}{l}5.5 \% \\
(5.3 \%)\end{array}$ & $\begin{array}{l}19.9 \% \\
(19.2 \%)\end{array}$ & $\begin{array}{l}9.8 \% \\
(9.4 \%)\end{array}$ & $(3.5 \%)$ & $\begin{array}{l}1.8 \% \\
(1.8 \%)\end{array}$ & $\begin{array}{l}100 \% \\
(99.8 \%)\end{array}$ \\
\hline $\begin{array}{l}\text { Percentage } \\
\text { of the total } \\
\text { population } \\
(604)\end{array}$ & $24.6 \%$ & $9 \%$ & $2.9 \%$ & $10.6 \%$ & $5.2 \%$ & $(2 \%)$ & $1 \%$ & $\begin{array}{l}54 \% \\
(56 \%)\end{array}$ \\
\hline
\end{tabular}

Figures in brackets include the remunerated educational activities

The salary structure is the same as in Straubing, and most work is paid at piece rates, but contrary to the practice in other establishments, capable inmates are allowed and even encouraged to exceed the required quota by more than 40 per cent. Good workers sometimes reach 200 per cent and are paid accordingly. The average weekly pay of our sample was slightly below Straubing (€66.1) at €62.2, but clearly above Schwalmstadt (€51).

Work allocation follows the procedure observed at the other two German prisons. Inmates hand in a written request to the workshop manager (Werkdienstleiter) for an industrial job, which includes also work in the kitchen, bakery, laundry and gardens. Maintenance and cleaning jobs are allocated by wing directors in consultation with other wing staff. The workshop manager can decide alone on industrial placements, and there are no binding guidelines. In practice, any good manager discusses new allocations with his staff and takes into account informal requests from psychologists or social workers. The regular weekly wing meetings as well as discussions over shared lunch in the mess lend themselves to this kind of informal exchange.

Health and safety standards are well enforced. As at JVA Straubing, a special officer is appointed to handle these issues. The legal provisions are strict: the Trade 
Inspection Board and the Work Accident Insurance Board have the right to send unannounced inspectors at any time in addition to the mandatory yearly inspection. The governor too can call in inspectors if, for instance, he is not satisfied by the measures taken by outside contractors. In case of a work accident, the Accident Insurance Fund will pay the inmate $80 \%$ of his salary while he is unable to work.

\section{a) Productive Work}

69 per cent of all jobs (210 out of 320) fall in this category. The prison has 13 Prison Industry workshops ${ }^{201}$ and four workshops run by private enterprise. The bulk of work is thus provided by prison run industries. Prisoners work, like in the rest of Germany, 38.5 hours per week: Monday to Thursday from 7 a.m. to 11. a.m. and from 12.45 a.m. to 4 p.m., and on Fridays from 7 a.m. to 12.30 p.m. Since the introduction of higher wages, inmates have to clock in as they would in a factory on the outside.

The annual budget for Prison Industries varies between $€ 100,000$ and $€ 115,000$. The financial manager can invest part of this amount in new equipment, up to $€ 5000$ per piece, without a special application to the Ministry of Justice. Larger investments have to be approved both by the Ministry of Justice and the Ministry of Finance.

The financial manager is responsible for contracts with outside firms. He aims at a profit of a minimum of 50 cents and up to $€ 4$ per prisoner and per working hour, averaging about $€ 2$. This should cover costs (salaries of the inmates, employer contribution to unemployment insurance, electricity, heating and supervision) and leave a small profit. For the financial manager, making a profit is essential if prison labour is to be taken seriously. The more financially successful a workshop, the better the inmates will work. The better they work, the more interesting the orders received.

Prison Industry workshops in Kaisheim are a good example of how a dedicated workshop manager and his team of instructors can adapt to the challenges of a globalised economy and a changing prison population. I will examine two groups of workshops.

Textiles are the biggest sector and comprise three workshops that produce most of the textiles, clothing and footwear for Bavarian prisoners. In the weaving (mechanical looms) workshop, the fabrics for all prison clothing are woven, and 9 inmates, 2 apprentices and 2 manual weavers work under the guidance of two master instructors. Kaisheim is the only prison in Germany to offer a two-year apprenticeship in mechanical loom programming and maintenance, and a three-year apprenticeship in loom mechanics. Working conditions are difficult as the noise level is extremely high, but inmates are given a bonus in compensation. The trainees, who

201 This number does not include kitchen, bakery, laundry, farms and gardens. 
get through the apprenticeship, are said to have very good chances on the job market after release, as there is a shortage of skilled operators and mechanics in this field. A former inmate, for instance, is now the manager of a textile plant in Austria.

The tailoring workshop employs 35 machinists, 3 cutters and one apprentice. It makes the prison garments for the whole of Bavaria that is for about 12,000 inmates: underwear, work pants, shirts, jackets, parkas, handkerchiefs, towels and face towels. Small orders for members of staff will also be accepted, and occasionally a bigger contract for traditional costumes. These orders are mainly executed by the two instructors, as most inmates have never touched a sewing machine before and do not have the necessary skills for more complex tasks. When inmates are assigned to the workshop, they are given an initial training period, during which they are paid at a fixed hourly rate. Once they have reached a reasonable pace, they are paid piece rates. The head of the workshop has no illusions about the productivity of his workshop, acknowledging that it can never be equal to the output outside for several reasons: the machines do not perform as well, the prison routine with its security checks and locking up periods wastes precious working time, inmates come with no previous training, turnover is high and enthusiasm for the job often low. Despite these handicaps, the quality of the products is good.

The shoe factory employs 25 inmates plus 2 trainees and produces all the shoes handed out to Bavaria's inmates. In 2001, the workshop produced 20,000 pairs of shoes for inmates and 15,000 to 20,000 for outside sale. The term "shoe" refers here to models for inside use only, that is various kinds of slippers and house shoes. Quality requirements are high, as the same models are sold on the outside market. Each worker produces the whole shoe, not just a part. This involves about thirty different operations and makes the work more varied.

The printing shop is one of the smaller workshops ( 5 print setters and printers, 2 computer designers and 3 apprentices), but it is remarkable for the quality of its work (forms for prison establishments and the justice department, publicity folders for industry and political parties) that is done with relatively unsophisticated machines. There is an excellent team spirit, and dull jobs like folding and packing are done as a group. Even difficult inmates that create problems on the wings settle down, and the success rate of the apprentices and the job satisfaction of the workers are exceptionally high. Much of this success is to be attributed to the professional and personal qualities of the two master-instructors. Noteworthy also is the strong drive to find external clients and to offer specialized and custom made work, for instance bound leather photo albums that are produced by the small bookbinding department.

Contract work occupies relatively few inmates: 50 to 55 . The reasons given are the lack of floor space to make room for new workshops, ${ }^{202}$ and fierce competition

202 Three of the four workshops take up the space of the former hall, where working inmates used to eat their lunch in common, before new regulations made lock-up in the cells during lunchtime mandatory. 
for a small number of contracts in a less industrialised region of Germany. The only big industry, a helicopter plant, refuses to deal with prisons for fear that this could create an image problem.

One company outsources the assembly of plastic toy trucks. The workshop turns out about 40,000 of them per year. As the company uses other prisons, it plays one against the other. The profit margin is therefore minimal (35 cents per worker per hour, not enough to cover the cost), but any request for better pay is met with the threat to move the production to an Eastern European country.

Another firm is financially more interesting for the prison, but less popular with inmates. Here, the contractor uses the prison for a variety of tasks (sorting, folding and packing jobs), which means that inmates have to adapt frequently to new production lines. This slows them down and reduces their bonus. On the whole, the rehabilitative value of both workshops is minimal and they serve essentially to keep inmates busy and let them earn some money.

\section{b) Domestic and maintenance work}

The most important production units that take care of the daily needs of the prison population are the kitchen (14-15 inmates), the bakery (5 inmates), the laundry (14 inmates), the farms (7-8 inmates) and the gardens (14 inmates). The kitchen has to face up to a considerable challenge. Conceived for a population of 450 inmates, it now has to cope with over 600 . The equipment is dated, the budget minimal ( $€ 2.11$ per prisoner per day), and several diets have to be offered to meet the demands of Muslims, vegetarians, vegans, diabetics, those who need a low fat diet, or those who have to put on weight. There are plans for a new building that would house a modern kitchen, a butcher department, the bakery and a bigger laundry, which is also stretched to the limits by the increase of the prison population. Lack of funding has put these plans on hold for the next few years.

About 50 inmates are given cleaning jobs. The equipment, especially for the old parts of the abbey with its marble floors and spacious corridors, is fully mechanized and gives the inmates same training in industrial cleaning. The equipment for the wings does not quite match these standards.

\section{c) Therapeutic workshop}

Kaisheim has a small therapeutic workshop for 6 to 7 inmates that specialize in a whole range of crafts. The need for this kind of workshop is considerable for inmates with drug and alcohol related problems or other social casualties who cannot take the pressure of a regular workshop. They greatly benefit from structured sessions that let them use their hands and their imagination, get them out of the isolation of their cells and give them a feeling of achievement. Ideally, the size of the workshop should at least be tripled. 
d) Vocational training

Two-year apprenticeships are offered in most workshops. Although 54 places are available in 15 professions, most apprenticeships are concentrated in two fields: electronics and engineering. Both shops offer the choice between a two-year training course and shorter, modular courses (introduction to electronics I and II, welding, and introduction to mechanics). In the other workshops only a two-year apprenticeship is offered. Modular courses are best adapted for medium term prisons like Kaisheim for it is often difficult to fit in a two-year course at the right period of the sentence. Cooks, for instance, have to work three months in an à la carte restaurant before they can sit the exam. This means that for three months they need a permit to leave the prison until late at night - permits which judges are reluctant to grant except at the very end of the sentence. The same applies to car mechanics. They can do the first year of training inside but in the second year, practical experience in the prison car repair shop becomes indispensable. As judges become increasingly restrictive in granting outside work permits, these two apprenticeships risk being phased out, even if they offer excellent job opportunities upon release.

The official funding body (Arbeitsamt) only funds training for people who have worked at least 360 days within the last three years, and this condition is not easily met by many inmates. Furthermore, the end of training has to be close enough to the release date in order for the trainee to take up work in his field within six months. As the prison has no control over the release date, the number of rejected applications for training is exceptionally high.

\section{Comments}

Thanks to a dedicated team of work administrators and instructors, Kaisheim runs a number of excellent workshops with a variety of semi-skilled and skilled tasks. The income generated in 2001 through various contracts amounted to $€ 1,296,529$ and is more than respectable given the unfavourable location and the difficult mix of inmates. These positive aspects are no excuse, however, for the high unemployment rate and the lack of alternatives for the unemployed. The situation is even worse than in Straubing. It is often said that prisoners are lazy, but this is not the impression I got walking down the corridors with the workshop manager. He was constantly assailed by inmates asking for work. Finding extra work for 200 inmates $^{203}$ is no mean feat, however. New guidelines after the wage increase for prisoners on 1 January 2001 have made job creation even more difficult since job sharing is discouraged because the unemployment contribution paid by the Prison Service (€6.34 per day) is the same if a prisoner works 1 hour or a full day. It is therefore economically more advantageous to have a smaller workforce working

203 Of the 266 inmates without a paid activity some were excused for health reasons, but the vast majority wanted to work. 
full-time. This leaves the unemployed in a pathetic position without income and with nothing to do. They are even excluded from the most popular sports such as soccer and weights as insurance only covers those who are working.

When asked to explain the acute shortage of jobs, the head of industries and the instructors underlined four factors that are symptomatic of the problems encountered in most of the nine prisons.

1) Workshops suffer from the location of the prison in a remote, lightly industrialised area of Bavaria.

2) There is fierce competition for contracts from the four other prisons in the area and from the centres for the handicapped.

3) Kaisheim cannot compete with outside industry in terms of equipment, and there is no room to install whole production lines that would allow serial production of constant quality.

4) The quality of the workers, according to the instructors, is in constant decline. Most inmates left school without a school leaving certificate and have had, at best, sporadic work experience. This assessment has been confirmed by the teaching staff and is particularly true for a prison like Kaisheim with a population of smalltime repeat offenders. Given these constraints, the quality achieved in the workshops and the generally high worker satisfaction are all the more impressive.

The latest statistics (June 2007) present a mixed picture. The rise in the number of inmates, from 604 in 2002 to 735 in 2007 ( +21.7 per cent), could only be matched in part by a corresponding increase in workplaces. Although Prison Industries now offers 38 additional jobs and attendance in the therapeutic workshop has gone up from 6 to 15 inmates, employment provided through outside contracts and in the domestic sector has remained unchanged, and vocational training shows a small decline (from 32 trainees in 2002 to 23 in 2007). The work and training rate has thus decreased from 54 per cent in 2002 to 50.1 per cent ( 368 places for 735 inmates). Given that there are only 12 full-time students, the number of inmates left without an occupation remains very high.

\section{English Prisons}

English prisons will be examined in the following order: Her Majesty's Prison (HMP) Frankland, HMP Featherstone, and HMP Swaleside.

\section{A. HMP Frankland}

\section{General information about the prison}

HMP Frankland is one of six high security (dispersal) prisons in England and Wales and has a mixture of category A and B prisoners. It is situated in the rural North of England, on the outskirts of the cathedral town of Durham. It was the first 
dispersal prison to be built and opened in 1983. In the 1990s, two wings, including a small drug recovery unit, were added to the original four sections. Frankland has been chosen as one of four test sites for the treatment of inmates with serious personality disorders. This unit opened in 2006 and can accommodate 80 inmates. Their therapeutic workshops focus on arts and crafts and do not enter into our study.

The psychiatric unit apart, the prison has an operational capacity of 653 . Two wings are reserved for 120 offenders on normal location, that is, prisoners that do not require special protection, and four wings for 550 vulnerable prisoners, mainly sex offenders. The number of prisoners serving a life sentence is increasing, and there is a small but growing proportion of elderly prisoners. The average sentence length is 15 years.

\section{Work and Training}

Although work in an English high security prison is not fundamentally different from prison labour in other European prison, it has distinct features worth pointing out. There is, for one, the strict separation of regular and vulnerable inmates. They share the same workshop area but never meet. Another feature is the short workday. Inmates work only 4 1/4 hours, from 8.30 a.m. to 10.45 a.m. and from 13.45 p.m. to 15.45 p.m. This is for two reasons: regulations for dispersal prisons prescribe one exercise period per day, from 10.45 a.m. to 11.40 a.m., even for inmates at work. This may have been appropriate at a time when prisoners worked mainly in their cells, but it has now become an anachronism, especially since inmates can use the gym after work and on weekends. The generalized practice of early lunch, at 11.40 a.m. followed by lock-up till 13.45 a.m. while prison officers have their midday break, further hinders the extension of the workday. This practice has been criticized by at least two Chief Inspectors of prisons as well as by the Woolf Report, but negotiations with the Prison Officers' Union have thus far shown little progress. Given the short working hours, the income generated by the workshops is considerable. In 2001, Prison Industries produced goods worth $€ 1,976,000$ (1.3 million pounds), and the woodwork shops alone made a profit of about $€ 760,000$ (500,000 pounds).

In 2002, 402 inmates were active in workshops, service jobs or full-time professional training. This means that 59.8 per cent of the total population (672) were actively employed. If we include full-time education (counted as a paid activity in England), the activity rate reaches 78.7 per cent. ${ }^{204}$ Of the 126 inmates without an occupation, about 33 were actively looking for work. Of the others, some were no

204 This percentage does not take into account physical education and accredited programmes addressing offending behaviour. 
longer required to work or had stopped applying because they could not cope with a regular job. There are few provisions in England, as elsewhere, for inmates with psychological problems who would need some form of sheltered work.

Table 16: Remunerated activities at HMP Frankland

\begin{tabular}{|c|c|c|c|c|c|c|c|c|c|}
\hline Activity & $\begin{array}{l}\text { Wood- } \\
\text { mill }\end{array}$ & $\begin{array}{l}\text { Uphol- } \\
\text { stery }\end{array}$ & Assembly & $\begin{array}{l}\text { Charity } \\
\text { work }\end{array}$ & Braille & $\begin{array}{l}\text { Domestic } \\
\text { tasks }\end{array}$ & $\begin{array}{l}\text { Vocatio- } \\
\text { nal Trai- } \\
\text { ning }\end{array}$ & Education & Total \\
\hline $\begin{array}{l}\text { Number } \\
\text { of inma- } \\
\text { tes }\end{array}$ & 92 & 40 & 24 & $32+10$ & $14+4$ & 150 & 36 & $(127)^{205}$ & $\begin{array}{l}402 \\
(529)\end{array}$ \\
\hline $\begin{array}{l}\% \text { of all } \\
\text { rem. act. }\end{array}$ & $\begin{array}{l}22.8 \% \\
(17.4 \%)\end{array}$ & $\begin{array}{l}9.95 \% \\
(7.6 \%)\end{array}$ & $\begin{array}{l}5.97 \% \\
(4.5 \%)\end{array}$ & $\begin{array}{l}10.4 \% \\
(7.9 \%)\end{array}$ & $\begin{array}{l}4.47 \% \\
(3.4 \%)\end{array}$ & $\begin{array}{l}37.3 \% \\
(28.4 \%)\end{array}$ & $\begin{array}{l}9 \% \\
(6.8 \%)\end{array}$ & $(24 \%)$ & $100 \%$ \\
\hline $\begin{array}{l}\% \text { of } \\
\text { total } \\
\text { pop. } \\
(672)\end{array}$ & $13.7 \%$ & $5.9 \%$ & $3.6 \%$ & $6.2 \%$ & $2.7 \%$ & $22.3 \%$ & $5.4 \%$ & (18.9) & $\begin{array}{l}59.8 \% \\
(78.7 \%)\end{array}$ \\
\hline
\end{tabular}

Figures in brackets include the remunerated educational activities.

The pay scale was undergoing a review in 2001 with planned increases across the board of a minimum of 5 per cent.

1) Pay rates for workshops are split into three grades, depending on the responsibility of the job and inmate status.

- Top wages (€30/£20 per week) are paid to one or two prisoners in each workshop responsible for quality control. These prisoners ensure that all the procedures are carried out to the requirements of ISO 9002.

- Prisoners with enhanced status ${ }^{206}$ can earn up to $€ 28.50$ (£19).

205 The charity workshop is funded by education and figures therefore in the official statistics as an educational activity, which brings up the numbers in education to 168 .

206 English prison regimes are based on three privilege levels: basic, standard and enhanced.

Basic is the lowest level. Usually inmates get demoted to basic for behavioural reasons. Basic prisoners have to wear prison clothes, have minimum visiting time and can only receive $€ 7.50$ (£5) per week of outside cash. They also only have one gym period per week. 
- Standard prisoners receive a maximum of $€ 27$ (£18).

2) Pay rates for inmates working in the service sector vary greatly, depending on the skills required and the hours worked. Cleaners earn between $€ 17$ and $€ 24$ (£11.20 to £16), laundry workers and library orderlies can go up to $€ 30$ (£20), whereas cooks, because of the long and awkward hours, are paid $€ 37.50$ to $€ 39$ ( 25 to £26).

3) Inmates in full-time professional training start at $€ 18$ (£12) and are paid $€ 20.25$ (£13.50) after half term.

4) Unemployed, retired or sick inmates receive the following weekly payments:

$\begin{array}{lll}\text { Unemployed: } & € 4.50 & (£ 3) \\ \text { Retired: } & € 15 & (£ 10) \\ \text { Sick: } & € 4.50 & (£ 3) \\ \text { Self-declared sick: } 207 & 90 \varnothing & (60 p) \text { per day }\end{array}$

Even inmates that have been dismissed or are placed in the segregation unit receive $€ 4.50$ a week.

5) Workers who are temporarily laid off because of lack of work continue to receive their wages.

Labour allocation procedures are more formal in a dispersal prison. Three criteria have to be met before a job can be assigned: security clearance for the particular post, physically fitness, and work that fits in with the sentence plan. All written applications are thus first sent out to security, to the hospital section and to sentence planning. The labour board meets once a week and is composed of the industrial manager (chair), the assistant industrial manager, a security representative and an education representative. The application may also be discussed with the personal officer who knows the inmate best. The final decision lies with the chair. The board tries to take into account the needs and requirements of both prison and prisoner. It ideally assigns each inmate to a job that allows him to improve his educational and

Standard is the normal entry level regime. Prisoners can wear their own clothes (most choose not to do so), they are allowed in-cell TV, are granted better visiting rights, can receive $€ 15$ (£10) of outside cash a week and may use the gym during six periods.

Enhanced level has to be earned by good behaviour (no adjudications, no positive drug testing, good work record or participation in other programmes). On this level, inmates can wear their own clothes, have visiting privileges, can receive $€ 22.50$ (£15) of outside cash, have eight gym periods per week and, in addition, better accommodation (Sky TV, kitchen facilities, better snooker tables).

207 Each working inmate has the right to book in sick without seeing a doctor for a maximum of five days per year. He can thus avoid disciplinary measures if, for reasons that do not warrant a medical certificate, he occasionally is not up to going to work. 
vocational skills but the deciding factor is always the risk an applicant could pose in the workshop. The results of the board meeting are communicated to all the departments; the prisoner receives a written reply and, in case of a negative decision, an explanation why his application was turned down. The process of assigning jobs for wing cleaners and orderlies is less formal. Wing officers, after consultation with security, can choose their own candidates.

The procedures for dismissal have been clearly spelt out in writing by the current head of industries. There are only two grounds for dismissal: inefficiency and unacceptable behaviour at work. In the case of inefficiency, the work instructor must submit his reasons in writing to the labour board and demonstrate that all steps were taken to bring the inmate up to standard. The measure taken in the case of unacceptable behaviour depends on the gravity of the offence. In the most serious cases, the prisoner is dismissed immediately and is put on report. This means that he will have to go through a disciplinary hearing with the governor (adjudication) and will not only lose his job but be given some other sanction as well. Instructors prefer therefore, when ever possible, the milder method of "three strikes". If a prisoner does not work well on purpose, a warning is issued. If this does not produce the desired results, the prisoner faces a pay reduction. Only if this second step fails is a request for dismissal sent to the labour board but without putting the inmate on report. Decisions of dismissals must be confirmed by the governor, and the prisoner concerned has the right to appeal the decision to the Head of Regimes.

In his 2001 report, ${ }^{208}$ the Chief Inspectors of Prisons commented favourably on the great progress made concerning health and safety standards. A risk assessment for all work areas had been put in place, and staff have been trained to spot risk areas.

\section{a) Productive work}

In 2002, roughly 180 inmates worked in industries or had signed up for vocational training courses -237 if we add the 40 inmates from the charity shop and 17 from Braille who, for budgetary reasons, figure under education. The bulk of jobs are provided by Prison Industries, as Frankland operates only one contract workshop, reserved for inmates on normal location.

Furniture manufacture (woodwork) is the main prison-run industry and employs about 132 inmates (vulnerable units). The goods produced are worth about 1.3 million pounds, and the profit is estimated at 500,000 pounds. All workshops are ISO 9002 certified. The production is divided among three workshops: the wood mill, the assembly shop, and the paint shop. All instructors are qualified at a level com-

208 HM Chief Inspector of Prisons (2001). 
parable to the German Meister, and take considerable pride in the fact that their workshop received ISO 9002 certification the first time round. As their competence is obvious to all, there is no need to make a show of it. Everybody is on a first name basis, even nicknames are used. Whenever possible, inmates are included in the planning of the work process and can make suggestions for the design of the furniture. There is little turnover, as most inmates tend to stay for long periods.

A complementary upholstery unit has 15 inmates working on leather upholstery (chesterfields, sofas for government offices or private customers) and 30 others as cutters and machinists. Leather upholstery is a good example of prison work at its best because the task requires skill, patience and the ability to work without supervision. Worker satisfaction is accordingly high. ${ }^{209}$ The workshop is also financially interesting for the prison as the products have a high added value: a chesterfield and two easy chairs are said to sell on the outside market for a minimum of $€ 1500$ (£1000). Training is on the job and takes about six to seven weeks for motivated inmates. In 2002, NVQs in leather upholstery were still in the planning stage but are now in place.

The only contract workshop in Frankland is also the only one that caters to prisoners on normal location. The contractor is a US company specialized in prison labour, in this case the assembly of office furniture. The firm provides the design and the component parts, which are then assembled and shipped from prison. In 2002, the workshop had just opened and the business volume was still small $(€ 450,000 / £ 300,000)$, barely enough to employ 29 inmates. Ideally, the volume will be boosted to $€ 1,500,000$ ( $£ 1,000,000)$ in order to make the production commercially viable and increase the number of jobs. Part of the production would then go to other prisons, but Frankland would remain the centre. Work, in the future, will also be combined with training in computer-assisted design (CAD), which will enable inmates to design office furniture for individual customers rather than have to wait for the U.S. head office to send the plans.

England is the only country to have "humanitarian" workshops entirely financed by educational institutions or trusts. The advantages of such ventures are considerable. Jobs are created at no extra cost, providing inmates with useful, "honourable" and comparatively well paid work. During interviews, several inmates made a point of saying that this kind of charity work allowed them, in a small way, to pay back their debt to society.

209 One inmate, who was awarded the prestigious Koestler Award for his exceptional upholstery work, told us that this is the first job in his career that is interesting and that has taught him a useful skill. He knows what he is talking about, as he is a lifer with a tariff of 25 years and has been to several other dispersal prisons before coming to Frankland. To him, this workshop is unlike any other he has worked in: the staff are willing to experiment and to try something new. At the same time they insist on the highest quality standards and would rather dismantle a finished sofa than tolerate imperfections. It is this combination of perfectionism and innovation that he finds most stimulating. If he could, he would gladly work longer hours. 
Frankland has two workshops of this kind. In the so-called Charity Workshop three instructors train 32 vulnerable inmates and 10 part-time induction inmates to repair old bicycles, sewing machines, typewriters and wheelchairs for use in third world countries. The project is financed through the education budget in collaboration with the Inside Out Trust. It is aimed at inmates who need to improve their educational qualification as it allows them to spend two half-days a week in the education department working on basic or key skills. The courses are closely tied in with the actual work experience, and math exercises may, for example, include measuring wheelchairs. Pay rates are high $(€ 27.40 / £ 18.00)$ in order to attract inmates who would not normally consider taking classes.

In the second workshop, 14 inmates learn to transcribe textbooks into Braille for the blind. The studio is financed by the Royal National Institute for the Blind, and the contracts are provided through the Inside Out Trust. It is run by a prison officer with the help of a " $n^{\circ} 1$ " prisoner who is an expert braillist and does most of the training. One cannot help but be impressed to see inmates transcribe university level science textbooks, complete with charts and diagrams. The pay rates are low compared to the Charity shop, considering the highly skilled nature of the work. Beginners start at $€ 15.30$ ( $£ 10.20$ ), and the maximum pay is in the range of $€ 23.25$ (£15.50). Apart from some complaints about the level of remuneration, worker satisfaction is high, as their job is challenging and socially useful. Whether inmates can find work in this field later on is another matter.

\section{b) Domestic tasks}

Cleaners, orderlies, maintenance workers and cooks ${ }^{210}$ make up a rather large percentage of the workforce (37.3 per cent or 150 out of 402). This figure is considerably higher than at HMP Featherstone (26.9 per cent) or in French and German prisons. Only HMP Swaleside employs more inmates in this capacity (45.7 per cent). The reasons for this high rate are twofold: the relative shortage of industrial jobs and the necessity in high security prisons to keep inmates occupied, even in jobs that teach them little in the way of skills and do not prepare them for future employment. But not all domestic jobs are without prospects. The 16 assistant cooks, for instance, have the opportunity to work toward their national vocational qualifications (NVQs) in institutional cooking. It takes them on average two years to complete level one and two. They learn to provide different diets provided in hospitals or other big institutions (regular, vegetarian, vegan, Muslim, kosher, diabetic and low fat), and this on a small budget ( $€ 2.34 / £ 1.56$ per person per day).

21072 cleaners, 12 laundry orderlies, 8 servers, 1 store orderly, 7 gym orderlies, 8 education orderlies, 2 hospital orderlies, 1 hospital gardener, 14 wing painters, 7 farms and gardens, 16 kitchen staff. 
c) Vocational training

Vocational training in the conventional sense is reserved for prisoners on regular location. Two courses are offered, one in bricklaying for 9 to 11 students, and a second one in furniture craft for 12 inmates. The courses are structured in such a way that new students can join the class at any time. Each trainee works at his own speed. Some manage to finish the course in 12 weeks, others take 12 months. Students must not only show that they can build walls or make furniture, they also have to pass tests in literacy, numeracy and communication. Both vocational training courses lead to City \& Guild qualification. Unfortunately, students are no longer awarded the more prestigious NVQs in bricklaying because they cannot comply with the recently added requirement of scaffolding. They are also not allowed to take part in the national inter-prison bricklaying competition in which category $\mathrm{B}, \mathrm{C}$ and $\mathrm{D}$ prisons compete against each other and against technical colleges. So far no technical college ever won!

A third course is offered by the education section for vulnerable prisoners in Art and Design. One might hesitate to classify it under vocational training, as it combines vocational, artistic, therapeutic and educational elements. It is designed as an A-level course and is taught on two levels: a theoretical level (art history, design, various techniques) and, as students advance, increasingly on an applied level (drawings, etchings, different types of paintings: water colours, gouache, oils). The 17 students stay in the studio as long as they are still learning, up to a period of four years. What makes this course unique is that it caters to the most difficult prisoners and that the teacher - a slight, middle-aged woman - has created a working climate in which inmates considered unmanageable and dangerous calm down and blossom. Some of their artwork is of very high quality. Students are paid between $€ 15.90$ and $€ 18.30$ (£10.60/£12.20) a week and are allowed to sell their paintings. The teacher takes no credit for the achievements of her students and attributes their progress to the medium of art that enabled them to express their frustrations, suffering and guilt in a positive way. Some may consider this project an unnecessary luxury, but having seen the inmates at work and having been told something about their background, I cannot but be amazed at the transformations achieved in this studio. This explains why the governor, despite severe budget cuts, is determined to maintain it.

\section{Comments}

HMP Frankland has much to be proud of. In her Annual Report, ${ }^{211}$ the Chief Inspector of Prisons ranks Frankland in the highest category for safety and respect, and in the second highest ("performing reasonably well") for purposeful activity.

${ }^{211}$ HM Chief Inspector of Prisons (2007), p. 80 
The only negative evaluation concerns resettlement, which is a difficult area to handle for a dispersal prison. In a slightly older report (2001) ${ }^{212}$ the Chief Inspector praised the prison as "well managed", providing a "constructive environment", where a difficult population is "healthily held". The workshops play a major part in this positive assessment, many of them providing semi-skilled or skilled work. The guidelines for hiring and dismissal are among the best I have seen in any of the three countries. Frankland favours a holistic approach to regimes and insists that the different regime activities (work, training, basic and physical education, offending behaviour courses) not be treated as separate entities in competition with each other, but as part of an integrated programme for each inmate. Instances of this approach can be seen in the Charity shop, were two half days are set apart for education. Another successful experiment is the integration of key skills with the gymnasium that offers several certificates, all centred on sport.

The governor commented that the varied regime at Frankland produced happier inmates with fewer control problems. He would even go as far as replacing fulltime education by part-time courses combined with work or accredited offending behaviour courses. His interest in the workshops has certainly played an important role in the good performance of the productive sector. If the efforts of his staff to increase the volume of work and the number of jobs have not been as successful as hoped for, this has partly to do with Enterprise and Supply Services (ESS) not finding enough customers for prison made goods and businesses willing to give prison a try. Even if the industrial manager tries to get local contracts, he is greatly handicapped by the location of the prison in a rural zone with high unemployment. Frankland is further disadvantaged by not qualifying for EU resettlement grants, as dispersal prisons cannot release prisoners directly. For the same reason it is also excluded from a parallel British scheme, Custody to Work, which teams up prisons with major industries like British Gas that take on a certain number of trained inmates when they are released.

At the present time, virtually all tasks are of the blue-collar type. Given that the vast majority of inmates are vulnerable prisoners, a category that often has a better educational background than regular inmates, it would be worth following the recommendations of the Workshop Expansion Scheme 213 to try to attract contracts from service sector industries such as desktop publishing, record conversion, telecentres, etc. Such jobs could be combined with training in small business management, an option strongly favoured by the industrial manager since running their own business may be the only option open to inmates whose chances on the job market are strongly compromised by their criminal record.

\footnotetext{
212 HM Chief Inspector of Prisons (2002), p.1.

213 Fulton (1996), Workshop Expansion, p. 43-44.
} 
The latest statistics (June 2007) are the following: the number of prisoners has risen to 730, of whom 195 work in Prison Industries, 57 in the Charity workshop, and 15 in Braille. The computer furniture manufacture has been closed and has not been replaced by other contract work. 130 inmates are employed in a domestic capacity, 22 are in full-time training, and 78 in full-time education. The professional activity rate (work and professional training) is thus slightly lower than in 2002: down from 59.4 per cent to 54.4 per cent. If we include full-time education, the paid activity rate is 65.1 per cent. Five years earlier, it was 78.3 per cent.

\section{B. HMP Featherstone}

\section{General information about the prison}

Featherstone is a modern, purpose built category $\mathrm{C}$ prison situated on a former military base some twelve kilometres north of Wolverhampton, a busy industrial town in the Midlands. Despite its vicinity to an urban centre, the location is quite isolated and far from public transport. The prison opened in 1976, originally with four living units. The fifth, added in 1992, raised the population to 599. The bulk of the inmates come from the surrounding area and serve sentences from life to a matter of months. The turnover rate is correspondingly high: 40 per cent spend only between nine and fifteen months at the prison. ${ }^{214}$

Featherstone is of particular interest as it is one of the two English industrial prisons. ${ }^{215}$ The term "industrial prison" implies, in the first place, that Prison Industries are run on proper commercial lines and that inmates are exposed to the same working environment they will meet when applying for a factory job outside. Second it means that work is given a central status among regimes activities, and the majority of prisoners are occupied in industrial work. The concept of industrial prisons dates from the 1960, a time of economic boom, when industrial jobs were plentiful and it was reasonable to assume that properly trained inmates could find work in a factory on release. It was also believed that a stronger business orientation would make workshops more profitable. Neither Featherstone nor Coldingley have been able to fully live up to such expectations. ${ }^{216}$ It is not easy to operate workshops on normalised lines when other regime activities like education have to be accommodated, and major obstacles still stand in the way of productivity (security consideration, staff inflexibility, high turnover, low motivation, etc.). In order

\footnotetext{
214 Leech (2006), Prisons Handbook, p. 132.

215 The other, slightly older prison is HMP Coldingley, which opened in 1969 and features modern manufacturing workshops in paint-dipping, engineering, laundry services and sign-making.

216 Vagg/Smartt (1999) in: van Zyl Smit/Dünkel, p.53.
} 
to give Prison Industries a boost, in 1997 Featherstone became part of a pilot project know as Workshop Expansion Scheme. The targets were ambitious:

$100 \%$ workshop occupancy, which means that enough work had to be provided to fill all available workplaces.

$60 \%$ workshop productivity, measured against outside factories.

35 working hours per inmate per week (by 2000).

The initial success was impressive. The longer workshop hours were popular with inmates as it gave them more time out of the cells and allowed them to earn higher wages. Productivity and output went up, and new workplaces were created. But the rate of expansion could not be maintained after the first year because funding fell short of the needs for modernization and up-to-date equipment.

\section{Work and Training}

Industrial work at Featherstone is heavily concentrated in two areas: textiles and engineering. Additional workplaces are provided by the allocation shop, the dairy farm, and a small horticultural unit. 85 inmates are employed in a domestic capacity, 18 to 20 are in full-time professional training, and 54 are in education. This gives an employment rate of 66 per cent (395 of 599) or of 75 per cent (449 of 599) if we include the full-time students.

Table 17: Remunerated activities at HMP Featherstone

\begin{tabular}{|l|l|l|l|l|l|l|l|l|l|}
\hline Activities & $\begin{array}{l}\text { Enginee- } \\
\text { ring }\end{array}$ & Textiles & Allocation & $\begin{array}{l}\text { Domestic } \\
\text { tasks }\end{array}$ & Other & $\begin{array}{l}\text { Agriculture } \\
\text { and Horticultu- } \\
\text { re. }\end{array}$ & $\begin{array}{l}\text { Vocational } \\
\text { training }\end{array}$ & (Ed.) & Total \\
\hline $\begin{array}{l}\text { Number of } \\
\text { jobs }\end{array}$ & 120 & 120 & 30 & 85 & 10 & $8+4$ & 18 & & 395 \\
\hline $\begin{array}{l}\% \text { of all } \\
\text { paid acti- } \\
\text { vities }\end{array}$ & $\begin{array}{l}30.4 \% \\
(26.7 \%)\end{array}$ & $30.4 \%$ & $7.6 \%$ & $21.5 \%$ & $2.5 \%$ & $3 \%$ & $4.6 \%$ & $(54)$ & $(449)$ \\
\hline $\begin{array}{l}\text { \% of total } \\
\text { population }\end{array}$ \\
$\begin{array}{l}(599) \\
\text { (59) }\end{array}$
\end{tabular}

Figures in brackets include the remunerated educational activities.

Pay-rates vary between $€ 6.00$ ( $£ 4.00$ ) for part-time cleaners and $€ 30.00$ (£20.00) for dairy farm workers and textile workers that are paid piece rates. The average 
pay for our sample was $€ 19.15$ (£12.75). To achieve a 35-hour working week, workshops would have to run from 7.55 a.m. to 12.10 a.m. and from 13.35 p.m. to 16.50 p.m. Monday to Thursday, and from 7.55 a.m. to 12.00 a.m. on Friday. This aim has not yet been reached, and workshops operate 27 hours on average.

Allocation procedures resemble the ones described for Frankland. Inmates make a written application to the labour allocation board (composed of the industrial manager, the workshop manager and the allocation officer) stating their preferences. If possible, they are placed in the workshop or sector of their choice but, given the tight job market, most settle for whatever opening is proposed to them. The criteria for dismissal are not as clearly spelt out as at Frankland but are based on the same principle of "three strikes". On the third warning, the prisoner finds himself demoted to basic regime for 28 days, during which he is not allowed to work.

\section{a) Productive work}

Production is divided into two sections: industry and dairy farming. The once thriving dairy production has dwindled to insignificance, at least as far as the number of jobs (8) is concerned, but industrial production is thriving. The two main workshops, engineering and textiles, are each headed by a production manager and a workshop manager and employ between 220 and 240 inmates. In contrast to other prisons, Featherstone has no proper contract workshops. Both textiles and engineering take on some contract work, but their production is still mainly geared towards the internal market.

The engineering shop employs between 110 and 120 inmates, supervised by 17 instructors. The production is primarily focused on the internal market: cell doors, metallic bed frames, metal tubes for chairs, fencings, etc., but external sales are increasing. These are usually specialized contracts, such as the production of shovels for the handicapped or the assembly of bodywork for heavy machinery. Occasionally, they include contracts for community projects: in 2000, inmates in engineering made 87 steel gates for a low-income housing estate near Newcastle in order to cut off the shared alleyways from unwelcome intruders. The gates were then installed by offenders sentenced to community work. This was praised as an excellent example of restorative justice.

The work is varied, ranging from simple sawing and bending to operating computer-controlled machines. Attached to the engineering workshop proper are to smaller units: a paint and spray shop, and an assembly unit. Training is an important factor in engineering. It benefits the inmates and ensures the quality of production, as all workshops are ISO 9002 certified. Some of the instructors have been there for over 20 years, and virtually all are qualified to assess the NVQ programme. Productivity in engineering is particularly high. In 1998, when the work- 
shop expansion scheme called for an increase in productivity from 32 to 40 per cent, the average was already 77.40 per cent. ${ }^{217}$ The workshop hours also exceed the usual hours worked at Featherstone: 33.5 hours compared to an average of 28 hours. The sales are correspondingly high:

Table 18: Annual Sales Engineering, HMP Featherstone 218

\begin{tabular}{|l|l|l|l|}
\hline Year & Internal Sales & External Sales & Total \\
\hline $1996 / 97$ & $€ 1,566,979$ & $€ 166,926$ & $€ 1,733,905$ \\
& $£ 1,030,907$ & $£ 109,820$ & $£ 1,140,727$ \\
\hline 1997/98 (Workshop & $€ 1,949,533$ & $€ 206,908$ & $€ 2,156,442$ \\
Expansion Scheme & $£ 1,282,588$ & $£ 136,124$ & $£ 1,418,712$ \\
\hline $2000 / 2001$ & $€ 1,976,000$ & $€ 304,000$ & $€ 2,280,000$ \\
& $£ 1,300,000$ & $£ 200,000$ & $£ 1,500,000$ \\
\hline
\end{tabular}

As we can see from the above figures, sales increased by almost 25 per cent during the first year of the Workshop Expansion Scheme. Since then, increases have been more moderate and mainly limited to external sales.

The Textiles workshop provides work for 110 to 120 prisoners, the same as in engineering. Most of the eleven instructors are women. The workshop produces 8,000 garments for the internal market per week: t-shirts, trousers, vests, briefs and sweatshirts. It also supplies cut parts to other prisons and sells some of its production on the external market. The garments are of very good quality (Textiles had obtained the ISO 9002 certification even before engineering), able to withstand the rough treatment of prison laundries without shrinkage and other damage.

Sales figures for 2001 were around $£ 1,000,000(€ 1,500,000)$ of which $£ 80,000$ $(€ 120,000)$ were obtained through external contracts. If we compare these figures with 1997/98, the first year of the Workshop Expansion Scheme (total sales: $£ 928,168$, external sales: 14,000 ) we observe the same pattern as in engineering: a small overall increase, with a noticeable jump in external sales. Business figures are not as high as in engineering because of lower added value and lower productivity (around 30 per cent). Productivity will never approach the figures achieved in outside factories because the machines are chosen with the function of employing a

217 Information taken from an internal document: "Workshop Expansion Scheme (North), H.M.P. Featherstone, Year 2-Business Plan, 1998/99, Engineering Industry", p. 4.

218 The figures from 1996 to 1998 are taken from the same internal document, p. 14. The figures for 2000/2001 are an estimate that I was given while visiting the prison. 
maximum number of prisoners and not with the function of producing maximum output. Inmates too are less motivated. The work, though well paid (inmates can make up to $€ 37.5 / £ 25$ a week compared to $€ 18 / £ 12$ in engineering), is monotonous and perceived as something women do. Several inmates mentioned during interviews that they were mainly motivated by the female instructors, who were kind and motherly, and whom they did not want to disappoint. NVQ work, which might add some interest to the daily routine, is limited given the low skilled nature of most jobs. Frequent absences of workers to attend education classes or for visits or appointments also take their toll on productivity. In textiles, disruptions are particularly troublesome, as the production is split into different operations (seems, zippers, buttons, etc.) and each subsequent operation depends on the completion of the previous one.

Next to the prison is a 65 acre dairy farm with a herd of one hundred Holstein cows. Two farm instructors and 8 to 10 inmates take care of the feeding, cleaning, bedding and milking of the animals and the processing of the milk. The milk is pasteurised and packed in tetra packs at the farm. Most of it is for use within the Prison Service, a small amount for external sales.

Prison farms in general are going through a difficult period. Most are losing money. It is also increasingly difficult to find a sufficient number of inmates who have working-out permits and are interested in farm work. Many do not appreciate the unsocial milking hours (the working day begins at $5.30 \mathrm{a} . \mathrm{m}$. and never ends before 5 p.m.), and do not enjoy the contact with animals. Others refuse because there is too much pressure to bring in drugs. Last but not least, for most inmates there is no professional future in this field. Not only is the number of jobs in farming steadily declining, but most prisoners are city dwellers who would never consider working on a farm.

Only ten years ago, the dairy farm employed over forty inmates. Thirty others were bussed every day to Newbrook Farm, a prison farm some twenty miles away that specialises in rare breeds of farm animals (sheep, cows, pigs) and is open to visitors. A small shop displays prison products and souvenirs. At the time, it was considered an ideal placement for long-term prisoners who had reached the end of their sentence and needed to get used to contact with people on the outside. They were put in charge of the shop or used as guides, and no incident was ever reported. With present concerns about security, the bussing has stopped, and a category D prison has taken over the management of Newbrook.

\section{b) Service sector activities}

A small number of inmates work in the service sector. Four to five inmates sanitise counterfeit clothing confiscated by the Trading Standards Department. They remove the fake trademarks from the garments that are then sold in the charity 
shops of the Children's Aid Society. The work is painstaking, as most trademarks are embroidered into the tissue, and badly paid ( $€ 6.00$ to $€ 12.40 / £ 4.00$ to $£ 8.25$ per week), yet inmates value it for its social usefulness: in only two months they manage to sanitised garments with a resale value of $€ 34,500 / £ 23,000$.

Four inmates take care of desktop publishing of internal documents. Again the pay is not very attractive despite the skills required (€9.75/£6.50 which is the standard pay in education), but there are other compensations: the work is interesting and leaves room for individual creativity. It also opens access to computer time, a precious commodity in a system that does not allow inmates to have their own PCs.

Two other inmates are in charge of the raptor project. This was once a flourishing project in which wounded raptors were brought to the prison and cared for by inmates until they were fit to return to freedom. Budget cuts and a lack of prisoners interested in the care of birds have reduced it to a marginal activity.

c) Domestic and maintenance tasks

85 inmates take care of domestic tasks (kitchen, laundry, cleaning, etc.) The pay scale, cooks excepted, can hardly be described as attractive (€6.00 to $€ 12.30$ or $£ 4.00$ to£ 8.20 per week), but there is no shortage of applicants. Three reasons were given during interviews: 1 . Anything is better than to be locked up for most of the day, 2. Domestic jobs give greater freedom of movement than work in industry, and 3. It is a good way to get to be known by the officers which, in a large prison like Featherstone, is no mean advantage when it comes to a recommendation for day leave or parole.

\section{d) Vocational training}

Vocational qualifications are mainly obtained on the job and are available in most workplaces (NVQs in engineering, textiles, milking, catering and hospitality, and barbering). The only two full-time vocational training courses, in milling and lathe tuning, had been temporarily suspended, as the equipment no longer met the required safety standards. There were plans to combine the two courses and use the freed space for a course in forklift driving combined with NVQs in warehousing. Training in industrial cleaning has been applied for and will go ahead, as soon as the funding is forthcoming. The gym section also offers several shorter training options, for instance a certificate as community sports leader.

\section{Comments}

Featherstone has much to offer: spacious and purpose built workshops, a vast farm, dedicated and qualified instructors who manage to create working conditions 
resembling as closely as possible those on the outside. In 2002, it was chosen as one of four establishments to pilot the "jobpoint" scheme, in which prisoners close to release could access a national database of job vacancies and receive support in completing job applications and attending an interview. ${ }^{219}$ Work, unfortunately, is hampered by structural problems beyond the control of the local team, foremost by the lack of sufficient work or training places. During her last short follow-up inspection (2005), the Chief Inspector criticised the prison for not performing sufficiently well in two areas: respect and purposeful activity. ${ }^{220}$ In a previous report, ${ }^{221}$ the Inspector had commented on the high percentage of inmates ( 22 per cent) without a job who remained locked up for much of the working day. The narrow spread of vocational training had also been criticized, and branching out into the service industry (catering, industrial cleaning) had been recommended.

Two of the three main industries at Featherstone are a matter for concern. Work in textiles is relatively low skilled, repetitive and offers no job prospects on the outside. Farming faces similar problems: though the work is more varied, it appeals to few inmates and the professional outlook is bleak. Yet Headquarters are reluctant to make drastic changes. In the words of a manager of Enterprise Supply Services: "In any decision to maintain or to close down an industry, three factors have to be taken into consideration: 1. Is the industry useful for the Prison Service? 2. Is it useful for the prison concerned? 3. Is it useful for the inmates?" In the case of textiles, two out of three factors speak in favour of the status quo. It helps balancing the books of the Prison Service by providing low-cost clothing, and it keeps a large number of inmates busy without costly equipment and without long training periods. The Prison Service regrets that inmates do not get more useful training but sees no possibility to replace textiles by other industries. A more radical reform of farming seems more likely, as it is falling short of all three requirements: it is a money-losing proposition and the effort is hardly worth while for eight inmates who have no intention of ever working on a farm. The immediate plans are to change from dairy farming to cattle raising, which is considerably less labour intensive and probably more profitable.

What about the concept of an industrial prison? It has been criticised for putting too much emphasis on work while neglecting the other treatment needs of the inmates. This may be true for prisoners who lack basic skills or have serious behavioural problems. But there are many others for whom an industrial setting is helpful and appropriate. These include those with longer sentences, who already have key skills qualifications and have addressed their offending behaviour, as well as shortterm prisoners who do not want further education and training but need to maintain

219 Leech (2006), Prisons Handbook, p. 134.

220 HM Chief Inspector of Prisons (2007), p. 80.

${ }^{221}$ HM Chief Inspector of Prisons (2001), p.11. 
good work habits. Follow-up studies ${ }^{222}$ show how difficult it is for ex-inmates to find employment. Their chances are even slimmer if they have never been exposed to working conditions akin to outside standards while inside. Those establishments that strive to provide such a work environment deserve to be encouraged as much as possible.

The statistics for 2007 show a marked improvement in the paid activity rate. Despite an increase in the prison population of 13.4 per cent since 2002 , the paid activity rate (work, training, education) managed to rise from 75 per cent to 83.8 per cent, the highest of the nine prisons. This positive evolution is due to three factors: the availability of more workplaces in industries ${ }^{223}$, a greater emphasis on parttime work combined with education, and a noticeable increase ( 83.5 per cent) of jobs in the domestic sector. Featherstone has thus gone a long way to correct a major criticism about the number of prisoners left without constructive activities contained in the 2005 assessment of the Chief Inspector of Prisons. ${ }^{224}$ Less clear is whether Featherstone still deserves to be called an industrial prison or whether it is now on par with other prisons where industrial work is just one activity among others.

\section{HMP Swaleside}

\section{General information about the prison}

HMP Swaleside is a category B training prison for adult male prisoners sentenced to four years or more. It is situated on the Isle of Sheppey, a small island in the Thames estuary. Though the location itself is isolated, the Isle of Sheppey is well connected by road to the neighbouring prosperous centres of Maidstone and Canterbury. It also has good links to the channel docks.

The prison opened in 1988 and was originally conceived for 500 prisoners living in four residential units. A fifth wing was added in 1998 as a drug treatment unit, housing 120 prisoners. One more wing opened in 1999 to accommodate 120 first stage lifers. In July 2002, the prison held 770 inmates, ${ }^{225}$ about 300 (39 per cent) of which are first and second stage life-sentenced prisoners. ${ }^{226}$ At 36 per cent, the

222 Hammerschick/Pilgram/Riesenfelder (1997), in: Hammerschick/Pilgram, p. 166. Simon (1999), Prisoners' Work, p. 165. Mair/May (1997), Offenders on Probation, p. 134.

223 It is difficult to put a precise figure on the increase as the statistics provided do not distinguish between full-time and part-time jobs.

224 HM Chief Inspector of Prisons (2007), p. 80.

225 Certified normal allocation (i.e., one prisoner per cell): 747; operational capacity (i.e., maximum number that can be safely accommodated): 777 .

226 The English system distinguishes between, first, second, and third stage lifers. During the first third of the tariff period, lifers are particularly vulnerable, as many have not yet come to terms with the length of their sentence. During the second stage, they are usually moved to a different prison, often to a lower security category. The third stage is focused on resettlement, and should normally be served in a category $\mathrm{C}$ or D establishment. 
number of ethnic minority inmates is high, 182 of whom are foreign nationals. The prison has a reputation of being the toughest category B prison in the country, and this in more than one way: it receives a disproportionate share of "tough" inmates because the prison is considered particularly safe. 85 per cent serve sentences of over eight years and most have been to other prisons before. It is also tough in the sense that living conditions and staff-inmate relationships are less favourable than in the other prisons I visited. Swaleside could be described as a prison of contrasts where pockets of excellence (the health care centre, regime activities like physical education or offending behaviour courses, the Kainos programme ${ }^{227}$ ) compensate for shortcomings in other fields.

\section{Work and Training}

The same contrast can be observed in work and training. Swaleside has the highest percentage of unskilled jobs of the nine prisons visited but offers among the highest wages in its PFI (Private Finance Industries) workshops to be found in any English prison. The normal ratio of internal and external contracts has been inverted: Swaleside has virtually done away with traditional Prison Industries. It has also inverted the proportion between housekeeping jobs and industrial work, employing 45.7 per cent of working inmates in a domestic capacity. ${ }^{228}$ At the time of our inquiry, the NVQ programme had virtually collapsed (the only NVQs on offer were in education), yet the training units, even without external qualifications, provided quality training throughout.

In 2002, 169 inmates were employed in industrial workshops, 202 in housekeeping and maintenance, 71 were in vocational training, including computer training, and 103 in education. This translates into an employment rate of 57.4 per cent (442 of 770) or 70.8 per cent (545 of 770) if we include the full-time students. Of the remaining 225 inmates, not all were unemployed: 71 were on the waiting list for a job opening, 27 refused to work or had been fired, and the remainder took part in some form of treatment programme: drug unit (54), offending behaviour programmes (40), and the four-month Kainos course (30).

The span of the pay scale is unusually large for England: Whereas wing cleaners (£8.50 per week), contract workers on standard regime (£10 to £12), and inmates working in engineering (£13.60) are at the lower end, inmates in the PFI shops are on enhanced pay and earn anywhere between $£ 40-£ 60$ ( $€ 60$ and $€ 90)$.

227 The Kainos Community is a Christian-based rehabilitation unit where 30 men live together in a non-threatening, caring community. The programme is open to all creeds; the only condition is a willingness to change. The course lasts four months, but some vulnerable prisoners are allowed to stay on longer.

228 The Chief Inspector in her report puts the figure even higher at 52 per cent. (July 2002), p. 75. 
Table 19: Paid activities at HMP Swaleside

\begin{tabular}{|l|l|l|l|l|l|l|l|}
\hline Activities & $\begin{array}{l}\text { Enginee- } \\
\text { ring }\end{array}$ & $\begin{array}{l}\text { Contract } \\
\text { Work, } \\
\text { standard }\end{array}$ & $\begin{array}{l}4 \quad \text { PFI } \\
\text { shops }\end{array}$ & $\begin{array}{l}\text { Do- } \\
\text { mestic } \\
\text { tasks }\end{array}$ & $\begin{array}{l}\text { Vocational } \\
\text { training }\end{array}$ & Education & Total \\
\hline $\begin{array}{l}\text { Number } \\
\text { of jobs }\end{array}$ & 11 & 42 & 116 & 202 & 71 & $(103)$ & 442 \\
\hline $\begin{array}{l}\text { \% of paid } \\
\text { activities }\end{array}$ & $2.5 \%$ & $9.5 \%$ & $26.2 \%$ & $45.7 \%$ & $16 \%$ & $(545)$ \\
\hline $\begin{array}{l}\text { \% of the } \\
\text { population } \\
(770)\end{array}$ & $1.4 \%$ & $5.5 \%$ & $15.1 \%$ & $26.2 \%$ & $9.2 \%$ & $(13.4 \%)$ & $\mathbf{5 9 . 2 \%}$ \\
\hline
\end{tabular}

The numbers in brackets include the remunerated educational activities.

The Activity Allocation Board consists of the Head of Prison Development, the education manager, and sometimes a personal officer. The board meets once a week and considers roughly 40 applications each time. Theoretically, the board takes into consideration the prisoner's needs and wishes, his security requirements, his abilities and skills, his wing record as well as his health and work record. The criteria vary, however, according to the job or activity applied for: the well paying PFI jobs are only open to candidates who are on enhanced status and have certain educational standards.

There are no written guidelines for work related sanctions, including firing; at least they were not made available when asked for. When inquiring about the complaints of two inmates threatened with dismissal from their PFI job for not wanting to work on a bank holiday (without extra pay and while the other three PFI shop workers and all the other inmates were given the day off), I was told by the then Head of Prison Development that this simply reflected outside practice and prisoners had better get used to it.

\section{a) Industrial production}

In May 2002, 6 industrial workshops were operational. The output of five of them was destined exclusively for the external market, and only one, a small engineering shop, still produced goods for the Prison Service.

In the prison-run engineering section, 12 inmates produced, under the supervision of one instructor, a variety of items for the prison estate: metal gates, window grills and fire escapes and, time permitting, also products for external customers. The workshop used to be a training unit with two instructors teaching basic engineering skills that led to NVQs level 1 and 2. In a move to rationalize prison la- 
bour, one instructor was assigned to other duties, and the workshop converted into a pure production unit. ${ }^{229}$ The workshop hours are from 9.00 a.m. to 12.15 p.m. and from 2.00 p.m. to 4.20 p.m. Inmates who perform below level two in basic and key skills can spend two paid sessions in education without loss of pay.

The vast majority of production jobs are provided through contract work of which there are two types at Swaleside: Private Finance Industry (PFI) workshops and a light assembly workshop run by prison personnel.

169 inmates (68 per cent of industrial workers) work in PFI workshops. The common practice in Britain is for customers to subcontract work to prisons or to place orders for items to be produced by prison workshops. At Swaleside external companies actually rent prison space, employ prison manpower and manage the activities using their own staff - very much the way contract work is handled in France and Germany. The plan to attract PFI contracts goes back to the late nineties, when Swaleside was faced with two major challenges: an increase in prison population from 500 to over 700, and a tightening of the prison budget. PFIs seemed, from the administration's point of view, a good solution. Floor space, previously taken up by workshops or training units, could accommodate a much larger number of workers if converted into assembly or textile shops. This at no extra cost to the prison, as equipment, material and management was to be provided by the contracting company. Better still, the prison would increase its own budget, as it could keep part of the benefit of the operations, ${ }^{230}$ a practice that does not apply to benefits (or savings) on items produced for the internal market. There remained, however, the problem of how to attract suitable companies. The then Head of Prison Development reasoned that Swaleside had to offer more than good logistics (vicinity to industries and docks; a good road network; vehicle access even for articulated lorries; sufficient storage space) to attract business. Companies wanted to be sure that the workforce was well disciplined, competent and productive. Hence the plan of using tight selection criteria for the workers 231 and of introducing a continuous workday from 9.00 a.m. to 4.20 p.m. with two short tea breaks and lunch taken in common in the workshop. In return, workers would get enhanced wages and an integrated bonus system for the whole workshop. The strategy proved successful, with four PFIs firmly established and negotiations with a fifth progressing well at the time of my visit.

229 The adjacent wood workshop fared worse: it was closed from one day to the next, with the equipment and partly finished items left in place to gather dust.

230 Swaleside takes in receipts $£ 500,000(€ 750,000)$ from the four PFIs. This is more, according to the Head of Prison Development, than the receipts of all the other prisons in Kent and Sussex taken together.

231 All must be on enhanced status (excellent safety record, no adjudication or positive drug testing in 12 months) and have passed level 2 in basic literacy and numeracy skills. They also need references from two previous workplaces in prison and have to pass a job interview as would any outside worker. 
Work in all four shops requires little skill. In one workshop, inmates weigh and pack screws, nuts and bolts ready for retail, in another they make folders for filing cabinets, a third is busy with the assembly and packaging of guttering and, in the fourth, inmates cut and sew webbings for dock cranes. Supervision can thus be reduced to a minimum. In two workshops, there is only one instructor, one workshop has two (one a prison officer), and the largest one has three. For security purposes, two prison officers take turns patrolling the shops.

Working conditions are not worse than in a comparable unit outside, but the prison setting does amplify certain negative factors. Workshops, for instance, have no windows. Outside, workers are able to leave the premises during breaks and get some fresh air, but prisoners are locked in the workshop for close to seven and a half hours, taking their breaks in a small room partitioned off from the main workshop. Many inmates would prefer going back to their cells during lunch like their colleagues in engineering and light assembly but this is impossible as it would take a toll on the output with repercussions on salaries and, possibly, on the contracts themselves.

In 1999, again in an attempt to create jobs, floor space formerly occupied by vocational training in bricklaying was converted into a workshop providing unskilled light assembly work for 45 inmates on standard regime. Two instructors (one officer and one civilian) supervise the work, which is dull (labelling, stacking and packing plastic salad trays for a supermarket) and poorly paid. The productivity of the workshop is correspondingly low, though this may also have something to do with the characteristics of the workforce. ${ }^{232}$ The evaluation of the inmates is mixed: many consider light assembly preferable to being stuck on the wing as a cleaner or, worse, being unemployed. Others are more critical and complain about "slave labour". Good workers have a slight chance to be promoted to the PFI shop, but not very many succeed.

b) Domestic and maintenance jobs

Swaleside employs a large cleaning crew: 184 inmates (23 per cent of the total population) work in this or a related domestic capacity. According to a report by the Chief Inspector of Prisons, their performance does not always meet expectations. $^{233}$ Insufficient supervision by wing officers and low pay ( $€ 12.75$ to $€ 15 / £ 8.50$ to $£ 10.00$ per week) seem to be the main reasons. There is also no attempt to use the expertise of inmates having completed training in industrial cleaning.

232 The workshop basically takes in inmates on standard regime but also some who cannot keep up with the rhythm of PFI workshops, even if they fulfil the other criteria.

${ }^{233}$ HM Chief Inspector of Prisons $\left(15^{\text {th }}-19^{\text {th }}\right.$ July 2002), p. 16, 28. 
One area is, however, immaculately clean. This is the kitchen where 3 officerchefs, 11 civilian cooks, and 24 inmates are busy preparing three meals a day for 776 persons. Until a few years ago, inmates could work towards NVQs in catering and hospitality, but the staff no longer find the extra time for training and paperwork. It is not just that the number of meals has increased and that the choices of different diets are large (eight at lunch and seven for dinner), but that the equipment is dated and frequently breaks down. Despite these inconveniences, worker satisfaction is high. Inmates appreciate being responsible for food production and like the cheerful atmosphere. A French inmate with considerable expertise in "comparative penology" stressed the difference in tone between French and English prisons. He said he prefers earning less in England in exchange for being treated by his superiors like a capable co-worker.

\section{c) Vocational training}

At the time of my inquiry vocational training did not fare well. No national vocational qualifications were offered to the 150 prisoners working in the six production workshops or the 203 employed in cleaning and maintenance tasks. Physical education had to drop its excellent NVQ programme for 9 students, who also acted as gym assistants when staff numbers dropped from 9 to 3. Only the education department still offered general national vocational qualifications (GNVQs) in art and design, information technology, and a course in barbering (NVQ level 2). Full-time vocational training courses were reduced to two: painting and decorating (16 students), and industrial cleaning (10-12 students). Both fields open good job prospects and are very well taught. The particularly popular painting and decorating course used to award NVQs until one of the two instructors was assigned to other duties. The remaining instructor can still teach all the necessary skills, but the diploma has been reduced to a less prestigious crafts certificate.

No arrangement is made for prisoners to apply their skills once they have completed the course, though there would be plenty of scope both for painters and cleaners. In a neighbouring prison, inmates who have gone through the industrial cleaning course are valued as a precious resource, considering the fees outside firms charge for similar work (€9000/£6000 for cleaning an industrial kitchen the size of Swaleside's). Only two inmates have a job to clean up bio-hazardous body spills $^{234}$ for which they are paid $€ 45 / £ 30$ per week - professional cleaners charge ten times that amount for cleaning just one cell.

${ }^{234}$ Body spills of inmates who are HIV positive or suffer from other infectious diseases. 


\section{Comments}

Assessments of prisons by Her Majesty's Chief Inspector of Prisons are based on four criteria: safety, respect, purposeful activity and resettlement. When applied to work, the following conditions should be met:

1) Safety: Prisoners should work in a safe, suitable environment.

2) Respect: The range, type and availability of work activity should meet the needs of the prison population, and prisoners should be treated fairly in all aspects of their work, its allocation and pay.

3) Purposeful activity: Prisoners should be engaged in well-organised employment; work programmes should be fully integrated with residential units and other departments.

4) Resettlement and reducing re-offending: Prisoners should be occupied in realistic work that prepares them for employment on release and helps to reduce reoffending.

At HMP Swaleside, health and safety standards are overall satisfactory. As far as respect is concerned, the establishment fares less well. The range of work activities is too narrow and meets the needs of the prison rather than those of the prisoners. In the words of the Chief Inspector of Prisons: "The work opportunities available were often geared to generating income for the prison, rather than providing work skills for prisoners." 235 There is also not enough work, especially industrial work, to occupy the prison population. The pay span between the different jobs is perceived as unjust by the lower paid workers, the more so as access to the better paid jobs is severely limited. There are no written allocation guidelines and, worse, no guidelines for firing and other work-related disciplinary measures.

Purposeful activity has two facets: organisation and coordination. Nobody can criticise the work organisation, which is excellent, but coordination with other activities is poor or non-existent. No attempt is made to use the skills of inmates who have gone through professional training. Part-time education places have long waiting lists, and only domestic workers or inmates working in engineering or light assembly can get paid time off to improve their academic skills. PFI workers have to work the full ten periods per week. Finally, prison labour should prepare the inmates for employment on release and help reduce re-offending. This last point is the most problematic of the four. Only 24 per cent of prisoners believe that their work provides them with the skills and the experience that would be useful in finding a job on release. 236 It is therefore not surprising that the Chief Inspector of Prisons in her 2005-2006 report rates both the area of purposeful activities and resettle-

\footnotetext{
235 HM Chief Inspector of Prisons (2002), p.4.

236 Ibid. p.75.
} 
ment as not performing sufficiently well. ${ }^{237}$ This said, it is fair to add that few inmates in the enhanced workshops complain. There are even some who refuse a transfer to a category $\mathrm{C}$ establishment because they would never get the same pay. Yet it seems a pity that a well-disciplined, able and stable workforce like the one working in the PFI shops is not given a better chance. It should be possible to find contractors, like in France and Germany, willing to provide more satisfying work while maintaining the enhanced pay level.

HMP Swaleside is in many ways an exception among the nine research prisons. It is the only one to have attempted a radically new approach to prison labour and stands alone in having increased the pay of most of its industrial workers to a level unheard of in most English establishments. It has shown that even a so-called tough prison can deliver a well-disciplined and efficient work force, and that prison labour can be profitable. Despite these positive points employment at Swaleside has serious weaknesses. The transformation of the workshops was too radical and had little to do with enhancing the rehabilitation of the inmates, but was motivated by the need to find a solution to a financial crisis brought about by budget cuts. The price paid was too high, and a more moderate change, preserving a better equilibrium between Prison Industries and contract work, would have given better results.

The most recent statistics (June 2007) show signs of a more difficult economic context. The number of industrial work places has decreased from 169 to 131 since one of the PFI shops ended its contract with the prison. In exchange, full-time professional training has increased from 28 to 55, and 14 inmates are working on their NVQs on the job. Employment in the domestic sector has remained roughly constant (195 jobs), and 203 students are taking courses in Education, most on a parttime basis. The work and training rate is thus slightly lower at 52.3 per cent (414 places for 785 inmates) than in 2002, when it was 59.2 per cent. ${ }^{238}$

Stocktaking the situation of work and training in the nine research prisons has given us a better picture of the reality of prison labour, of its strong points as well as of its weaknesses. The most recent statistics confirm that a more difficult economic context and a general increase in the number of inmates have had a negative effect on employment figures, a trend already visible in 2002. Only two establishments (JVA Straubing and HMP Featherstone) have managed to increase the number of industrial workplaces and their overall paid activity rate. JVA Schwalmstadt can boast a slightly higher employment rate, but only because the increase in domestic jobs and vocational training have compensated the loss in the industrial sector. The other six prisons all show a decrease in the number of inmates gainfully employed.

${ }^{237}$ HM Chief Inspector of Prisons (2007), p. 81.

238 To the 55 places in industrial training workshops were added 33 computer programming places in Education, the same as in table 18. 


\section{Chapter 2: Prison Labour Seen From the Inmates' Point of View}

One of the key objectives of my research was to find out more about the expectations of prisoners and their attitude to work. In all, 526 inmates filled in the questionnaire, and 92 agreed to be interviewed. The information obtained gave me a vivid and often unexpected picture of the way inmates assess their work. I mainly examined three areas: the inmates' previous professional record and their motivation for working; the connection they made between their prison jobs and future chances of employment, and the improvements they would like to see.

\section{Previous Work Record and Actual Motivation}

\section{A. Professional Background}

The first preconceived idea I had to give up when reading the professional records of the workers was that of a homogenous population of "inmates at work". There is a great diversity of former employment patterns and a wide range of training levels, from unskilled labourers to university graduates. The popular stereotype of lazy inmates who have little to offer in the way of employability is at best a halftruth. Two-thirds of the French and German inmates and 45 per cent of the English prisoners had worked, at least part of the time, during the year before their arrest. Nevertheless, the percentage of inmates that have gone through a period of unemployment during the same period is four to eleven times higher than for the population at large. ${ }^{239}$ This rate is the highest in England, which has the lowest unemployment rate for its general population.

As for their professional qualifications, the following results were obtained:

Table 20: Professional qualifications

\begin{tabular}{|l|c|l|l|}
\hline & France & Germany & England \\
\hline Self employed & $19.2 \%$ & $32.5 \%$ & $24.4 \%$ \\
\hline Semiskilled labour & $17.8 \%$ & $15.6 \%$ & $21.8 \%$ \\
\hline Skilled lbour/craftsman & $42.5 \%$ & $42.9 \%$ & $35.9 \%$ \\
\hline Other & $13.7 \%$ & $11.1 \%$ & $8.3 \%$ \\
\hline Without employment & $13.7 \%$ & $6.9 \%$ & $21.8 \%$ \\
\hline
\end{tabular}

239 France: general population: $9.2 \%$; inmates: $33.8 \%$; Germany: general population: 9.1\%; inmates: 32.6\%; England: general population: 5\%; inmates 55\%. Source for general population: Eurostat, News Release, January 2006. 
Germany has the highest rate of self-employed workers and the lowest percentage of inmates without employment. Nearly $43 \%$ are skilled workers and craftsmen, roughly on a par with France. The percentage of less qualified inmates, i.e., semiskilled workers or persons without professional qualification, is considerably higher in England: 43.6 per cent compared to 31.5 per cent for France and 22.5 per cent for Germany.

\section{B. Reasons for working}

Why do inmates work? In Germany and England, inmates work because they have no choice. But is this their only reason? The answers to the questionnaire indicate the contrary: only 15.7 per cent of German inmate workers and 7.8 per cent of the English sample mention the mandatory nature of work in first place. Table 21 gives a summary of the principal reasons given, combining the answers of all three countries.

\section{Work, an economic necessity}

Table 21: Reasons for working, all three countries combined

\begin{tabular}{|l|c|c|c|}
\hline \multicolumn{1}{|c|}{ Reasons } & $\begin{array}{l}\text { Number of ans- } \\
\text { wers }\end{array}$ & \% of answers & $\%$ of cases \\
\hline 1. Work is mandatory & 70 & 5.6 & 16.2 \\
\hline 2. Remuneration & 264 & 21.2 & 61,0 \\
\hline 3. Getting out of the cell & 208 & 16.7 & 48.0 \\
\hline $\begin{array}{l}\text { 4. Human contact } \\
\text { 5. In order to learn }\end{array}$ & 145 & 1.6 & 4.6 \\
\hline $\begin{array}{l}\text { 6. More humane treat- } \\
\text { ment than on cell block }\end{array}$ & 86 & 11.5 & 19.9 \\
\hline $\begin{array}{l}\text { 7. To forget, find distrac- } \\
\text { tion }\end{array}$ & 67 & 5.4 & 15.5 \\
\hline $\begin{array}{l}\text { 8. To spend, structure } \\
\text { one's time }\end{array}$ & 222 & 17.9 & 20.3 \\
\hline $\begin{array}{l}\text { 9. To obtain sentence } \\
\text { adjustments (permits, } \\
\text { parole) }\end{array}$ & 73 & 5.9 & 287.1 \\
\hline $\begin{array}{l}\text { 10. Others, such as } \\
\text { searching satisfaction } \\
\text { through work }\end{array}$ & 1243 & 100.0 & \\
\hline $\begin{array}{l}\text { Total } \\
\text { To read the table: of all }\end{array}$ & 88 & & \\
\hline
\end{tabular}

To read the table: of all answers, 5.6 per cent dealt with the obligation to work. Of all people questioned, 16.2 per cent said that they worked because they had to. 
"[Work in prison is] essential for the inmates as it more often than not constitutes for them their only means of subsistence. Life in a prison is not free, and poverty inside is sharper than outside." 240 This assessment by Senator Loridant summarises the pressing need felt by most inmates for job classification. Indeed, 61 per cent of all answers mentioned economic considerations and 36.6 per cent quote it as their main motive.

For many people unfamiliar with prisons, this concern with the financial advantages of work comes as a surprise as "prisoners are already given everything they need." The following testimony of a French inmate bears witness to the fact that this "everything" is nonetheless insufficient:

Contrary to preconceived ideas, everything has a price in prison. The inmate has to buy hygiene and cleaning products: toothpaste, shampoo, even toilet paper. If you want to improve your diet (coffee, sugar, chocolate, spices) or if you smoke, you need money. If you want to study, you need money again, as there are no scholarships for students. The television rental amounts to $€ 32.50$ and the fridge rental to $€ 7.50$ per month. Furthermore, you may have to buy clothes; you are expected to make restitution payments (amounting on average to €15). In short, I should say $€ 120$ are barely enough to get by.

This estimate, far from being exaggerated, is confirmed by the Loridant Report 241 that estimates that a French prisoner needs at least 150 to 200 euros per month. Money is not only needed to buy personal goods. About 10 per cent of the inmates interviewed mentioned that they worked in order to help their families at home, and four respondents indicated that they wanted to compensate their victims.

\section{An activity that structures the day and gets inmates out of their cells}

Inmates were asked to list, in decreasing order, the three most important reasons for wanting to work. In the category "most important reason for working", most votes went to economic considerations ( 36.6 percent), followed by the fact that it allowed them to get out of their cell (15.7 per cent) and, third, because work was mandatory (10.9 per cent).

The motive most frequently quoted as the second most important reason for working is the fact that a job allows inmates to leave the confines of their cells (21.8 per cent). For third most important reason, most votes went to work helping to organise the day and to pass the time (31.1 per cent).

\footnotetext{
240 Rapport Loridant (2002), p.6.

${ }^{241}$ Loridant (2002), p. 34.
} 
Table 22: Most important reason for working

\begin{tabular}{|l|c|c|c|}
\hline \multicolumn{1}{|c|}{ Reason } & Frequency & Percentage & \% valid \\
\hline 1. Remuneration & 158 & 30.0 & $\mathbf{3 6 . 6}(1)$ \\
\hline 2. Being out of the cell & 68 & 12.9 & $15.7(2)$ \\
\hline 3. Mandatory work & 47 & 8.9 & $10.9(3)$ \\
\hline 5. To learn & 38 & 7.2 & $8.8(4)$ \\
\hline $\begin{array}{l}\text { 6. To pass, structure } \\
\text { the time }\end{array}$ & 33 & 6.3 & 7.6 \\
\hline $\begin{array}{l}\text { 7. Better treatment } \\
\text { 8. To obtain sentence } \\
\text { adjustments }\end{array}$ & 23 & 4.4 & 5.3 \\
\hline $\begin{array}{l}\text { 9. To forget about } \\
\text { being in prison }\end{array}$ & 12 & 2.5 & 2.0 \\
\hline 10. Others & 40 & 2.3 & 9.3 \\
\hline Total & 432 & 7.6 & 100.0 \\
\hline Missing answers & 94 & 17.9 & \\
\hline Total & 526 & 100.0 & \\
\hline
\end{tabular}

Table 23: Three main reasons for working, country by country

\begin{tabular}{|l|lc|cc|cc|cc|}
\hline Main reasons & \multicolumn{2}{|c|}{ Total \% } & \multicolumn{2}{|c|}{ France } & \multicolumn{2}{|c|}{ Germany } & \multicolumn{2}{|c|}{ England } \\
\hline Remuneration & 61 & $(1)$ & 80.9 & $(1)$ & 59.3 & $(1)$ & 53.5 & $(1)$ \\
\hline $\begin{array}{l}\text { To pass/structure } \\
\text { the time }\end{array}$ & 51.3 & $(2)$ & 50 & $(2)$ & 50.8 & $(2)$ & 52.7 & $(2)$ \\
\hline $\begin{array}{l}\text { To get out of the } \\
\text { cell }\end{array}$ & 48.0 & $(3)$ & 42.6 & $(3)$ & 49.6 & $(3)$ & 48.1 & $(3)$ \\
\hline To learn & 33.5 & $(4)$ & 16.2 & $(6)$ & 34.7 & $(4)$ & 40.3 & $(4)$ \\
\hline Others & 20.3 & $(5)$ & 27.9 & $(5)$ & 21.2 & $(5)$ & 14.7 & $(7)$ \\
\hline Better treatment & 19.9 & $(6)$ & 7.4 & $(10)$ & 21.2 & $(5)$ & 24.0 & $(5)$ \\
\hline $\begin{array}{l}\text { Sentence ad- } \\
\text { justments }\end{array}$ & 19.9 & $(7)$ & 39.7 & $(4)$ & 9.7 & $(9)$ & 17.8 & $(6)$ \\
\hline
\end{tabular}

To read the table: of all the people interviewed, 61 per cent said they were working to finance their needs. The figures in brackets represent the rank. 
By comparing the answers for the three countries (table 23), we can see significant differences: inmates agree on the three main motives for working (1. remuneration, 2. to pass/structure time, 3. to leave their cells), but the percentages vary from country to country. The number of inmates motivated by pecuniary considerations is much higher in France than in Germany or in England. This may be attributed to a higher pay level and a more urgent need for funds to compensate for insufficient supplies handed out by the prison authorities. Interesting is also that the gap between the first three answers is considerably more pronounced in France than in the other two countries.

\section{Other reasons for working}

Learning through work is a powerful motivation in England, where 40.3 per cent of the workers mention that they work in the hope to improve their job skills. The number of German inmates ticking this box is still high at 34.7 per cent, but the fact that only 16.2 per cent of French inmates do so is troubling. The explanation may have to do with the way training is organised in the three countries. With its system of national vocational qualifications (NVQs, level 1, 2 and 3) England has developed a model that is well adapted to the needs of many inmates. It enables them to combine work with acknowledged training programmes given on the job, and workers are encouraged to improve their basic education by attending classes two half-days a week without loss of pay. In Germany, most prison-run workshops offer training schemes of variable duration; this is however rarely the case for contract work. Schooling during working hours is strictly reserved for the illiterate. As far as learning through work is concerned, French prisoners are even less lucky: nearly 90 per cent of production jobs demand few or no qualifications, thus severely reducing the opportunities for on the job training. As for traditional full time training programmes, the three French establishments in our sample were only able to supply a limited choice of one or two. There is also no question of a holistic approach to regime activities that would allow inmates to attend classes during working hours.

One out of five inmates in the German sample and nearly one in four in England work because they feel better treated in the workshop than on their cellblock, "more like any other worker and not like prisoners." This percentage is much lower in France ( 7.4 per cent), and ranks in last place. It could be that the masterinstructors or qualified outside staff that supervises the prison-run workshops under the German and English systems create a more welcoming and professional atmosphere than is the case in France.

The hope of obtaining a sentence adjustment by working is strongest in France, not because judges pay particular attention to work performance, but because pay- 
ment of damages to injured parties is a conditio sine qua non for granting measures such as parole or semi-liberty, and work is often the only way to comply with this requirement.

\section{Productivity}

Many prison workshops are afflicted with a productivity rate that is well below that achieved extra muros. This rate seems to be lowest in Germany, i.e., between 15 per cent and 20 per cent of external productivity. ${ }^{242}$ Figures from England are slightly better: 20 to 24 per cent in textile workshops, and 30 to 40 per cent or higher in engineering. ${ }^{243}$ The highest rate goes to French prisons that claim to have an average productivity rate of between 40 and 50 per cent. I reserve for a later chapter a more critical appreciation of these figures. ${ }^{244}$ At this point, the focus is exclusively on the reaction of inmates when confronted with this problem.

To the question: "Is it true, in your opinion, that workers work harder outside and produce more?" only 17.1 per cent of French inmates and 22 per cent of German inmates $^{245}$ gave an affirmative answer, as opposed to 34.4 per cent of the English. But even in England, nearly two thirds believed that prisoners work just as well and are just as productive as free labour. This positive auto-evaluation of the inmate workers came as a surprise. It is true that the question had focused exclusively on the labour aspect of productivity, without any mention of other factors affecting output such as the quality of equipment or workshop organisation. To get a more balanced picture, a second question was added: "If we assume for a moment that the above statement [i.e., that the productivity is lower] is at least partly true, what could be the reasons why prisoners produce less than outside workers?" The answers provided yet another surprise: the reason most often quoted was not the lack of financial incentives, which ranked in second position with 70.6 per cent of all answers, but the priority given to considerations of security and prison routine to the detriment of efficiency. 80.7 per cent of interviewees put lack of competitiveness down to waste of time for security controls and to short working days. The cause for this latter, as they saw it, was that shifts and lunch breaks of the prison staff had to be accommodated first. Close to half (46.2 per cent) felt that the managerial staff did not expect as much from the workers as would external employers. The question of productivity clearly interested the inmates since 69 per cent made

242 Dünkel (1999), in: van Zyl Smit/Dünkel (eds.), p. 87. Fulton/Smartt (1996), Prison Service Journal, p. 5.

243 Smartt/Vagg (1998), Prison Service Journal, p.8

244 Part IV, chap.1, p. 191.

245 Only the establishment in Hesse, with 33.7 per cent, was closer to English values. 
the effort to answer the open question "other reasons". Their criticisms were to the point and deserve to be mentioned in greater detail:

1) External motivation. Quite apart from the lack of financial incentives, there is no concrete link between good performance on the job and rewards granted in terms of sentence adjustments or privileges such as out of cell time after work. The same is true of internal motivation: most jobs offer no intrinsic satisfaction. But the lack of motivation is not always directly job-related: inmates feel overwhelmed by their personal problems and too depressed to concentrate on their tasks.

2) The working climate leaves a lot to be desired. Initiatives taken by inmates are viewed with suspicion. They are rarely asked for their opinion, and in general their efforts are barely acknowledged. The prison management pays little attention to physical comfort, such as temperature, light levels or noise control in spite of their repercussions on motivation.

3) Fluctuations in orders and the associated risk of being laid off are experienced as destabilising factors.

4) The organisation of work is often criticised: outdated methods, mediocre equipment, and a general lack of flexibility and innovation. Tasks that could be accomplished by one worker are given to two or three inmates to compensate for the low level of orders.

5) Some workers denigrate the insufficient training of their instructors, but the majority praise the good rapport with the supervisors and the workshop foremen.

6) The know-how of the workers is not sufficiently put to use. They are given jobs that do not match their professional qualifications, either for the convenience of the managing staff or because there are no other openings. An outside firm could never afford such an inefficient use of its human resources.

In short, prisoners have precise and intelligent ideas about the weak points of workshop organisation and human resources management, even if they may overestimate their own contribution.

\section{The Link between Work in Prison and Professional Reintegration}

How do inmates see the connection between work in prison and professional chances after release? There were two questions on this topic, the first inquiring about qualifications and skills acquired while working, the second touching upon expectations about a professional future. I also wanted to know how the unemployed saw their future prospects. 


\section{A. Work as a learning experience}

When asked whether they acquired new knowledge and useful skills that would help them find employment after their release, 58.3 per cent of the respondents gave a positive answer. They declared that they had learned a lot (23.6 per cent) or at least something (34.7 per cent) through their professional activity in prison. There were no significant national differences, but two establishments stood out from the rest: the detention centre at Montmédy and the JVA Schwalmstadt. Montmédy for a negative reason: 71.5 per cent of the inmates stated that work had contributed very little or not at all to increase their know-how; JVA Schwalmstadt, because it got higher marks than any other establishment: 77.7 per cent of respondents said that they had learnt new skills that would make them more attractive to employers.

How does work contribute to learning? In the three countries, the acquisition or improvement of technical or craftsman's skills is mentioned first (74.2 per cent), followed by maintaining previous know-how (64.3 per cent) and greater appreciation for a job well done ( 63 per cent). The latter ranks on a par with the ability to work in a team. English (66.7 per cent) and French prisoners (60.5 per cent) also highlight psychological aspects: they learn not to get so easily upset when confronted with obstacles, and to keep their cool in dealing with ill-tempered coworkers or instructors.

The open question "other skills" received many answers: $80.4 \%$ of the respondents wished to add skills that were not on the checklist. The following were mentioned:

1) Development of personal qualities: self-assurance, patience, equanimity, assiduity, a sense of self-criticism, better communication with others, and the desire to learn (28.1 per cent).

2) Survival strategies: becoming more cynical and indifferent, learning to hide one's true feelings, to dissimulate, not to trust anyone, to accept the inconveniences of work, to limit one's expectations, and to keep quiet (20.8 per cent).

3) Acquiring professional knowledge in a new domain (19.8 per cent).

4) Aiming for a recognised diploma (19.7 per cent).

5) Acquiring organisational skills, such as learning to solve technical problems, to make decisions and to be responsible for other less experienced inmates ( 9.4 per cent).

If it is encouraging to see that inmates do learn on the job, it is less so to find out that one fifth of the respondents include somewhat dubious survival strategies among the skills they have acquired, such as learning to dissimulate and to shut up. 
Table 24: Reasons given for having learnt little or nothing while working or in training

\begin{tabular}{|l|c|c|c|c|}
\hline & All countries & France & Germany & England \\
\hline $\begin{array}{l}\text { Jobs are such that } \\
\text { you do not learn } \\
\text { anything }\end{array}$ & $38.7 \%$ & $57.4 \%$ & $30.6 \%$ & $45.3 \%$ \\
\hline $\begin{array}{l}\text { Because I was } \\
\text { never given an } \\
\text { interesting job }\end{array}$ & $32.3 \%$ & $40.9 \%$ & $33.8 \%$ & $25.5 \%$ \\
\hline $\begin{array}{l}\text { No interesting trai- } \\
\text { ning offered }\end{array}$ & $48.4 \%$ & $76.0 \%$ & $40.9 \%$ & $50.4 \%$ \\
\hline Others & $74,4 \%$ & $70.3 \%$ & $72.8 \%$ & $77.9 \%$ \\
\hline
\end{tabular}

To read the table: $38.7 \%$ of all respondents think that the jobs are such that you cannot learn anything from them.

When we look at the answers given by workers who claim to have learnt little or nothing, national differences emerge: The level of dissatisfaction with the learning aspect of work is more pronounced in France than in Germany or England. The harsh criticism of French inmates concerning the unskilled nature of their jobs and the lack of professional training opportunities confirms the concerns voiced by the various reports quoted earlier. ${ }^{246}$

In the "other" category, 43.6 per cent of answers dealt with training, and focused mainly on the fact that the offer matched neither the market demand nor the interests of the inmates. 24 per cent criticised the nature and organisation of work, which left no leeway for initiative or creativity, and 14 per cent blamed the administration for "not giving a damn" and making no effort to set up appropriate training structures. Nearly 10 per cent thought they already knew everything and had nothing more to learn, whereas 9 per cent felt too old to learn anything new.

\section{B. Expectations about a professional future}

Research on the professional future of ex-inmates draws a bleak picture as to their chances on the labour market. According to the Austrian and British studies quoted in part 1,247 at best 25 per cent of ex-prisoners will find a stable, full-time

\footnotetext{
246 Assemblée nationale (2000); Sénat, (2000); Loridant (2002); Talandier (1987).

247 Part 1, chap. 1, A, 3.
} 
job in the first year following their release from prison. The majority of inmates interviewed seemed quite oblivious of their poor prospects: 63 per cent thought they would have little trouble in finding work, mainly because they were good workers and knew their job well. This overoptimistic evaluation of their future prospects and of their work performance is puzzling. It may be some kind of survival strategy, as inmates cannot face the prospect of closed doors upon liberation when their present state seems hardly bearable.

The comparison between the countries is again interesting: There is general agreement among inmates that it is their know-how and the network of family and friends that is going to help them find a job.

Table 25: Reasons why inmates are optimistic about finding a job after release

\begin{tabular}{|l|c|c|c|c|}
\hline & Together & France & Germany & England \\
\hline $\begin{array}{l}\text { Works well/ } \\
\text { knows job well }\end{array}$ & $95.9 \%$ & $100 \%$ & $95.5 \%$ & $94.4 \%$ \\
\hline $\begin{array}{l}\text { Relatives/friends } \\
\text { will help in find- } \\
\text { ing work }\end{array}$ & $77.2 \%$ & $68.1 \%$ & $77.8 \%$ & $80.0 \%$ \\
\hline $\begin{array}{l}\text { Resettlement } \\
\text { agencies will set } \\
\text { up contacts }\end{array}$ & $19.3 \%$ & $22.5 \%$ & $9.6 \%$ & $40.3 \%$ \\
\hline $\begin{array}{l}\text { Thanks to voca- } \\
\text { tional knowledge } \\
\text { acquired in prison }\end{array}$ & $55.5 \%$ & $51.2 \%$ & $49.1 \%$ & $73.0 \%$ \\
\hline \begin{tabular}{l} 
Other \\
\hline
\end{tabular} & $67.9 \%$ & $75.0 \%$ & $64.9 \%$ & $69.9 \%$ \\
\hline
\end{tabular}

It is only in England that inmates have more faith in the efficiency of the resettlement agencies. This confirms my own observations that the English services are more active in helping inmates reintegrate into the labour market, pooling both public resources and those of private associations and trusts. Since 2003/2004 a new key performance indicator measures the number of actual placements and imposes an obligation to show results. ${ }^{248}$ The number of inmates, who base their hopes for their future professional life on qualifications and skills acquired in

248 KPI 9: Resettlement. Target for 2005-2006: To ensure that 34,890 prisoners had an employment, training or education place on release. This target was exceeded by 4,106 places. Source: Leech (2006), p. 696. 
prison, is also substantially higher in England, perhaps because they can combine work with key skills and vocational training.

Not all respondents saw their future in such a positive light. 37.3 per cent estimated their chances on the labour market as bleak because of employer prejudice (80.3 per cent), the difficult general situation on the job market (67.1 per cent), and the lack of support and resources upon release (64 per cent). The fear about employer prejudice is particularly strong in England (93.7 per cent), whereas the unfavourable economic situation worries most French prisoners (88.9 prisoners). Lack of help at the time of release is seen as the major obstacle by German inmates (71.5 per cent). Under the "other" heading, one's age at the time of release is quoted by $43.5 \%$ as the biggest handicap, followed by lack of preparation inside (22.4 per cent), and the negative impact of prolonged imprisonment on personal qualities and traits that render a person attractive to employers (12.9 per cent).

The most pertinent analysis of what makes ex-prisoners employable (or not) comes from a French inmate, who is working on a $\mathrm{PhD}$ in sociology. I quote it in full:

We may ask ourselves what criteria determine that one individual is more or less employable than another. I exclude from my list inherent qualities such as particular competencies required or specific selection criteria such as age, diplomas, former experience etc. [...] I also exclude all jobs obtained via recruiting agencies; ex-convicts have no chance of seeing their application short-listed. Practically all recruiting agencies have at their disposal means to obtain information about the criminal record of applicants and none will take the risk of suggesting to an employer the application of a person with such a record. [...] I exclude for the same reason all jobs that have to do with public administrations or major industrial groups, as they systematically demand to see copies of criminal records, but I retain criteria such as physical appearance (in body as well as in style of clothing), performance during job interview and self-confidence and independence. Those criteria are applied according to the following characteristics: physical, economic, psychological and situational.

Physical characteristics: As is commonly said: "You have to look the part". Many inmates do not have the means to buy proper clothing for the intended job. After serving a long sentence, they might suffer from poor teeth or failing eyesight without corrective glasses. They may even have a jerky gait after years spent walking in shoes without heels.

Economic characteristics: to be employable you have to have a minimum of assets such as a stable home, means of communication, and means of subsistence until the first wage is earned. It sometimes means having access to a vehicle or to equipment linked to the job (a mate of mine was refused a butcher's job because he did not have his own professional tools).

Psychological characteristics: you have to be able to get through a job interview after a more or less long prison sentence. It means to be able to forget the time 
spent inside in order to show self-confidence in body language and speech. It means being able to speak on free and equal terms; it also means being able to "sell" oneself after time spent being a nobody. Add all the elements that contribute to the feeling of being cut off from outside reality, such as being unable to think in euros, because you have never handled that currency, or hesitating when giving information, or even giving false information in an attempt to hide the time served in prison, etc.

Situational characteristics: These are manifold. First, there is the personal situation, such as being alone at a certain age (without a family, no partner or spouse, without children) and totally cut off from what occurred while you were inside (cost of living, awareness of going rates in the profession). You are also put in a situation where you have to make up a past in order to hide your time in prison. If you choose to tell people about your criminal record, you have to be able to handle all the questions: the reasons for your imprisonment, your life behind the walls, etc. And finally, when you apply for a job on parole, it is impossible for you to quote a definite date for your release or to be even sure of such a release. What employer can afford to hire an inmate without knowing if and when that person will be granted parole? That is actually the reason why the majority of job offers made in such cases are made out of compliance but do not lead to an actual hiring.

I dare not broach the subject of employability as far as the contribution made by the Prison Service is concerned because it is virtually nil. Nothing is done in practice to help a prisoner find a job. The legal provisions that are set up (exceptional leave granted for such cases) are so cumbersome and subject to so many arbitrary decisions that they are void. I shall not mention the judges who have a very "personal" set of values regarding the employability of a prisoner and sometimes reject real job opportunities for well-sounding but phony job offers. As for resettlement agencies, we have reached [in France] an abyss of absurdity and of sheer incompetence since social services on the inside merged with the resettlement agencies outside. And yet, in spite of all this and precisely because so much is left undone, the field is wide open to improvements, and one should not give up hope.

Faced with such difficulties, it is not surprising that the number of exprisoners who find a stable job is very low. But if the chances of inmates who have a job in prison are slim, what about those who are faced with unemployment during their sentence?

\section{Prison labour as seen through the eyes of the unemployed}

The great diversity of situations that emerged from the interviews with unemployed inmates does not allow for easy generalisations about their views on prison labour and their own professional outlook. Some inmates had worked all their lives. For them, the fact of finding themselves unemployed in prison was an additional and major hardship. Any job, even the most menial, was a ray of hope in the 
desert of their prison life. Others admitted frankly that they had no interest in working because their access to outside cash was sufficient to cover their needs, and that they knew better ways of spending their time than wasting their efforts on a boring job. Between these two extremes we came across a variety of cases, most with serious problems of employability. Some inmates had physical disabilities such as poor eyesight or locomotive problems; the majority struggled with psychological handicaps. All had at some time worked, but had lost their job because of incompetence or because they could not get along with their supervisors or teammates. Many felt isolated and abandoned. The most pathetic case was that of an English prisoner sentenced to "real" life. He had been fired three times from his job because he could not or would not submit to some detail of the workshop rules (for instance not to bring drinks into the work area). Since the last incident, three years earlier, he had spent most of his days alone in his cell, and distrusted his fellow inmates as well as the officers. His only solace was gardening. He showed me a small flowerpot that he had filled with scraps of paper and some dust scooped up in the prison yard in order to plant some seeds in his cell. It speaks highly for the human qualities of the industrial manager who, after having checked his story, personally supplied him with the necessary material to create a small indoor garden.

In France, where inmates are no longer compelled to work, some prisoners refuse job placements out of principle. Convinced that the governor and his staff do not care about them but only use their labour to better the prison budget, they reject all cooperation with the administration. One French inmate, who is serving a life sentence and has refused to work for the past four years, made this bitter comment:

A prisoner without a job is practically refused everything and anything (pardons, temporary leave, parole, etc.). Work has become a means to blackmail the prisoners. Work - according to the official slogans - is the most excellent "means of rehabilitation". Yet the fact is that most ex-convicts who re-offend were model workers. Loads of other prisoners who have worked little or not at all in prison, and who had to serve practically their whole sentence, given that the blackmail system in place denied them everything, those are the types of blokes that never come back to prison.

Another thing. Take a guy who works (in prison) and uses all his disposable money on purchasing drugs or (and) pornographic material or (and) other items: in what way is his work a "token of good will showing his desire to be reintegrated"? But a guy who has no job but learns, for instance, all by himself in his "cage" another language (or learns computer science or the like), that guy shows no good will to get reintegrated according to the arbitrary and false criteria applied here. He is therefore not entitled to anything (no pardon, no release on parole, no temporary leave) as opposed to the pornographer, the drug addict and the like. And yet which of those two blokes is more likely to manage a successful "return to society"?

You can see that in the end nobody cares a hoot whether or not a prisoner makes an effort to be "reintegrated". What interests the administration above anything else is that people in prisons work in order to bring cash to the prisons. For ex- 
ample, in a prison with 200 inmates, if 140 have productive jobs, they bring in 45 euros worth of "maintenance costs" per month. That is $300 \times 45=13,500$ euros per month and 162,000 euros per year.

One kilo of oranges costs 2 euros here, an $8 \mathrm{~cm}$ round jam tart costs 1.80 ! One kilo of sugar 1.20! And so on and so forth! It is therefore easy to understand that, especially for long sentences, everybody higher up wants to maintain the blackmail system imposed on the blokes in prison, those good old cows to be milked! Let me give you an example: Q., a lifer, could figure out (from the notebooks he keeps) that in 16 years inside, he spent about 22,400 euros in canteen costs (foodstuff, clothes, magazines etc.). It is therefore quite easy to understand that from the judges down, everybody is very much in favour of long sentences. A prisoner brings money to prisons and to shopkeepers in the neighbourhood (which are so hostile to the prisoners). Money does not stink, even if it comes from somebody like Patrick Henri.

These views do not necessarily mirror prison life, but they do show the bitterness of prisoners who do not feel they are treated with fairness and justice. The fate of inmates who, for one reason or another, rate low on the employability scale is certainly not enviable: they have no spending money, nothing to occupy their time with, and they count for little in the eyes of both the administration and the other inmates. If the professional outlook is bleak for those who have held regular jobs in prison, it is almost hopeless for those who have spent long periods in idleness.

\section{Reform Proposals}

Employees of a firm are often in a vantage position to assess the weak spots and the untapped potential of the production process. This also holds true for inmates working in industries or in the domestic sector. How would they improve work in prison if they had the opportunity to do so? Their suggestions appear below.

Table 26: Inmates' suggestions as how to improve prison labour

\begin{tabular}{|l|ll|ll|l|}
\hline Suggestions & France & Germany & England \\
\hline $\begin{array}{l}\text { Concerning remunera- } \\
\text { tion: Increase, different } \\
\text { distribution }\end{array}$ & $56.1 \%$ & (1) & $50.6 \%$ & (1) & $73.1 \% \quad$ (1) \\
\hline $\begin{array}{l}\text { Employment law: social } \\
\text { protection, paid holi- } \\
\text { days, benefits in case of } \\
\text { accident at work, em- }\end{array}$ & $37.9 \%$ & $\mathbf{( 3 )}$ & $32.6 \%$ & $\mathbf{( 2 )}$ & $7.6 \%$ \\
\hline
\end{tabular}




\begin{tabular}{|l|l|l|l|}
\hline $\begin{array}{l}\text { ployment guarantee, } \\
\text { contract of employment }\end{array}$ & & & \\
\hline $\begin{array}{l}\text { Organisation : modern } \\
\text { methods, less bureauc- } \\
\text { racy, longer work days, } \\
\text { better equipment }\end{array}$ & $39.4 \% \quad$ (2) & $22.6 \%$ & $20 \%$ \\
\hline $\begin{array}{l}\text { Quality and choice of } \\
\text { work: modern jobs, } \\
\text { adapted to abilities }\end{array}$ & $30.3 \%$ & $26.8 \% \quad$ (3) & $55.9 \% \quad$ (2) \\
\hline $\begin{array}{l}\text { Training: choice, qual- } \\
\text { ity, market orientation }\end{array}$ & $28.8 \%$ & $22.6 \% \quad 0.3 \%$ & (3) \\
\hline
\end{tabular}

The figures in bold indicate the rank.

\section{A. Suggestion $n^{\circ} 1$ : changes in pay structure}

Were the inmates given the opportunity to propose changes, they would first modify the pay structure to bring it more in line with outside rates, in order to have more disposable funds, to help their families, reduce the debt load and save up enough to get through the first few weeks outside. Given that the level of prison wages is lowest in England, we understand why this concern is most strongly voiced by English inmates. As they see it, if the Prison Service continues to pay ridiculously low wages, it can only expect an unmotivated workforce and thus a lower level of productivity.

French and German inmates are equally critical of the current salary level. A German inmate expressed himself in the following terms: "It is understandable that you cannot find in prison the same range of jobs as outside. We are happy enough to be able to work, but a decent wage is still important. After twelve and a half years inside I shall be released with 613 euros $^{249}$ in my pocket. No home, no furniture, no clothes, no job! The prospect is not exactly rosy and I am worried stiff."

249 This figure seems at first glance impossibly low, but is explained by the fact that all savings above a certain minimum are open to seizure by creditors. 


\section{B. Other proposals}

The next change for French prisoners would concern the organisation of workshops, which they consider cumbersome and ill adapted to modern conditions. They would introduce a continuous workday and shift-work in order to hire more workers, and they would insist on regular staff training. They would be more severe when faced with "a botched job and people lazing about," and they would also take better care of materials and equipment. But above all they would change the hierarchical structure in the workshop between manager and workers, give more responsibilities to inmates, and rely more on mutual trust. This would motivate them to give their best.

One of the major concerns of English inmates is the obsession with security checks that curtail an already short working day and discourage outside firms from transferring part of their production to prisons. The frequent controls are also resented as humiliating and counterproductive. Many inmates would gladly work longer hours, some even evenings or Saturdays. They criticise the lack of rigour in prison run workshops where managers are more concerned with keeping inmates occupied than with running a competitive business. Their comments on the competence and attitudes of their instructors are sometimes harsh. One inmate expostulates: "Deliver us from this dead weight, these lazy officers who do nothing but shout at us." Another voices the same sentiment in more moderate tones: "With competent and eager staff, our workshops would be just as profitable as those outside. There are enough inmates willing and able to work." Others harbour no illusions as to the professional qualities of their colleagues and want a better selection of candidates. They would like inmates to be subdivided into three groups: those who work well without supervision; those who are willing, but need guidance, and those who do not want to work. Productivity would go up and costs could be cut, as the most independent group would not need a foreman.

The German work organisation, despite its good reputation abroad, is not praised by its workers, who are even more critical than their French and English counterparts about the lack of managerial skills shown by their superiors, and the poor quality of "pre-war" equipment. They are also frustrated by the way jobs are assigned without taking into account the talents and inclinations of the individuals. Inmates have no means of finding out when a job is opening up in another workshop that would suit them better. They recommend that all open positions should be displayed on a central board in order to give the workers the possibility to apply for a transfer. They suspect that these transfers are too often barred because workshops do not want to lose an experienced worker. But what seemed to them even more urgent than the reorganisation of work is the reform of their legal status, in particular the extension of social benefits. Every third inmate pleaded for registration into the retirement scheme. Many have expressed their anxiety at being released from prison without work prospects because they are too old, and without 
the hope of getting a pension, in spite of many years worked inside a prison. This is how one inmate summarised their plight: "We need above all else better social protection! Rights to a pension scheme, to medical care, the right to be protected from legal seizures, a chance to build a small release fund to start a new life. Most of my colleagues have seen their existence (family, housing, etc) destroyed by Justice!"

French workers want better protections against lay-offs and compensation payments for the days lost due to accident at work or illness. From their point of view, the best solution would be to sign a real work contract that would entitle them to paid holidays and in-house training. They also criticise the lax way hygiene and safety rules are complied with. This last point is also frequently raised by English inmates, even if they seem generally less preoccupied with workers' rights than French and German inmates. This has perhaps to do with lesser expectations in the English context where even free workers enjoy a lower level of protection compared to France or Germany. Nonetheless, several English inmates have specifically mentioned access to pension schemes, paid holidays and better protections against dismissal.

Many prisoners in England (56 per cent) criticise the quality and choice of jobs on offer. They complain about monotonous jobs that no longer exist outside and want them replace by more up to date activities in the field of computers or in the building and service trades. They would introduce a greater variety of workshops, adapted to individual skills and inclinations. Similar proposals were made by nearly a third of French and a quarter of German inmates. The French want to reduce the number of contracts for low-skilled tasks, in particular if the low added value does not warrant an appropriate wage. There is also concern about the instability of employment caused by the reliance on outside firms that lay off workers without compensation as soon as the business volume slackens. By contrast, German inmates complain that their workshops are too craft-oriented, 250 and that they would wish for more variety to accommodate those who lack manual skills.

Given the shortcomings of French vocational training in prison, I had expected French inmates to complain most about the choice and quality of their apprenticeships. As a matter of fact, it is the English inmates who are the ones to do so although they have the most modern and adapted training schemes that offer recognized vocational qualifications on the job. German inmates want training in other fields than the usual apprenticeships, for instance in computer science, photography or technical areas. They also would wish for a greater commitment to initial training programmes aimed at those who cannot follow the pace of workshops. "It is essential" said one inmate, "to have more preparatory workshops. Six training

250 Craft skills, which were slowly eroded over the past twenty to thirty years, are experiencing a renewal and offer qualified applicants well paid and stable opportunities. It might well be that for once prison workshops are in the forefront of economic trends and that inmates have not yet caught on to this new reality. 
places in the only therapeutic workshop for a total of 700 inmates are but a joke, a token gesture to show that they [the administration] have done something!" Inmates consider the lack of vacancies for sheltered work a serious hindrance to the reintegration of drug addicts and others with psychological problems that do not allow them to hold a regular job.

The desire to be recognised for their work and to be treated with respect and courtesy is more pronounced in Germany and England than in France, and even more so in the high security prisons. Inmates want to be treated as responsible adults who can be trusted and whose initiatives are taken seriously. They are convinced that workshops would benefit from a greater involvement on their part and from more sharing of information about the production process.

Some German workers expressed regrets that the opinion of the workshop managers was rarely sought when it came to deciding on sentence adjustments. In their eyes, master-instructors know inmates better than any other members of staff. They would wish that instructors' tasks included counselling and preparing them for release, because they trust them more than other prison staff.

I conclude on a positive note: eight inmates, 6 German and 2 English declared that the work suited them just fine and that they had nothing to criticise. One German prisoner wrote: "I am lucky to be able to work in a workshop where the boss is first and foremost a human being and not a civil servant acting on behalf of the prison administration. Of course, each workshop has slight problems but if they are not worse than in my own, I can live with them."

This balanced assessment of work shows that inmates are well able to discern the strong and the weak points of workshop management. To grant them a fuller participation in the planning and the organisation of work might thus be good not only for their rehabilitation but also for the productivity of the workshops. 


\section{Part IV: Challenges}

Now that we have looked closely at work and training in nine prisons and listened to what staff and inmates had to say about prison labour, we are ready to deal with the constraints that weigh on prison labour, and examine the various solutions proposed by the three countries

\section{Chapter 1: Obstacles and Constraints}

Expectations are very high. Work is expected to prepare inmates for future employment, provide them with a useful occupation, give some meaning to their sentence and be a source of income for themselves and the administration. All this without creating security problems and without disrupting the prison routine. Some outstanding workshops have managed to reach these objectives, for instance the upholstery workshop in Frankland, the restoration ateliers in Straubing and Kaisheim, and the sound studios in Poissy. But these remain exceptions, and have a small number of carefully selected inmates. When the same expectations are extended to all jobs, difficulties arise. Some are inherent to the prison system and have hampered the development of Prison Industries since the beginning. Others are linked to changes outside and are at the root of more recent problems. The obstacles are so serious that the Loridant Report uses the term of "work under constraints"251 and the German economist Axel Neu speaks of "built in productivity barriers."252 I have divided them into three groups: material and structural constraints; difficulties due to external economic transformations, and barriers linked to human factors.

251 Rapport Loridant, (2002), p.46

252 Neu (1997), in: Hammerschick/Pilgram (eds.), p.99. 


\section{Material and Structural Constraints}

\section{A. Unsuitable sites, premises and equipment}

\section{Ill-adapted locations and premises}

Prisons used to be in towns or in the suburbs. Now they are more likely to be built far away from urban centres, in the few communities that are still willing to accept their construction. This is unfortunate for staff and inmates who are isolated, but also for work, which becomes more difficult and costly to organise. The three research prisons located in less industrialised areas all had below average employment rates. ${ }^{253}$ Only one out of the nine research prisons was within easy reach by public transport. Four were located in old forts or reconverted convents. One has just celebrated its hundredth anniversary, and only four were of recent construction, three of which in England. Such statistics are not exceptional. None of the six French maisons centrales (high security prisons) are less than one hundred years old, and most were built well before the French Revolution. The same is true for many of the detention centres. The situation is analogous in Germany. England began building new prisons as early as the 1970 s, but even so the number of older prisons is still considerable. Most of the old buildings are not adapted for industrial work because the available space is too limited to set up modern workshops. To give an example: in France, a prison workplace is given at best $15 \mathrm{~m}^{2}$ of space for work, storage and access. On the outside, one would find $100 \mathrm{~m}^{2}$ or even $350 \mathrm{~m}^{2}$ for highly industrialised activities. ${ }^{254}$ Even in England, most of the workshops set up for semi-skilled production are too small to be profitable. ${ }^{255}$ This type of production is only economically interesting if it is conducted on a large scale and has a long run. Small workshops working on short run production lines - the norm inside prison - need a competent and specialised labour force capable of producing items with a high added value in order to be profitable. Unfortunately, most prison workshops produce small amounts of products with very small added value and short production runs.

Many workshops are not only too small but they are badly located on a first or second floor without a lift to transport the material, poorly ventilated, inadequately lighted and short on storage areas. Older prisons often lack easy access for delivery trucks. The holding areas are too low to accommodate articulated lorries, and there is usually only one gate for vehicles, which is closed after workshop hours. In order

253 The average employment and training rate in the nine research prisons in 2002 was 59.9\%. Montmédy: $46 \%$ (but above average in 2007, with a rate of $65.8 \%$ ); Kaisheim: $54 \%$ (down to $50.1 \%$ in 2007); Frankland: $59.4 \%$ (down to $54.4 \%$ in 2007 )

254 Rapport Loridant (2002), p. 43.

255 Legge (1974), British Journal of Criminology, p. 9. 
to overcome these restrictions, establishments may be compelled to rent storage space outside the prison compound.

\section{Second-rate equipment}

The low productivity rate of prison workshops can often be blamed on outdated and second-rate equipment. Workshop managers do apply for more sophisticated, work-saving machinery, but they are faced with three difficulties: funding, the lack of inmates competent to operate such equipment, and the need to keep employment figures high. In England and Germany, textile workshops still rely on elementary sewing machines because, in this way, more inmates can be occupied with simple tasks. Even in printing workshops, where new methods require heavier investment, priority is given to job creation. There is also the problem of amortisation, for if outside firms can run their machines on a 24 -hour basis, prison workshops cannot exceed six to seven hours.

\section{B. Constraints linked to the prison structure}

\section{Rising prison population - rising security}

In the last twenty years, prisons have seen an unprecedented population increase. $^{256}$ This has had several negative consequences on prison labour. The creation of new posts has not kept up with the demand. Governors everywhere are under strong pressure to ensure secure containment of the prisoners in their charge, and devote much of their energy and budget to security-related issues. The price to pay is high, first of all in sheer waste of time. According to a study by the Hessian Ministry of Justice, actual working hours in the prison workshops (between 30 and 32 hours per week) are below the official 38.5 hours because of security related issues: roll calls, tool counting, and searches. If an inmate, whether at work or not, is momentarily untraceable, the whole production comes to a stop. If a tool gets misplaced, the activity is suspended. Considerations linked to security exclude the allocation of qualified workers to certain workshops that are located near an outside wall, or to the kitchens where access to knives could be a risk. These measures bear heavily on the decision taken by firms to set up a prison workshop. Many contractors have decided against such a commitment when they realised the types of obstacles they would have to overcome before even setting foot in the workshop: re-

256 The prison population in France has risen from 53,758 inmates in 1994 to 63,598 in June 2007 (+18.3\%); in England it has gone from 49,392 inmates in 1994 to 80,450 $(+63 \%)$ in 2007 . Only Germany has managed to keep its population relatively stable around 79,000 inmates. 
stricted delivery hours, unpredictable delays at entry points, searches of the lorries, and occasionally even of the drivers or foremen.

The tougher stance on crime results in our prisons being filled with a growing number of small delinquents, unused to regular work, who lower the quality of the labour force. The pressure to keep offenders locked up for most of their sentence has also led to a decrease in outside work placements. Even domestic jobs outside the immediate confines of the prison, such as jobs in the staff kitchen, in the gardens or on the farm, have suffered.

\section{Prison routine}

The higher the level of security in a prison, the more regulated is the daily routine. Workshop hours may not interfere with this schedule. Overtime or flexible hours that would create additional movement of inmates are a thing of the past. Shop hours may also not interfere with the traditional break-times of prison officers. In most English prisons, workshops are compelled to break for lunch already at about 11.30 a.m. so that meals can be distributed before the staff break. As workshops in England do not open at 6.45 a.m. as in Germany but rather at 8.30 a.m. or 9.00 a.m., the workers have just settled into their work rhythm when it is already time to tidy everything away and be checked again.

\section{Turnover of manpower}

The efficient organisation of production is also hampered by the frequent turnover of workers, who are taken off the job, transferred or released. Such constant change damages the work climate, makes it more difficult to maintain a stable competence basis, and leads to the wasting of a lot of time in training new workers. $\mathrm{Neu}^{257}$ notes that, in statistical terms, the whole prison population is renewed every year. The problem is more acute in local prisons than in long-term establishments but, even there, the turnover rate would create great difficulties for any external firm.

\section{Conflicting goals}

30 years ago, Legge pointed out that the use of prison labour for conflicting functions was one of the main reasons for poor workshop performance. This has not changed. I have mentioned the incompatibility between economic goals and the rehabilitation of inmates who are unable to work at a regular industrial pace. I also touched upon the tension between wanting to occupy a maximum number of in-

${ }^{257} \mathrm{Neu}$ (1997), in: Hammerschick/Pilgram (eds.), p. 100. 
mates and purchasing labour saving machinery. Striking a balance has become even more difficult since security considerations have acquired their present dominant position.

\section{Constraints Linked to External Economic Transformations}

Lack of funding for improving the premises, modernising the equipment, hiring sufficient staff, and experimenting with new production is a major problem of prison work. The standard excuse that the state of the economy does not permit any budget increase does not stand up to scrutiny: prison work has rarely benefited from generous funding even in times of economic prosperity. In addition to this basic difficulty, prison labour has also to contend with new challenges in the form of economic changes on a global level. This has a profound impact on the number of jobs and on the role of work.

\section{A. Economic transformations have left Prison Industries behind}

Let us briefly summarize the main developments: The number of industrial and crafts jobs has decreased, whereas those in the tertiary sector have increased. Emerging countries produce now what was traditionally manufactured in prisons (textiles, engineering). Simple assembly jobs, a mainstay of prison labour, have been mechanized. Governors and managers are helpless because they cannot match the rise in the service sector where most jobs require a certain freedom of movement (transport, hotel or restaurant sectors) and access to communication means (telephone, Internet). They see no viable alternatives that would allow them to close down non-productive workshops, and they find it difficult to attract contractors when salaries in Eastern Europe are lower than in French and German prisons. Workshop managers also have to contend with a new "just in time" style of production. Long-term planning and stock building are a thing of the past. Nowadays, production starts when the order arrives. It must meet the specifications of the client, and delays have to be avoided at all cost. This is a formidable challenge for an institution as inflexible as prison and with priorities other than economic efficiency.

\section{B. Competition for shrinking orders}

Faced with the task of finding cost effective occupations for a largely unskilled work force, prison administrations have often opted for labour intensive sectors that need little training and a minimum of material investment. Such activities have been directly hit by globalisation, and companies that have traditionally contracted out part of their production to prisons are shifting these jobs to Eastern European or 
Asian countries, where they get a better return for their investments. Competition has thus become fiercer for the remaining contracts, both between prison establishments and protected workshops. Workshops for the handicapped may have a labour force that is slow, but it is stable and motivated. Hiring the disabled gives the companies tax concessions they do not get when employing inmates. At the same time they avoid disadvantages associated with prisons: cumbersome security controls, risk of riots or of finding the access blocked by disgruntled prison officers. It follows that firms, especially in France, show a preference for such centres. One could of course argue that it is no great loss if jobs that can be performed by the mentally handicapped disappear from prisons.

\section{Work is suffering from a loss of status}

We need only to read the titles of popular books, such as The End of Work ${ }^{258}$ or Work, a Value Threatened with Extinction ${ }^{259}$ to become aware of a certain malaise. The predictions of the authors may be exaggerated. Work is not going to disappear nor will it lose its role in society, but we are no longer as sure as we used to be of the central role of work. The endemic unemployment rate of close to 9 per cent in France and Germany has not been without affect on prison labour: it has reduced the value of the "resource inmate" and given rise to resignation. What is the point of training people who are no longer needed on the labour market? Some authors like Harald Preusker even think that it might be better to prepare inmates for a life on social assistance rather than to perpetuate the illusion that they will find work when they get out. ${ }^{260}$ Given the dismal employment statistics of ex-inmates, Preusker's solution is not as provocative as it may seem at first glance, but accepting it means defeat. It is necessary for the morale of the workers and for the future of prison labour to keep up the hope that jobs will again become available, and that work and training do play a part in increasing the employability of inmates.

\section{The human element}

Productivity in prison, as elsewhere, depends to a large extent on the quality of the people working. Free enterprise can, to some extent, reduce the impact of the human factor by mechanizing production, but this option is limited in prison. A firm can also choose its employees and fire them if they do not give full satisfaction; a prison must make do with the labour force it is allocated and, in many cases, with local staff.

\footnotetext{
258 Rifkin (1995).

259 Méda (1995).

260 Preusker (1988), ZfStrVo, Nº 2, p. 92-95.
} 


\section{A largely unskilled labour force}

The report of the English Social Exclusion Unit, the French INSEE survey, and German studies quoted in the first part of our research ${ }^{261}$ confirm without exception that the general level of education and vocational training of many inmates is well below that of the general population. Many have had an unstable professional career. A disproportionate number have mental disorders or suffer from drugrelated problems. 13.6 per cent of inmates in England, 21.1 per cent in France and 35 per cent in Bavaria are foreigners, ${ }^{262}$ who often do not master the language of the host country well. It follows that standard prison workshops cannot achieve the same level of efficiency as the few that are allowed to choose the best candidates. Administrations are thus faced with the dilemma of either allowing two classes of workshops or of lowering all tasks to the level of the average inmate and thus losing interesting and profitable contracts. England tries to avoid this problem by encouraging less qualified workers by various means (extra privileges, paid training and education during working hours) to improve their basic skills and professional abilities. It may be too early to say if this initiative will work, but it seems worth trying.

\section{B. Lack of motivation}

Prison administrations have few means to motivate their working inmates. The award system is so different from the one practised outside that Legge rightly describes it as an inverted structure. ${ }^{263}$ Of the two forms of positive motivation available in prison: reduction of the time spent inside and better conditions, neither works well. In the first case, there is no direct link between effort at work and early release, as other criteria, in particular the risk of recidivism, are given greater priority. The second form (wages, status, or job satisfaction) does not have the same weight within prison as in free society. Remuneration, especially in England, is too low to encourage greater efforts. Intangible rewards, such as job satisfaction and prestige, have lost much of their attractiveness. I have only met a handful of inmates who said they were happy and satisfied in their jobs. Most tasks do not offer the necessary responsibility, variety, or professional interest. These deficits are compounded by the inmate subculture, for compliments expressed by a foreman for

261 Social Exclusion Unit (July 2002); Insee ( Jan. 2002); Dünkel in: Dünkel/van Zyl Smit (eds.) (1998). See above, part I, chap. 1, I A 2.

262 Prison Statistics England and Wales (2007); Administration pénitentiaire, (2005); Bayerisches Staatsministerium der Justiz, (2002).

263 Legge (1978), British Journal of Criminology, p. $17 \mathrm{f}$. 
a job well done may decrease the status of a worker among his colleagues, and a promotion may be interpreted as a reward for "ratting".

In the repressive atmosphere of a prison, one might expect that the fear of sanctions might motivate workers to perform well. This is however an illusion, as workshop discipline is less strict than in free enterprise. Because the labour force is more difficult to handle and more prone to explode, it is sometimes advisable to close an eye to irregularities rather than provoke an angry reaction from the person at fault.

\section{Management, staff, trade unions}

It would not be fair to dwell only on the shortcomings of the inmate workforce. Management and supervising personnel also bear some of the responsibility for poor economic results. The Loridant Report blames the governors for their "pragmatism", i.e., for the ease with which they accept less than satisfactory arrangements. ${ }^{264}$ French prison directors often delegate the responsibility for work and training to junior assistants, who lack experience and are at a disadvantage when dealing with outside contractors. This is less the case in Germany or England where specialised teams look after the commercial management of workshops.

Managers, foremen, instructors and officers play a decisive role in ensuring the smooth running of workshops and domestic services. The instructors spend more time with the inmates and know them better than other members of the prison staff. They are mainly responsible for creating a good working atmosphere and motivating the workers with a personal touch. I mentioned the Featherstone textile workshop where many workers admitted that they made an effort mainly to please their female instructors. Unfortunately, the positive contribution from staff is often under-used. Frances Simon, when interviewing instructors in prisons, reports that many wished to be more actively involved in the training of the inmates. They regretted that production pressures did not leave them enough time to deal with the personal problems of their workers. They were also upset by the refusal of the other Prison Services to keep them informed on disciplinary actions or on imminent transfers. Once an inmate leaves the workshop, there is no feedback to check if his work experience has helped to enhance his professional competence or relational skills. ${ }^{265}$ French and German instructors interviewed during our research voiced exactly the same complaints.

The Loridant Report deplores the lack of commercial training of the workshop staff and their allocation to posts that are beyond their competence.

264 Rapport Loridant (2002), p. 49.

265 Simon (1999), p. 197-199. 
At the head of workshops, one can find members of staff, who are very competent but have the greatest difficulties trying to combine widely different tasks. These people are expected to fulfil a supervisory and managerial role, to be technically competent in the activity pertaining to the workshop and, finally, to be in charge of its financial and commercial management [...] Generally, there is a lack of training in the industrial and commercial management of a specific workshop. In addition to the multiplication of roles described above, we find that some workshop managers are in fact prison officers, who sometimes are obliged to wear their uniforms, which does not help to impose their authority in technical or commercial matters. 266

The lack of technical know-how and interest in the economic aspect of production is also frequently criticised in the other two countries. Insufficient recruiting further jeopardises the good organisation of workshops. Overworked staff has no time for individual supervision or for a more efficient reorganisation of work.

To summarize: The various constraints and difficulties evoked do not enable workshops to approach the productivity levels achieved outside. However, the considerable span observed between the countries, i.e., 15 to 20 per cent of the external productivity rate for Germany, ${ }^{267} 20$ to 40 per cent in England ${ }^{268}$ and 40 to 50 per cent in France, ${ }^{269}$ is puzzling since I could observe no noticeable national differences between the quality of inmate workers, instructors or equipment. If anything, the German workshops were run more efficiently than in the other two countries. As no indications were given as to how the productivity figures were arrived at, it is possible that the three countries used different criteria for their calculations.

\section{Chapter 2: Difficult Reforms}

Prison reforms have long been called for, and many excellent proposals have been formulated, yet there has been little change for the better. We are still faced with the difficulty of creating enough work, pay rates remain below minimum standards, and employment rights have yet to penetrate the prison wall. In this concluding chapter, I briefly summarize the most recent reform proposals and try to explain why the implementation of so many proposals has fallen short of expectations.

266 Rapport Loridant (2002), p. 74.

267 Dünkel (1999), in: Van Zyl Smit/Dünkel (eds.), p. 87; Fulton/Smartt (1996), Prison Service Journal, p. 5.

268 Smartt/Vagg (1998), Prison Service Journal, p. 8.

269 Talandier (1987), p. 65. 


\section{Recent reform proposal}

I begin with the French proposals, as they are more numerous than those in the other two countries.

\section{A. French initiatives}

Media attention on prisons has been high over the past years. The publication, in early 2000, of an account on the prison conditions in a major local prison in Paris by its chief medical officer sent shockwaves through France. ${ }^{270}$ As a result, two parliamentary study commissions were mandated a few months later to report on the state of French prisons. Not that the many shortcomings of the French prison system had been unknown before, but the publication of Dr. Vasseur's book and the publicity it was given by the media required more drastic government action. Before focusing on the ensuing reports, let us look at earlier initiatives that go back to 1987.

\section{The projet de loi relatif au service public pénitentiaire (Bill pertaining to the public penitentiary service), adopted on $11^{\text {th }}$ June 1987}

This law is remarkable for two aspects: it introduced prisons under mixed management (private and public), and it removed the mandatory nature of prison labour. The introduction of semi-private prisons, delegating the construction and several management functions, among others prison labour, to the private sector, met strong opposition and is controversial to the present day. In contrast, the decision to remove the mandatory nature of work was adopted without discussion, despite its almost revolutionary character. France is the only country in Europe to have taken such a step. ${ }^{271}$ Members of Parliament probably thought they were simply rubberstamping a fait accompli, as the shortage of jobs had already rendered mandatory work illusory.

\section{The report by the Social and Economic Council "Travail et prison", submitted by Jean Talandier in December 1987}

This outstanding report on prison labour already contains all the elements required for fundamental reform. It presents a clear analysis of the difficulties: our collective memory retaining work as part of punishment, the absence of a proper legal framework, the derisory level of remuneration, an organisation that does not

270 Vasseur (2000).

271 In Spain and Denmark work itself is not mandatory but both countries have maintained the mandatory nature of an activity, be it education, training or work (Rapport Loridant (2002), p. 141). 
match outside standards because of arbitrary constraints, prison overcrowding, the heterogeneous and under-qualified labour force and, finally, an insufficient budget. The report stresses that the Prison Service should be compelled to take "all measures to ensure that a professional activity is offered to all inmates who wish to have one." Such an obligation implies, first, that enough work places are provided and, second, that the tasks proposed are proper professional activities and not simply occupational measures. To reach these objectives, the report gives priority to the construction of new, functional workshops over the construction of more prisons. It insists that the different employers be held to their obligation to provide "professional activities" through the revaluation of domestic jobs, an increase of Prison Industries jobs and a stricter selection of outside contractors. Furthermore, greater efforts must be made to develop general education and vocational training.

To promote the professional reintegration of workers, the report suggests that the legal status of working inmates be enhanced by adopting statutory law regulations concerning working conditions, remuneration, rights of expression and access to court. The suggestion to set up a "labour court" inside prisons to be based on the model of the industrial arbitration courts or Conseils de prud'hommes is a particularly original solution. Furthermore, the report recommends that the number of prison staff assigned to workshops and training facilities be increased and that particular attention be paid to their qualifications.

None of these proposals were implemented, but the report stimulated the creation of two three-year plans to improve the quantity and quality of work.

\section{Two three-year plans for the improvement of working conditions and the increase of the number of jobs 272}

Beginning in 1997, the so-called PACTE 1 aimed at increasing by 25 per cent over three years the total earnings and the number of days worked in prison. Those objectives were reached, exceeding all expectations (by 100 per cent in terms of earnings and by 99 per cent for the number of days worked). ${ }^{273}$ This success led the administration to extend the project (PACTE 2, 2000-2003) in order to include quality-related objectives such as providing work for all inmates requesting a job, creating a coherent link between work and training, and narrowing the gap between prison regulations and employment law. Unfortunately, the implementation of PACTE 2 was hampered from the outset by events that were outside the control of the Prison Service. The accelerated outsourcing of production to emerging countries led to a sharp decrease in the number of firms seeking to set up workshops in

272 (Plan d'Action pour la Croissance du Travail et de l'Emploi et Plan d'Amélioration des Conditions de Travail et d'Emploi : PACTES 1 and 2).

273 Direction de l'administration pénitentiaire (2002), p. 8. 
prison. At the same time, prisons had to cope with an unprecedented increase in the prison population: from 48,594 inmates on January $1^{\text {st }} 2002$ to more than 64,451 on $1^{\text {st }}$ of June 2004. It was simply not possible to create enough jobs for the newcomers when the offer was insufficient before. The prison budget was, and still is, used up by the sheer cost of maintaining and supervising a growing inmate population, and there are no reserves to increase the number of skilled work places. Slight progress was made in improving the link between work and training, and some prisons have introduced a form of work contract that specifies the working conditions and mutual obligations, which is however not legally binding.

\section{Reforms proposed by the two parliamentary commissions of 2000}

The two commissions set up by Parliament and the Senate after the publication of Dr. Vasseur's Médecin-chef à la prison de la Santé were mandated to give a general overview of the state of French prisons. Prison labour was thus only a minor aspect of the whole, and the recommendations on our subject less detailed. The Senate commission advocated higher pay rates for domestic duties and the abolition of deductions for maintenance. It also recommended that greater weight be given to work performance in parole decisions and for sentence remissions. ${ }^{274}$ The commission of the National Assembly urged an increase of qualified and qualifying activities and full compliance with employment law, because "all things considered, the lack of respect for employment rights ruins the notion of prison work as an instrument of rehabilitation."275 According to the members of Parliament, "introducing employment rights would become unavoidable, and legal obstacles had to be set aside." 276 One can only hope that this prediction comes true, but it will not be in the near future. The bill for a prison law, drafted after the publication of the parliamentary reports and containing provisions for a contract of employment, never reached the voting stage and was shelved after a change of government.

To the best of my knowledge, the only concrete reform resulting from the two reports concerns the domestic sector. In 2002, Prison Service headquarters published new guidelines advocating more supervision and tutoring of inmates employed in domestic tasks, the introduction of alternative periods of work and training, and an increase in remuneration.

274 Senat, Rapport du (2000), p.198 f.

275 Assemblée Nationale, Rapport (2000), p. 197.

276 Ibid. p. 198. 


\section{The Loridant Report 277}

The Report of the Senate commission headed by Paul Loridant is the most relevant recent document on prison labour. The commission was originally mandated to audit the budget of the RIEP (régie industrielle des emplois penitentiaries, the French equivalent of English Prison Industries or the German Eigenbetriebe), but found that this could not be done properly without looking at inmate labour as a whole. The assessment is bleak: Senator Loridant speaks of "the great misery of prison labour." Not only do workshops have to contend with the numerous constraints that we have outlined above 278 but also with those specific to the RIEP: stagnating level of employment, decrease in profits, activities in sectors that no longer correspond to present requirements, misguided orientation toward piece work, and a legal status that makes it impossible for Prison Industries to function as they should. 279

The report contains 62 recommendations, among them: the creation of ten thousand extra jobs, and the transformation of the RIEP into a public entity issued with the task of rehabilitating inmates through work and training. This would allow it to benefit from exemptions concerning employers' contributions and to draw subsidies for each job created. Also recommended is a greater orientation towards sectors of high added value, greater pressure on firms to invest in prison as part of their social obligations, the introduction of an employment contract, and access of workers to unemployment benefits and to compensation payment in cases of work related illness and accidents. Finally, it recommends the abolition of contributions for food and board, improved access to training, and increased outside employment in the final phase of the sentence. ${ }^{280}$

Five years later, only one of the recommendations, the abolition of a compulsory contribution for food and board, has been implemented. But the RIEP has undergone a thorough review, and some of its weaknesses have been corrected.

In the last two years, two more reports 281 and two government research projects ${ }^{282}$ have concerned themselves with prison labour. Their recommendations confirm those of the previous reports, and one can but hope that the cumulative effect of so many excellent proposals will finally produce results.

277 The full title of the report is: Rapport d'information fait au nom de la commission des finances, du contrôle budgétaire et des comptes économiques de la nation sur la mission de contrôle sur le compte de commerce 904-11 de la Régie Industrielle des Etablissements Pénitentiaires (RIEP) de 2002, coordonné par le sénateur Paul Loridant. Sénat, No 330.

278 See above, Part IV, chap.1.

279 Rapport Loridant (2002), p. 51-75.

280 Ibid. p. 78-109.

281 Conseil économique et social (Rapport Décisier) (2005); Cour des comptes (2006).

282 Auvergnon/ Guillemain (2006); Guilbaud (2006). 


\section{B. Reform programmes in Germany and England}

\section{Germany}

In the German federal system, each Bundesland is responsible for its prisons and has its own Prison Service, but the Prison Law (Strafvollzugsgesetz) is federal and applies to the whole of Germany. Reforms can thus affect prison labour in general, or concern only the Land that has introduced them. The most important recent reform at the federal level is the 1998 pay increase imposed by the Federal Constitutional Court. ${ }^{283}$ However, the Court saw no constitutional duty to extend all or even part of social protections to working inmates. ${ }^{284}$

Reforms on the provincial level aim mainly at a more efficient organisation of work, as Prison Services struggle to deal with the extra expenses incurred by the pay increase. In Bavaria and Hesse, the additional cost is quite staggering: $€ 6,132,500$ for Bavaria and $€ 3,201,000$ for Hesse, which is the equivalent of 15.7 per cent and 43.7 per cent of net profits. ${ }^{285} \mathrm{In}$ an attempt to rationalize production, some Länder have opted for a centralised model, the so-called Landesbetrieb vollzugliches Arbeitswesen, i.e., a central and separate organisation of industrial activity with its own budget. Such a structure offers uncontested advantages. For instance, in Lower Saxony the productivity rate of workshops is 40 per cent of that of a comparable external firm, whereas the average rate in German prisons is 15 to 20 per cent. ${ }^{286}$ A more flexible and reactive management, proper commercial bookkeeping and a new entrepreneurial spirit combine to make workshops more profitable. But there are also drawbacks, such as the risk of a conflict of interest between commercial objectives and rehabilitation or security. Bavaria has categorically excluded the Landesbetrie $b^{287}$ model for precisely this reason. It prefers aligning its production to market requirements and setting up a professional commercial strategy. Hesse has chosen a middle way by opting for a central bureau but without creating an independent structure, remaining thus closer to the English model of the ESS or that of the French RIEP.

Another reform project worth pointing out is the so-called Hamburger Modell. Two low-security prisons in Hamburg have been experimenting with "external job placements within prison walls," meaning that in a few selected workshops inmates

\footnotetext{
283 BverfGE 98, 169. Pro memoria: until January 2001, the average wage of working inmates corresponded to 5 per cent of the average wage of all persons covered by the federal pension scheme. This amount percentage was deemed incompatible with the constitutional duty of the State to give each citizen the possibility of rehabilitation. It has since gone up to 9 percent. See above: part II, chap. 2, II A 2 a.

${ }^{284}$ For more detailed information, see above: part II, chap. 2, II B.

$285 \mathrm{Neu}(2001), \mathrm{NK}, \mathrm{n}^{\circ} .2$, p. 24.

286 Lohmann (2002), Arbeit und Arbeitsentlohnung des Strafgefangenen, p. 246.

287 Ibid., p. 249.
} 
can work under a proper contract of employment, with the same rights and obligations as outside workers. The advantages of such a system are obvious: inmates learn to work according to outside standards and are paid accordingly, and the administration can collect from each worker a contribution toward maintenance costs and transfer the cost for employer's contributions and technical supervision to the companies. Unfortunately, the number of inmates able to keep up with outside productivity standards proved to be too small to maintain the project at its initial level. ${ }^{288}$

The same preoccupation with the efficient running of Prison Industries can also be observed in current studies. Authors do not necessarily rank the economic aspect over rehabilitation but they see profitable workshops as the only means to save work from an inevitable decline. Their fears of an increasing marginalisation of industries are well founded. Holland, for example, began in 2004 to shut down all non-profitable workshops in local prisons and to limit work to the domestic sector. ${ }^{289}$ In order to avoid such drastic steps in Germany, the following solutions have been suggested:

1) Increasing the volume of external sales through "social marketing", namely by appealing to the spirit of solidarity in consumers. ${ }^{290}$ Given the failure of this same strategy in England (under the Prindus label), ${ }^{291} \mathrm{I}$ am not very optimistic as to the results. The average consumer wants good value for his money and is not ready to pay a premium or to accept a lesser quality for a cause with as little popular appeal as prisons.

2) "Social sponsoring", i.e., major firms investing in prisons to cover their social obligations. ${ }^{292}$

3) A committee set up by the Ministry for Justice in the Land of Hesse ${ }^{293}$ proposes inter alia: greater flexibility in working hours allowing overtime and, if necessary, weekend work; a greater orientation of certain domestic sectors towards external markets, such as catering, baking or laundry services; a restructuring of traditional training schemes towards shorter, modular models; shift work that would increase the number of work places and would allow for a better use of machinery; closing down non-profitable workshops and replacing them with more promising

288 Hagemann (1995), MschrKrim, Nº6, p. 341-351.

289 Source: Conference given by the Dutch delegation during the European Prison Forum 2004 in Edinburgh.

290 Sigel (1993), ZfStrVo, n 2, p. 85-89.

291 Vagg/Smartt (1999), in: van Zyl Smit/Dünkel (eds.), p. 53.

292 Wrage (1997), NK, n 4, p. 16.

293 Hessisches Ministerium der Justiz, "Erhöhung der Beschäftigungsquote" (2002), p. $18-24$. 
ones; and the right to compete for public procurement markets. Most of these eminently sensible propositions still await implementation.

\section{England}

During the last twenty years, interest in prison labour has been high, and several reform proposals have tried to bring about improvements. The first impetus came from the Woolf Report, asking that priority be given to the rehabilitative aspect of work through higher wages, more interesting jobs and a holistic approach to regime activities that would allow workers to attend classes and improve their vocational qualifications without loss of pay. Two out of theses recommendations have since been implemented: weekly earnings have gone up from $£ 2.80$ to $£ 7.50$. This is an increase of 168 per cent but still not enough to raise English prisoners above their position of "the poor men of Europe."294 By 2001-2002, the holistic vision of regime activities had also gained ground in all three of our research prisons: national vocational qualifications were available in most prison run workshops, and inmates with key skill deficits were given the possibility to attend school for two half days per week without loss of salary.

In the second half of the 1990s two important projects were started: the Workshop expansion scheme, and "enhanced" work. The first aims at higher workshop productivity and full employment, the second makes it possible to pay inmates considerably higher wages if their output warrants it. ${ }^{295}$ Both projects met with partial success, the first, because of a lack of funding, the second, because the regulations of enhanced wages contained in the Prisoners Earnings Act of 1996 have still not been implemented.

In 2002, the year the Loridant Report was published in France, the English Prison Service constituted the Industries Review Team with the mandate to audit the performance of Prison Industries and their management by the Employment and Supply Service (ESS). Given the preponderance of prison run workshops in England (60 per cent) and the control of the ESS over much of the contract work, the team's recommendations ${ }^{296}$ have potentially far reaching consequences. These concern three problem areas: the absence of a clear statement of purpose, the unsatisfactory division of competencies, and several shortcomings regarding organisation, control and communication.

a) The statement of purpose

To narrow down the purpose of prison labour, the report uses two definitions, which are close but not identical.

\footnotetext{
294 Ibid. p. 393.

295 For details, see Vagg/ Smartt (1999), in: van Zyl Smit/Dünkel (eds.), p.63-65.

296 Industries Review Team, Regime Service Group (report by) (2003).
} 
1. Keeping prisoners busy, as an aid to control and providing purposeful employment as cost-effectively as possible; and helping them back into employment after release by giving them skills, accredited training and experience appropriate for the labour market. 297

2. The aim of Prison Industries is to occupy prisoners in out of cell activity and wherever possible to help them gain skills, qualifications and work experience to improve their employment prospects upon release. The management of industries must weigh the true costs and benefits to the organisation and constantly strive for greater efficiency in providing developmental opportunities for prisoners. 298

Both statements stress the occupational role of work, with its double function of providing out of cell activities and facilitating the control of the inmates. Such occupation must be cost-effective and advantageous for the organisation, i.e., for the Prison Service as a whole as well as for Prison Industries. It must also, as much as possible, promote the professional reintegration of the workers by giving them the necessary know-how, training and experience. This is no mean task!

The missions are as numerous as ever but their order of importance is reversed. The occupational role of work and the economic aspect are thrust to the fore, whereas professional reintegration ("wherever possible") takes second place. We may not agree with this ranking but it has the advantage of being honest. If taken off guard, French and German managers would probably formulate the same priorities. Nevertheless, the committee proposes concrete measures to increase the employability of inmates. Assuming that those who have worked little on the outside are most in need of remedial measures, the Team proposes to give them priority in job allocation. This is a daring proposition considering its negative impact on workshop efficiency. It would be out of the question in France where the nonmandatory nature of work excludes the compulsory allocation of those who are not motivated. A similar move also seems improbable in Germany, where production imperatives favour the selection of the most qualified workers. Even in England, I rather doubt that allocation boards would pay it more than lip service.

More promising is a second proposition aimed at encouraging well-qualified and motivated inmates by offering them a "career project" within prison workshops. This would allow them to advance from simpler to more specialized jobs and gain more responsibilities, including administrative ones. The Team also pays attention to inmates with short sentences and speaks in favour of their inclusion into productive activities. This group includes a large number of repeat offenders whose pro-

297 Ibid. p. 16.

298 Ibid. p. 23. 
fessional reintegration could make all the difference between going straight and returning to prison.

\section{b) A clear division of competences}

As we have seen in the case of the French prison of Montmédy, lack of liaison with the establishments can interfere considerably with the support and the directives coming from the central bureau. The Review Team underscores the same problem in England, where it is exacerbated by an uneasy division of competency between headquarters and governors. Following a recommendation of the Woolf Report, more decision-making power was devolved from headquarters to governors in all areas, including work, thereby reducing the action range of the ESS. This led to frictions and uncertainty as to who was responsible for what decision. In order to redress this problem, the report suggests a clear division of competencies and an internal reorganisation of the ESS. The Head of ESS would retain overall responsibility for planning, budget and materials, as well as for job allocation in each sector. Governors would maintain their independence as to how to organise their workshops. As before, they would determine the level of wages for the workers within the limits of their budget, even if the Review Team would rather have handed this power back to the ESS. Area offices as well as two other bodies would be placed between establishments and the ESS. The Advisory Sub-Group, whose membership would comprise members from the private sector, would establish links with the outside world of industry. The Industries Management Board would ensure that workshops function according to commercial standards. This board would not be chaired by the Head of the ESS but by his hierarchic superior, the Head of Regimes, and the members would be drawn from the operational line: an area representative, a governor and a workshop manager; the Head of ESS would only be invited in an advisory capacity. This proposition is of great interest as it gives decision making power to a small group of persons with practical knowledge of the constraints and difficulties work has to contend with. The group would keep in touch with the industrial world, check if the production level agreed upon was maintained, and make sure that the objective of obtaining the best value for money was reached. It would decide on what products to manufacture and which ones to buy on the external market, and would have the final say in case of workshop closure. The Industries Management Board would also make sure that reforms are effectively carried out.

\section{c) Increasing the efficiency of Prison Industries}

The real concern of the report seems to lay with the business side of Prison Industries, a topic that takes up two-thirds of the recommendations. Here are the most important ones: 
1) No head of an enterprise can consider radical changes before having obtained precise data on production figures, cost, etc. The same goes for Prison Industries: reforms are only possible on the basis of accurate data. Each workshop must supply detailed production statistics concerning quality, costs, working hours, number of people occupied, and movement of stock. Such data will help establish forecasts and calculate the budget for the material.

2) Once a decision has been taken to make a product for the internal market, its purchase by the establishments becomes mandatory.

3) Introducing hard charging (selling products at their real cost to establishments) will increase revenue from work and reduce waste of products considered "free".

4) A budget aimed at modernising equipment will only be granted if the investment can translate into a better profit margin. This requires increasing the number of hours worked and upgrading the technical team to avoid faulty installations.

5) Transferring ESS headquarters to Branston in the Midlands, close to the central depot, will enable a better control of the stocks, and rental costs will be considerably lower compared to the present location in a London suburb. Though this transfer will hardly be more popular than the decision to move the French Prison Industries' headquarters to Tulle, it makes sense from an economic and managerial point of view.

If implemented, these reforms would improve the productivity of Prison Industries and make the ESS more efficient and closer to the operational lines, but the reforms may be too narrowly focused. Job creation is given short shrift and there is no particular interest in the qualitative improvement of jobs. Important aspects interfering with workshop efficiency, such as security, are not even mentioned. In many ways, the report can be likened to an audit for a business whose aim is to manufacture cost effective goods for the internal market.

This criticism is not just aimed at the Review Team but applies also to the reforms proposed by Bavaria and Hesse. The French proposals aim higher but, apart from the success of PACTE 1, their implementation is long in coming. None of the three countries has dared to attack the fundamental issues linked to work: the shortage of jobs, the unskilled nature of most tasks, the low pay levels and the absence of employment law. Ministries have at their disposal all the information necessary to transform work into a useful tool for the rehabilitation of prisoners. Several reports offer excellent advice, and yet little has changed. Why? In the next and last section, I shall try to explain this puzzling resistance to reforms. 


\section{Resistance to Reforms}

In Visions of Social Control ${ }^{299}$ the American sociologist Stanley Cohen asks why so many excellent reform projects are shunted into some administrative drawer or diverted from their initial purpose. Three of his answers are particularly relevant in our context. These are organisational convenience, professional interest, and political and economic conditions that run counter to such reforms.

\section{A. Organisational convenience}

One of the reasons why many of the best projects fail is because they are blocked at the organisational level as soon as they approach the implementation stage. Internal constraints as well as outside pressures bearing upon the organisation (lack of funding, a different political agenda) are given as the reason why it is better to do nothing or water down the reforms.

Examples of internal resistances are plentiful. I have already mentioned the lack of concrete measures taken after the reports of the French parliamentary commissions in 2000 and the Loridant Report in 2002. A new status for the RIEP (Prison Industries), more stringent selection of outside contracts, and the introduction of employment contracts were all postponed. Radical change is not welcome. Most prison administrations prefer limiting themselves to small improvements, which will show that "something has been done." The RIEP, for instance, introduced an employment agreement to be signed by inmate workers that specifies working conditions such as working hours, tasks, pace, and remuneration. It may look like a contract but is miles away from a real employment contract for it does not allow for any negotiation and conveys no rights. At most, it specifies the expectations and obligations. Another example of internal resistance concerns the number of hours worked and the hourly remuneration. Both have been increased over the last years, thereby giving the impression of progress. But the number of inmates has grown faster than the number of jobs, ${ }^{300}$ and the hourly remuneration still corresponds to less than half of the minimum wage.

In Germany, the pay increase imposed by the Constitutional Court in $1998^{301}$ provides a striking example of how the best intentions can be derailed. In order to reduce the impact of the additional expense, the Prison Services, including the ones in Bavaria and Hesse, changed the classification of prison jobs. Category 3 tasks (100 per cent on the pay scale) were reclassified as category 2 (84 per cent on the pay scale), and category 2 tasks were given the lower status of simple tasks that

${ }^{299}$ Cohen (1985), Visions of Social Control.

300 According to the Rapport Loridant, at least 10,000 additional jobs would be needed to insure full employment (p.111).

${ }^{301}$ BverfGE 98, 169. See also above, part I, chap.2, II C. 
require no particular skills or training ( 75 per cent on the pays scale). The same strategy was used for bonus payments. These manoeuvres enabled the Länder to recover 40 per cent of the additional cost or, put the other way, inmates were deprived of 40 per cent of their pay increase. ${ }^{302}$ Fortunately there are counterexamples, such as the creation of Landesbetriebe vollzugliches Arbeitswesen in Baden-Wurttemberg or Lower Saxony that have radically transformed the organisation of prison labour. It shows that patience and determination can overcome resistance, when political backing is not wanting.

Organisational convenience, in England as in Germany, leads to the protections of sectors that have no opening on the outside market such as textiles and agriculture. Agriculture employs a small number of inmates and is not a major concern, but the situation is different for textiles. Governors would favour a reduction, HM Chief Inspector of Prisons expressed his concern about the low skill level of the tasks, and inmates work there as a last option. Despite this solid opposition, the Industries Review Team not only proposes to maintain the existing workshops but to increase the number of posts in textiles. ${ }^{303}$ The reason is easy to find: the equipment costs little and is easy to handle even by prisoners with no prior experience. The manufactured goods are useful to clothe an ever-growing prison population. In this case, organisational convenience prevails even over cost efficiency, as the textile sector in English prisons is losing money. ${ }^{304}$

External pressures are as numerous as internal ones. The old French saying Le roi a statué, le roi n'a pas financé (the king has given orders, but the king has not paid) is still as valid as ever. Job creation, workshop renovation, modernising of equipment and staff hiring all depend on the availability of sufficient funding. The best projects, such as the Workshop Expansions Scheme, are doomed to fail if their implementation is conditional on being "resource neutral". Furthermore, security is at a premium. Governors are under strong pressure to put it first and would rather err on the side of too many controls.

\section{B. Professional Interests}

The professional interests of the prison staff can also interfere with the implementation of reforms that would introduce greater efficiency. A well-run workshop requires that workers should leave their posts as little as possible and that appointments with professional services - social workers, guidance counsellors, psychologists and medical services - take place after working hours, i.e., at a time when the fice.

302 Estimate based on the calculations of the Bavarian prison work administration of-

303 Industries Review Team (2003), p. 64.

304 For 2003-2004 the expected deficit was $£ 4,840,695$ (source: Industries Review Team (2003), p. 96). 
professionals are ready to go home. Normal opening hours for the workshops would also make it imperative that prison officers give up their traditional breaks and established rotas. Some reforms will entail the re-classification or even the suppression of jobs. For instance, the Industries Review Team in England proposes a 21 per cent reduction of head office staff. ${ }^{305}$ An analogous reduction would be necessary in Germany in order to convert traditionally run Prison Industries into fully centralised and independent Landesbetriebe vollzugliches Arbeitswesen. It is obvious that such reforms will meet opposition from those who feel threatened by them.

\section{Political motivations and economic conditions}

Political candidates gain votes by promising to build bigger and better prisons, not by pledging additional credits for better working conditions inside. This is how Wrage portrays the difficulty:

The goal of rehabilitation is a constitutional duty; it is non-negotiable but can only be achieved with considerable resources. We can't but notice that the political will is missing as soon as it comes to committing the necessary funds. Resources are limited and must be distributed fairly. In a time of increased unemployment and a difficult economic climate, there is little enthusiasm to be found among the electorate for spending these resources on prisoners. 306

Organisational convenience, professional interests and political opportunism all contribute to slowing down necessary reforms. But the situation is not hopeless. A dramatic event can sometimes overcome opposition, like the prison riots of 1990 in England. Elsewhere, determination and dialogue can bring results, as is the case for the German Landesbetriebe. It seems to me that the reforms proposed by the Industries Review Team have a better chance than most to be implemented, because the Team wisely appointed a powerful body, the Industries Management Board, to make sure that the propositions get carried out. In short, there are strategies to overcome resistances. If every country tried solutions that worked out for its neighbours, this might be a first step in the right direction.

305 Industries Review Team (2003), p. 40.

306 Wrage (1997), NK 4, p. 14-19. 


\section{Conclusion}

The French reports quoted at the beginning of this study are right: prison labour is in crisis, mainly for three reasons:

1) It does little for the professional rehabilitation of inmates. European statistics show that fewer than $20 \%$ of ex-prisoners can be expected to hold a steady job a year after their release, and that those who will are the people who worked regularly before serving their sentence.

2) The low employment rate of prisoners - below 50\% in Germany, below $40 \%$ in France and England - jeopardizes not only the rehabilitative function of work but also its occupational and security aspect.

3) Prison business, prosperous thirty odd years ago, is now in trouble.

Several commissions have studied the problem, but there is little sign of improvement. On the contrary, job rates are declining, and Prison Industries are becoming a greater financial liability. Some of the reasons have to do with societal changes over which prison administrations have little control, such as a different perception of the value of work. For instance, thirty years ago, it would have been inconceivable that inmates should remain idle; today, this is accepted as normal. Globalisation dealt a severe blow to Prison Industries, which can no longer match the productivity of emerging countries or meet the required levels of reactivity and flexibility. Finally, a heightened feeling of insecurity, and the ensuing intolerance towards crime have led to a sizable increase in the number of inmates that cannot be matched by a corresponding growth of jobs.

Other reasons for the crisis are linked to the numerous constraints Prison Industries have to contend with. Prisons are often far from industrial centres, and many do not have satisfactory workshop areas and are under-equipped. Efficient work suffers from the restrictions imposed by prison routine: controls, searches, short working hours and the frequent turnover of workers. Other problems are linked to an under-qualified and unmotivated workforce, and organisational inefficiencies that would be fatal to any outside firm.

These difficulties are common to all three countries, but because England started renewing its prisons well before its neighbours it can boast better workshop facilities. Commercial know-how is greater in German prisons than in the other two countries. Only France seems to accumulate handicaps. Its Régie suffers from the 
same structural problems as English Prison Industries, but French prisons are more vulnerable to the effects of globalisation as they depend up to $90 \%$ on outside contracts for their workshops.

If productive work faces difficulties, so do the inmates. Their answers to the questionnaire leave little doubt that for most a job in prison is a top priority, not only for the income it provides but also because it lends meaning to the time spent inside and gives them hope for the future. But prison labour does not live up to their expectations because:

1. Current employment and training rate can no longer guarantee a place for each inmate that requests one. Only $35.2 \%$ of inmates in France, ${ }^{307}$ $48.5 \%$ in Bavaria, $50.8 \%$ in Hesse, ${ }^{308}$ and less than $40 \%$ in England ${ }^{309}$ have a job or are in training.

2. The low level of pay does little for the rehabilitation of inmates. French prisoners are relatively better paid than their English or German counterparts, earning on average $€ 19.40$ per day for industrial work and $€ 7.40$ in the domestic sector, but this just allows them to buy basic consumer items in prison. It is not enough to help them take care of their families, pay their debts, and leave prison with enough money to get through the first month. Despite a substantial pay increase in 2001, German inmates employed in industrial work still earn less than the French (€10.56 per day for semi-qualified industrial work). This is hardly enough to "instil in them a minimal consciousness that work is a useful basis for life," as required by the Constitutional Court. The position of English prisoners is worse since the basic industrial daily wage paid by Prison Industries is $£ 1.60(€ 2.40)$.

3. Too many jobs are monotonous and lead to no useful qualification. German inmates are given the best opportunities, and Prison Industry workshops, responsible for about half of industrial employment, offer a good number of skilled jobs and various training options. In England, budgetary pressures have forced Prison Industries to reduce the range of manufacturing sectors to one or two per prison. The production process is usually split into a sequence of small operations with inmates repeating the same steps over and over again. On the positive side, most workshops of-

307 Source: Administration pénitentiaire française, 2005.

308 These rates are for 2001. They most likely are lower today, as the number of jobs and training places has not been able to keep pace with the increase in the prison population.

309 It is more difficult to give a precise rate for England, as the statistics combine the different activities under the umbrella of "purposeful activities", without differentiating between work, training, education and addressing offending behaviour. The rate is however closer to the French figures than to German ones. 
fer training that leads to national qualifications (NVQs). As Prison Industries can no longer provide enough jobs for the growing population, prisons have to turn more and more to menial contract work. In France, prison run industries play a minor role, and the proportion of semi-skilled or skilled industrial jobs is lower than in the other two countries, at most 10 per cent.

4. The legal status of working inmates is far removed from that of regular employees. Actually, it is quite close to that of illegal immigrant workers, who also work outside the network of rights and protections afforded by a contract of employment and are paid inferior wages. But the situation is improving. France has gone further than the other two countries in extending employment rights to its prisoners. Since 1987 work is no longer mandatory, and the social insurance scheme is virtually the same as for free labour, with the exception of unemployment benefits. Despite these advances, the difference in legal status remains great. Not only are inmates deprived of most individual and collective rights associated with an employment contract, they are also barred from access to labour tribunals in case of conflict with their employers. Administrative courts, their only alternative, have so far shown little willingness to take up prisoners' complaints in labour matters.

By 1976 Germany had adopted a modern prison law centred on the concept of rehabilitation. Work remains mandatory, but inmate workers are granted most of the social protections associated with an employment contract, apart from the pension scheme. If they are laid off on technical or economic grounds, they keep 33\% of their salary. In case of an accident at work, the insurance pays $80 \%$ of the salary for the days missed, which is not the case in France. After one year of work, inmates have the right to three weeks paid "vacation", also unheard of in France. Access to the courts is difficult but not impossible. Despite these positive elements, there are the same shortcomings regarding individual and collective rights as in France.

As far as England is concerned, the notion of "legal status" is hardly applicable, as most labour regulations have yet to penetrate the prison walls. Inmate workers can claim no rights other than to be paid, and are granted no part in the social protection network. Access to the courts in labour matters is virtually non-existent. Even in the case of a work accident, it is the injured inmate who has to prove that the Prison Service has not fulfilled its duty of care, a practice that was abandoned more than a hundred years ago in the other two countries. Yet English prisoners complain little about their lack of rights. This may be because internal regulations concerning hiring, firing and disciplinary procedures are often exemplary and protect the "rights" of inmates just as well, if not better than do French or German laws. The lack of a tribunal in labour matters is compensated by the fact that in- 
mates can bring their complaints before two other bodies: the Independent Monitoring Board and the Prison Ombudsman, even if theses two instances can only state their opinion and have no power to rectify arbitrary decisions.

The economic performance of workshops has been steadily declining. Once hidden subsidies are removed, Prison Industries are a liability rather than an asset. With the exception of Bavaria, all show a loss. Many contracts with external firms do little to improve the situation; they barely cover the costs to the prisons.

But not all is negative. Each country has created centres of excellence, where work gives scope for personal development and opens prospects for the future. Everywhere, efforts are made to improve the professional outlook of inmates. England adopted a holistic approach to meet the needs of its prison population by combining work with professional training, basic education and behavioural therapy. Germany places the emphasis on skilled jobs, efficiently run workshops, and longterm training. France believes in paying better wages, and is one of the few countries in Europe where work is no longer mandatory. Even on the economic side, not all is bleak, with several workshops proving that Prison Industries can be competitive and profitable.

Disillusionment with prison labour may have much to do with false expectations. Work is not a universal remedy. It can neither guarantee a job to all who leave prison nor prevent a certain number from re-offending. Neither can it solve the economic problems of the Prison Service. But it can create workplaces where inmates are treated like ordinary workers, and where the quality of the job and the level of pay are such that they want to do their best. If work can achieve this, it will have done much for their rehabilitation. What is needed is the determination to change established hierarchical relationships, reduce the excessive interference of security measures, and give Prison Industries appropriate structures. This cannot be brought about without the support of the legislature, and it will have a price. But it is worth it. 


\section{Bibliography}

ADMINISTRATION PÉNITENTIAIRE, Rapport annuel d'activité 1997-2002. Paris, La Documentation Française, 1999-2003.

ALBRECHT H.-J., Kriminell weil arbeitslos? Arbeitslos weil kriminell? Zeitschrift für Bewährungshilfe Nr. 2, 1988, p. 133-147.

ALBRECHT H.-J./DÜNKEL F. et al. (eds.), Internationale Perspektiven in Kriminologie und Strafrecht. Festschrift für Günther Kaiser zum 70.Geburtstag. Berlin, 1998.

ASSEMBLÉE NATIONALE, Rapport fait au nom de la commission d'enquête sur la situation dans les prisons françaises, sous la présidence de M. Louis Mermaz. Paris, Les documents d'information de l'Assemblée nationale, 2000.

AUVERGNON Ph./GUILLEMAIN C., Travail pénitentiaire en question. Paris, 2006.

BUNDESARBEITSGEMEINSCHAFT FÜR STRAFFÄLLIGENHILFE (BAG-S), Tarifgerechte Entlohnung für Inhaftierte. ZfStVo No. 3, 1993, p.174-180.

BAREL Y., Le Grand Intégrateur, Connexions ARIP (56), 1990, p.85-100.

BAYERISCHES STAATSMINISTERIUM DER JUSTIZ, Ergebnisse der Arbeitsverwaltung der Justizvollzugsanstalten im Haushaltsjahr1997-2001. München, 1998-2002.

BAYERISCHES STAATSMINISTERIUM DER JUSTIZ, Justizvollzug in Bayern, Übersicht (Stand: Mai 2002). München, 1997, 1998, 1999, 2000, 2001,2002.

DE BOOR W./FrISCH W./RODE I. (eds.), Resozialisierung, Utopie oder Chance ? Schriftenreihe des Instituts für Konfliktforschung, Heft 16, 2. Auflage, 1999.

BOULOC B., Pénologie. Paris, 1991.

BRIDGES A., Increasing the Employability of Offenders: an Inquiry into Probation Service Effectiveness. Oxford, Centre for Criminological Research, 1998.

BRITZ G. (1999), Leistungsgerechtes Arbeitsentgelt für Strafgefangene? Zeitschrift für Strafvollzug Nr.4, 1999, p.195-203.

BURNS, G., A Perspective on Policy and Practice in the Reintegration of Offenders. European Journal on Criminal Policy and Research, vol. 6, 1998, p. 171-183.

CALLIES R.P., Strafvollzugsrecht, 3. Auflage. München, 1992.

CALLIES R.P./MUELLER-DIETZ H. (2000), Strafvollzugsgesetz. Beck'sche Kurzkommentare, Band 19. München, 2000.

CASTEL R., La Métamorphose de la question sociale. Paris, 1995.

CÉRÉ J.-P., L'Avancée de la judiciarisation de l'application des peines avec la loi N. 2000516 du 15 juin 2000. Revue pénitentiaire et de droit pénal, Nr. 4, 2000, p. 555-562.

CÉRÉ J.-P., Droit disciplinaire en prison. Paris, 2001. 
CHIEF INSPECTOR OF PRISONS (HM), Report on an Unannounced Full Inspection of HMP Featherstone, 26-30 Jan. 1998. London, Home Office, 1999.

CHIEF INSPECTOR OF PRISONS (HM), Report of an Unannounced Follow-up Inspection of HMP Featherstone, 5-6 April 2000. London, Home Office, 2001.

CHIEF INSPECTOR OF PRISONS (HM), Report of an Unannounced FollowupInspection of HMP Frankland, 5-7 Feb. 2001. London, Home Office, 2002.

CHIEF INSPECTOR OF PRISONS (HM), Report of an Announced Inspection of HMP Swaleside, 15-19 July 2002. London, Home Office, 2003.

CHIEF INSPECTOR OF PRISONS (HM), Annual Report 2005-2006. London, Home Office, 2007.

COHEN S., Visions of Social Control. Cambridge, 1985.

COMBESSIE Ph., Sociologie de la prison. Paris, 2000.

CONSEIL DE L'EUROPE, Recommandation du Comité des Ministres aux États membres : Les nouvelles règles pénitentiaires, Strasbourg, 2006.

CONSEIL ÉCONOMIQUE ET SOCIAL, Rapport présenté par D. Decisier. Les Conditions de la réinsertion socio-professionnelle des détenus en France. Paris, Journal Officiel, 2005. COUR DES COMPTES, Garde et réinsertion. La gestion des prisons. Paris, PUF, 2006.

CREMER-SCHÄFER H. (ed.), Im Namen de Volkes? Strafvollzug und Haftbedingungen in einem freien Land. Idastein, 1992.

CROW I., RICHARDSON P., RIDDINGTON C., SIMON F., Unemployment, Crime and Offenders. London, 1989.

DANTI-JUAN M., Les droits sociaux des détenus. In: PRADEL J. (ed.), La Condition juridique du détenu. Paris, 1993, p. 99-113.

DANTI-JUAN M., L'absence de contrat de travail dans l'univers pénitentiaire. Revue pénitentiaire et de droit pénal, 1997, p.127-135.

DE SCHUTTER O./KAMINSKI D. (eds.), L'Institution du droit pénitentiaire: enjeux de la reconnaissance de droits aux détenus. Paris, L.G.D.J, 2002.

DIRECTION DE L'ADMINISTRATION PÉNITENTIAIRE, La Modernisation du service général. Paris, Ministère de la Justice, 2002.

DU MENIL B., Die Resozialisierungsidee im Strafvollzug. Bestandsaufnahme und Reformanregungen hinsichtlich der Ausgestaltung der Vollzugsgrundsätze der Paragraph 3 StVollzG. Berlin, VVF, 1994.

DÜNKEL F. (1999), Germany. In: van Zyl Smit D./Dünkel F. (eds.), Prison Labour: Salvation or Slavery. Darthmouth, Aldershot UK, 1999, p. 77-103.

DÜNKEL F., La position en droit des détenus et les possibilités de contrôle légal dans le système pénitentiaire en Allemagne. In: Céré, J.P. (ed.), Panorama européen de la prison. Paris, 2002, p. 215-251.

DÜNKEL F./SNACKEN S. 2000, Strafvollzug in Europa. Neue Kriminalpolitik 4, 2000, p. 31-37. 
DÜNKEL F./VAN ZYL SMIT D. Die Behandlung von Gefangenen mit langen Haftstrafen und Ausgestaltung des Langstrafenvollzugs im internationalen Vergleich. In: MüllerDietz H./Walter M. (eds.), Strafvollzug in den 90er Jahren, Festgabe für Karl Peter Rotthaus, Centaurus, Pfaffenweiler,1995, p.115-137.

DÜNKEL F./VAN ZYL SMIT D., Arbeit im Strafvollzug - Ein Internationaler Vergleich. In: Albrecht H.-J./Dünkel F. et al., (eds.), Internationale Perspektiven in Kriminologie und Strafrecht. Festschrift für Günther Kaiser zum 70. Geburtstag, p. 1161-1199. Berlin, 1998.

ESCHKE D., Mängel im Rechtsschutz gegen Strafvollstreckungs- und Strafvollzugsmassnahmen. Heidelberg, 1993.

FAUGERON C., Des faveurs au droit : une évolution difficile ? État de la question en France. In: Collectif, Position en droit et droit de plainte du détenu. Bruxelles, 1997, p. $37-49$.

FAVARD J., Les Prisons. Paris, 1997.

FEEST J., Imprisonment and Prisoners' Work: Normalisation or Less Eligibility? Punishment \& Society, vol.1, 1999, p. 99-108.

FEUERHELM W./SCHWIND H.-D./BOCK M. (eds.), Festschrift für Alexander Böhm zum 70. Geburtstag am 14. Juni 1999. Berlin and New York, 1999.

FLETCHER R./WOODHILL D. et al., Building Bridges from Offending into Employment. York, Rowntree Trust, 1998.

FOUCAULT M., Surveiller et punir : naissance de la prison. Paris, 1975.

FOWLES A.J., Prisoners' Rights in England and the Unites States. Aldershot, 1989.

FULTON R., Workshop Expansion: Towards Full Employment. Report of the project team set up by P.E.S. Croydon. London, 1996.

FULTON R./SMARTT U., Are German Prison Industries really so much Better than Ours? Prison Service Journal, No.103, 1996, p. 2-5.

GARLAND D., Les Contradiction de la "société punitive" : le cas Britannique. Actes de la recherche en sciences sociales, 124, 1998, p. 49-67.

GEARTY C., The Prisons and the Courts. In : Muncie, J./Sparks R., Imprisonment: European Perspectives, London, Harvester Wheatsheaf, 1991, p. 219-243.

GIUDICELLI-DELAGE G./MASSÉ M., "Rapport introductif".In: PRADEL J. (ed.), La Condition juridique du détenu. Paris, 1993, p. 11-24.

GIUDICELLI-DELAGE G./MASSÉ M., Travail pénitentiaire : absence de contrat de travail. Droit social, no.4, 1997, p. 344-346.

GOFFMAN E., Asylums. London, 1961.

GUILBAUD F., Le Travail pénitentiaire. Une étude de sociologie du travail. Laboratoire Genre, Travail et Mobilités, C.N.R.S./Université Paris X-Nanterre et Paris VIII, 2006.

GUILLONNEAU M./KENSEY A., Les à-coups : étude statistique des agression contre le personnel de surveillance à partir de 376 rapports d'incident. Paris, Direction de l'administration pénitentiaire, Travaux et Documents no.53, 1998.

HAGEMANN O., Gleiche Arbeit, gleicher Lohn. NK, Nr.4, 1995, p. 21-24. 
HAGEMANN O., Leistungsgerechte Entlohnung im Strafvollzug: das Hamburger Modell. Monatsschrift für Kriminologie und Strafrechtsreform, 78. Jahrgang, Nr. 6, 1995, p. 341-351.

HAMMERSCHICK W., Arbeit im Strafvollzug - Rechtslage und Realität im europäischen Vergleich. In: Hammerschick W./Pilgram A. (eds.), Arbeitsmarkt, Strafvollzug und Gefangenenarbeit. Jahrbuch für Rechts- und Kriminalsoziologie. Baden-Baden, 1997, p. 71- 85 .

HAMMERSCHICK W./PILGRAM A./RIESENFELDER A., Zu den Erwerbsbiographien und Verurteilungskarrieren Strafgefangener und Strafentlassener, rekonstruiert anhand von Sozialversicherungs- und Strafregisterdaten. In: Hammerschick W.; Pilgram A. (ed.), Arbeitsmarkt, Strafvollzug und Gefangenenarbeit. Jahrbuch für Rechts- und Kriminalsoziologie. Baden-Baden, 1997, p. 155-187.

HARDES M., Leistungen für Gefangene bei Arbeitslosigkeit. ZfStrVo, Nr. 3, 2001, p. 139-141.

HEDDERMAN C./TURNBULL P./WEBSTER R., Building Bridges from Offending into Employment. Prison Service Journal, No. 134, 2002, p. 42-44.

HERZOG-EVANS, M., Le droit pénitentiaire : un droit faible au service du contrôle des détenus ? In: C. Faugeron/A. Chauvenet et al., (eds.), Approches de la prison. Bruxelles, De Boeck Université, 1996, p. 273-296.

HERZOG-EVANS M., La Gestion du comportement du détenu. Essai de droit pénitentiaire. Paris, 1998.

HERZOG-EVANS M., La révolution pénitentiaire française. In: De Schutter O./Kaminski D. (eds.), L'Institution du droit pénitentiaire : enjeux de la reconnaissance de droits aux détenus. Paris, L.G.D.J., 2002, p. 17-41.

HESSISCHES MINISTERIUM DER JUSTIZ, Abteilung Strafvollzug Statistiken zum Arbeitswesen. Wiesbaden, 1997-2002.

HESSISCHES MINISTERIUM DER JUSTIZ, Abteilung Strafvollzug, Abschlussbericht der Arbeitsgruppe "Neuorganisation des Arbeitswesens". Wiesbaden, Feb. 2002.

HESSISCHES MINISTERIUM DER JUSTIZ, Abteilung Strafvollzug, Abschlussbericht der Arbeitsgruppe "Erhöhung der Beschäftigungsquote". Wiesbaden, Sept. 2002.

HOOD R./SHUTE S., Parole in Transition: Evaluating the Impact and Effects of Changes in the Parole System. Phase One. Oxford, Centre for Criminological Research, Oxuniprint, 1994.

HOOD R./SHUTE S., Paroling with New Criteria: Evaluating the Impact and Effects of Changes in the Parole System. Phase Two. Oxford, Centre for Criminological Research, 1995.

HOOD R. and SHUTE S., The Parole System at Work: a study of risk-based decisionmaking. Home Office Research Study 202. London, Home Office, 2000.

INDUSTRIES REVIEW TEAM, REGIME SERVICE GROUP (report by) Prison Service HQ Review Programme: Prison Industries. London, Home Office, 2003.

INSEE, L'Histoire familiale des hommes détenus, Synthèse $n^{\circ}$ 59, 2002. 
JEHLE J.M., Arbeit und Entlohnung von Strafgefangenen. ZfStrVo Nr. 5, 1994, p. 259267.

KAMANN U. (1999), Die Bürokratisierung des Strafvollzuges als Hemmschwelle der Resozialisierung. In: de Boor W./Frisch W./Rode I. (eds.), Resozialisierung, Utopie oder Chance. Schriftenreihe des Instituts für Konfliktforschung, Heft 16, 1995, p. 61-77.

KENSEY A./TOURNIER P., Placement à l'extérieur, semi-liberté, libération conditionnelle. Des aménagements d'exception. Paris, Ministère de la Justice, 2000.

KÖHNE M., Die "allgemeinen Lebensverhältnisse" im Angleichungsgrundsatz des StVollzG. Zeitschrift für Bewährungshilfe 3/2003, p. 250-254.

KURY H., Zum Stand der Behandlungsforschung oder : vom nothing works zum something works. In: Feuerhelm W. et al. (eds.), Festschrift für Alexander Böhm zum 70. Geburtstag am 14. Juni 1999. Berlin, 1999, p. 251-274.

LE CAISNE L., Prison : une ethnologue en centrale. Paris, 2000.

LEECH M., The Prisons Handbook. Manchester, Prisons.Org. UK Ltd, 2006.

LEGGE K., Work in Prison: The Process of Inversion. British Journal of Criminology, Vol. 18, January 1978, p. 6-22.

LESTING W., Normalisierung im Strafvollzug: Potential und Grenzen. Pfaffenweiler, 1988.

LÉVY R./ZANDER H., Introduction à Rusche et Kirchheimer, Peine et structure sociale. Paris, Les éditions du Cerf, 1994, p. 9-72.

LIEBLING A., Prisons and their Moral Performance. Oxford, OUP, 2004.

LIEBLING A./MARUNA S., The Effects of Imprisonment. Willan, 2005.

LIVINGSTONE S./OWEN T. et al. Prison Law, Oxford, OUP, 2003.

LOHMANN H.C., Arbeit und Arbeitsentlohnung des Strafgefangenen. Frankfurt a.M., 2002.

LORIDANT, P., Rapport d'information fait au nom de la commission des finances, du contrôle budgétaire et des comptes économiques de la Nation sur la mission de contrôle sur le compte de commerce 904-11 de la Régie Industrielle des Etablissements Pénitentiaires (RIEP). Sénat, $N^{\circ} 330,2002$.

LORIOL M., Qu'est-ce que l'insertion ? Entre pratiques institutionnelles et représentations sociales. Paris, 1999.

LORVELLEC S., Travail et peine. In: Supiot A. (ed.) Le Travail en perspectives. Paris, L.G.D.J., 1998, p. 247-263.

LOUCKS N., Prison Rules, a Working Guide. London, Prison Reform Trust, 2000.

LU Y.-C., Rechtsstellung und Rechtsschutz der Strafgefangenen. Inaugural-Dissertation, Juristische Fakultät der Eberhard-Karls-Universität, Tübingen, 1998.

LÜCKERMANN C., "§43,200 StVollzG". ZfStrVo, Nr. 2, 2002, p. 121-122.

MAETZE W., Berufseinstieg statt 'Kriminelle Karriere'. ZfStrVo, Nr. 5, 2001, p. 289-291.

MAIR G./MAY C., Offenders on Probation, Home Office Research Study 167, 1997. 
MARCHETTI, A.M., Pauvretés en prison. Ramonville, 1997.

MARCHETTI, A.M., Le travail en détention : un révélateur de la condition carcérale. Paris, Les Cahiers de la sécurité interne, 31, 1998, p. 183-193.

MATT E., Das Verbundprojekt "Chance" in Bremen: Konzeption und Praxis. ZfStrVo Nr.2, 2003, p. 81-88.

MATTHEWS R./FRANCIS P., Prisons 2000, An International Perspective on the Current State and Future of Imprisonment, London, 1996.

MÉDA D., Le Travail, une valeur en voie de disparition, Paris, 1995.

MELOSSI D., Georg Rusche and Otto Kirchheimer: "Punishment and Social Structure". Crime and Social Justice, Spring-Summer 1978, p. 73-85.

MINISTÈRE DE LA JUSTICE, DIRECTION DE L'ADMINISTRATION PÉNITENTIAIRE, La Modernisation du service général. Paris, 2002.

MÜLLER-DIETZ H., Die Bedeutung der Arbeit im Rahmen des Behandlungsvollzugs. ZfStrVo, Nr.3, 1973, p. 125-135.

NEU A., Betriebswirtschaftliche und volkswirtschaftliche Aspekte einer tariforientierten Gefangenenentlohnung. ZfStrVo Nr. 3, 1995, p. 149- 161.

NEU A., Wirtschaftsfaktor : Gefängnis. NK, Nr. 2, 1995, p. 35-40.

NEU A., Produktivität der Gefängnisarbeit: eingemauert auf bescheidenem Niveau? In: Hammerschick W.; Pilgram A. (eds.), Arbeitsmarkt, Strafvollzug und Gefangenenarbeit. Jahrbuch für Rechts- und Kriminalsoziologie. Baden-Baden, 1997, p. 97- 111.

NEU A., Der Gesetzgeber bleibt gefragt. NK, 1998, Nr. 4, p. 16-19.

NEU A., Den verfassungsrechtlichen Vorgaben knapp entsprochen.NK, Nr. 2, 2001, p. $22-$ 26.

O'BRIEN P., Correction ou châtiment. Paris, PUF, 1988.

PÉCHILlON E./HERZOG-EVANS M. (eds.), Le Droit de l'exécution des peines, Problème et enjeux d'une discipline juridique en formation. Paris. GIP "Mission recherche Droit et justice", 2003.

PENDON, M., Europäische Dimensionen in der Berufsausbildung im Strafvollzug. ZfStrVo, Nr. 6, 1996, p. 337-341.

PERROT M. (1980), L'Impossible prison, Paris, Seuil, 1980.

PILGRAM A., Freiheitsstrafe als Fangnetz für Arme. NK, Nr. 4, 1998, p.21-26.

PILGRAM A., Von den Schwierigkeiten, im Strafvollzug Normalität herzustellen.NK, Nr. 2, 1995, p. 41-44.

PILGRAM A., Voraussetzungen, Perzeption und Folgen der Österreichischen Vollzugsnovelle 1993. In: Hammerschick W./Pilgram A.(eds.) Arbeitsmarkt, Strafvollzug und Gefangenenarbeit. Jahrbuch für Rechts- und Kriminalsoziologie, Nomos, 1997, p. 49-68.

PLAYER E./ JENKINS M. (eds.), Prisons after Woolf: Reform through Riot. London and New York, 1994.

PÖRSKEN A., Neuregelung der Gefangenenentlohnung. NK, Nr. 1, 2001, p. 5-6. 
PRADEL J. (1993), Les recours ouverts au détenu contre les décisions relatives à l'exécution de sa peine ; le cas de la France et du Canada. In: Pradel J. (ed.), La Condition juridique du détenu. Paris, 1993, p. 233-244.

PREUSKER H., Zur Situation der Gefängnisarbeit. ZfStrVo Nr. 2, 1988, p. 92-95.

PREUSKER H., Reform-Entzug? NK, Nr. 2, 1997, p. 34-36.

PROJEKTVERBAND "CHANCE", Systematischen Betreuung von Straffälligen mit dem Ziel der Wiedereingliederung in die Gesellschaft. Bremen, Justiz-Dienstleistungen, 2002 .

RADKE H., Die Zukunft der Arbeitsentlohnung von Strafgefangenen. ZfStrVo, Nr. 1, 2001, p. 4-14.

REICHARDT H., Recht auf Arbeit für Strafgefangene. Ein Beitrag Zum subjektiven öffentlichen Recht. Frankfurt, 1999.

RICHARDSON G., From Rights to Expectations. In: Player E. and Jenkins M. (eds.), Prisons after Woolf. Reform through Riot. London and New York, Routledge, 1994, p. 78-96.

RIFKIN J., The End of Work: the Decline of the Global Labour Force and the Dawn of the Post-Market Era. New York, 1995.

ROSENTHAL M., Arbeitslohn im Strafvollzug. NK, Nr. 2, 1998, p.12-16.

RUSCHE G., Arbeitsmarkt und Strafvollzug: Gedanken zur Soziologie der Strafjustiz. Frankfurt, Zeitschrift für Sozialjustiz, II/1933, p. 63-78.

RUSCHE G./KIRCHHEIMER O., Peine et structure sociale. Texte présenté par Lévy R. et Zander H., Paris, 1994.

SAMPSON R.J./LAUB J.H., Crime in the Making: Pathways and Turning Points Through Life. Cambridge, MA, 1993.

SCHRIEVER W., Praktische Erfahrungen mit dem neuen § 43 StVollzG. ZfStrVo, 2002, p. 86-89.

SCHÜLER-SPRINGORUM, Angemessene Anerkennung als Arbeitsentgelt: Das Bundesverfassungsgericht zur Arbeit im Strafvollzug. In: Feuerhelm W. et al. (ed.), Festschrift für Alexander Böhm zum 70. Geburtstag am 14. Juni 1999. Berlin, 1999, p.219-232.

SÉNAT, LES RAPPORTS de (Président : J.J. Hyest; Rapporteur : G.P. Cabanel), Prisons : une humiliation pour la République. Paris, 2000.

SHEA E., Le Travail pénitentiaire : un défi européen. Paris, 2006

SIGEL W., Auf dem Weg zum "Landesbetrieb VAW Baden-Württemberg". Unternehmerische Möglichkeiten in den Gefängnisbetrieben. ZfStrVo, Nr. 6, 1996, p. 340-341.

SIGEL W., Gefangenenarbeit und berufliche Förderung im baden-württembergischen Justizvollzug. ZfStrVo, Nr. 2, 1993, p. 85-89.

SIMON F., Prisoner's Work and Vocational Training. London, 1999.

SMARTT U., Industrial Prisons. Prison Service Journal, No.106, 1996, p. 2-8.

SMARTT U./VAGG J., Prison Works? Prison Service Journal, No.120, 1998, p. 7-12. 
SMARTT U./VAGG J., What Works in Prison Industries? 'Still no Change' or 'the Best Opportunity for Change in Over a Decade'? Prison Service Journal, No. 154, 2004, p. 31-35.

SNACKEN S., Normalisation" dans les prisons : concept et défis. L'exemple de l'Avant-projet de loi pénitentiaire belge. In: De Schutter, O./Kaminski D.(eds.), L'Institution du droit pénitentiaire. Enjeux de la reconnaissance de droits aux détenus. Paris, L.G.D.J, 2002, p. 133-152.

SOCIAL EXCLUSION UNIT, Reducing Re-offending by Ex-prisoners. London, Office of the Deputy Prime Minister, 2002.

SPARKS R., Penal austerity: the doctrine of less eligibility reborn? In: Matthews R./Francis P., Prisons 2000.London, McMillan, 1996.

SPARKS R./BOTTOMS A./HAY W. (eds.), Prisons and the Problem of Order. Oxford, 1996.

SUPIOT A. (ed.), Le Travail en perspective, Avril 96, Nantes. Actes du colloque, Librairie générale de Droit et de Jurisprudence, 1998.

TALANDIER J., La problématique travail-prison : des intentions à la peine. Economie et humanisme, no. 329, juin, 1994, p. 41-49.

TALANDIER J., Rapport présenté au nom du Conseil économique et social, Travail et prison. Paris, Journal Officiel, 1987.

TARDY V., Le travail en milieu carcéral : essai d'un bilan. Revue pénitentiaire et de droit pénal, 1997, p. 227- 235.

TREVERTON-JONES G.D., Imprisonment: The Legal Status and Rights of Prisoners. London, 1989.

ULLENBRUCH T., Neuregelung des Arbeitsentgelts für Strafgefangene - Sand in die Augen des BverfG? Zeitschrift für Rechtspolitik, Heft 5, 2000, p.177-182.

VAGG I./SMARTT U. (1999), "England and Wales". In: van Zyl Smit D./Dünkel F. (eds.) Prison Labour: Salvation or Slavery? Aldershot, 1999, p. 37-76.

VAN ZYL SMIT D./ DÜNKEL F. (eds.), Prison Labour: Salvation or Slavery? Aldershot, 1999.

VASSEUR V., Médecin-Chef à la prison de la Santé. Le cherche midi éditeur, Paris, 2000.

WEBB B./WEBB S., English Prisons und Local Government. 1922.

WEBER H.-M., "Moderner Strafvollzug - Wohin ? Eine Bestandsaufnahme zur Rechtfertigungsproblematik von Vollzugszielen". In: Cremer-Schäfer H. (ed.), Im Namen des Volkes? Idstein, 1992, p. 35-50.

WEBER H.-M., Gefängnis und freier Markt. NK, Nr. 3, 2000, p. 17-21.

WIRTH W., Prävention durch Wiedereingliederung in den Arbeitsmarkt: Cui bono? In: Kawamura G./Helms U. (eds.), Straffälligenhilfe als Prävention ? Freiburg, 1998, p. 5575.

WOHLGEMUTH R. (1999), Der Vollzug kann mehr zu seiner Finanzierung beitragen. ZfStrVo, Nr. 4, 1999, p. 219-222. 
WOOLF, H. and TUMIM S., Prison Disturbances April 1990: Report of an Inquiry. Cm1456, London, HMSO, 1991.

WRAGE N., Resozialisierung und Ressourcen.NK, Nr. 4, 1997, p. 14-19.

ZAKINE I., Les droits sociaux du détenu. Revue pénitentiaire et de droit pénal, 1982, p. 267-282. 


\section{List of Tables}

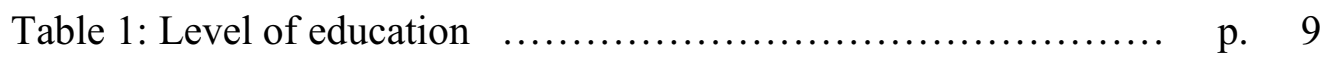

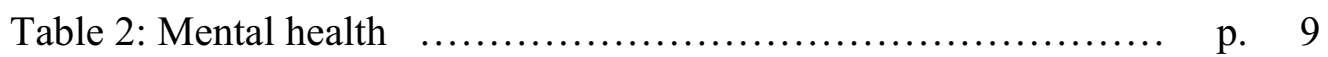

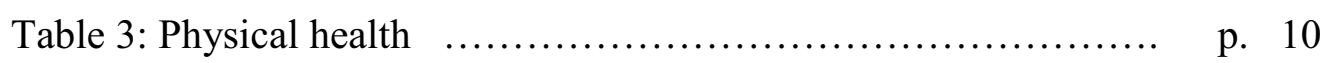

Table 4: Factors contributing to social exclusion $\ldots \ldots \ldots \ldots \ldots \ldots \ldots$ p. 10

Table 5: Employment status of inmates before and after their prison term ................................... p. 12

Table 6: English Prison Industries: budget forecast for $2003 / 2004$.... p. 37

Table 7: Contribution of prison labour to the cost of imprisonment in Germany .......................... p. 38

Table 8: Inmates' preferred option in case of a disagreement at work ................................................................... p. 50

Table 9: Social benefits .................................... p. 60

Table 10: Paid activities at the maison centrale of Ensisheim $\ldots \ldots \ldots$ p. 67

Table 11: Paid activities at the maison centrale of Poissy $\ldots . . . \ldots \ldots$ p. 73

Table 12: Paid activities at the centre de detention of Montmédy ...... p. 79

Table 13: Remunerated activities at the JVA Schwalmstadt .......... p. 84

Table 14: Remunerated activities at JVA Straubing $\ldots \ldots \ldots \ldots \ldots \ldots$ p. 90

Table 15: Remunerated activities at JVA Kaisheim ............... p. 97

Table 16: Remunerated activities at HMP Frankland ............... p. 104

Table 17: Remunerated activities at HMP Featherstone $\ldots \ldots \ldots \ldots . . . . . \quad$ p. 112

Table 18: Annual Sales Engineering, HMP Featherstone $\quad . . . . . . . . \quad$ p. 114

Table 19: Remunerated activities at HMP Swaleside ............... p. 120

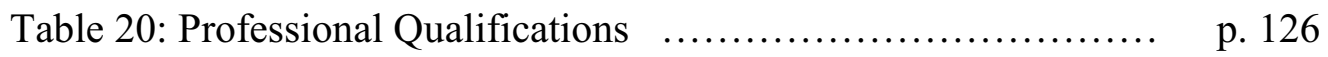

Table 21: Reasons for working ............................... p. 127

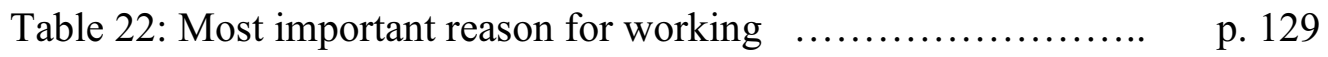

Table 23: Three reasons for working, country by country ......... p. 129

Table 24: Reasons given for having learnt little or nothing while working or in training $\ldots \ldots \ldots \ldots \ldots \ldots \ldots . . . . . . .134$

Table 25: Reasons why inmates are optimistic about

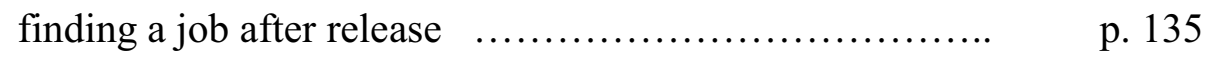

Table 26: Inmates' suggestions as to how to improve prison labour ... p. 139 


\section{Abbreviations}

\section{In English:}

Art.

Chap.

DIF-Prindus

DIS

ESS

Ed(s).

f.

HMP

Ibid.

$\mathrm{Nr}$.

NVQ

p.

PES

PFI

PSIF

In French:

al.

CPP

FARAPEJ

GENEPI

INSEE

L.

PACTE 1

PACTE 2

RIEP

SEP

SNTMP

\section{In German:}

Abs.

BewHi

BverfGE

Diss.

JVA

MSchrKrim
Article

Chapter

Directorate of Prison Industries and Farms

Directorate of Industries and Supplies

Enterprise and Supply Service

Editor(s)

following

Her Majesty's Prison

At the same place

Number

National Vocational Qualifications

Page(s)

Prison Enterprise Service

Private Finance Industries

Prison Service Industries and Farms

alinéa

Code de procédure pénale

Fédération des Associations Réflexion Action Prison et Justice

Groupement Etudiant national d'Enseignement aux Personnes Incarcérées

Institut National de la Statistique et des Etudes Economiques

Loi

Plan d'Action pour la Croissance du Travail et de l'Emploi

Plan d'Amélioration des Conditions de Travail et Emploi

Régie Industrielle de l'Emploi Pénitentiaire

Service de l'Emploi Pénitentiaire

Service National pour le Travail en Milieu Pénitentiaire

Absatz

Zeitschrift für Bewährungshilfe

Bundesverfassungsgerichtsentscheid

Dissertation

Justizvollzugsanstalt

Monatsschrift für Kriminologie und Strafrechtsreform 
NK

NStZ

SGB III

StVollzG

VAW

VV

ZfStrVo
Neue Kriminalpolitik

Neue Zeitschrift für Strafrecht

Drittes Buch Sozialgesetzbuch - Arbeitsförderung

Strafvollzugsgesetz

Landesbetriebe für vollzugliches Arbeitswesen

Verwaltungsvorschrift zum Strafvollzugsgesetz

Zeitschrift für Strafvollzug und Straffälligenhilfe 